UNIVERSIDADE DE SÃO PAULO

FACULDADE DE FILOSOFIA, LETRAS E CIÊNCIAS HUMANAS

PROGRAMA DE PÓS-GRADUAÇÃO EM SOCIOLOGIA

\title{
Fogo e ASFALTO: \\ INSUBMISSÕES, PERSECUÇÕES E FANTASMAGORIAS
}

Andrea Soledad Roca Vera

(VERSÃO CORRIGIDA)

São Paulo

2019 
Andrea Soledad Roca Vera

\section{FOGO E ASFALTO: INSUBMISSÕES, PERSECUC̣ÕES E FANTASMAGORIAS}

Tese apresentada ao Programa de PósGraduação em Sociologia da Faculdade de Filosofia, Letras e Ciências Humanas da Universidade de São Paulo, para obtenção do título de Doutora em Sociologia.

Orientação: Dr ${ }^{\mathrm{a}}$. Vera da Silva Telles

(VERSÃO CORRIGIDA)

São Paulo 2019 
Autorizo a reprodução e divulgação parcial deste trabalho, por qualquer meio convencional ou eletrônico, para fins de estudo e pesquisa, desde que citada a fonte.

Catalogação na Publicação

Serviço de Biblioteca e Documentação

Faculdade de Filosofia, Letras e Ciências Humanas da

Universidade de São Paulo

Roca Vera, Andrea Soledad.

Fogo e Asfalto: Insubmissões, Persecuções e

Fantasmagorias / Andrea Soledad Roca Vera; orientadora

Vera da Silva Telles - São Paulo, 2019.

$230 \mathrm{p}$.

Tese (Doutorado) - Faculdade de Filosofia, Letras e

Ciências

Humanas da Universidade de São Paulo. Departamento

de Sociologia. Área de concentração: Sociologia.

1. Violência Política. 2. Manifestações de Rua. 3.

Polícia. 4. Etnografia. 5. Chile. I. Telles, Vera de Silva, orient. II. Título 
E. If. ffAhE ha FACULDADE DE FILOSOFIA, LETRAS E CIÊNCIAS HUMANAS

\title{
ENTREGA DO EXEMPLAR CORRIGIDO DA DISSERTACCÃO/TESE
}

Termo de Ciência e Concordância do (a) orientador (a)

\author{
Nome do (a) aluno (a): ANDREA SOLEDAD ROCA VERA \\ Data da defesa: 24/09/2019 \\ Nome do Prof. (a) orientador (a): VERA DA SILVA TELLES
}

Nos termos da legislação vigente, declaro ESTAR CIENTE do conteúdo deste EXEMPLAR CORRIGIDO elaborado em atenção às sugestões dos membros da comissão Julgadora na sessão de defesa do trabalho, manifestando-me plenamente favorável ao seu encaminhamento e publicação no Portal Digital de Teses da USP.

São Paulo, 12/11/2019

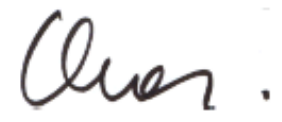

(Assinatura do (a) orientador (a) 
ROCA VERA, Andrea Soledad. Fogo e Asfalto: Insubmissões, Persecuções e Fantasmagorias / Andrea Soledad Roca Vera ; orientadora Vera da Silva Telles - São Paulo, 2019. Tese de Doutorado apresentada ao Programa de Pós-Graduação em Sociologia da Faculdade de Filosofia, Letras e Ciências Humanas, da Universidade de São Paulo, para a obtenção do título de Doutora em Sociologia.

Data de exame da tese:

$24 / 09 / 2019$

\section{Banca Examinadora:}

Prof $^{a}$. Dr ${ }^{a}$. Patrícia Birman

Prof. Dr. Edson Luis de Almeida Teles

Prof. Dr. Paulo Eduardo Arantes

Prof $^{a}$. Dr ${ }^{a}$. Vera da Silva Telles
Instituição: UERJ

Instituição: UNIFESP

Instituição: USP

Instituição: USP 
Para ti Adriana, por tu coraje y ternura 


\section{Agradecimentos}

Uma malha de encontros, despedidas, coincidências inusitadas e devires foi pletora de vida nestes mais de quatro anos de doutoramento. Mais uma vez agradeço à Universidade de São Paulo: desde o mestrado, me orgulho de ser parte das universidades públicas que ainda restam na América Latina em meio a processos de estrangulamentos da educação pública e gratuita. Em momentos infames como os atuais, não posso deixar de destacar que a minha trajetória migratória respondeu ao fato de que, aqui, no Brasil, tive mais oportunidades para me desenvolver academicamente que em meu próprio país.

Sou grata às instituições brasileiras que, generosamente, apoiaram esta pesquisa, sobretudo financeiramente: o Programa de Estudantes do Convênio de Pós-Graduação da Capes e a Fundação de Amparo à Pesquisa do Estado de São Paulo (Processo no 2015/19686-5).

Retornar em 2015 a São Paulo para iniciar este doutorado foi possível pelo convite da professora Vera Telles, minha orientadora, a quem devo gratidão pela confiança e pela liberdade com as quais construimos a nossa relação. A paixão que sempre coloca em seus trabalhos é contagiosa e inspiradora. Quero agradecer, também, ao grupo de pesquisadores marcados pelos fazeres etnográficos, que, ano a ano, se reúne entorno/junto a ela. Sou grata a Carlos Freire, Tiago Rangel, Renato Abramowicz, Régis Menvielle, Bruna Ramachiotti, Juliana Machado, Marina Mattar e Rafael Godói - pelas trocas, pelos diálogos e, claro, pelas divergências.

Da turma de doutorado, quero agradecer a Benno Alves: amigo, obrigada por me acolher na Barra Funda e pelas tantas road trip junto a Isa. A Fábio Mallart e Ricardo Campello, gracias pelas conversas, ás vezes um tanto angustiantes sobre pesquisas e vidas. A Ricardo, agradeço mais uma vez por nos incentivar na organização do seminário "Tecnologia e Controle" na FFLCH, junto a Alcides Perón, Leandro Siqueira e Claudio Altenhain.

A respeito daquele ritual de meio termo, o exame de qualificação, agradeço a Carolina Grillo e Rosana Pinheiro-Machado, pela leitura fina que fizeram dos primeiros avanços desta pesquisa.

Sempre com o apoio da FAPESP, esta minha formação doutoral teve dois momentos estadunidenses importantes: o primeiro, em junho de 2018 , 
na escola de verão do Institute for Critical Social Inquiry da The New School of Social Research. Passar alguns dias com Jean e John Comaroff foi uma chance preciosa de aprendizado. Na viagem, ainda conheci Javiera Araya, maravilhosa socióloga chilena, e Liliana Gil, pesquisadora portuguesa das gambiarras brasileiras, com quem, por voltas da vida, terminei morando em São Paulo. Obrigada Gil, por tudo.

O segundo momento foi em Austin, como Visiting Scholar da University of Texas, entre setembro de 2018 e janeiro de 2019 (FAPESP/BEPE Processo $n^{\circ}$ 2018/04357-4). Agradeço ao professor Javier Auyero, meu supervisor, por me permitir participar de seu afamado seminário de "Leituras Etnográficas", experiência catártica de busca de nossos “warrants" e "puzzles". Não posso deixar de agradecer, por extensão, a Irene Rossetto e Marcelo Paixão: gratidão pela solidariedade.

Já no Chile, quero agradecer a pesquisadora Manuela Badilla pela confiança e troca sinceras. A Nicolás Acevedo, sou grata por sua generosidade, por compartilhar experiências de vida e de pesquisa. Os dois me mostraram imagens do passado, oriundas de seus arquivos pessoais, pistas importantíssimas para algumas das ideias que elaboro nesta tese.

Nestes anos na FFLCH, tenho a felicidade de continuar agradecendo a Lucas Amaral de Oliveira e a Bruna Triana. Amigos, o meu pensamento, a minha imaginação e o meu amor prolifera ao lado de vocês. O brilho de ambos me ilumina. A Lucas, agradeço mais uma vez por ajudar na revisão desta tese.

Às amigas chilenas, meu carinho: Rebeca, Pamela, Anita, Nidia e Coté, companheiras da vida, obrigada por serem suporte emocional nos momentos felizes, assim como nos embates inesperados.

A Rodrigo Millán, amigo chileno que ganhei em São Paulo, maravilhoso historiador do urbanismo esportivo latino-americano. Junto com Valentina Martelli, foram a minha célula chilena nesta pauliceia desvairada, esta cidade que amaremos para sempre. Sou grata, também, a Rodolfo Quiroz, mais um chileno vivendo o sonho da "uspi" - gracias pelos cafezinhos.

A mi padres, Erika y Ángel, y hermanos, José y Ángel, agradezco en español. Gracias por estar cerca a la distancia. Somos familia en movimiento, cada almuerzo de reencuentro es una alegría en el corazón. Mi cariño también 
a Lastenia, mi abuela con sus 90 y tantos años quien siempre tiene una palabra de aliento.

A mi compañero, Javier: porque nos estrellamos una noche de verano y, desde aquel instante inesperado, oscilamos entre aproximación, alejamiento y fusión. Gracias por ser la piedra donde descanso y yo, tu roca.

Por último, a las y los jóvenes que protagonizan esta tesis. Gracias infinitas por compartir sus experiencias de lucha, resistencia y revuelta. 


\section{Resumo}

Este trabalho parte de uma pergunta arriscada: por que, mesmo depois de três décadas, alguns mortos continuam a ser recordados? Tal questão nos coloca do lado das fantasmagorias - e, por extensão, da política. Fogo e Asfalto é um convite a explorar a história recente chilena seguindo os rastros dos encapuchados, figura enigmática que, desde a década de 1980, assombra as ruas de Santiago. Essas figuras surgem, especialmente, em efemérides que recordam manifestantes anticapitalistas mortos na ditadura pinochetista e na pós-ditadura. Pelo anonimato e pela disposição a destruir objetos, lugares e corpos que encarnariam o Estado e o Capital, essas rebeldias são recusadas e expulsas para fora das margens da política. Nesse sentido, em vez de reduzi-los às esferas da baderna e criminalidade, interessa-me observar a resposta estatal total que suas ações geram. Arranjos de leis, táticas de policiamento, tecnologias e saberes, regimes penitenciários dedicados ao problema dessa violência - chamada pela polícia e pelo Ministério Público chileno de violência antissistema, anarquista insurrecional ou, ainda, de terrorismo. Pretendo de tal modo, indagar os excessos e as ansiedades do Estado na tentativa de combater aqueles que colocam como seu inimigo principal, justamente, o próprio Estado, atacando de forma aberta e espetacular os símbolos dominantes desse inimigo. Esta tese, resultado de uma pesquisa etnográfica de mais de 4 anos, se organiza em três capítulos. Em "Perseguições em Transição", analiso a empreitada política e afetiva empreendida na redemocratização, projeto orientado pela ideia da reconciliação nacional que, por sua vez, colocou como principal inimigo da nação a figura do terrorista de esquerda referindo-se àqueles que continuaram acreditando na violência como recurso na luta contra o capitalismo e contra a impunidade que protegeu aos perpetradores do terrorismo de Estado nos anos da ditadura. Em "Mortos, Ruas e Encapuchados", atento para as composições espaço-temporais entre corpos, artefatos e fantasmagorias que sustentam essas rebeldias minoritárias, propondo uma leitura estética desses exercícios cinéticos de recordação no presente dos jovens combatentes mortos no passado. Junto à análise das mudanças estéticas nos embates entre mascarados e polícia, interrogo a linhagem de mortos construída tanto pelos militantes como pela polícia, isto é, as tramas entre os que hoje se recusam a abraçar a máxima da paz e das formas cívicas de participação política e os que o fizeram no passado. No último capítulo, "Presxs a la kalle", exploro a experiência prisional de jovens acusados de perpetrar ataques contra os símbolos do Capital e do Estado. A partir do acompanhamento de audiências e de documentos jurídicos, analiso as materialidades e tecnologias mobilizadas como evidências que comprovariam a ideologia política dos suspeitos: DNA, confisco de livros, infiltrados da polícia no mundo off-line e online, conjunto que chamo de polícia mimética. 


\section{Abstract}

This work starts from a risky question: why, even after three decades, are some deaths still remembered? This question puts us on the side of phantasmagoria - and politics. Street and Fire is an invitation to explore Chilean recent history by following the traces of encapuchados, masked enigmatic figures that haunt the streets of Santiago since the 1980 os. These figures appear especially in ephemera that recall anti-capitalist protesters killed during the Pinochet dictatorship and in the post-dictatorship period. Because of their anonymity and drive to destroy objects, places, and bodies that symbolize Capital and the State, these dissents are rejected and pushed beyond the margins of politics. In this way, instead of reducing them to the spheres of turmoil and criminality, I am interested in observing the total state response that their actions generate. I investigate law arrangements, policing tactics, knowledges and technologies, and penitentiary regimes dedicated to the problem of this violence - which is called by the Chilean police and National Prosecutor's office as anti-system, insurrectional anarchism, or even terrorism. I thus intend to examine the excesses and anxieties of the State in its attempt to fight those who see it as their main enemy and openly and spectacularly attack the State's dominant symbols. This thesis, which results from more than 4 years of ethnographic research, is organized in three chapters. In "Persecutions in Transition," I analyze the political and affective endeavor undertaken in redemocratization. I discuss redemocratization as a project driven by the idea of national reconciliation that placed the leftist terrorist as the main enemy of the nation - referring to those who continued to believe in violence as a resource in the struggle against capitalism and against the impunity that protected the perpetrators of state terrorism during the dictatorship. In "Dead, Streets, and the Hooded Ones," I focus on the spatiotemporal compositions of bodies, artifacts, and phantasmagoria that support these minor insurgencies, proposing an aesthetic analysis of the kinetic exercises of present remembrance of young fighters killed in the past. Along with the analysis of the aesthetic changes in the clashes between the masked and the police, I examine the genealogy of the dead constructed by both the militants and the police, investigating the plots between those who refuse to embrace peacefulness and civic forms of political participation today and those who have done so in the past. In the last chapter, "Free all Political Prisoners," I explore the prison experience of young people accused of perpetrating attacks against symbols of Capital and the State. Drawing on court hearings and documents, I analyze the materialities and technologies mobilized as evidence in proving the suspects' ideology: DNA, confiscated books, and online and offline police infiltration, which I call mimetic police. 


\section{Resumen}

Este trabalho parte de una pregunta arriesgada: por qué, después de tres décadas, algunos muertos continúan siendo recordados? Esta cuestión nos coloca del lado de las fantasmagorías, y de la política. Fuego y Asfalto es una invitación a explorar la historia chilena reciente siguiendo los rastros de los encapuchados, figura enigmática que, desde la década de 1980, aparecen en las calles de Santiago. Estas figuras surgen, especialmente, en días de memória de manifestantes anticapitalistas muertos en la dictadura pinochetista y en la post-dictadura. Por el anonimato y la disposición a destruir objetos, lugares y cuerpos que encarnarían el Estado y el Capital, estas rebeldias son repudiadas y expulsadas de los márgenes de la política. En este sentido, en vez de reducirlos al campo del caos y la criminalidad, me interesa observar la respuesta estatal total que sus acciones generan. Un entramado de leyes, tácticas de policiamiento, tecnologías y saberes, regímenes penitenciarios dedicado al problema de esta violencia, llamada por la policía y por el Ministerio Público chileno de violencia anti-sistema, anarquista insurreccional e, incluso, de terrorismo. Pretende de este modo, indagar en los excesos y ansiedade del Estado en el intento de combatir a aquellos que colocan como su enemigo principal, justamente, al proprio Estado, atacando de forma directa y espectacular los símbolos dominantes de ese enemigo. Esta tese, resultado de 4 años de investigación etnográfica, se organiza en tres capítulo. En "Persecuciones en Transición", analizo el proyecto político y afectivo emprendido en la transición a la democracia, acciones y discursos orientados por la ideia de la reconciliación nacional que colocó como enemigo principal de la nación a la figura del "terrorista de izquierda", refiriéndose a aquellos que continuaram creyendo en la violencia como recurso en la lucha contra el capitalismo y contra la impunidad que protegió a los perpetradores del terrorismo de Estado en los años de la dictadura. Ya en "Muertos, Calles y Encapuchados", atento para las composiciones espacio-temporales entre cuerpos, artefactos y fantasmagorías que sustentan estas disidencias minoritarias, proponiendo una lectura estética de esos ejercicios cinético de memoria, en el presente, de jóvenes combatientes muertos en el pasado. Junto al análisis de los cambios estéticos en las escaramuzas entre encapuchados y policía, interrogo los linajes de muertos construídos por los militantes como también, por las policías, esto es, las tramas entre los que hoy rechazan abrazar el mandato de la paz y de las formas cívicas de participación política

y los que hicieron eso en el pasado. En el último capítulo, "Presxs a la kalle", exploro la experiencia prisional de jóvenes acusados de perpetrar ataques contra símbolos del Capital y del Estado. A partir del acompañamiento de audiencias y documentos judiciales, analizo las materialidades y tecnologías movilizadas como evidencias que comprobarían la ideología de los sospechosos: ADN, allanamiento de libros, infiltrador de la polícia en el mundo off-line y online, lo que llamo de policía mimética. 


\section{O fio vermelho}

Monte seu próprio arquivo: documentos oficiais e não oficiais, prédios, magias, fotografias e claro, algumas músicas. Misture. Atente para as polifonias, as discórdias e os silêncios. Desvencilhe as trajetórias de seus materiais: nos modos em que foram produzidos e imaginados. Mas, lembrese: não se trata de exegese. O que interessa é explorar os modos em que as realidades se tornam reais, as materialidades se materializam, os pensamentos chegam a ser pensados. Agora, ligue os fragmentos com a história. E se preocupe: isto não é nem um pouco fácil. Se não conseguir ligar os pontos, tente urdir nós, tecer tramas, você só terá estórias -podem ser interessantíssimas, mas não serão mais do que isso: estórias. Nesta travessia, fique experto. Se cuide do óbvio. A história não é um dado: é uma equação a ser resolvida entre ruptura e continuidade e sua constante mutação. Atente para o que escapa, o que nos envolve: escute o som ao redor. Mergulhe, não tenha medo. Adense nas ambiguidades, nos paradoxos, nos ecos, nas ambivalências. Faça de sua pesquisa uma busca de oximoros. Respire. Mais uma vez, respire.

- Ideias inspiradas na leitura da introdução de Ethnography and the Historical Imagination, de Jean e John Comaroff, livro publicado pela primeira vez em 1992. 
Introdução ....................................................................................10

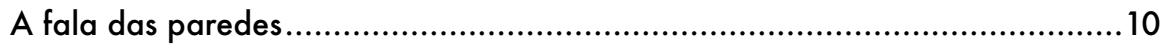

CAPÍTULO 1 ...............................................................27

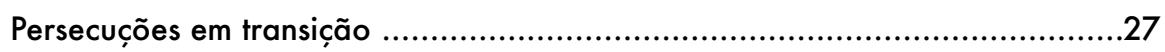

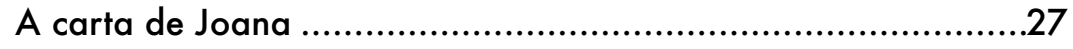

Verdade histórica, horror e fantasia ......................................31

Contra-insurgência democrática ..............................................39

Um informe de inteligência ...................................................45

Expurgar a violência, odiar a dialética ...................................49

A neutralização dos não-reconciliados ...................................59

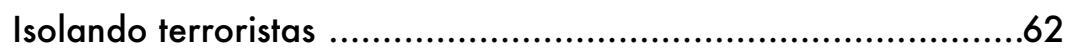

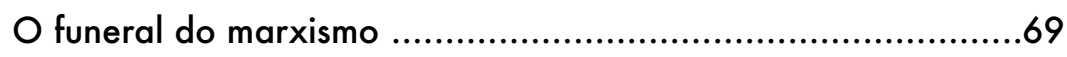

CAPÍTULO 2 ....................................................................75

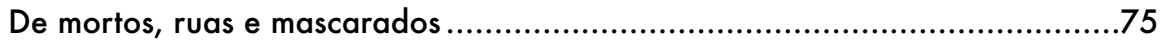

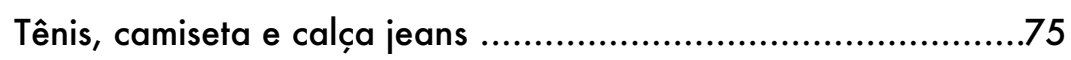

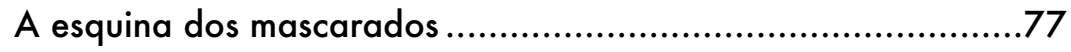

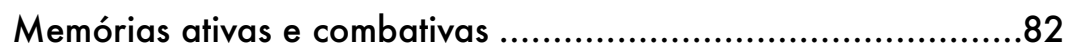

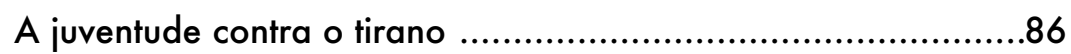

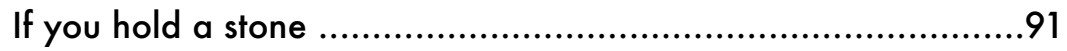

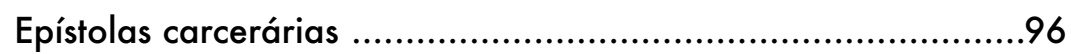

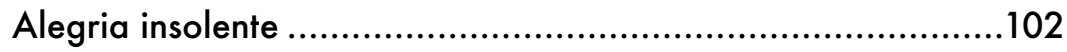

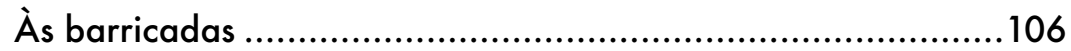

Observadores mascarados .....................................................111

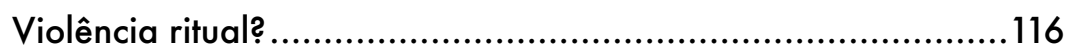

Ação direta, desfiguração e iconoclasmo ...............................121

Intermezzo ........................................................................... 132

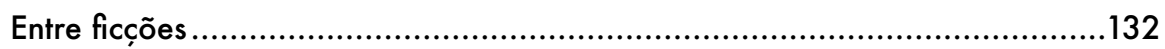

Mateluna: linhagens imaginadas ......................................132

Lobos e Ovelhas: anarcos na tevê ......................................140

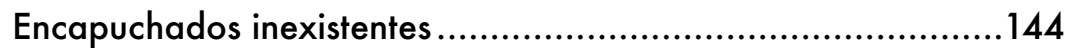

CAPÍTULO 3.............................................................................147

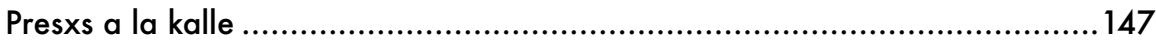

A aranha e o mandala ...................................................147

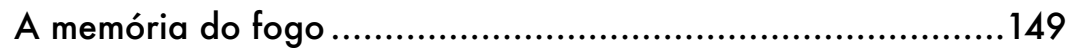

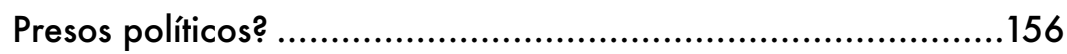

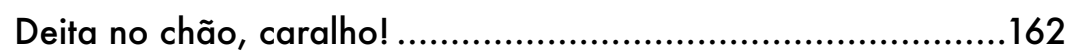

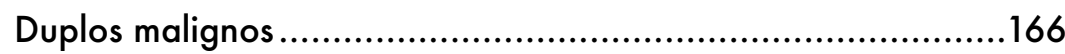




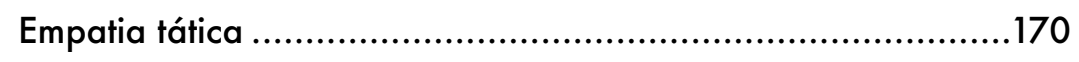

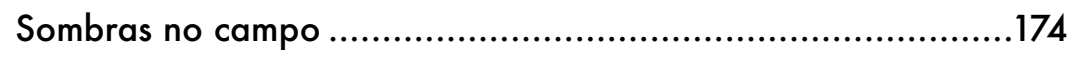

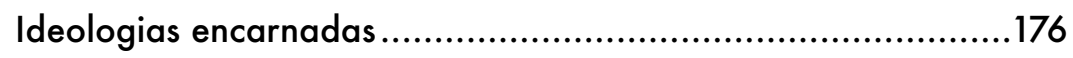

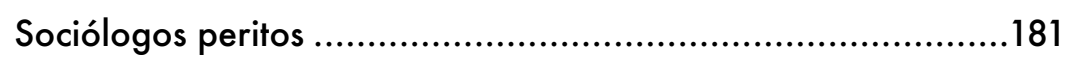

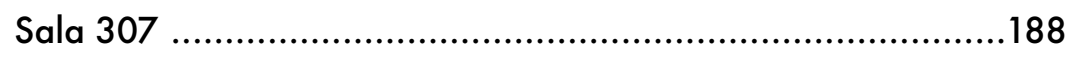

De mitocôndrias e mascarados...........................................195

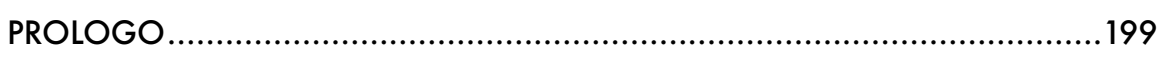

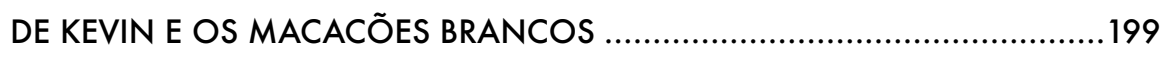

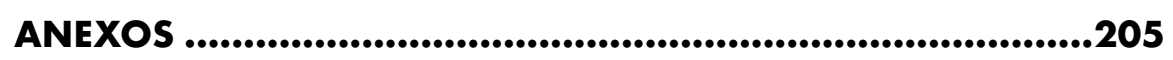

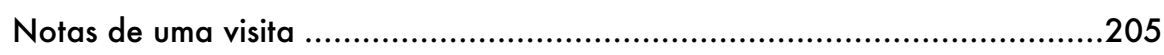

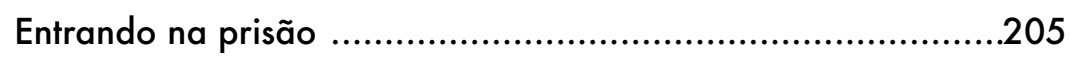

Acessos sempre incertos ...................................................206

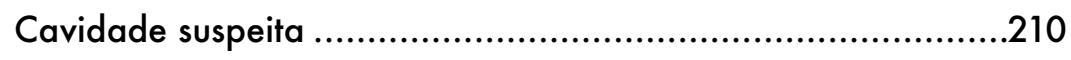

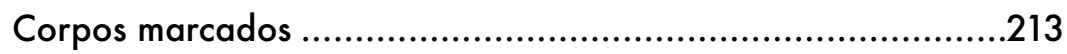

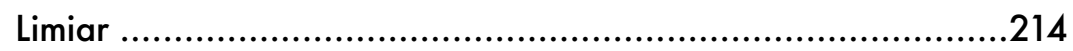

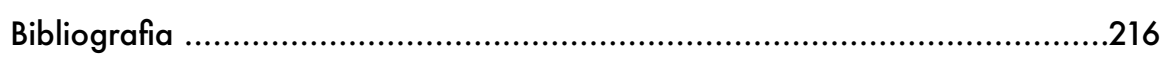




\section{Introdução}

\section{A fala das paredes}

Grego. Eu nunca consegui aprender a ler essa língua, mas isso não me impediu de ficar completamente pasmada quando, perambulando uma noite do verão de 2018 em um bairro próximo da Universidade Técnica de Atenas, por acaso, li algo no muro: Mauricio Morales $\Pi \alpha \rho$ óv!

Conhecido como o bairro anarquista, em Exarchia os envelhecidos prédios de baixa altura se alternam com livrarias, botecos, centros culturais e ocupações. Como se tratassem de estratos arqueológicos, aqui, os muros acumulam cartazes com convocações para passeatas, greves e shows de música punk. É possível, ainda, ver bandeiras pretas e vermelhas enfeitando as pequenas ruas próximas da praça principal do bairro, Plateia Exarchion, onde grupos de idosos e jovens, cada um em seu canto, aproveitam o sol da tarde, enquanto alguns turistas caminham vagarosamente lendo os muros grafitados ${ }^{1}$.

Nos limites exteriores do bairro, outras personagens são vistas: dia e noite, policiais conversam e fumam em um clima aparentemente descontraído à frente de um caminhão de choque que permanece como ponto fixo. Pela sua disposição para a revolta, há anos, Exarchia é assediada pela polícia, especificamente desde dezembro de 2008 , quando o bairro e a cidade foram palco de uma onda de protestos, depredações e saques deflagrados pelo assassinato de Alexandros Grigoropoulos². No lugar onde o

\footnotetext{
${ }_{1}$ Nos últimos anos, moradores de Exarchia têm se oposto ao processo de turistificação do bairro, com a chegada de ofertas gastronômicas anunciadas em inglês e o sistema de aluguel temporário via Airbnb. "A insurreição não é espetáculo: Exarchia não é um museu" - diz a consigna anti-turista.

2 No Brasil, a tese Política e anti-política: anarquia contemporânea, revolta e cultura libertária (2013), do cientista político Acácio Augusto, examina em profundidade o caso da revolta grega de 2008 .
} 
jovem anarquista de 15 anos foi morto pela polícia, hoje, há um improvisado memorial em preto e vermelho, com a sua fotografia e algumas flores.

A frase que li naquela noite, como soube dias depois, foi exatamente a mesma que tantas outras vezes vi em muros, no outro lado do hemisfério, há mais de 12 mil quilômetros de distância, em Santiago do Chile. П $\alpha \rho$ óv, em tradução literal para o espanhol, significa "presente", adjetivo que indica a presença de algo ou de alguém no presente. Desde as ditaduras civil-militares que marcaram com sangue e fogo a região latino-americana, "presente" é palavra que diz respeito àqueles que não estão mais conosco: os milhares de desaparecidos e executados políticos. Já com o retorno da democracia, em 1990, a expressão continuou a ser gritada em Santiago, não só em memória às vítimas do terrorismo de Estado, como também para invocar jovens anticapitalistas mortos pela polícia no Chile pós-ditatorial3.

Mauricio Morales, porém, pertence a uma linhagem um tanto distinta do que aqui estou chamando de ausentes presentes. O jovem chileno de 27 anos não faleceu nem pela violência policial nem pelo terrorismo do Estado. Seu corpo caiu decepado no asfalto em uma noite de 2009, em Santiago, quando a bomba caseira que carregava na mochila explodiu antes do tempo. Por acidente, o pretendido ataque a uma escola de formação de agentes penitenciários (ou, nas palavras de um blog ácrata, "factoría clonadora de carceleros"), transformou-se em imolação involuntária e ele, em mártir incidental4.

Sua imagem juvenil invadiu jornais e televisão, em reportagens que pretendiam explicar o que foi apontado como o motivo do ataque: o anarquismo. Sua figura e seu nome, ainda, continuam a serem disseminados em músicas punk, fanzines, panfletos, muros, dissertações acadêmicas e em documentários - fios e tramas de uma memória marginal e contracultural. Paralelamente, contudo, deu-se um processo análogo de memorialização, mas

3 Vale dizer que o termo ainda é usado para se recordar das vítimas da violência policial (e paramilitar), mesmo daqueles que, sem serem ativistas ou militantes, tiveram suas mortes transformadas em estopim para a mobilização de parentes, amigos e moradores de bairros na busca por justiça.

4 Imolação involuntária e mártir incidental são expressões cunhada por Adriana Cavarero (2009, p. 196) na sua análise do romance de Joseph Conrad, O agente secreto, onde narra a morte de Stevie, um suposto jovem anarquista que, como Mauricio, morreu ao explodir por acidente a bomba que carregava nas mãos. 
já no próprio coração do poder. A morte de Morales passou a ocupar lugar fundamental nas narrativas das unidades de inteligência policial e do Ministério Público chileno que, nos últimos 10 anos, têm buscado neutralizar o "anarquismo insurrecional".

Em 2018, um jovem foi condenado a 23 anos de prisão acusado de explodir uma bomba no metrô de Santiago. É a condenação mais longa por delito terrorista no Chile contemporâneo. Entre as evidências, laudos de especialistas confirmaram que o suspeito professava a "ideologia" do anarquismo niilista. A polícia chilena, em audiências, tem discorrido acerca da obra de Alfredo Bonanno, anarquista italiano que, em 2013, depois de participar de seminários no Uruguai e na Argentina, foi barrado pela polícia no aeroporto de Santiago e expulso do país. A imprensa reportou como a deportação do "ideólogo" mundial do anarquismo insurrecional5. As autoridades, justificaram a medida no sentido de que o homem, de mais de 70 anos, já havia sido condenado por roubos de bancos na Itália e na Grécia, décadas atrás.

O inquérito policial sobre o ataque anticarcerário frustrado, ocasião em que morreu Morales, estimou que o evento se inseria em uma série de ataques contra símbolos do Estado e do Capital ocorridos na capital chilena, entre 2005 e 2009 - explosões de baixa intensidade contra caixas eletrônicos, concessionárias de automóveis, delegacias policiais, igrejas, sedes de partidos políticos e, inclusive, dependências do organismo estatal de inteligência. De acordo com o Ministério Público, trataram-se de ações criminais acometidas por uma quadrilha terrorista que buscava "provocar a guerra social por meio do que eles [anarquistas insurrecionais] denominam a agudización dos conflitos e a ação direta e violenta contra o Estado, o capital, igreja, a burguesia e toda forma de autoridade" (Comité Investigador Caso Bombas, 2012, p. 14).

Os 14 imputados, vários deles jovens que moravam em uma okupa, passaram 8 meses em prisão provisória em uma unidade penitenciária de segurança máxima construída no início dos anos 1990 para encarcerar "terroristas de esquerda" que pretendiam desestabilizar o processo transicional chileno. Entre os suspeitos da quadrilha insurrecional, os

5 Para mais detalhes acerca desse episódio, ver: https://bit.ly/18GPb8d. Acessado em 04/05/2019. 
promotores públicos insistiam na existência de líderes: dois ex-presos políticos dos anos 1990. Depois de nove meses de julgamento, todos os imputados foram absolvidos e liberados. Porém, nos anos seguintes, outras estratégias seriam ativadas para aperfeiçoar a persecução criminal desse novo inimigo interno do século XXI: os ditos anarquistas insurrecionais.

Leandro foi o primeiro a me falar de Exarchia, em 2015. "Vamos embora para Atenas" - era a brincadeira com seus amigos que sonhavam não com praias, menos ainda com a Acrópole, mas com a revolta. Com vinte e poucos anos, o jovem já havia passado seis meses em prisão preventiva, suspeito de tentar queimar, junto com outros jovens, uma viatura policial. Era um 11 de setembro, data quando, ano a ano, são recordadas as milhares de vítimas assassinadas durante a ditadura militar que se iniciou com o golpe de estado contra o presidente eleito Salvador Allende, em 1973. Às passeatas e atos em diferentes pontos da cidade, durante a noite, somam-se barricadas e escaramuças entre os manifestantes e a polícia de choque, em bairros com um histórico de militância de esquerda.

O interesse desse jovem pela Grécia, ainda, tinha a ver com a Célula de Conspiração do Fogo. Definido como grupo, organização e/ou rede, a célula clandestina seria a responsável por uma série de ataques incendiários contra bancos e lojas de carros de luxo, bem como de cartas-bombas endereçadas a políticos gregos. Para os especialistas e acadêmicos engajados na segurança pública, tratar-se de uma nova geração de "terroristas" influenciada menos pelo marxismo e pela luta de classes, e mais pelo anarquismo insurrecional e a revolta.

"Eles, lá na Grécia, estão atentos ao que acontece aqui no Chile" - me comentou Rosa depois de sua absolvição, jovem que passou mais de dois anos em prisão preventiva acusada de ataque incendiário contra uma delegacia policial, evento que não deixou feridos. Rosa está certa: em blogs anarquistas, de fato, publicam-se cartas de presos gregos falando de presos chilenos, e vice-versa. São cartas escritas em um e outro lado do hemisfério, cumprimentando uns aos outros os outros companheiros capturados pelo Estado, compondo textos que saem da prisão para circular digitalmente na Internet. Trata-se de textos lidos com muita atenção, não só por aqueles que discutem o abolicionismo penal, mas inclusive pelas polícias especializadas 
em "terrorismo anarquista", categoria que hoje anda lado a lado com outras já mais conhecidas, como o "terrorismo jihadista", nos relatórios da Europol6.

Em inquéritos policiais no Chile, pela destruição de símbolos do Estado e do Capital (a polícia incorporou na sua linguagem tais definições), qualquer material salvo em computadores ou celulares acerca dos presos gregos, protestos nesse país ou textos sobre a dita célula são considerados evidência que confirma a ideologia dos suspeitos.

"Existimos em todo lugar, anarquistas que atuam ativamente; para nós, a anarquia não é um bate papo ideológico barato, mas uma forma de vida" explicava uma carta intitulada "Fogo de Solidariedade", assinada por presos gregos acusados de integrar a Célula de Conspiração do Fogo. A carta comentava a morte do jovem anarquista na falida explosão: "O Estado chileno deve saber que nenhum camarada será abandonado. É uma jornada insurrecional infinita orientada pelo novo niilismo e pela anarquia. Em algum momento, nos encontraremos, em Atenas, Santiago, aqui e agora, Mauricio Morales, presente".

Fogo e Asfalto explora como os mortos assombram o Chile pós-ditatorial. A tese se debruça sobre os intrincados caminhos pelos quais jovens rebeldes assassinados pela polícia ou mortos em "combate" passaram a conformar tramas de memória da esquerda radical, mas também, e de modo concomitante, de persecução criminal por parte do Estado. Para tanto, seguiremos os rastos de uma figura enigmática que, desde a década de 1980, vem assombrando as ruas de Santiago: o encapuchado. Essas figuras surgiram, especialmente, em efemérides que recordam manifestantes anticapitalistas executados durante a ditadura pinochetista e na pós-ditadura. Pelo anonimato e pela disposição em destruir objetos, lugares e corpos que encarnariam o Estado e o Capital, essas rebeldias são recusadas e expulsas para fora das margens da política.

Foi na década de 1980, entre pneus em chamas e barricadas, especialmente em protestos contra a ditadura pinochetista (1980-1990) em bairros periféricos, que jovens manifestantes saíram de rostos cobertos para evitar a identificação pelos aparelhos repressivos do governo de facto. Uma vez

6 Serviço Europeu de Polícia. 
iniciada a redemocratização, em 1990, contrariando o que se esperava, essa figura elusiva, um tanto fantasmagórica, outro tanto real, não deixou de irromper nas ruas da capital eventualmente: em protestos estudantis, em datas de recordação das vítimas da ditadura militar e em efemérides outras que, mais especificamente, buscavam lembrar de jovens manifestantes mortos pela polícia chilena, como é o Dia do Jovem Combatente, dia 29 de março.

Abjetos. Os mascarados são repudiados pela comunidade nacional de modo transversal: da esquerda à direita. Encapuchados? Nada mais seriam do que baderneiros sem proposições políticas claras. Para as lideranças do movimento estudantil, uma pedra no sapato que incitaria a criminalização dos protestos: afinal, por culpa desses grupos minoritários, aliás, as polícias são autorizadas a reprimir os manifestantes pacíficos. As cenas de barricadas de jovens com seus rostos cobertos lançando pedras e coquetéis Molotov na polícia tomam total a atenção da imprensa, às vezes deixando de lado as demandas dos movimentos sociais. Em vez de se falar de educação, a "violência nos protestos" passa a centralizar as discussões públicas. Por esses poucos - lamentam-se, ainda, os manifestantes que se "adequam às normas" -, todo o movimento é reprimido.

Desde o 2006, ano da afamada Revolução dos Pinguins, cada presidente chileno tem discursado publicamente contra os encapuchados. A democracia é questão de transparência: há de se participar com o rosto descoberto, repetem eles em uníssono. Projetos de leis já tentaram criminalizar o ocultamento do rosto em mobilizações de rua. E não só nesse país. Em Occupy Wall Street, em 2011 e 2012, manifestantes foram presos pela polícia por cobrir as suas faces. No Rio de Janeiro, a proibição das máscaras foi aprovada em 2013, pela irrupção dos chamados de black bloc. Em 2018, a França proibiu o uso de máscaras nos protestos dos "coletes amarelos”. Em Hong Kong, neste ano, em 2019, discutia-se como "leis anti-máscaras" podiam ajudar a frear a violência nas manifestações. Ocultar o rosto, portanto, é visto como um signo de suspeita, de propensão à baderna. Mas, ao mesmo tempo, do outro lado do espectro político, ocultar o rosto passou a ser "forma-de-ser" nos protestos, que, em diferentes lugares do mundo, tem sido uma estratégia cada vez mais corriqueira.

Ocultar o rosto é interpretado, ainda, como signo de covardia: se são tão rebeldes, por que não se mostram? Depois da morte de Morales, por 
exemplo, em um dos mais importantes canais do país, ao vivo, foram entrevistados dois integrantes do "coletivo anárquico" do qual o jovem morto era supostamente membro: "Por que não tentar dialogar e fazer as coisas com o rosto descoberto?" - rebatia o jornalista aos anônimos entrevistados, que apareciam de costas, com os rostos cobertos e as vozes distorcida baderneiros para a grande maioria. "E eles nem falam!" - exaltada, me respondia uma senhora com a qual comentava a minha pesquisa. Destruir caixas eletrônicos, erguer barricadas e se mascarar: que teria isso a ver isso com a política? - impugnam seus detratores. Como é possível fazer política com corpos que decidem não falar e se engajar na destruição material de símbolos? É assim, pela predisposição a destruir, que se lhes são negados qualquer conteúdo político, na medida em que não aceitam as formas da participação democrática e cívica. Violência vista como obtusa, surda e ardente, sem demandas nem discurso coerente. Eles seriam o exemplo perfeito do que Vera Telles tem chamado, com ironia, de "rebeldias malcomportadas" 7 .

Apesar da escassa simpatia que incitam na opinião pública e dos inúmeros esforços das polícias para neutralizá-los, os encapuchados continuam aparecendo: novas gerações novas adaptam essas formas e replicam os movimentos, mais uma vez na rua, para se enfrentar com a polícia. Resulta curioso, no entanto, como esse desgosto público, somado às inúmeras falas políticas acerca contra eles, traduzem-se em displicência acadêmica. Mesmo entre intelectuais à esquerda do leque político, prefere-se ignorar o assunto. Entre as centenas de publicações sobre os protestos estudantis em 2011 e nos anos seguintes no Chile, muitos simplesmente apagaram a presença dos mascarados de seus relatos de campo e de suas explicações analíticas. No geral, quando se trata de escolher movimentos sociais como objetos de estudo, há uma tendência de parte dos acadêmicos de atentar para as experiências coletivas que conseguiram impor suas demandas ou que conquistaram o a apoio de grandes parcelas da população.

Nesse contexto, essas dinâmicas mais violentas e que apresentam uma impressionante continuidade no Chile pós-ditatorial são reduzidas a uma nota de roda pé. Alguns argumentam: por que iriamos a falar desses radicais

\footnotetext{
$7 \mathrm{O}$ que seria da história se as rebeldias fossem sempre bem-comportadas? - é o que essa frase nos deixa pensando.
} 
se nada aportam para o movimento? E, se há tentativa de compreender mais detidamente essas formas de participação que implodem os marcos cívicos estabelecidos, por certo, ela vem acompanhada com o risco de ser acusado de fazer "apologia à violência”. A repulsa é tão transversal que me instiga a inverter a pergunta: como é possível que não queiramos adensar nos o nosso conhecimento acadêmico por entre os meandros desse fenômeno dos mascarados, por onde convergem anonimato, memória histórica e violência política?

Em retrospectiva, posso dizer que algo parecido aconteceu comigo quando, no mestrado, decidi pesquisar a onda de multitudinários saques no sul do Chile, após o terremoto de 2010 (Roca, 2016). Boa parte da população apontava com o dedo para os saqueadores como uma figura imoral: simples criminosos que se aproveitaram do desastre ocasional para roubar lojas e supermercados. Outros, mais à esquerda, os retratavam como sujeitos idiotizados pelo consumismo neoliberal. O que mais poderia explicar que um homem, no meio da devastação, resolvesse roubar e carregar nas costas uma televisão de plasma? Pois bem, as emoções que geram os encapuchados são um tanto quanto parecidas aos saqueadores: geram repulsa, desconcerto e raiva.

Nesse sentido, a minha intenção foi seguir na contramão dessa tendência acadêmica chilena ${ }^{8}$. Estar no Brasil ajudou a manter certo distanciamento com os modos com que o tema tem sido tratado e pensado em meu país de origem. De tal modo, terminei desistindo da noção de "repertório", cara à sociologia dos movimentos sociais. Depois de quase dois anos tentando encaixar os meus materiais nesses modelos analíticos, vi que não havia outra alternativa senão abandoná-los. A política da qual trato aqui na tese não é, tão e simplesmente, um movimento social. As teorias dos movimentos sociais têm sérias dificuldades para lidar analiticamente com a violência e, mais ainda, com o anonimato. A radicalidade das práticas e das narrativas dos encapuchados, como iremos ver, desafiam as gramáticas convencionais para analisar a vida política, pois tencionam os nossos marcos interpretativos; isso, a meu ver, nos proporciona um atalho estratégico.

\footnotetext{
8 Por certo, há trabalhos, e eu fiz questão de achar e trazer para a tese todas as publicações sobre o tema, apresentando seus argumentos e análises. É fundamental visibilizar essa produção acadêmica porque, curiosamente, ela também fica um tanto quanto oculta.
} 
Além dessas razões, há outro ponto, talvez mais fundamental, que justifica uma pesquisa como esta: como ignorar essas rebeldias minoritárias considerada a tamanha resposta estatal que eles suscitam?9 Afinal, esses "baderneiros" e mascarados têm mobilizado uma resposta estatal total: arranjos normativos, táticas de policiamento, tecnologias e saberes, regimes penitenciários dedicados ao problema da violência política - chamada pela polícia e pelo Ministério Público chileno de "violência antissistema", "anarquista", "insurrecional" ou, ainda, de "terrorismo". Ainda mais: é em razão desses grupos que o Estado se faz presente em todo o seu esplendor. Essas práticas de resistência, aos olhos do poder, são entendidas como afronta direta contra o próprio Estado (Bargu, 2014, p. 8). Pretendo de tal modo, indagar os excessos e as ansiedades do Estado na tentativa de combater aqueles que colocam como seu inimigo principal, justamente, o próprio Estado, atacando de forma aberta e espetacular os símbolos dominantes desse inimigo maior.

Esta tese é resultado de uma pesquisa etnográfica de mais de quatro anos, e se organiza em três capítulos. Em Perseguições em Transição, o primeiro capítulo, analiso a empreitada política e afetiva empreendida durante a redemocratização, projeto orientado pela ideia da reconciliação nacional que, por sua vez, colocou como principal inimigo da nação a figura do terrorista de esquerda, referindo-se àqueles que continuaram acreditando na violência como recurso na luta contra o capitalismo e contra a impunidade que protegeu os perpetradores do terrorismo de Estado nos anos da ditadura. Com base em documentos de agências de inteligência e instituições policiais, arquivos fotográficos, discursos presidenciais e notas de imprensa, discuto o processo de redemocratização, considerando os embates entre: i) a construção da verdade histórica sobre fatos acontecidos em matéria de violações dos direitos humanos no período ditatorial; ii) o policiamento dos não-reconciliados, ou

9 Esta questão aprendi com Banu Bargu (2014), teórica política e etnógrafa turca que se debruçou sobre as greves de fome de presos políticos na Turquia. Seu livro Starve and Immolate: The Politics of Human Weapons é uma peça preciosa que recomendo fortemente. $\mathrm{Na}$ edição do segundo semestre de 2019 da Revista Plural do Programa de Pós-Gradução em Sociologia da USP, há uma resenha minha do livro. 
seja, daqueles militantes de esquerda que impugnaram a legitimidade da redemocratização; e iii) a governança das emoções, a partir da qual, sob o imperativo do perdão, a reconciliação e do consenso, buscou-se expurgar o ódio, a vingança e a dialética marxista da alma nacional, ao mesmo tempo em que pretendeu-se inocular o amor à democracia no corpo político sob a égide do discurso dos direitos humanos.

Já em Mortos, Ruas e Mascarados, segundo capítulo, atento para as memórias de/por encapuchados. Nas últimas três décadas, jovens mascarados fusionaram-se provisoriamente em esquinas de Santiago para, a partir de movimentos específicos, recordarem jovens mortos pela polícia ao longo da ditadura pinochetista e nos seguintes regimes democráticos. Dentre os caminhos possíveis, a minha escolha foi entender tais rebeldias como movimentos de evocação e encarnação de experiências de engajamento político à margem das narrativas oficiais e partidárias. Se evocar é ato de tornar algo presente pelo exercício de memória e da imaginação, e encarnar é fazer-se carne, materializar-se em, incorporar um ente espiritual, a meu ver, estaríamos diante de exercícios cinéticos de recordação. Para dizer de outra forma, estaríamos diante de uma "memória ativa", como é chamada pelos jovens mascarados: uma memória que só se torna possível no concerto dos corpos anônimos, nos embates corpo a corpo com a polícia - o Estado-inimigo encarnado. No entanto, tais exercícios de recordação, de fazer viva a memória dos mascarados ausentes, se diferenciariam das lógicas, estéticas e práticas de memória promovidas pelas organizações de defesa dos direitos humanos e pelas políticas institucionais de memorialização ancoradas no conceito de "vítimas", visto como dispositivo que propiciou a desmobilização da população. Em contraposição, é erguida uma imagem dos "combatentes”: trata-se de recordar os mortos, mas de recordá-los em luta (e não em luto). Para avançar no argumento, mobilizo uma série eclética de materiais: jornais, músicas, fanzines, cartas, murais, entrevistas e relatórios policiais.

Inspirada em Georges Didi-Huberman (2017), proponho entender esses atos de recordação como gestos intensos, arranjos de materialidades humanas e não humanas, de temporalidades e afetos múltiplos que, em comunhão efêmera, no aqui e agora, recusam as regras de participação política cívica e obediente do estado de direito: "No gesto do levante, cada corpo protesta por meio de todos os seus membros, cada boca se abre e exclama o não da recusa e 
o sim do desejo" (Didi-Huberman, 2017, p. 118). São encontros impetuosos que abraçam a violência na sua dimensão destruidora e criativa; gestos intensos e sem fim, porque, a despeito das derrotas, persistem e voltam a ser postos em prática por novas gerações. São gestos sem fim, justamente por não buscar a tomada do poder.

Em Através dos desejos (Fragmentos sobre o que nos subleva), DidiHuberman questiona o esquema liberal que nega qualquer direito aos indivíduos de usarem a violência como recurso, menos ainda contra o próprio Estado. A destruição encenada pelas "rebeldias malcomportadas" é catalogada como perversão e desvio da luta entendida como correta nas democracias liberais, que se vangloriam da política do diálogo e da não violência como supostos princípios orientadores. É assim que a violência é posta à margem:

[...] quando, de fato, ela constitui o próprio cerne do problema de qualquer política, no leque completo da tirania até a emancipação. A violência estaria no coração do político: seria o turbilhão que enlouquece e precipita a história das sociedades humanas entregues ao confronto (Didi-Huberman, 2017, p. 362).

Questão difícil de se pensar, confessa o autor. Questão que nos petrifica. Mas, olhando para a história e não para os manuais de ciência política, é difícil negar que "não se recusa, não se desobedece, não se revolta, não se levanta sem violência, não importa em que grau" (Didi-Huberman, 2017, p. 367). É por isso que tantas e tantos morreram por se terem revoltado. De tal forma, caberia a nós pensar que os protestos poderiam ser vistos como revoltas de corpos e de objetos, alterações nas forças de gravidade, inércia e aceleração que passam a transtornar a ordem em vigor, a violenta ordem das coisas.

A paz liberal ergue-se no sangue e nos corpos silenciados à força. Se às vezes deixemos de ouvir o ronco surdo da batalha (frase célebre de Michel Foucault), não significa que as pugnas não foram sofridas, na pele, na carne, por aqueles que se insurgiram e que já não estão mais conosco. Isso vale tanto para regimes democráticos como tirânicos, porque, ainda que os primeiros se apresentem como não violentos e devotos dos direitos humanos, basta abrir o

\footnotetext{
1o Neologismo esplêndido cunhado por Vera Telles e que tem me inspirado no decorrer de toda esta tese.
} 
jornal para ver como, em nome da democracia e da liberdade, as engrenagens da violência continuam a se movimentar por entre nós. Mesmo que no Chile de hoje não se matem milhares, a violência policial segue sendo letal. Como cantava Victor Jara, músico e preso político executado com 40 balas pelo regime de Pinochet em 1973 ${ }^{11}$, no Estadio Chile, desconfie daqueles que "hablan de libertad y tienen las manos negras"12.

Seguindo a estrutura da tese, antes do Capítulo 3, há um intermezzo: texto breve no qual me debruço sobre as produções artísticas que têm em comum o fato de se inspirarem em eventos que, de uma forma ou de outra, envolvem os encapuchados. Esse material interessa-me para explorar as imbricações entre o factual e o ficcional que cada um desses registros problematiza. É por meio dessas considerações que antecipo questões que serão aprofundadas no terceiro e último capítulo, Presxs a la kalle, onde exploro a persecução criminal de jovens acusados de perpetrarem ataques contra os símbolos do Capital e do Estado. Para tanto, utilizei-me do material que coletei em trabalho de campo na prisão de São Miguel e no Centro de Justiça de Santiago, bem como de entrevistas que conduzi com jovens que foram acusados de acometer atos de violência antissistema e que, também eles, passaram meses em prisão provisória.

Documentos judiciais e policiais, bem como textos militantes, complementam o meu corpus empírico. Nesse capítulo, percorro três assuntos. Primeiramente, os modos pelos quais os jovens reelaboram suas experiências carcerárias nos meandros das "memórias combativas", nas tensões e ambiguidades no processo de auto identificação enquanto presos políticos do século XXI. Segundo, os regimes de segregação e de tratamento desses suspeitos, que fazem com que o discurso oficial, mesmo negando qualquer sentido político especial, na prática, mobilize dispositivos diferenciados aos dos presos por delitos comuns - fronteiras, por certo, flutuantes. Por último, as diversas tecnologias usadas na produção de evidências criminais contra os taxados como anarquistas, desde o confisco de livros e panfletos, as perseguições encobertas (o que chamo de polícia mimética), até tecnologias mais modernas de vigilância e controle social, como a identificação via DNA, a

${ }_{11}$ Em 2018, oito ex-militares foram condenados pela morte de Victor Jara. Mais informação disponível em: https://bit.ly/2jVXjUa. Acessado em: 02/05/2019.

12 A música "Vientos del Pueblo" foi lançada no disco póstumo Manifiesto (1974). 
geolocalização via telefone celular e o policiamento constante das redes sociais. Argumento que esse arranjo todo leva a uma produção de saberes acerca desse novo inimigo interno, sobre o qual se debruçam desde peritos de bioquímica até pesquisadores das ciências humanas, sempre com o objetivo de tornar seus inimigos internos visíveis e cognoscíveis, "desmascarando-os".

A tese, de certo modo, também é uma história familiar. Foi em junho de 2015, ano que voltei para São Paulo para iniciar o doutorado em sociologia, quando recebi um telefonema de Santiago que mudaria os rumos desta pesquisa doutoral. Ao ouvir a aflita voz de minha mãe, as distâncias entre a pesquisa e a vida familiar, de súbito, começaram a se apagar.

Adriana, filha do meu tio, ou seja, a minha prima de primeiro grau, havia sido presa polícia junto com outros quatro jovens acusados de incendiar, enquanto mascarados, uma delegacia policial, em novembro de 2014. Embora não tivesse havido feridos, nem grande destruição material de propriedades - apenas um carro queimado e paredes com rastros de cinzas -, sobretudo tendo em vista o alvo do ataque e a estética dos perpetradores, o episódio ganhou destaque durante semanas na imprensa chilena. Os especialistas em segurança rapidamente classificaram-no de crime terrorista cometido por uma célula muito organizada e audaz ${ }^{13}$. Representantes do Ministério do Interior disseram que utilizariam a Lei de Segurança Interior do Estado.

Uma vez terminada a ligação, acessei um dos principais sites de notícias do Chile e lá estava a sua foto com as mãos algemadas. A fotografia mostra Adriana sentada do lado do resto dos acusados. Sob a justificativa do perigo que a liberdade deles significava para a sociedade, o juiz decretou a

13 Depoimentos do senador Alberto Espina, especialista em segurança cidadã. Texto disponível em: https://bit.ly/2lUC7yz. Acessado em: 06/11/2015 
prisão provisória por três meses. Nesse ínterim, nenhum deles teria como saber que passariam os próximos dois anos em uma cela ${ }^{14}$.

Por razões de pesquisa, estava acompanhando o caso desde antes de se transformar em um assunto familiar. Era esse o tipo de empreitada contra lugares que eram símbolos do Capital e do Estado que eu pretendia explorar na tese. Quando preparava os primeiros rascunhos do projeto, em 2014, na última década, dezenas de jovens já haviam passado por prisão provisória na condição de suspeitos do crime de portar coquetéis Molotov em protestos, da queima de ônibus em datas de recordação de jovens militantes assassinados pela polícia, de explodir caixas eletrônicos com artefatos explosivos de baixo poder destrutivo, entre outros atos. No entanto, pensar no cárcere como possível local de pesquisa estava fora de qualquer cogitação. No Chile, como no Brasil, a solicitação de permissão para desenvolver pesquisas acadêmicas no sistema penitenciário é um processo demorado e que, no geral, é finalmente denegado. Essas dificuldades aumentam de modo exponencial quando se pretende entrevistar acusados ou condenados por crimes contra a segurança interna.

Contrariamente às nossas expectativas como família, quando voltei a Santiago no verão de 2016, Adriana continuava encarcerada. Passados os três primeiros meses da medida cautelar, o Ministério Público solicitou ampliar o prazo da investigação, argumentando a necessidade de realizar novas análises das evidências, solicitações que foram acolhidas pelos juízes cada vez que solicitadas, até chegar aos quase vinte e quatro meses de encarceramento preventivo. Os oito meses de investigação policial que antecederam a detenção dos jovens não pareciam suficientes. Os parentes se queixavam: se eles estão tão seguros de que os nossos filhos são culpados, então por que não dão início de uma vez por todas ao julgamento?

Foi assim que comecei a visitar Adriana na prisão de São Miguel. Naquele tempo, eu não pensava incluir a história dela na minha pesquisa. Como poderia chegar a escrever enquanto ela estava encarcerada e eu, livre?

\footnotetext{
14 Segundo cifras publicadas por Gendarmeria do Chile, em 2017, das 147.291 pessoas que se encontravam no regime fechado no Chile, 76.590 eram por medida cautelar de prisão preventiva. Ver: Gendarmeria do Chile, Compendio Estadístico Penitenciario, 2017. Acadêmicos têm alertado para o aumento persistente do uso dessa medida cautelar que, nos últimos 10 anos, chegou a se duplicar. Ver: https://bit.ly/2Eerop6. Acessado em: 97/11/2018.
} 
Junto a dúvidas éticas e metodológicas, me veio a possibilidade que, ao mencionar o vínculo de parentesco, me fosse mais fácil aceder a certos circuitos militantes. Sentia apreensão de que o difícil momento que ela vivia se transformasse em algo proveitoso e utilitarista para o meu trabalho. $O$ fato é que não aconteceu só uma vez colegas que, ao lhes confidenciar meus receios sobre a situação que vivia, me dissessem: "Olha só! Você vai ter uma ótima entrada no campo”. Boa sorte para a pesquisadora, má sorte para a família? Por essa razão, no primeiro período de campo, em 2016, resolvi não comentar dela a meus interlocutores, jovens também imputados por crimes semelhantes.

A isso, somavam-se receios acadêmicos: desconfiava que, ao incluir o caso de Adriana, a pesquisa pudesse ser alvo de críticas por carecer de "imparcialidade" e "objetividades" analíticas, dada a falta de distâncias entre o dito sujeito cognoscente e os sujeitos pesquisados (objetos cognoscíveis), passíveis de serem conhecidos. Não que acreditasse realmente na hipótese kantiana, ou em uma ciência social neutra, mas podia imaginar perfeitamente o olhar de recriminação de alguns sociólogos. Há décadas, Howard Becker (1967) e Gilberto Velho (1978) discutiram as distâncias e proximidades entre pesquisadores e interlocutores: ambos insistiram que, simplesmente, não existe o pretendido olhar imparcial. O antídoto para a paranoia sociológica de alcançar resultados científicos é lembrar que o pesquisador, mulher ou homem de carne e osso, sempre está observando desde um ponto específico. Como foi amplamente discutido pela teórica feminista Donna Haraway (1988), isso não significa uma celebração do relativismo, que, de certo modo, é o avesso daquele olhar conquistador e onipotente do eurocentrismo científico: ambos, no final das contas, dizem vir de lugar nenhum. Ao contrário, para a ela, trata-se de assumir as consequências de que toda a perspectiva é necessariamente localizável e parcial; logo, sempre estamos propondo saberes situados.

Com essas inquietações rondando as minhas reflexões, tive a oportunidade, em junho de 2016, de ouvir Gwenola Ricordeau e Karina Biondi15. As antropólogas discutiram os obstáculos vividos em suas respectivas pesquisas de campo, a primeira, na França, a segunda, no Brasil. Aliás, ambas são pesquisadoras do sistema prisional e, ao mesmo tempo,

15 Workshop “A prisão e seus afetos”, 10 junho de 2016, Instituto Polis, São Paulo. 
possuem parentes presos. Na ocasião, contaram como, em certos círculos acadêmicos, seus trabalhos foram criticados como "enviesados" por conta dos vínculos afetivos. Em mais de uma oportunidade, explicitar publicamente a entrada no campo transformou-se em armadilha: as discussões passavam a se centrar em tal questão, em vez de focar nas contribuições analíticas, metodológicas e teóricas propostas. Ouvindo-as, constatei que os receios que eu previa não eram tão infundados assim. Nesse sentido, decidi correr o risco.

Esta tese não é um manual de contra-insurgência. Tampouco, um guia para o desenho de políticas de segurança pública. No decorrer da pesquisa, ao comentar o meu trabalho, muitas vezes fui consultada no Chile acerca de como "resolver" o problema dos encapuchados. De forma nenhuma essa é a intenção deste trabalho. Tampouco, entregar pistas à polícia para melhorar a sua empreitada anti-insurrecional. Já no primeiro ano da tese, em 2015, quando apresentava achados em um congresso de antropologia em Montevidéu, me deparei com um policial brasileiro como público. Isso me colocou em alerta. No Chile, sabemos que as unidades de inteligência da polícia procuram pesquisas acadêmicas sobre tais assuntos. Há também os cientistas sociais que trabalham como analistas nas agências de inteligência civis e no Ministério Público. Além disso, sabemos que os parentes de presos políticos passam a ser incluídos em lista de suspeitos. Ou seja, há uma dupla possibilidade de, talvez, estas páginas incitarem o interesse policial.

Esta pesquisa não pretende ajudar na perseguição policial a esses grupos, mas sim contribuir na compreensão do funcionamento da contrainsurgência contemporânea. É por isto que meu trabalho não envereda para uma descrição de uma suposta "subcultura juvenil encapuzada", tampouco para a identificação de um "perfil sociológico" sobre os jovens que se engajariam em práticas de protestos disruptivos. Menos ainda busco elaborar uma definição do que realmente seria o anarquismo insurrecional e seus modus operandi. Paranoia da minha parte? Caberá ao leitor julgar.

Por certo, esta tese também não busca revelar o que há detrás do capuz, ou construir algo como a "verdadeira história" dos encapuchados chilenos. Na Internet, a quantidade de blogs e publicações escritas por anônimos mascarados é impressionante: eles não terão rostos, mas certamente têm voz - e muita! 
No decorrer destes anos, o impulso das minhas análises foi densificar: agregar mais capas, e não desvelar, correr o véu. Há uma frase em Indios Verdes, romance de um amigo escritor, Emilio Gordillo (2014, p.91), que de certa forma, sintetiza um pouco o espírito político deste trabalho: "Al desatarse, los nudos no dejan nada. Solo más nudos. Los nudos, los relatos, sirven para tejernos, no para andar resolviendo pinches enigmas". Nas miríades de histórias que iremos explorar, quero desamarrar nós, para depois voltar a amarrá-los. Acredito que são os mascarados a figura que nos permitirão entender melhor a história e o imaginário político do Chile póstransicional.

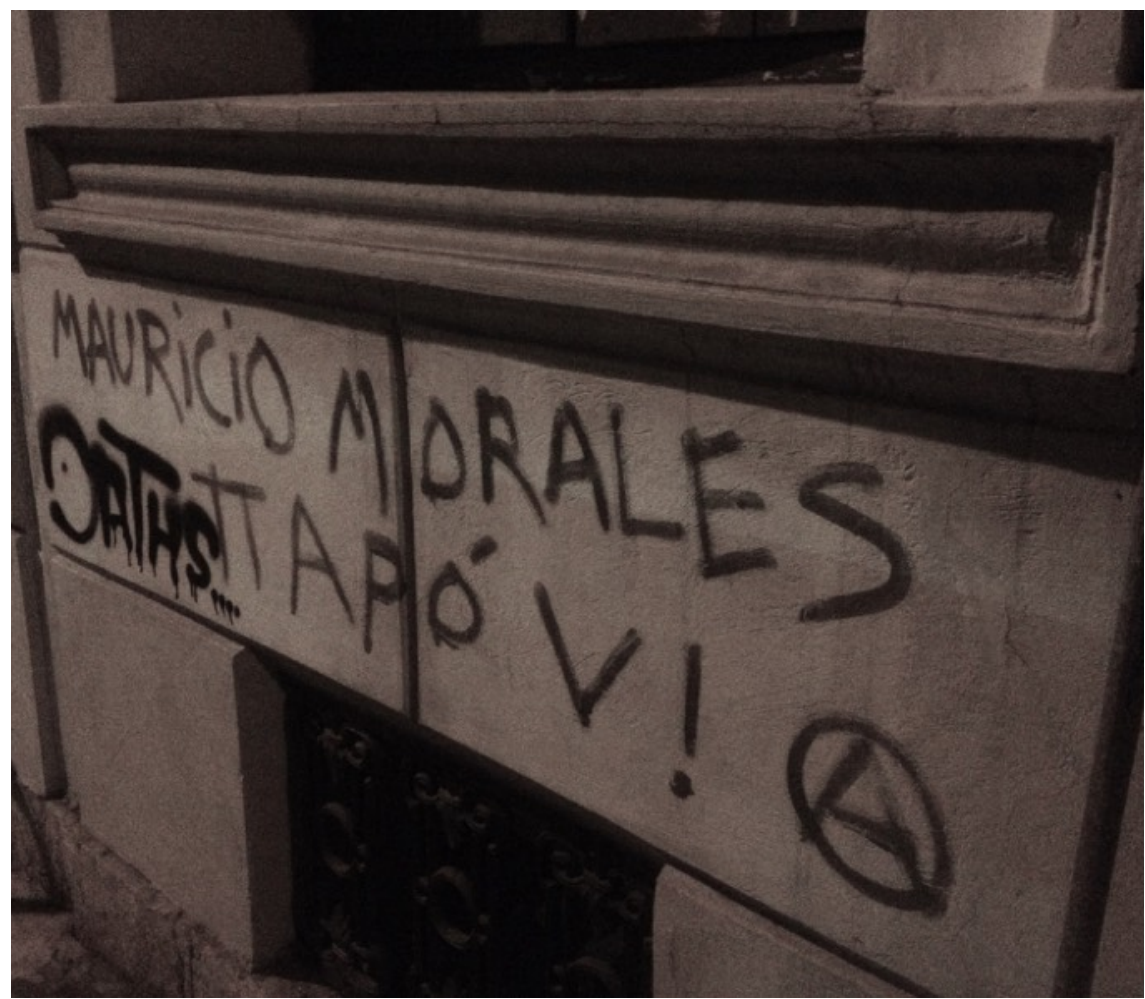

Figura 1:

Grafite em

bairro

Exarchia

(autora, 2018) 


\section{CAPÍtUlo 1 \\ Persecuções em transição}

\section{A carta de Joana}

Foi na véspera de natal de 1992 que Joana chegou às portas do Ministério do Interior, no centro histórico de Santiago, carregando uma carta nas mãos. Contudo, em vez de uma mensagem de fim de ano, a mulher com seus trinta e poucos anos denunciava, de punho e letra, as torturas e ameaças de morte recebidas em razão de suas convicções políticas. Naquela época, primeiros anos da redemocratização chilena, não eram inesperadas acusações de perseguição ideológica. Entre 1990 e 1991, a Comissão Nacional da Verdade e Reconciliação, convocada pelo presidente da república, o democrata cristão Patricio Aylwin, analisou mais de 3 mil testemunhos de prisão, tortura e morte conduzidos pela ditadura cívico-militar liderada pelo general Augusto Pinochet (1973-1990)16. Ao contrário da versão defendida pelo regime pinochetista, de que as denúncias de familiares e organismos de defesa dos direitos humanos não eram mais que uma campanha de difamação orquestrada pelo comunismo internacional, os especialistas que integravam a comissão chegaram ao "convencimento moral" de que, sim, houve violação sistemática, metódica e massiva dos direitos humanos no período analisado.

Um ano antes de Joana chegar às portas do ministério, em 4 de março de 1991, o ex-presidente Aylwin - que, vale lembrar, apoiou a derrocada

\footnotetext{
16 A Comissão da Verdade e Reconciliação foi criada pelo decreto supremo 355, em 5 de abril de 1990. Sua missão era: "Establecer un cuadro lo más completo posible sobre los graves hechos de violación a los derechos humanos, sus antecedentes y circunstancias; reunir información que permitiera individualizar a las víctimas y estableces su suerte y paradero; recomendar las medidas de reparación o reivindicación que estimara de justicia; y recomendar las medidas legales y administrativas que a su juicio debieran adoptarse para impedir o prevenir la comisión de nuevos atropellos graves a los derechos humanos" (Informe Rettig, vol. 1, 1991, p. 1).
} 
armada do governo do socialista Salvador Allende em 1973 -, em discurso televisionado, em nome do Estado do Chile, pedia perdão e anunciava reparações econômicas aos familiares das 2.115 pessoas reconhecidas pela comissão como vítimas da violência repressiva ${ }^{17}$. A política de extermínio levada a cabo até os últimos instantes do regime foi peça fundamental do projeto de reconstrução nacional liderado por Pinochet ${ }^{18}$. Tratou-se de um Estado autoimunitário (Montes, 2017), que foi capaz de implementar todas as formas imagináveis de violência para expurgar qualquer elemento marxista, tanto da economia quanto do corpo social chileno.

O Informe Rettig, como ficou conhecido o relatório de mais de três mil páginas elaborado pela Comissão da Verdade e Reconciliação' ${ }^{19}$, reconhecia, ainda, uma outra classe de vítimas: 164 homens e mulheres, na sua maior parte uniformados mortos em ataques ou durante enfrentamentos com militantes de organizações políticas consideradas de esquerda. Ambas as violências, o chamado "terrorismo de Estado" e os embates das vanguardas de esquerda contra o governo militar ilegítimo, indistintamente, passaram a ser definidas pela maquinaria tecnocrata transicional como "violações dos direitos humanos". Foi como vítima desse segundo tipo, vale dizer, como vítima da extrema-esquerda, que Joana se autoapresentava na carta entregue ao Ministério do Interior; mais especificamente, como vítima da Frente Patriótica Manuel Rodríguez (FPMR), grupo vinculado ao Partido Comunista chileno que, desde a sua fundação, em 1983, tentou derrocar o regime

17 Acerca da contabilização das vítimas da ditadura, é preciso dizer que a quantidade foi variando ao longo do tempo, à medida que novas comissões foram sendo organizadas, incluindo na rubrica vítimas os presos e torturados políticos do período. Em relação à gestão das políticas de reparação, ainda que a contabilização dos mortos, presos e torturados tenha sido fundamental para dimensionar a escala do horror, a crítica cultural Diamela Eltit diz o seguinte: "medir com números a violência, como principal metodologia, produz também violência na medida em que existe aí um processo de dessubjetivação tão definitivo que aniquila de novo as vidas concretas, até torná-las invisíveis, sintetizando-as numa aglomeração puramente aritmética" (Eltit, 2017, s/p).

18 Quando falo que a repressão continuou até os últimos dias do regime, não se trata de uma metáfora ou de um exagero retórico: em 4 de setembro de 1989, a poucos meses da eleição presidencial de 14 de dezembro, Jécar Neghme, dirigente do Movimento de Esquerda Revolucionária (MIR) morreu em um ataque seletivo de agentes da polícia secreta.

19 O documento se chama Informe Rettig em homenagem a Raul Rettig, advogado e militante do Partido Radical, que foi quem encabeçou o comitê. 
pinochetista de todos os modos possíveis, incluindo o frustrado atentando contra o ditador, em 7 de setembro de $1986^{20}$.

A carta de Joana diz assim:

Mi problema es netamente político. Siempre he sido de la ultra-derecha y tengo graves problemas con el Frente Manuel Rodríguez.

$1^{\circ}$ - Se me persigue por mi apellido de ser nazi, este viene de la 2 da guerra mundial de HITLER, de 1 médico alemán. Esto sale en la genealogia mormona.

$2^{\mathrm{o}}$ - Se me persigue por mi tío, coronel de la policía de Carabineros. Fue diplomático en Costa Rica en el gobierno del Excelentísimo Don Augusto Pinochet Ugarte. País donde mi tío tuvo problemas serios con la MAFIA y salió huyendo. Actualmente tengo problemas serios y agravantes por el Frente Manuel Rodríguez y un jefe de la mafia centroamericana.

$3^{0}$ - Se me persigue por haber tenido 1 novio militar y agente de la CNI [polícia política do regime militar] que fue asesinado el 4 de enero de 1986 por el Frente Manuel Rodríguez o ultra izquierda. La situación es caótica, las llamadas telefónicas y telegramas de TERROR han sido espantosos nunca pude denunciar a la policía el crimen o colocar 1 abogado, quedó todo acallado por ellos.

En el año 1979 fui violada y torturada y secuestrada por el jefe de Frente Manuel Rodríguez. Fui quemada con ácido, cigarrillos, se me puso corriente y hubo cuasi-homicidio. Fueron 19 terroristas: 16 hombres y tres mujeres. El jefe del Frente Patriótico Rodríguez manda toda la prostitución que hay en Chile. A él se deben muchos asesinatos tales como: Patricia Pinochet, Alice Meyer, Mónica Brione, crimen del general Fontaine, Don Jaime Guzmán Errázuriz, Crimen de Orlando Letelier, Crimen de mi comandante Leonardo Rebolledo de la Marina.

Tengo mi cuerpo lleno de nódulos. Se me ha puesto la CORRIENTE EN GENITALES Y EN EL CEREBRO. A raíz de tantos golpes y corriente y irradiación, estoy presentando serios diagnósticos como LEUCEMIA, PERFORACIÓN UTERINA Y OVÁRICA, TINITUS. Estoy totalmente intersectada por el Frente Patriótico Manuel Rodríguez. Esta gente opera con sistema de espionaje de EEUU, sistema espacial con circuito cerrado, cámaras, ultrasonidos, rayos $\mathrm{X}$, computadoras y grabadoras, líneas

20 Muitas vezes, a FPMR foi definida como o "braço armado" do Partido Comunista Chileno, tanto por autores próximos como contrários ao regime militar. Prefiro não repetir tal formulação, porque ela suporia certa subordinação do primeiro em relação ao segundo. Nesse sentido, a descrição "organização político-militar" do historiador Igor Goicovic (2010) pareceme mais apropriada analiticamente. Sobre o espetacular atentado contra Pinochet, ver: Verdugo e Hertz (2015) e Peña (2016). 
magnéticas, radar espacial donde lavan los cerebros y hacen que uno haga lo que ellos quieren y por lo general con DROGAS.

Son 1 cadena, son muchos. En cada comuna de Santiago hay jefes que utilizan estas máquinas. Se ha practicado la ALEVOSIAPREMEDITACIÓN-ENSAÑAMIENTO-SADISMO-TORTURA conmigo y lo mas grave de todo es que estoy sentenciada a muerte para antes de Navidad o Año Nuevo. "NN en la fosa común". Se dieron 2 órdenes de investigar a la policía, total que no han hecho nada por el momento por TERROR de las órdenes del Frente Patriótico Manuel Rodríguez ${ }^{21}$.

É com esta carta de Joana, que constitui um documento singelo perdido nas engrenagens burocráticas do Estado, que gostaria de dar prosseguimento ao primeiro capítulo desta tese, "Perseguições em Transição". Meu propósito é demostrar os meandros por intermédio dos quais, no alvorecer da redemocratização, emergiu, na arena pública e, mais especificamente, no campo da segurança pública, o "terrorista de extrema-esquerda" enquanto uma figura que não só ameaçava a paz social como também o próprio sucesso do processo transicional. Embasada em documentos desclassificados da primeira agência de inteligência civil pós-ditatorial, em discursos presidenciais, documentos da Comissão da Verdade e Reconciliação, notas de imprensa e fotografias, gostaria de discutir as readequações na doxa securitária na passagem do regime militar para a democracia. Em vez de uma ruptura radical, identifico contaminações, repetições e readequações entre os modos de conceber o inimigo interno em ambos os períodos e as políticas desenhadas para seu combate, indistinções possibilitadas pelo reajuste do discurso anticomunista no primeiro governo democrático, do ex-presidente Patricio Aylwin (1990-1994).

À diferença dos estudos mainstream acerca da redemocratização, eu entendo o processo de transição como projeto de pacificação da sociedade chilena, algo que pode ser subdividido em três dimensões: a) a construção da

\footnotetext{
${ }^{21}$ Carta original editada. Para facilitar a leitura, modifiquei a ordem dos parágrafos. Também, apaguei nomes e endereços de supostos militantes. As palavras em maiúsculo são do original. Vale dizer que na carta se fala de FMR, eliminando o "P" de "Patriótico" da sigla FPMR. Esse era o estilo usado pela imprensa que defendia o regime militar. Carta recuperada do arquivo digital Archivos Públicos da Universidad Alberto Hurtado. Por questão de preservar os nomes, não indico a sua localização exata.
} 
verdade histórica sobre os fatos acontecidos em matéria de violações dos direitos humanos no período ditatorial; b) o policiamento dos nãoreconciliados, ou seja, daqueles militantes de esquerda que impugnaram a legitimidade do processo transicional e que defenderam a necessidade de seguir utilizando a violência armada para lutar contra a impunidade que protegeu os perpetradores do terrorismo de Estado na recente democracia; e c) a governança das emoções a partir da qual, sob o imperativo do perdão, da reconciliação e do consenso, buscou-se expurgar o ódio, a vingança e a dialética marxista da alma nacional, ao mesmo tempo em que pretendeu-se inocular o amor à democracia no corpo político sob a égide do discurso dos direitos humanos. É assim que, no decorrer das próximas páginas, trago ao leitor uma miríade de procedimentos, instituições e agentes, bem como de discursos e simbolismos em relação ao "terrorismo" nos primeiros anos da pós-ditadura chilena, liderada pela coalização de centro-esquerda, denominada Concertación de Partidos por la Democracia ${ }^{22}$.

\section{Verdade histórica, horror e fantasia}

Para quem é próximo da história chilena, ler a carta de Joana é como cair de imprevisto em um pesadelo. No relato, superpõem-se perseguições, drogas e violência. Conspirativa, as tecnologias de espionagem e a lavagem cerebral aparecem juntas em uma narrativa perturbada e perturbadora pela indistinção, ou melhor, pela imbricação urdida entre fatos históricos e fantasias perversas. Técnicas de tortura próprias da repressão ditatorial no Chile e no resto do Cone Sul, como a aplicação de descargas elétricas nas

\footnotetext{
22 Essa coalizão partidária de centro-esquerda nasceu no contexto das eleições presidenciais de 1989 e articulou o Partido Socialista Chileno (PS), o Partido Radical (PR), a Democracia Cristã (DC) e o Partido pela Democracia (PPD). Extremamente bem sucedida em termos eleitorais, governou durante duas décadas: Patricio Aylwin (1990-1994), Eduardo Frei (1994-2000), Ricardo Lagos (2000-2006), Michelle Bachelet (2006-2010). Logo depois da derrota eleitoral nas presidenciais de 2010, quando venceu o candidato de Renovação Nacional (RN), Sebastián Piñera (2010-2014), a coalização reestruturou-se e passou a se chamar Nueva Mayoría, incluindo pela primeira vez o Partido Comunista Chileno (PC), articulação que logrou colocar mais uma vez Michelle Bachelet como presidenta (2014-2018) - mas que saiu derrotada nas eleições de 2017, quando Sebastián Piñera (2018-2021) regressou ao poder.
} 
genitais, na carta, são apresentadas em sentido invertido: como violências exercidas por terroristas da extrema-esquerda contra uma mulher defensora do regime ditatorial. O mesmo deslocamento, ou a mesma imagem em negativo, dá-se a respeito da ameaça de morte. A vala comum foi o destino não dos partidários da direita, mas sim de milhares de presos políticos de esquerda - ou de suspeitos de o serem -, como recorda o Pátio 29, fossa (hoje, lugar de memória) no Cemitério Geral de Santiago, onde corpos subversivos e corpos indigentes coabitaram durante décadas antes de serem identificados por peritos forenses.

A carta de Joana foi redigida em um momento em que os boatos acerca dos horrores do passado recente eram, pela primeira vez, reconhecidos como "fatos inegáveis" da história nacional. Apesar dos gestos do Estado para assinalar caminhos para a reconciliação do país, nessa conjuntura, os militares simplesmente se negaram ao processo de busca pela verdade e não ofereceram informações sobre os desaparecidos ${ }^{23}$. Porém, os mortos achariam seus caminhos de voltar à luz. Em 2 junho de 1990, em um dos momentos mais marcantes da história da redemocratização chilena, 19 executados políticos foram desenterrados por arqueólogos e ativistas no norte do país, nas redondezas de Pisagua 24 .

Um do lado do outro, de mãos e pés atados, com os olhos vendados, roupas e pertences preservados pela ação do deserto, os corpos mumificados confirmavam as práticas dos quase 1000 centros de detenção que

\footnotetext{
23 Só em 2003 o ex general Juan Emilio Cheyre, a máxima autoridade castrense no governo do socialista Ricardo Lagos (2000-2006), admitiria publicamente a responsabilidade do Exército na violação dos direitos humanos. Paradoxalmente, em 2018, Cheyre foi condenado por encobrir a execução de 15 presos políticos que ocorrera em 1973, na operação "Caravana de la Muerte", na cidade de La Serena.

24 A localização da vala comum de Pisagua foi possível graças ao trabalho do arqueólogo Olaf Olmos e o testemunho de Alberto Neuman, médico prisioneiro que foi forçado pelos militares a atestar a morte dos presos Tomás Cabello, Nicolás Chanez, Juan Mamani, Luis Manríquez, Hugo Martínez, Juan Rojas, Manuel Sanhueza, Julio Cabezas, Juan Calderón, José Córdova, Marcelo Guzmán, Humbero Lizardi, Luis Lizardi, Nelsón Márques, Mario Morris, Germán Palominos, Luis Toro, Juan Valencia e Alberto Yáñez. Em média, os prisioneiros assassinados tinham 34 anos no momento em que foram executados.
} 
funcionaram em todo o país25. A imagem dos aparecidos de Pisagua circularam profusamente na televisão e imprensa chilenas. Seus rostos desfigurados, suas mãos contraídas, seus cabelos intactos, tudo estava aí jazendo diante da nação²6.

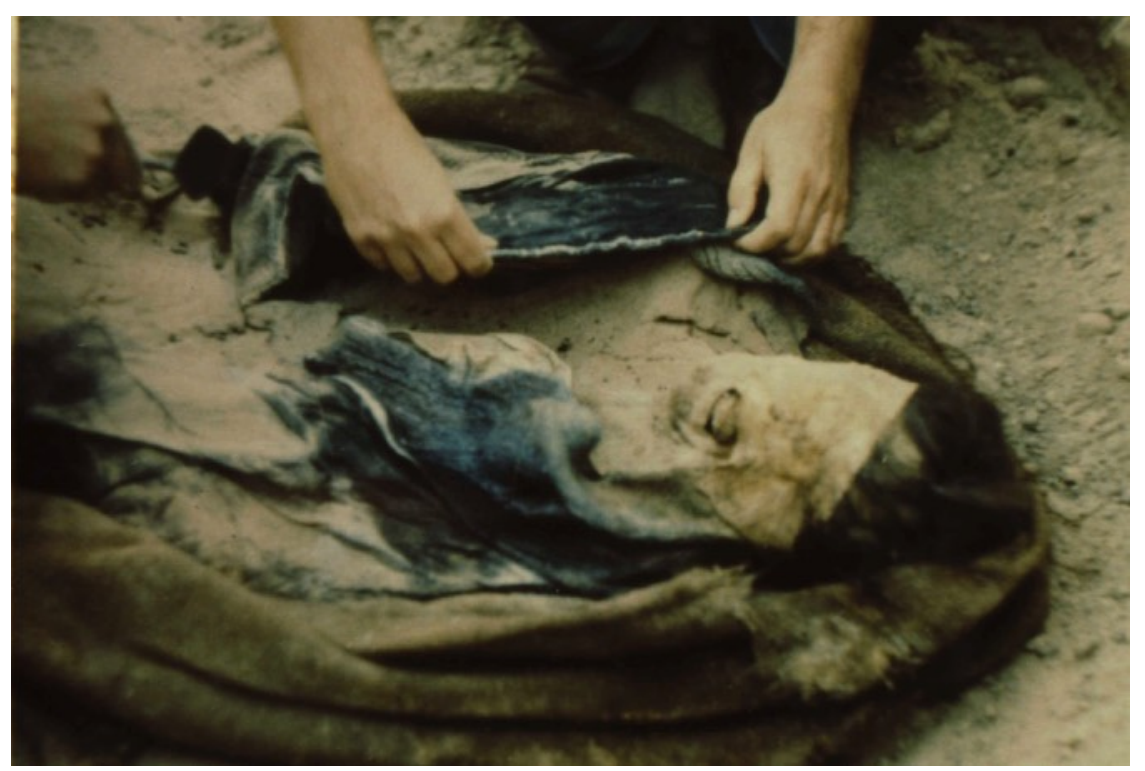

Figura 2:

Aparecido em Pisagua, (Vicaria de la Solidaridad, 1990)

O general Pinochet, homem branco, cabelos grisalhos e olhos azuis (como tanto gostavam de ressaltar suas apoiadoras), quando consultado por jornalistas pelas descobertas de Pisagua, respondeu com displicência olhando para as câmeras da televisão: "No tengo idea, fíjese". Ignorância agressiva sustentada pela soberba de quem não foi derrotado efetivamente, ainda que tenha perdido o Plebiscito Nacional de 5 de outubro de 1988: em nome da

25 Os 1.168 centros de detenção dos quais se tem conhecimento, hoje, operavam por meio da ocupação e reconversão de instalações previamente existentes: recintos militares, campos de concentração no deserto, estádios de futebol, passando por moradias residenciais no coração de bairros de classes médias e altas. O tempo de operação também era muito variável. Hoje, alguns deles têm sido recuperados por intermédio da luta das organizações de parentes das vítimas, como "lugares de memória” (Santos, 2016).

26 Vale dizer que, antes do caso de Pisagua, foi a descoberta de restos mortais na zona de Lonquén, em 30 de novembro de 1978, que fez com que, pela primeira vez, circulassem os rostos dos desaparecidos - claro que em publicações de esquerda, não na mídia hegemônica, como viria a acontecer em 1990. 
governabilidade e do consenso nacional, o ex-ditador teve um lugar reservado no coração da renascida democracia. Entre 1990 e 1998, atuou como comandante em chefe das Forças Armadas, e depois como senador vitalício, até $2002^{27}$. Além disso, nunca foi condenado no Chile por seus crimes, até a sua morte, em 2006, quando teve um funeral sem luto nacional, mas com honras militares.

As ameaças imaginadas por Joana, como a de ser assassinada e lançada em uma vala comum, inscrevem-se nos eventos da época. As passagens escritas acerca das violências exercidas por esquerdistas sobre o seu corpo tinham como intertexto evidente as técnicas de tortura constatadas pela Comissão da Verdade e da Reconciliação. Havia uma inversão lógica da ordem das coisas. Por exemplo, a violência sexual foi uma prática corriqueira dos agentes policiais e civis que trabalhavam nos aparelhos repressivos do Estado. Entre as técnicas utilizadas, o Informe Rettig enumerou o semiafogamento em água, excrementos e substâncias podres, o uso de correntes elétricas e queimaduras nos corpos, o "pau de arara", etc ${ }^{28}$. Ainda que o documento tenha usado linguagem imparcial, o horror transparecia nas descrições técnicas:

La forma más habitual de tortura era la "parrilla", que consiste en un catre de metal sobre el que se amarra desnudo al detenido para

\footnotetext{
27 O plebiscito de 5 de outubro de 1988 era para escolher se Pinochet permanecia no poder por mais 11 anos, ou seja, até 1997. A opção "No" ganhou com 55.99\% dos votos. A partir de então, organizaram-se eleições presidenciais (14 de dezembro de 1989), onde concorreram Patricio Aylwin (Democracia Cristã), Francisco Errázuriz (empresário não militante de direita) e Hernán Büchi (engenheiro, do partido liberal, a União Democrata Independente), que havia ocupado vários cargos na administração de Pinochet na área da economia. Aylwin ganhou com 55,77\% dos votos. A constituição de 1980 estabeleceu que os ex-presidentes que tivessem ocupado cargo por um período maior de 6 anos poderiam atuar como senadores "vitalícios" - condição que só Pinochet cumpria. Em 2002, o ex-ditador, que tinha regressado de Londres, onde permaneceu por mais de 500 dias impedido de sair por ordem do juiz espanhol Baltazar Garzón, que investigava a morte de espanhóis na ditadura, renunciou ao parlamento.

28 Única expressão em português no relatório da verdade, técnica de tortura exportada do Brasil ao mundo, cuja origem remonta ao tratamento dos corpos escravizados. As vítimas de torturas foram informadas oficialmente pela Comissão Nacional sobre Prisão Política e Tortura, no Informe Valech, publicado em 2004. Nesse primeiro informe, reconheceram-se mais de 27 mil vítimas, cifra que aumentaria para 40 mil em relatórios posteriores.
} 
proceder a aplicarle descargas de corriente eléctrica sobre distintas partes del cuerpo, especialmente aquellas más sensibles como los labios o los genitales, y aun sobre heridas o prótesis metálicas. Una modalidad particularmente cruel de este método consistía en la utilización de un camarote metálico de dos pisos; se colocaba al interrogado en el de abajo y en el de arriba se torturaba a un pariente o amigo suyo, como modo de presionarlo aun más (Informe Rettig, Vol. 1, 1991, p. 466).

A carta de Joana é uma fantasia horrível, ainda que sua lógica seja baseada em fatos reais. Ao ler "perfuração uterina e de ovários", eu, que nasci em 1982, me lembrei de algo que escutei de uma amiga da escola, em meados de 1994, ou seja, dois anos depois da denúncia de Joana: "Ratos, Andrea... os milicos torturavam as presas colocando ratos nas suas vaginas". Isso me faz lembrar que as ditaduras latino-americanas, entre tantas outras coisas, foram projetos de disciplinamento, extermínio e desaparição de corpos subversivos, uma "ortopedia monumental" sustentada por meio de uma engrenagem de produção sádica de conhecimento (Parrini, 2006, p. 36). Sádica, pois de que outro modo poderíamos entender o fato histórico que uma funcionáriatorturadora, policial de alta patente, primeiro, havia treinado um cachorro para estuprar mulheres e homens, e segundo, tivesse resolvido the dar de apelido o nome de um dos máximos dirigentes do PC Chileno?29 Ou, ainda, de que outro modo poderíamos entender a gana de militares de forçar pessoas a assistirem a tortura de entes queridos ou tentar obrigar homens e mulheres a manterem relações sexuais com seus parentes?30

Tratou-se de um sistema massivo de produção de verdade, desamparo e morte que afetou com maior força os presos oriundos de setores populares (Eltit, 2017). Aliás, nessa engrenagem sádica de policiamento e sevícias, teria

29 A policial era Ingrid Olderock, que deu o apelido de "Volodia" ao cachorro treinado para torturar "subversivos", em referência a Volodia Teitelboim, liderança comunista que fora senador por Santiago. Para mais informação sobre esse caso, ver: Guzmán, N. (2014).

30 Assim testemunhou a ex-militante do MIR, Nieves Ayress, para a Comissão Nacional sobre Prisão Política e Tortura em 2010. O relato de Nieves é um dos mais fortes registrados até hoje, testemunhando inclusive a inserção de ratos na vagina das mulheres e de garrafas de Coca Cola no ânus dos presos e presas, enquanto os sequestradores lhe gritavam: "Para que sientas el Imperio". Depoimento disponível em: https://bit.ly/2qKo4vI. Acessado em: 04/12/2018. 
trabalhado o suposto namorado de Joana, mais especificamente na Central Nacional de Informações (CNI), polícia política do regime de Pinochet, que teria sido assassinado pela FPMR.

O Informe da Comissão Nacional da Verdade e da Reconciliação e a carta da Joana são documentos marcados pela dor e pelo suplício. Ambos testemunham, acredito, os dilemas da redemocratização chilena. Na carta de Joana, é o "terrorista da extrema-esquerda" o responsável por todo o sofrimento, apresentado com capacidades admiráveis de vigilância, violência e extorsão, com a habilidade de se imiscuir nos espaços mais íntimos do adversário: útero, ovários, ouvidos e cérebro. Onipresente e onisciente, seja por ondas eletromagnéticas, lavagem cerebral ou então seguimentos secretos, o corpo imaginado de Joana está completamente submetido à crueldade de seus inimigos fantasmagóricos.

Essa sensação de estranhamento radical com o próprio corpo afetado por forças exteriores e superiores é sintoma comum entre pacientes com surtos paranoicos que, no geral, são acompanhados por relatos conspiratórios mediante os quais os pacientes estabelecem conexões disparatadas entre a sua biografia pessoal e a geopolítica mundial (Goidanich, 2003). É assim que a FPMR ${ }^{11}$, os mórmons, Hitler, a máfia caribenha e a espionagem estadunidense convergem em sua carta. Entre distorções e fatos, entre o certamente improvável e eventos de público conhecimento, os relatos conspiratórios chegam a circular e a serem (re)produzidos. Para que as histórias sejam audíveis, devem deixar leitores pensando, ao menos por um instante: e se fosse verdade?32

\footnotetext{
31 A FPMR surgiu do PC Chileno em 1983. A outra organização da qual falarei é o MIR, organização político militar que existia antes do Golpe de Estado, tendo nascido nos anos 1960 a partir de uma longa tradição de esquerda extraparlamentar e sob influência da Revolução Cubana. Apesar de suas diferenças, ambas partilhavam da luta revolucionária, como também das cores oficiais da sua parafernália política, bandeiras e pañoletas.

32 Embora a mentira, a falsificação e a manipulação estejam longe de ser elementos novos da política, recentemente, as teorias conspiratórias e as chamadas "fake news" têm ganhado importância como objeto sociológico, pelo menos desde o triunfo eleitoral de Donald Trump nos Estados Unidos e de Jair Bolsonaro no Brasil. Sobre o caso americano, ver: Polleta e Callahan (2019).
} 
Joana também faz menção a feminicídios bastante noticiados entre 1984 e 1985. Me refiro à morte de Mónica Briones, lésbica golpeada até a morte na rua; de Alice Meyer, jovem da elite encontrada morta em uma várzea na periferia de Santiago; e Patricia Pinochet, chilena esquartejada depois de um aborto frustrado na Argentina. Os sofrimentos dessas mulheres, corpos dilacerados pela violência patriarcal, na narrativa fantástica de Joanna, são reelaborados como crimes terroristas. O exercício contrário, quer dizer, de crimes terroristas apresentados como feminicídios, foi prática corriqueira entre os especialistas estatais em violência. Marta Ugarte, por exemplo, militante comunista e dirigente do Colégio de Professores, foi presa, torturada, assassinada e lançada por militares desde um helicóptero ao mar, em 9 de setembro de 1976. Em poucos dias, seu corpo apareceu na beira de praia La Ballena, no litoral central, descoberta que foi noticiada pela imprensa como mais um crime passional33. Entre as táticas utilizadas para ocultar o extermínio de dissidentes, as montagens post mortem não foram infrequentes. Cadáveres de militantes mortos a tiros pela polícia eram dispostos na cena do crime de tal forma que a ordem dos elementos, dos corpos e das armas corroborasse a versão-ficção policial, a saber, que as execuções eram atos de legítima defesa diante dos desenfreados terroristas de esquerda34.

Na carta de Joana, obviamente, há referência a crimes políticos que impactaram a opinião pública naqueles anos, como o carro-bomba planejado contra Orlando Letelier nos Estados Unidos, ex-ministro de Salvador Allende, em 1976. Contudo, ao contrário de sua crença, o ataque foi considerado a primeira atividade terrorista internacional da polícia secreta de Pinochet. Ataques de fato reivindicados pela FPMR citados por Joana foram os

\footnotetext{
$33 \mathrm{O}$ diretor chileno Patricio Guzmán reflete sobre a história de Marta no filme O botão de nácar (2015). A história também aparece na música popular "Vino del mar", do grupo Inti Illimani, lançada no disco Lugares Comunes (2002), com letra do escritor e músico Patricio Manns: "Vino del mar/Con una cicatriz/Que dividía su pecho en dos/Trazada por/un furioso puñal/que eternizó su indefensión”.

34 Com respeito às montagens post mortem da polícia, a justiça chilena reconheceu a utilização dessa tática de encobrimento no caso Operación Albania, operativo orquestrado pela polícia secreta e pela CNI, que ocasionou a morte de 12 militantes da FPMR em 15 de junho de 1987, execuções que foram, na verdade, represálias pela tentativa de assassinato de Pinochet, em setembro de 1986.
} 
assassinatos do coronel de inteligência policial, Luis Fontaine35, em 11 de maio de 1990, e do senador Jaime Guzmán, em 1 de abril de 1990, este último tendo sido assessor de Pinochet e advogado artífice da Constituição de 1980 - vigente até hoje, diga-se de passagem, e que sentou as bases do modelo jurídico e social legado pela ditadura 36 .

Qual seria o sentido de resgatar um relato atormentado, espécie de falsificação da dor alheia sofrida por milhares de militantes torturados e mortos na ditadura? Por que se importar com uma narrativa excessiva e obcecada com o suplício que, a momentos, resulta insuportável ao se lembrar que muitos das e dos desaparecidos chegaram a esse fim por culpa de denúncias e delações de pessoas comuns como Joana? Qual a relevância histórica de se pensar, desde as ciências sociais, em um registro que, por sua falta à verdade, possivelmente seria desestimada por especialistas em direitos humanos e justiça transicional, assim como por historiadores debruçados sobre a redemocratização chilena e sobre a violência política?

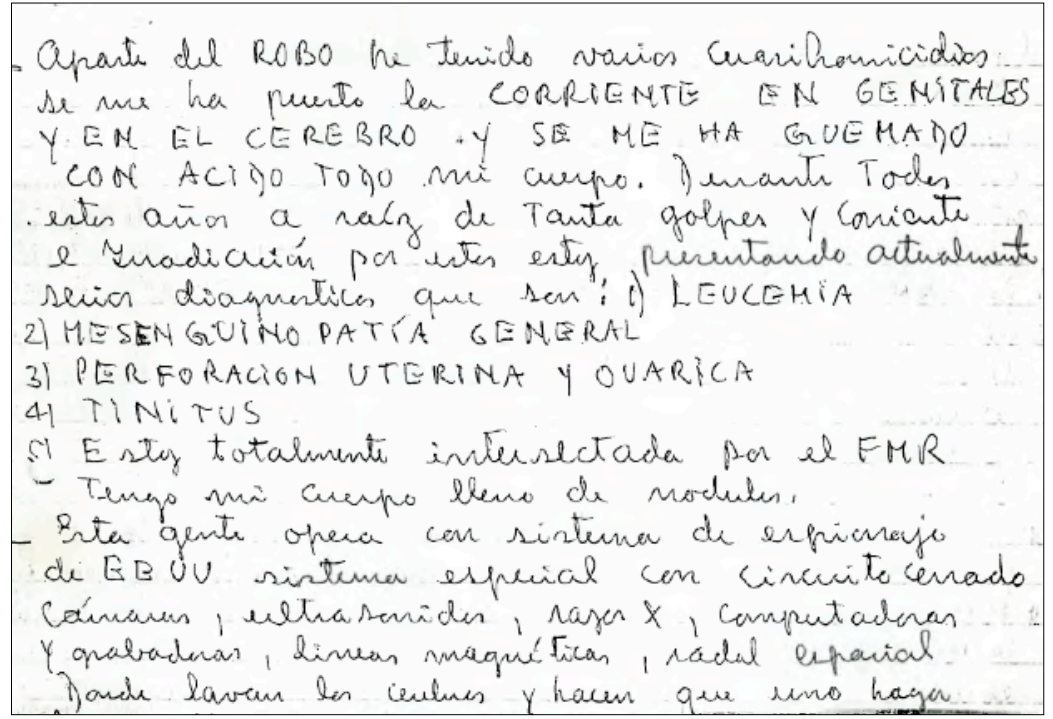

Figura 3: Excerto da Carta de Joana (Consejo de Seguridad Pública, 1993)

\footnotetext{
35 Luis Fontaine foi acusado de ser responsável pela morte de Carlos Godoy, jovem de 23 anos, executado em 22 de fevereiro de 1985 durante interrogatório da polícia. Carlos foi detido acusado de guerrilheiro treinado em Cuba, país onde viveu o exilo com sua mãe até o ano anterior a sua morte. Fontaine foi deixado em liberdade pela justiça militar.

36 As execuções acometidas durante o período democrático contra pessoas que participaram do terrorismo de Estado eram compreendidas por seus perpetradores como atos de justiça popular contra a impunidade que amparou torturadores no processo transicional, bem como uniformados, civis e integrantes da elite que se beneficiaram do regime pinochetista.
} 
Em um primeiro momento, eu mesma considerei inapropriada a carta como material empírico de pesquisa. O desconforto que me causou sua leitura foi tal que a salvei em uma pasta junto a outros tantos documentos peculiares achados ao longo do doutoramento. Em poucos dias, no entanto, reconsiderei seu potencial. A denúncia de Joana me parece agora tudo menos marginal. A carta que quase joguei no lixo por suas fantasias e distorções fantasmagóricas merecia ser lida desde outra perspectiva analítica pela simples razão de que fora registrada, carimbada, assinada e posta em circulação na engrenagem burocrática, até chegar às mãos do mesmíssimo Ministro do Interior. A carta, transformada em documento de Estado, arquivo reservado, aqui compõe um texto profícuo, não para compreender o sofrimento psíquico de uma mulher em particular, e sim para enxergar dinâmicas especulares e paranoicas que caracteriza o encontro entre a entidade Estado e a entidade Terrorismo (Aretxaga, 2000; 2003; Roca, 2019; Shoshan, 2016).

Aliás, esse documento preservado nos arquivos ministeriais e que, décadas depois, viria à luz em virtude do trabalho de digitalização do acervo do governo de Patricio Aylwin, mais do que falar de Joana, também diz algo acerca do Estado chileno e de suas ansiedades, desejos e paranoias políticas: os afetos do Estado, ou melhor, o Estado afetado. Em outras palavras, este relato disparatado, na avaliação dos especialistas em contrainsurgência, era um relato que poderia levar a alguma pista certa sobre grupos de esquerda que continuaram operando nos primeiros anos da redemocratização e que se transformaram em alvo do governo do ex-presidente Aylwin. Foi assim que os inquéritos e as persecuções se iniciaram.

\section{Contra-insurgência democrática}

No anseio por reconciliação nacional, os direitos humanos e a segurança pública passaram a ser as duas caras da mesma moeda, que 
conotavam apenas uma luta: a pacificação da nação37. Na arquitetura transicional chilena, junto à Comissão da Verdade e Reconciliação, ainda houve um outro corpo assessor do executivo preocupado em contabilizar vítimas. Por decreto supremo emitido pelo Ministério do Interior em 18 de abril de 1991, criou-se o Conselho Coordenador da Segurança Pública, a primeira instituição de inteligência pós-ditatorial38. Seu objetivo era o de assessorar o poder executivo no planejamento estratégico e na coleta de informações relacionadas à ação de grupos "subversivos" (ou, violentistas) que desconheceram a legitimidade do processo político de redemocratização e continuaram acreditando no potencial das armas na luta pela justiça e pelo fim do capitalismo.

O Conselho Coordenador da Segurança Pública, como usualmente acontece nesse campo, surgiu de uma dita crise securitária. Em 1 de abril de 1991, o senador Jaime Guzmán, advogado, assessor direto do general Pinochet e artífice da constituição de 1980, foi morto a tiros por militantes da FPMRAutónomo39. Aos olhos dos partidos de direita e da imprensa próxima ao regime militar, o ataque fora evidência da incapacidade do novo governo para assegurar a governabilidade no país. Em outubro de 1990, o Ministro do Interior, Enrique Krauss (que, em 1973, junto a outros militantes da Democracia Cristã, viajaram pela Europa defendendo a necessidade da

37 Um dos primeiros autores que analisou a pacificação como princípio analítico para entender a lógica da segurança pública nos primeiros anos da redemocratização foi Pedro Rosas (2013), ele próprio, ex-preso político na transição. Pedro se licenciou em sociologia quando privado de liberdade; hoje ele é professor universitário.

38 Decreto ${ }^{\circ}$ 363, publicado em Diario Oficial na edição de 18 de abril de 1991. O conselho operou até o dia 30 de abril de 1993, sendo sucedido, em 30 de abril de 1993, pela Dirección de Seguridad Pública e Información. No jargão popular, esse organismo foi batizado pela imprensa como "La Oficina", sendo que este é o nome usualmente utilizado. Nesta tese, entretanto, preferi usar o nome oficial.

39 Em 1987, a FPMR se dividiu em duas frentes: uma, que apostou na redemocratização, e outra que a recusou - a FPMR-Autónomo. Na opinião pública e na imprensa, todos eram tratados como "frentistas". Recentemente, alguns dos acusados de cometer o assassinato de Guzmán, que viveram durante décadas na clandestinidade nos mais diversos países, obtiveram refúgio político na França (Ricardo Palma Salamanca) e na Bélgica (Miguel Ángel Peña). 
tomada do poder por parte dos militares $4^{\circ}$ ) recebeu uma carta das lideranças do partido conservador Renovação Nacional (RN), que se queixavam do recrudescimento das atividades terroristas, que contabilizavam ataques explosivos, revoltas em prisões e a existência de transmissões clandestinas de rádio com conteúdos subversivos. Criticavam, ainda, a pouca decisão do governo em defender o Estado de direito e proteger a democracia, sobretudo ao indultar "terroristas" que já tinham sido condenados na ditadura ${ }^{41}$.

A morte de Guzmán, a poucos dias de divulgado o Informe Rettig, teve repercussão internacional. Mandatários estrangeiros enviaram condolências a Aylwin, entre eles o presidente espanhol, o socialista Felipe González, que junto com condenar "tão execrável acontecimento", reforçava o compromisso na luta internacional contra o terrorismo42. Outras autoridades, como o presidente do Banco Interamericano do Desenvolvimento (BID), em carta pessoal dirigida ao presidente, lamentou o ataque interpretado como "gestos dementes de minorias perdidas na história" 43 . Por sua vez, em uma entrevista para um jornal alemão, o próprio presidente Aylwin, ao mesmo tempo em que se preocupava com o impacto que esse tipo de ação pudesse ter na "confiança" dos mercados para investir no Chile, discorria sobre a falta de racionalidade dessas ações ditas revolucionárias. E isso, obviamente, ganhou outras proporções tendo em vista o contexto mundial da época, marcado pela

40 Uma sorte de "Truth Squad" - conforme relatório da CIA -, do qual participaram Pedro Jesús Rodríguez, Juan Hamilton e Juan de Dios Carmona. Disponível em: https://bit.ly/ 2x1It1O. Acessado em: 10 de junho de 2019.

${ }_{41}$ Carta da Renovación Nacional para o Ministro do Interior, Enrique Krauss, com data 26 de outubro de 1990. Documento $\mathrm{n}^{\circ}$ oo8755. Carta recuperada do arquivo digital "Archivos Públicos” da Universidade Alberto Hurtado. Disponível em: https://bit.ly/2ASvRMt. Acessado em: 03/11/2018.

42 Palavras de condolências de presidente espanhol Felipe González, em 4 de abril de 1991. Telegrama recuperado do arquivo digital "Archivos Públicos" da Universidade Alberto Hurtado. Disponível em: https://bit.ly/2ZzsTXu. Acessado em: 13 de novembro de 2018. Anos depois, reforçando essa ideia do "especular" na luta antiterrorista, o próprio González seria processado por delitos terroristas pela sua responsabilidade na organização dos Grupos Antiterroristas de Liberación (GAL), integrados por agentes estatais que se utilizaram da violência política, da infiltração e dos atentados para combater o ETA em território espanhol.

43 Carta de condolências encaminhada ao Presidente Patricio Aylwin em 5 de abril de 1991. Carta recuperada do arquivo digital "Archivos Públicos" da Universidade Alberto Hurtado. Disponível em: https://bit.ly/2KjOq1g. Acessado em: 12 de novembro de 2018. 
queda do muro de Berlim e, claro, pela atuação de grupos de esquerda armada na Alemanha, como a Rote Armee Fraktion, que continuou operando nos primeiros anos de 1990.

Independientemente de lo que pasa en el mundo, ellos siguen creyendo en el marxismo. Esto es un anacronismo. Este terrorismo es irracional. No encuentro una explicación lógica para esto. Si los terroristas pretenden transformar la sociedad chilena, van a lograr justamente lo contrario. La gran mayoría de los chilenos odia la violencia, rechaza este tipo de lucha política y defiende la democracia. Prefieren llegar al consenso antes que a la confrontación. Aprenderemos de los europeos. Combatiremos el terrorismo con las herramientas que nos da el Estado de derecho44.

Os terroristas de esquerda são tidos como remanescentes constrangedores do passado: do tempo da revolução, da luta de classes, da confrontação. O Chile atual, aquele que por meio de eleições diretas decidiu a favor da democracia, tinha de ser uma sociedade do consenso. A imagem a ser construída e projetada era a de uma nação que, cansada de anos de acirrado confronto político, resolvia a favor da exclusão política dos nãoreconciliados 45 .

No Chile, autoridades militares de alta patente entenderam a crise de segurança como oportunidade política e ofereceram ao executivo ajuda para a captura dos frentistas 46 . Na avaliação da instituição castrense, o ataque era um passo prévio à consolidação da guerra de guerrilha, diagnóstico elaborado na lógica da doutrina de Segurança Nacional47. A oferta foi recusada, preferindo-se a estratégia civil de controle, vigilância e erradicação do

44 Entrevista concedida por Patricio Aylwin ao jornal alemão Die Welt em 15 de abril de 1991. Entrevista recuperada do arquivo digital "Archivos Públicos" da Universidade Alberto Hurtado. Disponível em: https://bit.ly/2UxwYfx. Acessado em: 12 de novembro de 2018.

45 Expressão cunhada pelo cientista político Robert Meister (2011) para nomear as que se recusavam a aceitar os termos e procedimentos políticos, bem como os princípios éticos da justiça transicional, que inclusive chegaram a pautar o campo internacional dos direitos humanos, na década de 1990.

46 Frentistas era o termo usado pelo regime de Pinochet e pela imprensa hegemônica para se referir aos militantes do FPMR. Já Rodriguistas era a forma pela qual chamavam entre si os próprios militantes e as publicações mais à esquerda do espectro político.

47 Acerca dessa estratégia, ver reportagem "Plan Abril. La secreta ofensiva del Ejército contra el terrorismo”, publicada na Revista APSI, maio, XVI, 1991. 
terrorismo dito revolucionário (Otano, 1995). "Respetando la democracia, sin incurrir en violencia, sin matar a nadie, sin torturar, sin ninguna de las cosas que se estaba acostumbrado en dictadura" - com tais palavras, Belisario Velasco, subsecretario do Ministério do Interior no governo de Aylwin, descrevia, em meados de 2014, a desarticulação dos grupos subversivos nesses anos 48 .

A chegada de especialistas civis para o Ministério do Interior e o Ministério da Defesa foi possível graças ao desprestígio das instituições policiais e militares, considerando a responsabilidade que lhes couberam na violação dos direitos humanos no regime ditatorial. A criação de um organismo de inteligência encabeçada por civis foi uma questão prioritária: a nova administração devia se apropriar dos espaços vinculados à segurança interna antigamente dominados pelos militares (Hathazy, 2013). Assim, ganharam espaço e poder profissionais, vários deles cientistas sociais altamente qualificados que, na década de 1980 , trabalharam para prestigiados centros de estudos e universidades, tanto no Chile como no estrangeiro, bem como em espaços acadêmicos que atuavam como focos de oposição ao regime de Pinochet49. Na avaliação dessa elite tecnocrata (Aggio e Cáceres, 2000), era urgente abandonar a Doutrina da Defesa Nacional, transformação fundamental para a modernização e a democratização das instituições policiais, locais onde deveriam ser priorizados novos paradigmas, como o policiamento comunitário (Hathazy, 2013; Ramos e Guzmán, 2000; Risør, 2018).

Para a identificação e perseguição política dos grupos de extremaesquerda, o mandatário designou um pequeno grupo de renomados militantes do Partido Socialista e da Democracia Cristã para dar vida a esse corpo assessor, que seria responsável por entregar diretrizes políticas e técnicas para a luta democrática antiterrorista (Farfán, 2006; Mella, 2014;

\footnotetext{
48 Entrevista radial com Belisario Velasco, na rádio Futuro, 10 de setembro de 2014. Áudio de entrevista disponível na íntegra em: https://bit.ly/2YERfBZ Acessado em: 12 de novembro de 2018.

49 Entre eles, Corporación de Estudios para Latinoamérica (CIEPLAN), Faculdade LatinoAmericana de Ciências Sociais (FLACSO), Corporación de Estudios Sociales y Educación SUR, Centro de Estudios del Desarrollo (CED) e o Instituto Latinoamericano de Estudios Transnacionales (ILET).
} 
Rosas, 2013). Mario Fernández, democrata cristão, advogado que voltou do exilo com uma tese de doutorado na Universidade de Heidelberg sobre a doutrina da Segurança Nacional nas ditaduras latino-americanas5o, aliás, passou a ser Subsecretário de Aviação do Ministério de Defesa no governo de Aylwin, tendo sido o escolhido para ser presidente dessa nova repartição. Jorge Burgos, filiado ao mesmo partido, que, na década de 1980, desempenhou a função de professor de direito na Universidade do Chile, chegaria a ser chefe do gabinete do Ministro do Interior e diretor do Conselho Antiterrorista. Marcelo Schilling, da cúpula do Partido Socialista, que, com o codinome de "Gastón", na década de 1970, atuou no grupo paramilitar encarregado da proteção do presidente Salvador Allende (GAP-Grupo de Amigos Personales del Presidente), contou com treinamento militar em Cuba, formado em ciências jurídicas e econômicas durante o exilo no México; além de ser designado Subsecretário do Ministério de Desenvolvimento Regional, atuou como secretário executivo do conselho de segurança. Todos eles, nos posteriores governos da Concertación de Partidos por la Democracia, continuariam na primeira linha governamental ocupando cargos como ministros nas áreas de Defesa e do Interior, ou como embaixadores e/ou parlamentares. Em outras palavras, aqueles que idealizaram e lideraram as políticas de neutralização do terrorismo nos alvores da redemocratização, durante mais de duas décadas, dirigiram o país. A eles, ainda, seguia uma segunda camada de militantes recrutados menos por suas credenciais acadêmicas e mais por seus conhecimentos empíricos e técnicos acerca da guerra de guerrilhas, bem como pela proximidade com os grupos armados, como os analistas Antonio Ramos51, Óscar Carpenter e Lenin Guardia, todos militantes socialistas.

50 A tese de Mario Fernández intitula-se Nationale Sicherheit in Lateinamerika. Ihre ideologische und legitimierende Funktion bei der Errichtung von Militärregime seit 1964, e foi defendida, em 1981, na Universidade de Heidelberg, na Alemanha.

${ }^{51}$ Conforme Juan Cristóbal Peña (2019), Antonio Ramos, quem teve treinamento militar em Cuba, além de trabalhar no conselho de segurança, trabalhava no Ministério Secretaria General de Governo, especificamente, na Secretaria de Comunicações e Cultura no governo de Aylwin. Lenin Guardia, sociólogo, integrante da GAP, no exilo, esteve a cargo da segurança de Carlos Altamirano, máximo dirigente do Partido Socialista. Óscar Carpenter, por sua vez, também foi militante do GAP, com treinamento militar em Cuba, na Alemanha Oriental e com participação na Nicarágua. 
Ainda que essa repartição não tenha tido jurisdição para desenvolver atividades operativas e avançar na desarticulação dos "grupos violentistas", suas atividades certamente não se restringiram à redação de relatórios, informes estatísticos e análise de fontes abertas. Sem existir informes oficiais sobre a dita dimensão do trabalho acometido, sabe-se, por declarações de militantes e ex-funcionários, assim como por reportagens jornalísticas da época, que o conselho mantinha uma rede de informantes pagos, composta por militantes e ex-militantes da FPMR e do Mapu-Lautaro, como foi o caso de Agdalín Valenzuela e Domingo Sarmientos, ambos, anos depois, mortos por companheiros de militância, acusados de traição (Rosas, 2013)52.

\section{Um informe de inteligência}

Um mês depois de recebida a carta de Joana no Conselho Coordenador da Segurança Pública, os funcionários anexaram-na ao ofício protocolado, redigido ao Ministro do Interior, Enrique Krauss. O memorando informava da denúncia com a assinatura de Hugo Frühling, advogado especialista em direitos humanos, justiça transicional e, logo depois, em segurança pública que hoje é diretor de um importante centro de pesquisas da Universidade de Chile. Antes de se doutorar em direito pela Universidade de Harvard, em 198453, Frühling desempenhou um cargo, entre 1978 e 1981, em um dos mais destacados organismos na defesa dos direitos humanos de presos políticos, ligado à igreja católica, chamado Vicaría da Solidaridade54. Até 1986, publicou uma série de trabalhos acadêmicos em direitos humanos e justiça transicional para a FLACSO e a Universidade de Humanismo Cristiano, entre outras instituições.

\footnotetext{
52 A eles, teriam se juntado informantes permanentes, como o ex-militante do MIR e da FPMR, Humberto López Candia, e o sociólogo Lenin Guardia - ambos condenados, em 2002, por infração à lei antiterrorista por envio de carta bomba à embaixada dos Estados Unidos em Santiago.

53 Tese doutoral de Frühling, Derecho y Sociedad. Transformación Social y Crisis Jurídica en Chile.

54 Esta importante instituição deu fim às suas atividades em 1992; afinal, na democracia, não teria mais sentido dedicar-se à defesa de presos políticos, assumindo que já não haveria mais presos por perseguição política.
} 
Em novembro de 1988, deu-se lugar um importante encontro de acadêmicos e ativistas organizado pelo Aspen Institute e financiado pela Fundação Ford, a fim de discutir como governos em transição democrática iriam lidar com os crimes do passado (Arthur, 2009). Pretendia-se refletir, coletivamente, as implicações políticas, éticas e morais das distintas formas em que a justiça estava sendo entendida na Argentina, Guatemala, Uganda, Coréia do Sul, Brasil, África do Sul e Filipinas. Como lidar com os demônios e fantasmas do passado? O encontro, paradigmático para a conformação do campo da justiça transicional, contou com a participação de dois chilenos: José Zalaquett, advogado, exilado na ditadura, com renomada trajetória no campo dos direitos humanos, que integrou a Comissão da Verdade e da Reconciliação. Junto com el, participou, também, o jovem Hugo Frühling, que, mesmo sem ser expositor, prestigiou como audiência o importante evento internacional (Arthur, 2009).

Frühling, especialista em justiça de transição e direitos humanos, passou a trabalhar como assessor do Ministério do Interior, mais especificamente no Conselho Coordenador da Segurança Pública. Em entrevista concedida a Hathazy (2013), o advogado recorda de sua participação no conselho antiterrorista. Naquela ocasião, estimou necessário participar de um campo que causava "alergia" na esquerda. Atividade temporal e part-time (também prestava serviços para o Centro de Estudios del Desarrollo, um importante think tank ligado ao governo), sua função limitava-se à coleta de informações da polícia, a organizar reuniões e à análise de fontes abertas. Nesse sentido, desconhecia as atividades de infiltração acometidas pelos agentes e informantes que trabalhavam para o Conselho Coordenador da Segurança Pública. A carta de Joana, no entanto, complica um pouco essa narrativa, aparentemente consolidada. Ele assinou o relatório que informava as atividades de seguimentos em terreno. Talvez isso fosse algo sem importância, um infame relatório esquecido pelo prestigiado acadêmico que, depois, iria se converter em um acadêmico especialista na modernização das instituições policiais chilenas.

No acervo do período presidencial de Aylwin, entre os documentos emitidos por esse analista de segurança, há atas de reuniões com encarregados da inteligência policial, informes sobre terrorismo internacional (especificamente, sobre o Partido Comunista do Perú-Sendero Luminoso e a 
Organização para a Libertação da Palestina - OPL), bem como o recebimento de cartas de cidadãos que, assim como Joana, reportavam atos terroristas. Estes últimos obedeciam às constantes chamadas do governo para denunciar qualquer tipo de atividade subversiva.

O informe de inteligência redigido por Frühling diz55:

\title{
MEMORANDUM RES. 098.
}

3 de Enero de 1993

\author{
A: $\quad$ SR. ENRIQUE KRAUSS R. \\ MINISTRO DEL INTERIOR \\ DE: HUGO FRÜHLING E. \\ SECRETARIO DEL CONSEJO COORDINADOR DE SEGURIDAD PÚBLICA
}

Un estudio preliminar de la denuncia presentada por la Srta. Joana L., permite llegar a la seguintes conclusiones:

1. La Srta. L. registra antecedentes penales por infracción a la ley de drogas. Fue encausada en dos oportunidades en 1979 , siendo absuelta en una de las causas.

2. La Sra. M., madre de la denunciante, explicó que su hija tiene serios problemas psiquiátricos y que desde muy joven ha consumido drogas, razones por las cuales ha debido ser hospitalizada en diversas oportunidades. Ella estima que los problemas síquicos de su hija son los que la hacen realizar este tipo de denuncias.

3. Se constató que la denunciante, tiene problemas con drogadictos del sector.

4. No existe evidencia de la veracidad de sus acusaciones en materia de subversión o terrorismo. Se seguirá insistiendo en ello.

5. En principio, es posible concluir que las acusaciones vertidas por la denunciante no revisten un grado de seriedad que las haga reales.

Atentamente,

Hugo Frühling E.

Em uma linguagem descritiva e breve, sem muitos detalhes dos procedimentos concretos de vigilância, o memorando parece obviar tudo aquilo que descrevi no início deste capítulo, a saber: as distorções, os elementos fantásticos e fantasmagóricos, os erros evidentes da versão

55 Informe recuperado do arquivo digital "Archivos Públicos" da Universidade Alberto Hurtado. Mudei os nomes, as datas e os números de arquivo, para não comprometer os envolvidos. 
defendida pela mulher. Então, como entender essa aparente assepsia e neutralidade a respeito da denúncia paranoica de Joana? Se o Estado e as polícias defendem a sua atuação como eficiente e racional, seguir a pista de Joana parece tudo menos isso. No campo do policiamento da política, nota-se uma mistura entre a apresentação de si, neutra e tecnocrata, e os desbordes, a sofreguidão e os excessos - neste caso, o desejo ansioso de que os ditos de Joana fossem reais e conseguissem, finalmente, desarticular a FPMR. Nada poderia ser desconsiderado. Assim, o doutor de Harvard estimou em algum grau razoável o relato de Joana para informá-lo ao ministro56.

O informe da inteligência emitido sobre o caso de Joana é expressivo do que Hélène L'Heuilliet chamou de "alta polícia”, uma polícia política que faz da delação, do segredo e da infiltração técnicas privilegiadas para a produção de regimes e efeitos de verdade: a "polícia das sombras" (L'Heuillet, 2004, p.16). O informe, criado para circular de forma restrita, como documento reservado, mas que décadas depois viria à luz ao ser incluído no acervo digitalizado dos arquivos do governo de Patricio Aylwin, contrasta com esse outro documento, o informe colossal da verdade e da reconciliação, registro de uma política "nobre", liderada por uma elite moral escolhida pela sua imparcialidade no sentido de estabelecer nada mais nada menos que a verdade histórica. Um era um documento secreto; o outro, um documento divulgado na televisão pelo próprio mandatário da nação. Diferentes na fabricação, nas audiências e no prestígio, mas que na sua disparidade absurda testemunham os diferentes caminhos percorridos na transição democrática chilena para alcançar a dita paz social57.

É na conjuntura política da revelação do Informe Rettig e da repressão do terrorismo de esquerda que o relato de Joana, aquele que fala de radares, máfias, lavagem cerebral e nazistas, foi considerado pelos especialistas em

\footnotetext{
56 A trajetória de Frühling, em certa medida, lembra a análise proposta por Adalton Marques (2017) do caso brasileiro sobre Sergio Adorno: de especialistas em direitos humanos e sua defesa para a questão da segurança pública na redemocratização, apresentado, a partir desse caso, o papel dos cientistas sociais que lutaram pela defesa dos direitos humanos no projeto de modernização das instituições de controle social na democracia. Contudo, no caso analisado por Marques, a questão do terrorismo mal aparece.

57 Tal qual proposto por Mark Neocleous (2010), entendo segurança e pacificação como elementos concatenados na produção da ordem liberal e a manutenção do capital.
} 
contra-insurgência como pista que podia contribuir para a captura de líderes frentistas. Na persecução criminal dos subversivos, o Conselho Coordenador da Segurança Pública deu início a inquéritos para corroborar as informações recebidas; foi assim que, de modo um tanto quanto paradoxal, as fantasias de perseguição de Joana se tornaram reais. A "presença espectral do estado" (Aretxaga, 2003, p.44), corporizado na figura de agentes civis ou policiais (não sabemos ao certo ainda), projetou-se sobre o corpo de Joana, circundando o seu espaço íntimo: sua casa, seu bairro e sua família. Finalmente, ela se encontrava perseguida, não por terroristas, mas sim por agentes da inteligência. Como rememorava em 2014 um dos homens mais influentes no campo da segurança pública chilena, o democrata cristão Belisario Velasco, subsecretário do Ministério do Interior de Aylwin, nos primeiros anos da redemocratização do país, para desarticular o terrorismo, o Estado acolhia informações e denúncias de qualquer pessoa ${ }^{8}$.

\section{Expurgar a violência, odiar a dialética}

O processo de transição chileno apresentou-se, pelo menos publicamente, como uma empreitada apolítica. Em favor da nação, as diferenças ideológicas e partidárias deviam ser apagadas. Das vítimas, por outro lado, exigia-se a capacidade de "perdoar" a quem lhes havia causado dor: deviam ser vítimas "civilizadas", generosas e tolerantes com a capacidade de expurgar de si a raiva, o ressentimento e os desejos de vingança (Risør, 2018, p. 278).

Para conseguir a paz, entre a justiça e a verdade, no Chile, deu-se prioridade à segunda: a verdade se constituiria como resposta para se chegar à reconciliação. Ainda que o informe da Comissão da Verdade e Reconciliação tenha sido um gesto coletivo de compromisso com a verdade histórica, a justiça foi deixada como questão a ser resolvida de forma particular entre as famílias dos desaparecidos, os executados políticos e o sistema penal chileno (Bengoa, 1994). Por outro lado, a permanência na esfera pública e no governo

58 Entrevista radial realizada com Belisario Velasco, entrevista em rádio Futuro, 10 de setembro de 2014. Áudio disponível na íntegra em: https://bit.ly/2YERfBZ. Acessado em: 12 de novembro de 2018 . 
democrático de figuras responsáveis pelos horrores, como o próprio Pinochet, assim como de políticos que ampararam o extermínio, foi explicada pelas lideranças da redemocratização não como impunidade, mas sim como expressão da civilidade e da maturidade do povo chileno, da sua tolerância e vontade de reconciliação. Por sua vez, a convivência entre vítimas e beneficiários do horror do passado era evidência do desejo da nação para priorizar o consenso e a moderação, virtudes éticas e políticas do Chile pósditadura (Risør, 2018).

A distância das consignas clamadas pelos movimentos sociais ("ni perdón, ni olvido"), uniformados, civis e elites que perpetraram atos de violação dos direitos humanos e/ou se beneficiaram dos horrores do passado, foram protegidos pela lei. Defesa dos direitos humanos vis-à-vis proteção dos culpáveis e encarceramento de rebeldes - processo não exclusivo desse país. Para superar o passado, o ódio e a vingança, elementos corrosivos e que alimentavam a espiral da violência, deviam ser expurgados: sarar a nação, empreitada ético-política encarada de frente por países como a África do Sul, a Argentina e a Guatemala, algo que implicava uma higienização moral e política (Wilson, 2003).

Para além desses elementos, eu adicionaria a consolidação de um pretenso discurso apolítico que, no fundo, soava como algo próximo a um anticomunismo. Nisso, houve sim consenso nacional: as elites políticas e tecnocratas, a igreja católica e os militares concordaram com o expurgo no país de todo sinal da dialética marxista. Nessa medida, a dialética conflitiva nada podia contribuir para um país que pretendia se reconciliar consigo mesmo e que, apesar das mortes, apreciava os benefícios legados pela modernização neoliberal implementado na ditadura - que deixaram uma economia em estabilidade institucional, sobretudo quando comparada ao resto dos países latino-americanos. Ainda, era preciso recordar, assinalavam outros, que o Golpe de Estado de 1973 sobre Salvador Allende foi a resposta difícil, ainda que necessária, aos excessos promovidos pela luta de classe e a pretendida revolução socialista liderada pela Unidade Popular. Assim, agora, no presente democrático, prudência, reconciliação, estabilidade e paz social deviam ser os valores orientadores da nação, questão que foi discutida nesses exatos termos também em outros países em via de redemocratização, juntamente com a defesa do livre mercado e da propriedade privada (Arthur, 
2009). Assim sendo, no Chile, instituiu-se uma transição gradual, reformista e consensual que se apresentava a si como devota da calma e da razão (Mella, 2014) - termos, aliás, próximos do processo de redemocratização no Brasil59.

Nesse cenário, Patricio Aylwin preocupou-se que sentimentos tais como o ódio e a raiva chegassem a atrapalhar o processo transicional. Em seu primeiro discurso de 21 de maio, data que, por tradição, os presidentes chilenos apresentam ao congresso seus avanços, o ex-mandatário discorreu sobre o imperativo moral de se recusar toda forma de violência e terrorismo em prol da paz social. Nesse caminho, justiça e verdade aparecem como elementos fundamentais; portanto, os eventos passados, mesmos cruéis e dolorosos, não podiam ser mais ignorados. No entanto, para acabar com a "espiral da violência” (metáfora recorrente em sociedades pós-ditatoriais), era crucial implementar campanhas para inocular nos jovens pobres o amor pela democracia, bem como a recusa moral da violência política. Nesse "novo amanhecer" do país, teria de ficar para trás a cultura da morte6o promovida tanto por marxistas revolucionários quanto por militares: os primeiros, via a luta de classe e o ódio à burguesia; os segundos, via uma doutrina macarthista antimarxista.

Depois de décadas de conflito político, chilenas e chilenos teriam de aprender a avaliar com os mesmos critérios toda violência, venha de onde vier, revolucionária ou reacionária. Para enfatizar tal ponto, em um exercício parecido ao realizado por Joana, o democrata cristão colocava lado a lado diferentes episódios de violência ocorridos entre 1970 e 1990:

Hay en esta materia [violência] una especie de maniqueísmo inmoral y dañino. Para unos, todo crimen es obra de revolucionarios marxistas-leninistas; para otros, quienes los cometen son siempre aparatos represivos al servicio de intereses reaccionarios. La experiencia demuestra lo contrario. ¿Fueron acaso los mismos los

59 Refiro-me à expressão do ditador Ernesto Geisel, no Brasil, sobre um processo de redemocratização "lento, gradual e seguro".

6o Cultura da morte foi uma expressão disseminada pelo papa João Paulo II. Sendo Aylwin do partido da Democracia Cristã, não estranha sua aparição no discurso presidencial. 
asesinos del general Schneider y de Edmundo Pérez61? ¿Fueron los mismos los asesinos del general Prats62, de Orlando Letelier, del general Urzúa y del coronel Fontaine? ¿Son los mismos que atentaron contra el general Pinochet63, los que mataron a Tucapel Jiménez, los que intentaron asesinar a Bernardo Leighton o los que atentaron contra el general Leigh64? ¿Son los mismos los que asesinan carabineros y los que degollaron a Parada, Guerrero y Nattino65? (Aylwin, 1992, p. 34).

Como indicado no início do capítulo, a Comissão da Verdade e Reconciliação em seu informe oficial, equiparou a violência dos aparelhos repressivos da ditadura, sistema massivo de extermínio, com os ataques minoritários perpetrados por militantes de esquerda contra policiais, militares e políticos da direita. Ambas as violências foram categorizadas como violação dos direitos humanos. Estabelecer tal simetria, escolha apresentada como meramente técnica, tinha um evidente componente político: responsabilizar a

61 O ex-ministro Edmundo Pérez Zukovic, democrata cristão, foi morto em 1971 em ato de "ajusticiamiento" pelo grupo Vanguardia Operaria del Pueblo (VOP). O ministro foi considerado pelos seus victimários o responsável político pela morte de 9 pessoas por ação policial, em 1969, na cidade Puerto Montt, em uma reintegração de posse. O general do Exército, René Schneider, foi morto em Santiago, em 21 de outubro de 1970, por militares em coordenação com a agência de inteligência americana, a CIA.

$62 \mathrm{O}$ ex-comandante em chefe do Exército, Carlos Prats, foi morto em um carro bomba em Buenos Aires, no dia 30 de setembro de 1974, ato acometido pela polícia política de Pinochet, a DINA. Os militares Carlos Urzúa e Luis Fontaine foram mortos, respetivamente, em 30 de agosto de 1983, por militantes do MIR, e em 10 de maio de 1990, por militantes da FPMR.

63 Refere-se ao atentado da FPMR contra Pinochet em 7 de setembro de 1986, e ao assassinato do dirigente sindicalista Tucapel Jimenez, em 25 de fevereiro de 1982, por integrantes da Dirección de Inteligencia Nacional del Ejército (DINE).

64 O democrata cristão Bernardo Leigthon, exilado na Roma, sofreu um atentado em 6 de outubro de 1975, como parte da Operación Cóndor. Já o caso do ex-general Gustavo Leigh, integrante da Junta Militar que derrocou Allende em 1973, foi o 21 de maio de 1990, quando pessoas mascaradas chegaram até o seu escritório e atiraram nele, que foi salvo com vida. Dois grupos assumiram a autoria do evento: militantes da FPMR-Autônoma e uma tal de Frente de Resistencia Nacionalista, suposto grupo de extrema-direita desconhecido.

65 Conhecido como o "Caso Degollados". Em 30 de março de 1985, os corpos de Santiago Nattino, Manuel Guerrero e José Parada, militantes do PC chileno, apareceram mortos em Santiago, ação perpetrada por agentes da Dirección de Comunicación de Carabineros do Chile. 
ambos os "extremos" das violências passadas. Chegar a tal consenso não foi difícil para a comissão, que não incluiu nenhum político militante nos partidos de esquerda reprimidos pela ditadura. Para estabelecer a verdade histórica, nesse sentido, foram convidadas figuras da centro-direita, quase todas, como Aylwin, eram militantes da Democracia Cristã 66. Dada essa composição, não é de estranhar que o termo militante "terrorismo de Estado", cunhado para dar conta da repressão e vulneração da população civil em grande escala, fosse banido do repertório conceptual do Informe Rettig. Terrorismo, ao contrário da tendência internacional, foi reservada pela comissão para dizer respeito a subversivos militantes da "extrema-esquerda".

A decisão de chamar os agentes repressivos do Estado e os militantes de esquerda, indistintamente, de "violadores dos direitos humanos" é um contrassenso. No Chile, como no resto do Cone Sul, a questão dos direitos humanos foi pautada, em grande medida, pela luta de organizações civis que atuaram na defesa dos presos, executados e desaparecidos nas ditaduras que assolaram a região entre 1960 e 1980 - muitos deles, acusados pelos aparelhos repressivos de serem subversivos terroristas. O Informe Rettig reconheceu que no debate internacional não se empregava o termo "violação dos direitos humanos" para descrever ataques letais perpetrados por atores civis. Entre os organismos internacionais, o termo estava destinado a descrever os crimes cometidos pelo Estado, sempre tendo em vista o grau, a escala e a magnitude dos recursos empregados institucionalmente na vulneração dos direitos mais elementares da população civil.

A decisão técnica da Comissão da Verdade e Reconciliação se sustentava em supostas crenças e valores do povo chileno. Primeiro, pressupunha que muitos chilenos temiam que a esquerda manipulasse $o$ discurso acerca dos direitos humanos, reconhecendo vítimas oriundas de

\footnotetext{
66 Os convocados para integrar a comissão foram: Raúl Rettig, Jaime Castillo Velasco, José Luis Cea, Mónica Jiménez, Ricardo Martin, Laura Novoa, Gonzalo Vial, José Zalaquett e Jorge Correa, sete dos quais eram advogados. Acerca da composição política do grupo, a maioria era próxima da Democracia Cristã, embora houvesse também figuras próximas do regime pinochetista, como Gonzalo Vial, que foi Ministro de Educação, em 1978. A participação de Vial foi amplamente criticada por setores da esquerda, mas ela pode ser entendida dentro das "negociações" da transição, que mantiveram o ditador no poder, como irei detalhar mais à frente.
} 
apenas um dos lados e ignorando os excessos acometidos por seus militantes - lógica que desvalorizava a vida dos uniformados e políticos de direita assassinados. Acolhendo tal opinião, que se dizia na época permear a sociedade chilena, a comissão preferiu evitar que a condição de vítima terminasse sendo um monopólio moral da esquerda. Segundo, e novamente apelando à nação, se dizia que na consciência nacional: "se ha hecho carne la ideia de que existen ciertos valores de humanidad que deben ser respetados no solamente por el Estado, sino por todos los actores políticos" (Informe Rettig, vol. 1, 1992, p. 19).

O próprio Informe Rettig reconhecia que, entre os especialistas, evitava-se catalogar as ações de civis como violação dos direitos humanos porque tal diagnóstico era, não poucas vezes, usado por regimes autoritários na defesa de seus crimes. A repressão a civis era justificada pela necessidade de defender a nação dos ataques perpetrados por adversários políticos, a saber, os terroristas que vulneravam (eles sim, e não os ditadores) os direitos humanos. Esse, por certo, foi o caso de Augusto Pinochet. Em seus discursos da década de 1980 , enquanto protestos populares contra o regime multiplicavam-se nas ruas de Santiago, o ditador discorria sobre a ameaça, já não subversiva, mas terrorista. Se desde 1974, seguindo a Doutrina da Defesa Nacional e da contra-insurgência, subversivo era a palavra mais utilizada pelo general, na década seguinte ganhou espaço no repertório lexical de Pinochet o termo terrorismo. Em 198167, argumentando em defesa da democracia e dos direitos humanos (sim, o ditador falando nestes termos), Pinochet anunciava uma "guerra sin cuartel" contra os "terroristas marxistas", minorias violentistas treinadas no exterior e que buscavam impor o caos ao país. Nesse combate, se acionariam todos os mecanismos jurídicos disponíveis para "extirpar" de vez esse mal que pretendia, nada mais nada menos, que destruir "o sistema da vida cristã ocidental”, problema que afetava vários países nãocomunistas.

O general convocava os chilenos a se oporem à doutrina marxistaleninista que exaltava a luta de classe e a violência, ideologia que dividia o país e que tinha de ser "proscrita" da vida cívica nacional. Com isso, criticava os protestos de rua que começaram a ocorrer principalmente em Santiago

67 Ver: PINOCHET, A. Mensaje Presidencial , 11 de setembro de 1981. 
exigindo o fim do regime de facto. Para o ditador, os manifestantes buscavam a destruição dos direitos fundamentais e a implementação do totalitarismo socialista no país. Nesse discurso, Pinochet aproveitava para recordar Roger Vergara, diretor da escola de inteligência do exército que havia sido assassinado por militantes do MIR, em 15 de julho de 1980, homenageado como mártir da instituição castrense. Tanto os protestos massivos como os atentados individuais confirmavam os perigos que trazia a "politização da vida nacional".

Em 198368, Pinochet continuaria a falar de terrorismo; em seu discurso anual, dedicaria palavras à memória de Carol Urzúa, ex-general do exército e prefeito de Santiago, assassinado em 29 de agosto de 1983, junto com mais dois uniformados, José Aguayo e Carlos Rivero, em ação levada a cabo pelo MIR. Era a paz social o que esses grupos, inseridos em redes internacionais e com apoio de agentes comunistas soviéticos, pretendiam destruir: buscavam acabar com a soberania chilena, atacando o "lo más sensible del alma nacional”. À memória de Urzúa ergueram-se monumentos e ruas foram batizadas com o seu nome em Santiago. Ainda houve atos espontâneos de recordação, como o organizado por um grupo de jovens universitários que, no lugar do atentado, fizeram um discurso onde clamavam: a "lacra do terrorismo" deve ser combatida com todo o peso da lei. Grupos terroristas, apoiados pelo PC chileno - partido "ateu e imoral" -, deviam ser "marginalizados" da via política (Silva, 2014, p. 214). Naquele ato, os manifestantes pró Pinochet, em performance iconoclasta, procederam a atear fogo em uma réplica da bandeira do MIR. Quem costurou a bandeira? Como decidiram se aquele artefato era suficientemente real? No final das contas, o que se viu foi a duplicação de símbolos dos inimigos para a sua imediata destruição69.

A respeito da responsabilidade do comunismo internacional na onda de protestos daquela época, Pinochet continuaria a discorrer no discurso

68 Ver: PINOCHET, A. Mensaje Presidencial, 11 de setembro de 1983.

69 $\mathrm{Na}$ verdade, houve uma bandeira falsa queimada; mas, três anos antes, uma outra bandeira verdadeira foi roubada: em 30 de março de 1980, militantes do MIR, fantasiados com perucas e bigodes, roubaram do Museo de Historia Nacional a bandeira usada no juramento de independência nacional em 1818, importante ícone do mundo militar chileno. 
anual de 198670. Os manifestantes eram "fanáticos" comunistas, alguns deles organizados em "células" treinadas no exterior para matar militares e policiais chilenos. Nem a defesa da democracia, nem dos direitos humanos eram propósitos das mobilizações multitudinárias, e sim a busca da "desintegração anárquica" do Chile. Os protestos constituíam a primeira fase da subversão no cenário urbano. Em vista disso, a Alianza Democrática, que foi um conjunto de partidos e movimentos sociais organizados em prol da defesa da democracia, era no limite uma "aliança antidemocrática", além de antipatriótica, pois às ordens do marxismo internacional - ironizava o ditador.

Nesse ano de 1984, foi promulgada a nova lei de condutas terroristas que veio a concretizar o posicionamento do regime a respeito do conceito de terrorismo enquanto atividade, por definição, revolucionária: "Son conductas terroristas las acciones $u$ omisiones constitutivas de un crimen o simple delito, realizadas para crear conmoción o grave temor en la población o en un sector de ella o ejecutadas mediante actos atroces crueles, con un fin revolucionario subversivo" - estipulava a primeira versão encaminhada pelo poder executivo.

A apropriação do discurso dos direitos humanos pelas falas de Pinochet tem sido interpretada como "falácia argumentativa" (Villegas, 2016). O Estado invoca os direitos humanos para defender a ordem e o Estado do potencial ataque de grupos terroristas - e não, como deveria ser, para a proteção dos cidadãos dos excessos da violência estatal. De tal modo, via inversão lógica (não muito diferente, aliás, do exercício realizado por Joana), os violadores dos direitos humanos justificavam a repressão na chave da defesa dos direitos humanos: "Terrorismo en cualquiera de sus formas es por esencia contrario a los derechos humanos" - assim ficou consagrado na carta fundamental de 1981. Se o governo era acusado de terrorismo de Estado, agora, em movimento contrário, essa palavra seria reservada para quem pretende atacar a ordem e a paz social: eles, os terroristas; nós, os antiterroristas.

Um dos principais ideólogos do regime militar, o advogado Jaime Guzmán, morto em 1992 por militantes da Frente Patriótica Manuel Rodriguez, discorria também sobre o terrorismo: "estoy contra de todo exceso

7o Ver: PINOCHET, A. Mensaje Presidencial , 11 de setembro de 1986. 
en relación a los derechos humanos, sea del terrorismo marxista o de los desbordes de su combate" (Guzmán, 2014, p. 159). Guzmán, militante do partido conservador União Democrata Independente (UDI) e paroquiano da seita Opus Dei, aprofundava: os terroristas não são doentes mentais; por detrás dos ataques, há cérebros muito lúcidos a serviço de um "mal moral" que defende utopias antinaturais bem como totalitarismos políticos. São mentes que propagam "uma ideologia do ódio" - referindo-se, por certo, ao marxismo e à luta de classes (Guzmán, 2014).

Nesse quadro geral de culpabilizar a dialética marxista e a luta de classes dos conflitos e das violências políticas, podemos acrescentar os ditos do João Paulo II na sua visita ao Chile, em 198571. Em grande evento, que ocorreu em 3 de abril no Parque O'Higgins, a máxima autoridade católica na época elogiou a "naturaleza pacífica del pueblo chileno" e a sua propensão à concórdia. Violência e terrorismo, exclamava, deviam ser condenados sem importar a vertente política. O pontífice convocava o povo a deixar para trás a "dialéctica inhumana de la lucha de clases" - a qual desconhece no outro, chamado de inimigo de classe, um irmão ${ }^{72}$. A autoridade religiosa chamava a se afastar dessas lógicas belicosas e demonstrar que o povo chileno preferia o diálogo e a compreensão ao conflito violento. Enquanto fazia esse convite no palco, os assistentes ao evento, mais de 500.00o, exibiam cartazes denunciando as torturas que ainda aconteciam no Chile. Grupos minoritários de manifestantes - com seus rostos ocultos com lenços - lutavam com pedras contra a polícia de choque, que chegou a reprimir os protestos.

A mensagem de João Paulo II foi rapidamente adotada pela Democracia Cristã, partido que passou a liderar a Alianza para la Democracia. Gabriel Valdés, ex-ministro no governo de Eduardo Frei Montalva (1965-1970) e um dos mais renomados militantes do partido, que havia retornado do exilo, em evento político, em 21 de novembro daquele mesmo ano, também no Parque O’Higgins (que iria a ser chamado, prometia o político, Parque dos

${ }_{71}$ Discurso de João Paulo II, em 3 de abril de 1987. Discurso recuperado do arquivo digital "Archivos Públicos" da Universidade Alberto Hurtado. Disponível em: https://bit.ly/ 2OK8EFp. Acessado em: 20/09/2018.

72 Chama a atenção que o pontífice não clamou contra o terrorismo da extrema-direita: em maio de 1981, na Praça San Pedro, ele próprio recebeu um disparo de um jovem turco, Mehmet Ali Agca, que teria motivações políticas de extrema-direita. 
Direitos Humanos, algo que nunca aconteceu), pedia para desterrar a lógica dos inimigos, da guerra e da dialética. Recuperava, ainda, a expressão cultura da morte - termo usado por João Paulo II para defender a cultura da vida, seja em relação à defesa da democracia e dos direitos humanos ou à crítica da legalização do aborto73. Valdés chamava a repudiar o terrorismo e receber o "advento" da paz. A ideia de espiral de violência também aparece na sua narrativa, entendida como "contra-violência" e "vingança". Não perdeu a oportunidade para dizer, ainda, algo sobre como era fundamental deixar as ideologias no passado no passado, sobretudo aquelas posições políticas responsáveis de levar o país a extremos - fazendo referência ao governo da Unidad Popular: "ese lujo, lo hemos pagado demasiado caro"74.

A aproximação entre terrorismo, defesa dos direitos humanos e anticomunismo que tentei esboçar aqui, ao meu ver, se adequava às orientações promovidas pela política exterior dos Estados Unidos. Entre os governos de Jimmy Carter e Ronald Reagan, por exemplo, houve uma reorientação em matéria da defesa dos direitos fundamentais que impactou sobremaneira as alianças internacionais do "bloco não comunista". No entendimento da equipe de Reagan, o governo cartista assumiu uma visão ideal e purista dos direitos humanos que pretendia esfriar as relações com governos que estivessem violando os direitos políticos de suas populações, afastando potenciais aliados na luta contra a URSS. Ao contrário, muito mais

73 João Paulo II, em conferência do episcopado em Santo Domingo, em 1992, declarava: "La vida, desde su concepción en el seno materno hasta su término natural, ha de ser defendida con decisión y valentía. Es necesario, pues, crear en América una cultura de la vida que contrarreste la cultura de la muerte, la cual - a través del aborto, la eutanasia, la guerra, la guerrilla, el secuestro, el terrorismo y otras formas de violencia o explotación - intenta prevalecer en algunas naciones (Terrorismo y Abortos: en IV Conferencia del Episcopado Latinoamericano en 1992, en Santo Domingo. p.1992, p.27). Assim sendo, terrorismo e aborto (cuja legalização estava sendo discutida na Itália) eram equiparados enquanto violações dos direitos humanos, ideia, aliás, que fora recuperada por Jaime Guzmán, artífice da constituição chilena, que ainda rege o país e que criminaliza o aborto em qualquer condição. "Estoy cierto que más temprano que tarde, el mundo occidental se avergonzará del verdadero genocidio que la legislación abortista permite y estimula. Surgirá entonces una condena a este fenómeno, similar a la que suscitan los genocidios de Hitler y Stalin" ("Un cristiano, un rey y un hombre”. Artigo em jornal La Tercera, 22 de abril de 1990). Disponível em: https://bit.ly/ 2kjPBDr. Acessado em: 20/03/2019.

74 Discurso completo em Revista Hoy, 25 de novembro 1985, p.11-13. 
de que se os governantes respeitavam ou não os direitos humanos, o que importava eram quais países, mesmo os não democráticos, contribuíam com os Estados Unidos na luta anticomunista a nível internacional.

Nos últimos anos da Guerra Fria, a agenda americana da defesa dos direitos humanos passou a ser homologada à luta contra o terrorismo. Assim sendo, a palavra terrorista foi pouco a pouco transformada em sinônimo de governos totalitários, quer dizer, daqueles que se recusavam a adotar os valores da democracia liberal ocidental: como todos os aliados da URSS, como Cuba, China, Coreia do Norte, Moçambique e Angola. Já no caso dos governos autoritários, entre eles os latino-americanos impostos por meio de golpes de Estado financiados pelos Estados Unidos, conforme a definição dos estadunidenses, eram governos que, ainda que não democráticos, exibiam uma adesão aos princípios da liberdade de mercado, afinidade com princípios morais norte-americanos e um compromisso na luta anticomunista. Portanto, os apoios e as lealdades deviam se manter com os ditadores.

Nesse movimento estratégico, a defesa dos direitos humanos seria redefinida como a luta contra o totalitarismo comunista e a defesa da liberdade (Carleton; Stohl, 1985; Kundnani, 2014). Assegurar o direito às liberdades políticas da população seria opcional, à diferença da defesa da liberdade económica, que era direito inviolável o qual os Estados deviam assegurar (Chamayou, 2018). Tal lógica pode ser notada na frase do renomado economista liberal, Friedrich Hayek, que declarou a respeito da ditadura chilena: "pessoalmente, prefiro um ditador liberal que um governo democrático sem liberalismo”75.

\section{A neutralização dos não-reconciliados}

A vitória eleitoral de Patricio Aylwin se deu no contexto da queda do Muro de Berlim e daquilo que Samuel Huntington chamou de "Terceira Onda de Democratização”, ocorrida em países da América Latina, Europa do

75 Frase de Hayek recordada por Chamayou em entrevista à Carta Capital em o9/12/2018. Disponível em: https://bit.ly/2LhyUSD. Acessado em: 11/o2/2019. 
Leste e África ${ }^{6}$. Naquela nova ordem mundial, os que lutaram contra os regimes autoritários que incluíram a violência em seus respectivos repertórios de ação não podiam ser mais vistos como combatentes, menos ainda como heróis: seriam catalogados como violadores dos direitos humanos, na medida em que, na defesa de seus ideais utópicos, haviam vulnerado a vida de outros.

Portanto, a rejeição da violência como recurso político no decorrer da década de 1980 aconteceu paralelamente ao debate acerca da necessidade da denúncia da violência de regimes totalitários de cunho socialista. Para Michel Wiervorka (2009), os debates sobre a legitimidade da violência se extinguiram paralelamente à exaustação das utopias comunistas pós-1989 e aos processos de desindustrialização, no caso da Europa. Os grupos armados, como as Brigadas Armadas que continuaram falando de violência revolucionária e de luta de classes, eram expressão, no entender desse autor, de uma "violência cega e demente" sem justificativa dadas a situação atual. Ou seja, tratava-se de discursos e práticas ancorados em ideologias do passado que não podiam ser mais defendidas. Nesse raciocínio, o golpe de Estado contra Salvador Allende, a morte de Che Guevara na Bolívia, a derrota das guerrilhas, tudo se juntava para constatar que a revolução não era mais uma opção (Arthur, 2009).

No Chile, para avançar na reconciliação nacional, os demônios e os fantasmas precisavam ficam para trás, sitiados no passado. Nesse contexto, a tendência era para uma "desradicalização" dos movimentos sociais à medida que o discurso dos direitos humanos ganhava relevância nas políticas de memorialização. No Chile, junto às críticas dos partidos de centro, a esquerda, que passou grande parte da década de 1960 e 1970 discutindo sobre a efetividade da via revolucionária ou eleitoral (Palieraki, 2014), afastouse da utopia dos câmbios estruturais. Assim, por exemplo, o Partido Socialista Chileno dos anos 1990 (uma divisão daquele que havia levado Allende ao poder) transformou-se no partido do status quo: afinal, estabilidade e ordem

\footnotetext{
76 Esse termo é de uso corriqueiro na academia chilena para falar da redemocratização do país. A periodização global proposta por Huntington dá início a essa terceira onda, com a saída de Salazar, em 1974, em Portugal, e o retorno da democracia no Equador, em 1979, e na África do Sul, em 1994, com a eleição de Mandela.
} 
eram seus maiores princípios orientadores, conservando uma fobia explícita ao conflito (Mella, 2014)77.

Além da questão da violência, os processos de redemocratização apresentados, como o triunfo do liberalismo e a defesa dos direitos fundamentais, colocaram o dilema das vítimas e a conseguinte despolitização da matriz dos direitos humanos. Aqueles que sofreram a violência dos regimes autoritários, agora reconhecidos como vítimas da violação dos direitos humanos, não seriam mais compreendidos como sujeitos com direito de se insurgirem: só poderiam ser resgatados por intermédio de intervenções humanitárias. Seriam proibidas a esses a busca da justiça e a autodefesa: era a vitória liberal da não-violência, único comportamento político aceitável para os atores civis ${ }^{78}$. Em tal cenário, seja no Chile ou na África do Sul, a história foi reduzida à memória, a opressão à vitimização, sendo que esta última deixou de ser fonte de luta em prol de mudanças sociais radicais para converter-se em categoria técnica onde as vítimas passaram a ser definidas como beneficiárias de reparações monetárias do Estado.

No Chile, como já foi discutido, os gestores da verdade transicional buscaram deliberadamente responsabilizar a ambos os extremos políticos dos horrores do passado. Em pretensa parcimônia, defendia-se a "lógica do empate", da corresponsabilidade nos excessos de intolerância e de

77 Digo dos anos 1990 porque o PS Chileno sofreu várias rupturas internas na década de 1970 e no decorrer da ditadura de Pinochet, até se reunificar em 1990. Para mais informações a respeito, ver: Muñoz (2016).

78 Eyal Weizman (2017) tem discutido a consolidação político-moral do humanitarismo no Pós-Guerra Fria e sua relação com a empreitada anticomunista liderada pelos Estados Unidos. A atuação de organizações como Médicos Sem Fronteiras, com seu foco na compaixão e piedade para com as vítimas promoveu uma lógica que já não colocava no cerne do conflito as relações entre a burguesia e o proletariado, mas sim entre vítimas e perpetradores da violação dos direitos humanos, deixando estes últimos em uma posição passiva e quase que religiosa. A contradição ainda passou do capital-trabalho para democracia-totalitarismo, sendo as máximas a serem seguidas a liberdade e a segurança. As valas comuns que apareceram em diversos cantos do mundo nos anos 1990 levaram à questão de se pensar na dor e crueldade humana como algo a resolver, para além das mudanças políticas estruturais. Hoje, o dispositivo humanitário, que incorpora desde leis internacionais sobre direitos humanos até ONGs transnacionais, é constituído de tecnologias morais, um marco para a aplicação, o cálculo e a gestão da violência militar sobre os deslocados, inimigos e indesejados do planeta. 
desrespeito à vida humana. Ao mesmo tempo, negava-se qualquer legitimidade da atuação passada de organizações políticas de esquerda, sobretudo aquelas que incluíram entre as suas táticas de resistência e seus repertórios de ação política a violência armada. Isto tudo, claro, com o propósito de excluir qualquer possibilidade de se justificar a continuidade dessas formas de fazer política após a vitória eleitoral de Aylwin. Era essa a preocupação que começou a despontar nos últimos anos da ditadura no Chile à luz dos protestos populares contra a ditadura.

Particularmente, nas ciências sociais, a questão da violência política, não a do Estado, mas a performada por civis, foi contabilizada, categorizada e explicada especialmente por sociólogos. Os riscos postos pelas militâncias mais disruptivas deviam ser avaliadas, haja vista o perigo que ditas forças sociais não aceitassem a desmobilização e continuassem na via da violência depois de recuperada a democracia. Nesse campo de produção acadêmica é que irrompe o termo "terrorismo": objeto de estudo, de intervenção e, claro, de policiamento79.

\section{Isolando terroristas}

No mesmo ano em que Joana encaminhava a sua carta ao Ministério do Interior, 1992, Hugo Frühling, o doutor em direito pela Universidade de Harvard, que além de secretário do Conselho Coordenador de Segurança Pública ocupava o cargo de secretário do Consejo Latinoamericano de Investigaciones para la Paz, publicava, junto com Myram Waiser, "La Violencia en Contra del Estado de Chile: 1976-1991", artigo onde os dois comentavam possíveis estratégias antiterroristas a serem seguidas no país. Vários dos assuntos analisados no texto já tinham sido tratados em documentos emitidos pelo conselho de segurança para auxiliar o executivo na tomada de decisões para enfrentar o que devia ser chamado, sem hesitar, de "terrorismo"

\footnotetext{
79 Como constatação desta tendência, em 1987, na cidade de Viña del Mar, realizou-se o $1^{\circ}$ Congreso Iberoamericano de Facultades de Derecho y Especialistas sobre Terrorismo y Estado de Derecho - evento organizado pela Universidade Central e a Faculdade de Ciências Políticas da Universidade do Chile -, do qual participaram mais de 30 acadêmicos chilenos e estrangeiros. Alguns dos papers apresentados foram publicados na Revista de Sociologia da Universidade do Chile, no dossiê intitulado "Estudios sobre Terrorismo", em 1988.
} 
e "ações terroristas". Em documentos oficiais, tais como "Apuntes para el Tratamiento del Orden Público y Delincuencia8o", "Reunión sobre Delincuencia, Violencia y Terrorismo81", e "Pacto Nacional Contra el Terrorismo ${ }^{82 "}$ - só para citar alguns textos publicados entre 1990 e 1991 -, são três as ideias fortes: despolitizar, isolar e integrar os não-reconciliados.

Primeiro, se apontava a urgência de reconhecer publicamente a existência de grupos terroristas no Chile, questão nada simples considerando o peso que teve esse termo no regime ditatorial. Como iriamos também nós, democratas, falar de terrorismo, mesmo termo usado pelo ditador para justificar a repressão? Os assessores convocavam a todos a deixar para trás qualquer pudor. Na democracia, terrorismo não era mais que uma categoria técnica, neutra, esvaziada de clivagem política particular, amplamente usada em debates acadêmicos e legislativos para dizer respeito à violência política. Outros termos queridos da esquerda, tais como "guerrilheiros", "militantes" e "combatentes", não seriam mais adequados para pensar um país que ansiava por recuperar a paz. Teria que se evitar, portanto, qualquer "romantização" da violência revolucionária. Ordem pública e Estado de direito eram os princípios a salvaguardar, portanto, a responsabilidade do governo era prevenir e castigar qualquer ato terrorista que colocasse em risco a paz social. Nenhum privilégio ou tratamento especial haveria para quem acometesse este tipo de ato, sem importar qualquer justificativa política. Na democracia,

8o Texto do Conselho Coordenador de Segurança Pública, sem data. Recuperado do arquivo digital "Archivos Públicos" da Universidade Alberto Hurtado. Disponível em: https://bit.ly/ 2YT6Vog. Acessado em: 03/12/2018.

81 Memorando de reunião do gabinete presidencial sobre crime, violência e terrorismo, em 19 de março de 1990; Recuperado do arquivo digital "Archivos Públicos" da Universidade Alberto Hurtado. Disponível em: https://bit.ly/2MN1QVc. Acessado em: 08/01/2019.

82 Rascunho do Pacto Nacional acerca do Terrorismo, criado em 3 de abril de 1993. Recuperado do arquivo digital "Archivos Públicos" da Universidade Alberto Hurtado. Disponível em: https://bit.ly/33fzbO5. Acessado em: 07/01/2019. 
ainda, e isto é fundamental, não haveria mais presos políticos: todos os presos seriam iguais, criminosos condenados 83 .

Segundo, as mudanças lexicais formavam parte de uma estratégia maior: o isolamento político e moral dos terroristas. Para tanto, era essencial que todos os atores políticos, tanto os opositores como os aliados do governo, de forma mancomunada, rejeitassem a violência como forma de ação política. $\mathrm{Na}$ democracia, existindo canais institucionais de participação, nada justificava a violência. $\mathrm{O}$ isolamento político implicava, também, esforços para quebrar quaisquer vínculos existentes entre os próprios militantes das agrupações terroristas, assim como as conexões entre estes e outras organizações sociais e partidos políticos. $\mathrm{O}$ isolamento dos rebeldes iria no sentido do trabalho comunicacional de negar qualquer conteúdo político nos atos terroristas, sendo recomendado tratá-los, simplesmente, como "delitos comuns”.

Porém, nesse quesito, havia divergências. No início da transição, havia a preocupação de tratar os fenômenos, "crime" e "terrorismo", como equivalentes por uma razão técnica: publicações acadêmicas afirmavam que, no primeiro ano da democracia, o terrorismo tinha aumentado - isto, sobretudo, porque se utilizavam, para justificar tal premissa, estatísticas sobre assaltos com armas ${ }^{84}$. Na década de 1980 , as "expropriações" a supermercados, bancos e depósitos de armas foram parte do repertório de ação de grupos como a FPMR, o MIR e o Mapu Lautaro. Por essa razão, existia a tendência a associar extremismo com assaltos armados. Em documento do Ministério do Interior, se afirmava o contrário: nos primeiros anos do governo, houve uma queda do terrorismo político e uma reconversão

\footnotetext{
83 Esta foi, inclusive, a estratégia de Margaret Tatcher para lidar com os rebeldes do IRA, ainda que este caso não tenha sido considerado como referência por ideólogos da transição chilena: "There is no such thing as political murder, political bombing or political violence. There is only criminal murder, criminal bombing and criminal violence". Discurso em Belfast, 5 de março de 1981: https://bit.ly/2ZIo76U. Acessado em 05/01/2019.

84 Os assessores do presidente discutiam o artigo "Hipótesis del Terrorismo: una metodología de análisis aplicado al caso chileno (1983-1993)", do sociólogo Milan Marinovic, publicado em 1987. O sociólogo, especialista em forças armadas, trabalhou no regime de Pinochet nas áreas de inteligência da Armada Naval. Na democracia, iria desempenhar o cargo de professor na área de engenharia na Universidade de Santiago.
} 
desse fenômeno para o que foi chamado de "terrorismo anárquico ou delinquencial" - executado por pessoas que não podiam sair da "inércia violentista" do passado. As fronteiras porosas entre ilegalidades colocavam-se como um desafio para as autoridades estatais que desejavam demonstrar que os grupos terroristas estavam, efetivamente, sendo erradicados.

Paralelamente à preocupação com o terrorismo, incrementaram-se os discursos sobre a criminalidade comum. Mediante ações concertadas de vários think tanks, da imprensa e de setores políticos da direita, cresceu um sentimento de medo da delinquência. $\mathrm{O}$ inimigo, aos poucos, deixava de ser o terrorista de esquerda, assumindo a face do criminoso jovem e popular, que emergia como ameaça onisciente e omnipresente. De tal forma, ganhou centralidade na década de 1990 na agenda política a dita "luta contra os criminosos". Apesar das baixas taxas de homicídios no Chile, o país começou a aparecer nos primeiros lugares de rankings latino-americanos que ponderavam "o medo da violência", paradoxo que foi bastante estudado pela academia chilena nos anos 2000, indagando as relações entre imprensa, ideologia e fobia. É importante notar que esse processo se deu em paralelo com a tendência global para tematizar o crime enquanto uma preocupação pública central e a necessidade de securitização como princípio orientador da política (Wacquant, 2012; Roca, 2018).

"En la lucha por lograr la adhesión de la población, están siendo más eficaces los terroristas" 85 - diagnosticava um informe policial ao analisar um ataque com artefato explosivo de baixa intensidade a uma delegacia de polícia em um bairro popular de Santiago, em 16 de março de 1991. No geral, não eram os danos menores o que preocupava as autoridades, mas o apoio da população a esse tipo de episódio: baixa disposição para a denúncia e proteção dos perpetradores logo depois dos ataques. Por essa razão, era necessário buscar fórmulas para a deslegitimação de práticas violentistas e ganhar a adesão às políticas antiterroristas. Esse tipo de ataque era interpretado como tática de "assédio moral", assim como ato que deixava em

85 Informe da Dirección de Inteligencia de Carabineros do Chile, março 1991 
evidência a incapacidade das polícias de impedir assaltos, concluía o informe ${ }^{86}$.

O isolamento político dos rebeldes nos primeiros anos da democracia, por certo, incluiu o debate sobre os regimes carcerários a serem implementados para os condenados por condutas terroristas. Se analisaram, para tanto, modelos utilizados na Itália, na Alemanha e na Espanha, onde se segregavam fisicamente os terroristas dos presos comuns, sempre com base na ideia de que a convivência diária podia contaminar os presos comuns com ideias subversivas e contribuir para a sua organização no interior dos recintos carcerários. O modelo da cela individual e do banheiro próprio apareceu como a solução técnico-política para lidar com esse risco. Depois de visitas de políticos e especialistas chilenos nos Estados Unidos e na Europa, incluindo o próprio ministro Enrique Krauss, em 1994, se inaugurou em Santiago a Cárcel de Alta Seguridad (CAS), recinto onde foram realocados os internos condenados durante os 4 primeiros anos da democracia por "infrações" terroristas, vulneração da segurança interna e da paz social. "Ellos tendían a usar las propias instalaciones de la cárcel como una oficina para programar y planificar los actos terroristas de sus compañeros que estaba en el exterior" assim explicava o arquiteto e subdiretor da Gendarmeria do Chile naqueles anos, Claudio Martínez ${ }^{87}$. Daí a necessidade da segregação desses internos.

A essas medidas, o Conselho Coordenador de Segurança Pública promoveu, ainda, a discussão sobre as medidas legislativas que deviam ser desenhadas para o policiamento específico dos "não reconciliados". A delação compensada, inspirada na experiência italiana, foi proposta e implementada. Os militantes que buscavam desertar de suas organizações, à medida que entregassem informações valiosas ao governo, poderiam passar a receber benefícios, tais como a diminuição do tempo das condenações, além de ter acesso a bolsas de estudos e postos de trabalho. Essas medidas, conforme aparece nos informes emitidos pelos conselheiros, buscavam maneiras de pensar a reintegração social dos arrependidos. Nesse quadro, a entrega de informações sobre militantes e possíveis atentados passaria a ser interpretada

\footnotetext{
86 Ataques à polícia, seja a agentes ou a prédios da instituição, não deixariam de ocorrer no futuro, sendo hoje parte do repertório de protestos, como veremos no capítulo seguinte.

87 As declarações podem ser lidas em Farfán (p.2006, 71).
} 
pelos organismos de controle e repressão como contribuição real para a paz social e para a estabilidade da democracia. Patricio Aylwin, democrata cristão, em documentos da época, expressava sua preocupação com esse assunto da reintegração. Os terroristas, dizia ele, eram parte da sociedade: estudaram em nossas escolas, eram integrantes de nossas famílias. Ou seja, os reconhecia como um inimigo interno e íntimo. Portanto, ainda que tivessem debandados para a violência deveriam ter espaços reservados na sociedade.

Porém, não há registro sobre o funcionamento dessas medidas integradoras, tampouco o número de pessoas que entraram em supostos programas de reinserção, menos ainda sobre militantes que operaram como informantes do governo - exceto Agdalín Valenzuela, integrante da FPMR, supostamente morto por colaborar com o governo delatando companheiros. "La transición navegó por aguas procelosas. No fue un camino pavimentado con pétalos de rosas. Yo sé que a la familia le cuesta aceptarlo [negam que ele foi informante], pero Agdalín fue clave para que cruzáramos el charco"88 rememorava, em 2015, Marcelo Schilling, militante do PS Chileno e integrante do Conselho de Coordenação de Segurança Pública ${ }^{89}$.

Nos procedimentos descritos por esses documentos oficiais e técnicos acerca da gestão da subversão, há depoimentos de quem foi perseguido por essa agência de segurança sobre métodos menos neutrais e adequados à democracia: a disseminação de rumores teria sido uma estratégia para causar conflitos entre os militantes das organizações que se buscava desarticular. Conforme a pesquisa de Rosas (2013), corriam boatos a respeito de dezenas de militantes que supostamente estariam entregando informações ao governo enquanto informantes. Tratava-se de informações deliberadamente falsas que pretendiam quebrar as redes de confiança entre os militantes e, com efeito, promover a suspeita e paranoia entre eles, assim como a sensação de que podiam estar sendo vigiados por pessoas do entorno próximo.

\footnotetext{
88 Entrevista publicada no jornal La Tercera, 11 de outubro de 2015. Disponível em: https:// bit.ly/2M7pBaG. Acessado em: 06/01/2019.

89 Agdalín Valenzuela, com 30 anos, foi morto a tiros por desconhecidos em Curanilahue, no sul do Chile, em 11 de outubro de 1995. Os rumores dizem que foi "ajusticiado" por excompanheiros de militância, culpado de ser delator (Peña, 2019).
} 
Por outro lado, no corpus de textos produzidos pelos assessores, também se encontram os que discutiam a relação entre segurança e mercado. O dito "terrorismo de esquerda" precisava ser controlado não só pela questão da ordem interna, com pela necessidade de manter os mercados interessados em investir no país 90 . O jurista Ángel Flisfisch, subsecretario do ministério da Secretaria Geral da Presidência, hoje diretor da Faculdade Latino-americana de Ciências Sociais (FLACSO-Chile), no texto "Problema del Terrorismo", datado de 18 de março de 1991, propunha estratégias comunicacionais que pretendiam informar permanentemente o país a respeito dos avanços no combate ao terrorismo, a fim de propiciar um ambiente de confiança entre a população e o funcionamento da economia. Seguindo a linha dos informes acima resenhados, era preciso assumir que o problema do terrorismo existia, sim, e que era tão importante como a inflação, o crescimento econômico ou a equidade social. Em tal contexto, a definição oficial do terrorismo devia ser estritamente policial, judicial e ético. Logo, considerações sociológicas sobre a sua origem, seja ela na desigualdade social seja no passado autoritário do país, não eram questão do governo.

Assim como a inflação, e isto que asseverava era o assessor, o terrorismo era um "flagelo" a ser atacado de frente pela nova democracia chilena. Isso devia ser feito mediante uma comunicação institucional clara e transparente, evitando ambiguidades sobre as autorias dos atentados - isto se dizia fazendo referência à suspeita de que, nos primeiros anos da redemocratização, os ataques poderiam ter sido perpetrados por pessoas próximas ao regime militar, que buscavam desestabilizar o novo governo em matéria de segurança. Com isso, insistia Flisfisch, politizava-se um assunto que não devia ser politizado. Alertava, por fim, que a violência devia ser rejeitada, seja de onde viesse. É terrorismo e ponto final. Tal era o único fato que devia importar ao governo. Nesse mesmo sentido, as autoridades políticas deviam evitar qualquer intento por historicizar o fenômeno - por exemplo, dizendo que se tratava de uma violência que havia surgido do ódio, da raiva e do terrorismo de Estado vividos durante a ditadura. "Estas fórmulas de inmediato evocan un complejo afectivo lleno de contradicciones que debilitan credibilidad" - alertava. A única questão política a se reconhecer

9o Documento recuperado do arquivo digital "Archivos Públicos" da Universidad Alberto Hurtado. Disponível em: https://bit.ly/2KAdEaw. Acessado em: 02/02/2019. 
publicamente sobre o terrorismo é que era um fenômeno que atacava a segurança e a democracia chilena.

\section{O funeral do marxismo}

Nas transmissões televisivas que ocorreram durante o mês anterior ao Plebiscito Nacional de 1988, a campanha da Concertación de Partidos por la Democracia (campanha pelo "NO") trouxe uma narrativa de renascimento e concórdia que teve como símbolo principal um arco-íris e um slogan: "Chile, la alegría ya viene”. O propósito era transmitir tranquilidade e confiança aos eleitores para que participassem, sem receios, de uma votação realmente livre e sem segredos. Ainda que alguns dos capítulos da campanha tenham trazido testemunhos sobre os desaparecidos e feito menção ao exilo e à tortura, a ênfase esteve na renovação, esperança e paz. Depois de décadas de militares liderando o país, naquele momento eram jovens vestindo roupas coloridas e dançando músicas vibrantes que convidavam os telespectadores a mudar o futuro do país.

As propagandas pela continuidade de Pinochet (campanha pelo "SÍ"), ao contrário, se organizaram ao redor do medo e da violência. Diziam eles que votar pela oposição era voltar ao período da Unidade Popular, à instabilidade financeira e à pobreza. Era retornar a tempos quando o mais básico dos "direitos humanos", o direito ao pão, havia sido perdido por culpa de Allende e seus aliados. Eleger Pinochet por mais 11 anos era dizer sim a um "país ganador", como cantado no jingle oficial. Ganhador, em um duplo sentido: país que venceu o comunismo e país moderno que se abriu sem medo aos mercados globais. Nesse contexto, o risco do comunismo sintetizou-se na figura do terrorista. Em vez de alegria, para os militares, o plebiscito era entendido na chave da guerra: "Es bueno que ciertos políticos se den cuenta de que estamos en guerra. La alternativa es marxismo y caos o democracia” explicava aos telespectadores o ditador vestido com um rigoroso uniforme cinza. Episódio no qual, ainda, ele dava seu testemunho pessoal como vítima do terrorismo, ao sobreviver, junto ao seu neto, de um ataque cometido pela FPMR, em 1986. A moral do marxismo, complementava outro capítulo da campanha, era o caos, a destruição e a morte, termos que eram superpostos a 
imagens de arquivo de protestos de rua, fogo, barricadas e escaramuças com a polícia - e, por certo, de mascarados.

A campanha pelo "NO" teve rápido sucesso, assinalando uma possível vitória. A popularidade dos adversários forçou a direita a reorientar a sua estratégia comunicacional: resolveram, então, seguir o caminho da paródia. As pessoas por trás da criatividade da vídeo-campanha pelo "SÎ" apropriaram-se dos símbolos dos adversários e os distorceram de forma burlesca. Simulando a filmagem da campanha rival, mostravam um set televisivo onde um grupo de jovens dançava alegremente em frente ao slogan do "NO". Nessa imitação, a câmera se deslocava para um plateau contíguo. No fundo branco e com pneus no chão, aparece um homem que seria o diretor do vídeo do "NO", vestido um poncho91 e dando broncas em um grupo de dançarinos que havia chegado tarde na filmagem: “Oye, pero a la hora que vienen llegando po!”. Tais jovens, que imitam os dançarinos do "NO", não chegaram com seus maiôs e leggings, e sim com balaclavas e carregando coquetéis Molotovs. "Es que teníamos que hacer otra cosa antes po"92 - respondem zombeteiros, enquanto um deles tira seu casaco e une-se à coreografia, ainda mascarado. "Vamos a decir que no/yo lo canto sin temor/vamos a decir que no/todos juntos a triunfar/vamos a decir que no/ por la vida y por la paz" - escuta-se, até que, no instante em que a palavra "paz" é dita, há um close-up na figura do mascarado e uma voz em off masculina alertando devagar aos telespectadores: "Marxista vestido de seda, marxista queda" - enquanto que o terrorista marxista se faz de envergonhado.

Esses falsos democratas, como os chamava Augusto Pinochet, em vez de alegria e paz, pretendiam para o país o totalitarismo comunista e o horror. O mascarado dançando no meio do plateau, paródia política com finalidades publicitárias, era uma mixórdia de signos deturpados que revelavam um excesso, um elemento impróprio que deveria ser motivo de riso, de bom humor.

91 Músicos renomados como Victor Jara e Quilapayún transformaram o poncho em símbolo político da esquerda.

92 Vídeo pelo "SI" disponível em: shorturl.at/oCMY3. Acessado em: 09/01/2019. Visualizar a partir do minuto o1:11. 

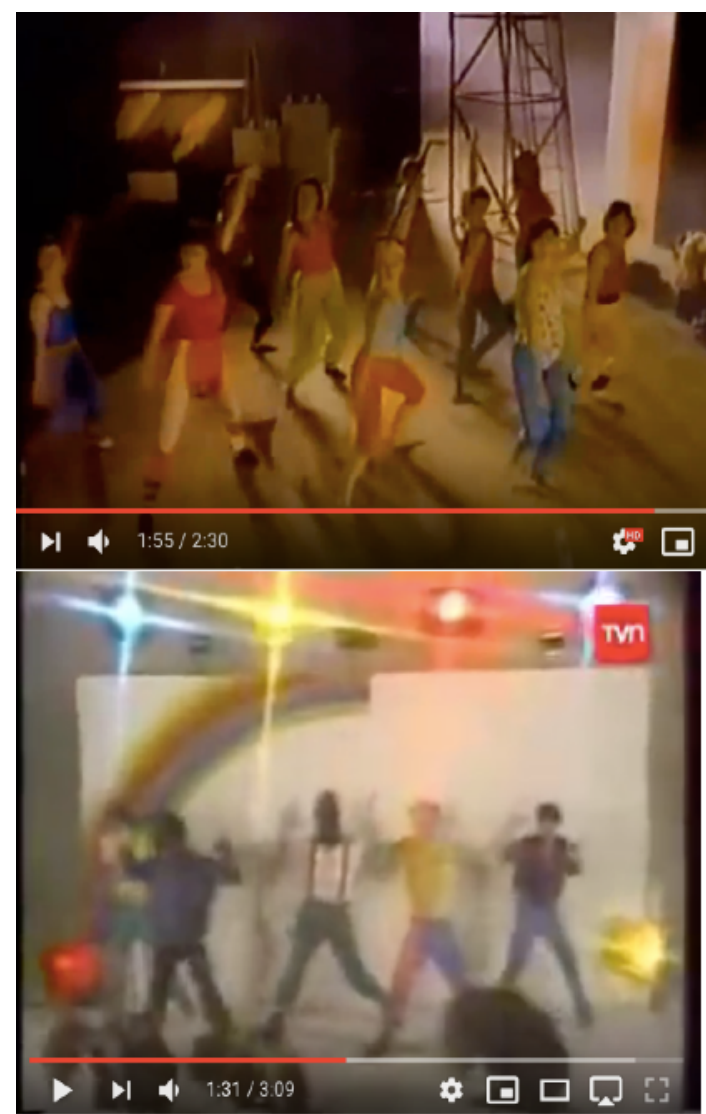

Figuras 4 e 5: Campanha pelo Plebiscito (Youtube, 1988)

Fantasias terroristas não foram encenadas pela direita só dessa vez. Em 23 de abril de 1988, ainda no contexto do plebiscito, um grupo de militantes da Avanzada Nacional (AN) reuniu-se no centro de Santiago. O partido próPinochet foi fundado em 1983 com o objetivo de mobilizar aderentes contra os multitudinários protestos em oposição ao regime militar iniciados nesses anos nas principais cidades do país (DÍAZ, 2016). Entre seus princípios, além do apoio incondicional ao ditador, se declaravam nacionalistas e humanistas, democráticos e populares, por certo, superando as distinções esquerda/ direita. Ao mesmo tempo, embora entre seus militantes estavam alguns dos líderes da polícia secreta pinochetista, diziam recusar da violência como recurso político: "Rechazo absoluto del violentismo, expresado bajo las formas del terrorismo y de la subversión marxista, ajenos a nuestra pacífica voluntad de convivencia nacional”. De participação errática e esporádica, foi para o plebiscito que voltaram à cena política.

Esse dia de abril, no centro de Santiago, um grupo de correligionários carregou cartazes com as iniciais do partido, AN, cujo símbolo parecia uma 
insígnia com as cores da bandeira chilena. É possível saber desse episódio porque há uma sequência de três fotos guardadas no arquivo de Fortín Mapocho, uma importante revista opositora da época. Foi por acaso que, buscando imagens de funerais de figuras políticas, interessada nas parafernálias utilizadas durante os cortejos de militantes mortos na ditadura, cheguei às perturbadoras fotografias. Mas o que faziam esses mascarados portando armas no centro da cidade, em um ambiente que, em vez da tristeza esperada de um funeral, os fazia rir a gargalhadas? O evento se chamava "Funeral Simbólico del Marxismo", o que esclarecia o inusitado episódio93.

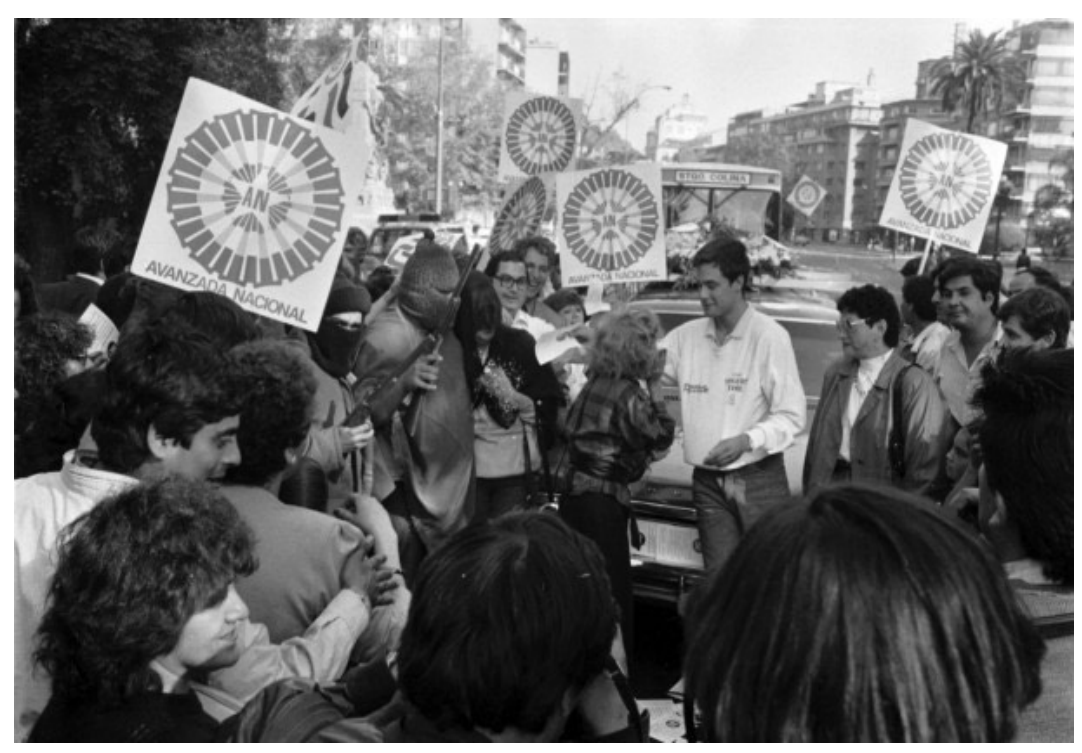

Figura 6: Funeral Fictício, (Fortín Mapocho, 1985)

Atente-se para o casal na centro-esquerda da Figura 6: um homem de balaclava e arma em mãos abraça uma mulher que carrega um ramalhete de flores e leva o rosto semioculto por um véu à moda antiga. $\mathrm{O}$ corpo dela aparenta um corpo em dor: levemente encolhido, se resguardando nos braços do homem a seu lado. Há uma segunda mulher, que é de fato o foco da fotografia, que de alguma forma diz a um jovem de camisa branca, que parece tentar abraça-la: "o que você está falando?". As mãos perto de seu rosto transmitem uma fala afetada pelo sofrimento. No final das contas, essa é a encenação de um funeral. Essas personagens fictícias zombam da dor das

$93 \mathrm{Na}$ verdade, não há mais informações desse evento para além da série de fotografias capturadas pelo fotógrafo de Fortín Mapocho, Pablo Castillo, que resolveu dar esse nome às legendas que acompanhavam as imagens. 
mulheres que, no decorrer da ditadura, participaram dos funerais de seus filhos, maridos, irmãos, amigos, executados políticos e desaparecidos.

Nos ritos fúnebres da esquerda, por questões de segurança, não era estranho que os participantes resolvessem mascarar-se. Para a polícia, os funerais subversivos eram uma chance única onde aqueles em clandestinidade poderiam se ver tentados de participar da despedida de seus entes queridos. Ali, entre flores e caixões, as redes de parentesco e amizade serviam para ratificar redes "extremistas". É assim que balaclavas e outras prendas, como lenços para cobrir o rosto, passaram a fazer parte da parafernália militante mortuária, além das bandeiras do MIR ou da FPMR. Esses funerais, não poucas vezes, terminavam com a polícia lançando gases lacrimogêneos, espancando os participantes e prendendo os enlutados.

Uma imagem poderosa desses enfrentamentos fúnebres é a do funeral de Rodrigo Rojas Negri, jovem de 19 anos - e que, em 2 de julho de 1986, depois de dois meses de voltar do exilo com sua mãe, foi queimado vivo por militares, acusado de erguer barricadas em protestos contra Pinochet. Seu corpo juvenil, como se não tivesse bastado a crueldade do fogo, agora, transmutado em cadáver, foi seguido por agentes da polícia dentro do Cemitério Geral de Santiago. A Figura 6 mostra o carro enfeitado de flores a levar o caixão do Rodrigo indo por entre uma névoa tóxica, defendido por um homem só, de camisa branca e cabelos pretos curtos, deitado sobre o carro em movimento, com sua mão que acena aos policiais: chega!

O funeral-réplica de 1988 imita esse tipo de sofrimento, não para solidarizar, mas sim para o ridiculizar a dor do outro. Na Figura 6, há olhares cúmplices e curiosos entre os assistentes que seguram os risos: não era comum de se ver, em pleno centro de Santiago, tranquilamente, "terroristas" mascarados! O riso dos participantes potencializa o desconcerto. É o punctum, como definido por Roland Barthes: detalhe pungente na composição fotográfica que faz dela uma imagem inquietante porque nos fere, nos amortiza como se fosse uma ferida (Fontanari, 2015). A falsa bandeira do MIR queimada por universitários da direita, o funeral burlesco e o dançarino-terrorista são atos públicos de apropriação e inversão dos símbolos do "outro" inimigo, o "terrorista de esquerda", mimeses e parodia que se edificam em nome da luta contra-insurgente e em prol da paz social. 
Paródia e humor, nesses casos, servem para alertar sobre os riscos do retorno do comunismo no país: o marxismo, simplesmente, devia ser enterrado no fundo da terra, tal como milhares de marxistas (ou acusados de o serem) foram de fato escondidos embaixo da terra em lugares que ainda não sabemos. Corpos desaparecidos que algumas mães ainda buscam entre as pedras do deserto, como nos ensinou o diretor Patricio Guzmán em seu triste documentário Nostalgia da Luz (2010). Corpos sumidos à força por serem vistos como elementos infecciosos, foco de contágio para a nação chilena. É com esse funeral paródico, inquietante e - por que não? - infeliz que caminho para o segundo capítulo desta tese, que irá se iniciar com mais um funeral "subversivo", desta vez real. Com ele, adentraremos o outro lado da trincheira: dos corpos rebeldes e das memórias combativas.

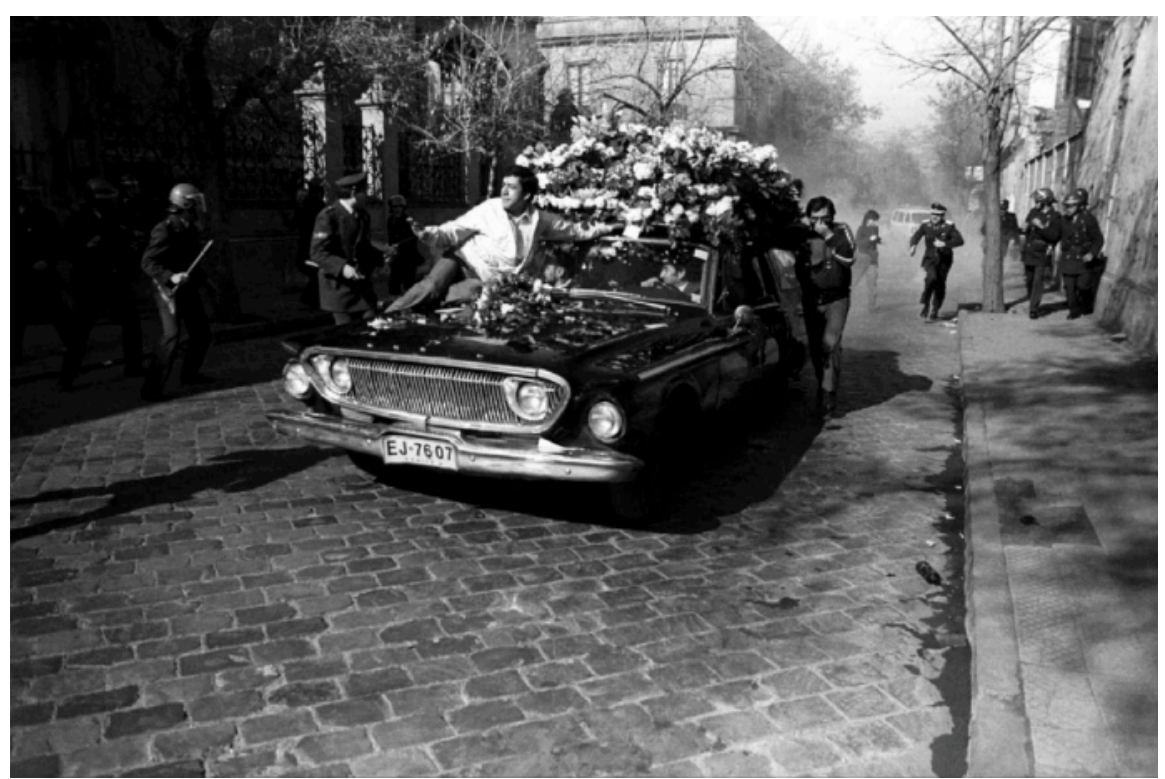

Figura 7:

Funeral de

Rodrigo Rojas

(Hoppe, 2013) 


\section{CAPÍTULO 2 \\ De mortos, ruas e mascarados}

\section{Tênis, camiseta e calça jeans}

Domingo, 30 de março de 1985. Três mil pessoas marcham pelo centro de Santiago. A procissão avança devagar, ao ritmo dos jovens que, nos ombros, carregam os corpos dos irmãos Eduardo e Rafael, assassinados no dia anterior pela polícia. Está chovendo, mas eles insistem em levar os féretros por todo trajeto, desde o bairro popular de Villa Francia até o Cemitério Geral de Santiago. Insistem, talvez, para sentir o peso da morte, para sentir no próprio corpo a perda dos amigos, dos compañeros. Punhos fechados apontam para o céu.

Eduardo e Rafael tinham 20 e 18 anos, respectivamente. Este é um funeral juvenil, de camiseta, tênis e calça jeans. Dois jovens abraçados estão à frente dos caixões enfeitados de cravos vermelhos e martelos. Namorados? Amigos? Irmãos? Ela veste um macacão branco e leva o cabelo preso; com os olhos fechados vai perdida em si. Ao seu lado, ele a ampara pelo ombro e, com a outra mão, ergue bandeira que esvoaça no ar, metade preta, metade vermelha - as cores do MIR. Há bandeiras, flores, faixas e, como em outros funerais, lenços. Porém, os pañuelos, aqui, têm uma dupla função: servem para enxugar lágrimas e, ao mesmo tempo, para ocultar rostos - os rostos dos corpos em levante.

Depois de horas caminhando pelo centro da cidade, chega-se finalmente ao destino final. Os caixões agora avançam de mão em mão por cima das cabeças dos assistentes no estreito corredor 64 do cemitério. Parecem seguir voando por cima da multidão. Parecem féretros em levitação. No campo-santo, ressoam fortes, uma e outra vez, as mesmas palavras gritadas em coro: "Compañeros Eduardo y Rafael Vergara Toledo: !Presente, 
ahora y siempre!”. De pañuelo bem amarrado na região da boca, pendurado nas gavetas mortuárias, um moço observa o instante do enterro. Mas não aguenta: fecha os olhos, fecha o punho esquerdo, estica o braço o máximo que pode, e grita. Grito mascarado que não podemos ouvir. Um grito por Eduardo e Rafael que, um dia antes, andavam mascarados pelas ruas de seu bairro, antes de seus corpos serem perfurados a tiros pela polícia e abandonados no asfalto tingido de vermelho nesse frio do entardecer outonal.

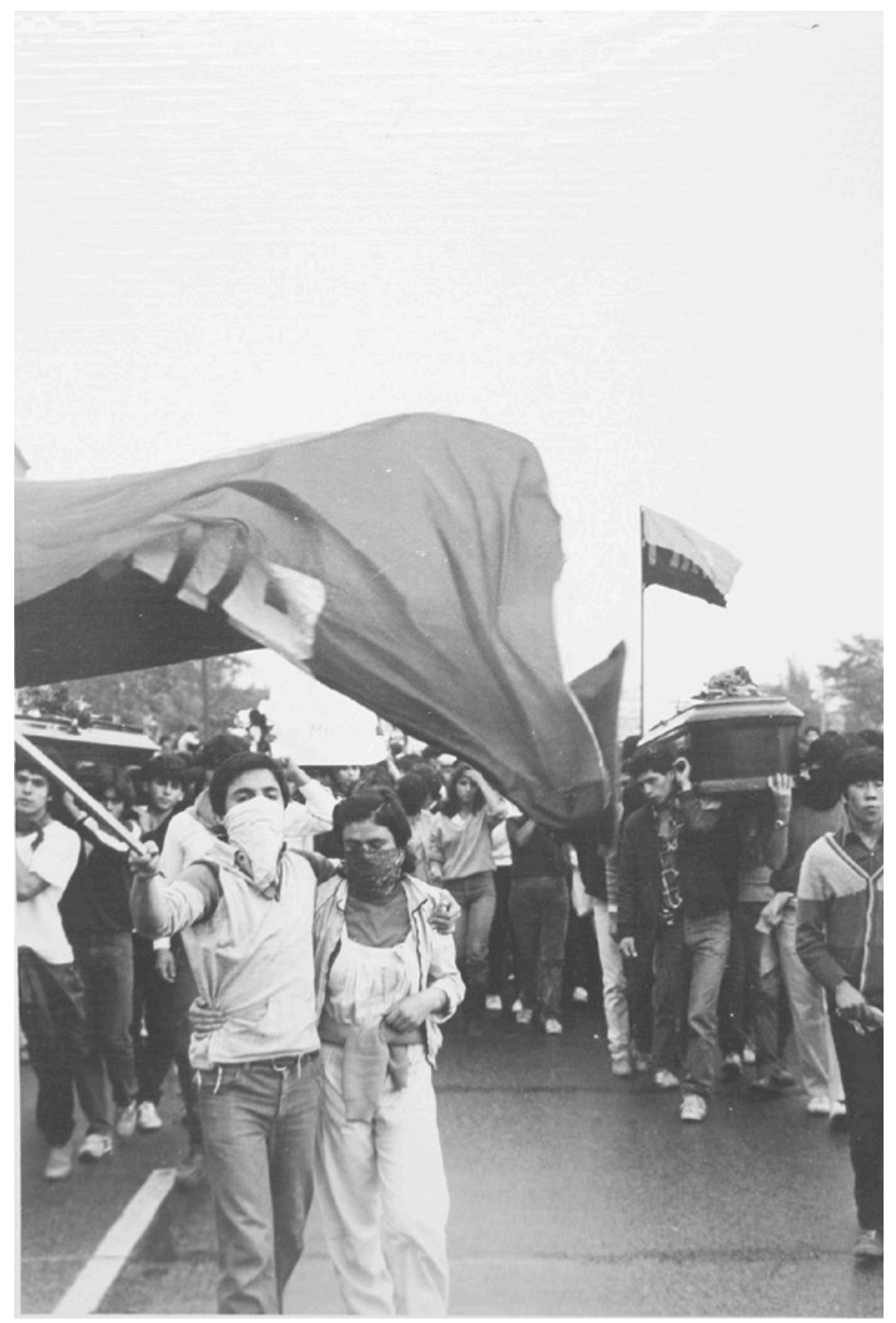

Figura 8: Funeral irmãos

Vergara Toledo (Archivo de la Resistencia Visual, 1985) 


\section{A esquina dos mascarados}

"Justicia para los hermanos Eduardo y Rafael Vergara Toledo". Esta mensagem voava em um papel em 1993, oito anos depois dos funerais dos jovens irmãos e militantes do MIR. A "folha voadora"94, em vez de desaparecer seguindo o destino corriqueiro dos panfletos lançados ao ar, chegou até mim porque foi citado em La Tercera, um dos jornais de maior distribuição no Chile, na edição do dia 30 de março de 1993. A matéria intitulada "Reaparece la violencia" informava detalhadamente os enfrentamentos entre "muchachos enmascarados" e agentes da polícia na esquina das avenidas Macul e Grecia em Santiago, onde se localizavam três campi universitários que, até hoje, continuam ali:

La violencia y la provocación volvieron a pasearse ayer frente al ex Instituto Pedagógico, actual Universidad Metropolitana de Ciencias de la Educación, en la avenida Macul, y a la Facultad de Filosofía de la Universidad de Chile, por avenida Grecia, cuando minoritarios grupos de muchachos enmascarados encendieron neumáticos y se enfrentaron a carabineros, lanzándoles piedras y otros proyectiles. El fuerte de las acciones tuvo lugar cerca de las 13.45, cuando un grupo salió desde el interior de la Facultad de Filosofía para poner neumáticos en el lado sur de la avenida Grecia, lo que fue rapidamente despejado por Carabineros. Se intentaba celebrar así el llamado 'Día del Joven Combatiente', instaurado por sectores extremistas. Primero fueron lanzados trozos de madera encendidos al medio de la calle, con el fin de obstaculizar el tránsito y lograr la presencia de Carabineros, quienes respondieron con bombas lacrimógenas, lo que obligó a los estudiantes a replegarse a los patios universitarios. En la ocasión fueron lanzados panfletos que decían al reverso: "Justicia para los hermanos Eduardo y Rafael Vergara Toledo"; otros, "Justicia para el Chino (Juan Fuentes), asesinado en democracia". También se lanzaron nuevos panfletos, firmados por el llamado Movimiento Juvenil Lautaro, y que decían: "Atracando con la vida y 'en otra'. Somos los locos del poder, viviendo y haciendo victoria de la felicidad. 10 años. Movimiento Juvenil Lautaro (La Tercera, 30/03/1993, itálicos nossos).

94 Expressão emprestada de Georges Didi-Huberman (2017). 
Essa parece ser a primeira vez que o Dia do Jovem Combatente ganhava uma capa em um jornal de circulação nacional95, em tempos quando não se falava ainda de encapuchados fora dos circuitos militantes da esquerda extraparlamentar. As passeatas e atividades para exigir justiça para Eduardo e Rafael Vergara Toledo começaram no ano seguinte aos assassinatos, organizados por parentes e militantes miristas em Villa Francia, na zona sudoeste de Santiago.

Para Pascal Allende, que no fim de 1980 era secretário geral do MIR, as perdas de Eduardo e Rafael, sem desestabilizar a organização, tiveram um grande impacto pelas intensas e breves trajetórias de militância desses jovens, transformando-se em símbolos de luta ativa e não, veja-se bem, de vitimização: essa seria a força moral e política que trouxe seu involuntário sacrifício como legado para as gerações futuras (Insunza; Ortega, 2014, s/p). Rapidamente, os atos de recordação em homenagem aos irmãos Vergara Toledo espalharam-se para diferentes pontos de Santiago, para outros bairros distantes, populares e universitários, como a esquina das avenidas Macul e Grecia. Os shows culturais, musicais e colóquios, incluíam outras formas de recordação: embates violentos entre a polícia de choque e jovens mascarados, assim como Eduardo e Rafael, municiados de pedras e coquetéis Molotov.

Nos anos 1990, a data de recordação dos assassinatos adquiriu importância nos circuitos militantes da esquerda. Paralelamente, passou a ser monitorada pelas polícias e as agências de inteligência do governo de Aylwin. Como discutido no primeiro capítulo, na época quando publicada a capa do jornal, o debate político no Chile discorria acerca da reconciliação nacional e da gestão do chamado "terrorismo de esquerda". Esta última empreitada traduziu-se, entre outras coisas, na sistematização por meio de análises estatísticas das informações da polícia com respeito às atividades de

95 Agradeço a Manuela Badilla, pesquisadora da The New School for Social Research, pela generosidade de compartilhar comigo a capa deste jornal e, mais, por me contar um pouco sobre esse fato. Macul com Grecia, contudo, já aparecia como foco noticioso em setembro de 1991, sendo reportadas barricadas, escaramuças e jovens presos durante a comemoração do 11 de setembro daquele ano (La Tercera, 13 de setembro 1991). 
integrantes (ou, suspeitos de o serem) das organizações tipificadas como terroristas, a saber, o MIR, a FPMR e o Movimiento Juvenil Lautaro (MJL)96.

Em Evaluación de la situación actual terrorista en Chile, relatório publicado em fevereiro de 1993 pelo Conselho Coordenador da Segurança Pública, contabilizavam-se, além de sequestros e ataques à polícia, atos de propaganda que incluíam a construção de "barricadas fugazes" (por certo, a passagem mais poética do informe) e o lançamento de panfletos. Contabilizaram-se como atos terroristas, ainda, outras atividades tradicionais dos movimentos estudantis, como as ocupações de escolas e universidades e a escrita de mensagens políticas em paredes, sob a consideração de que essas eram ações por meio das quais as organizações terroristas recrutavam aderentes no setor estudantil (Consejo Coordinador de Seguridad Pública, 1993, p. 33). Conforme esses critérios de classificação, as barricadas da esquina universitária descritas pelo jornal que aqui analiso, encaixariam perfeitamente no que as agências de inteligência civil chamaram de atos de propaganda terrorista.

Ainda que houve informes sobre a diminuição das atividades da dita extrema esquerda no país, como consequência direta das estratégias de neutralização promovidas pelo governo, o relatório calculava mais de 1.770 atos classificados de terroristas, registrados entre 1990 e 199297. Verificava-se, ademais, um aumento das sabotagens e de atos de propaganda em datas de

96 O Movimiento Juvenil Lautaro, agrupação da qual falei menos no capítulo anterior, incorporou elementos alheios à esquerda revolucionária tradicional: alegria, amor livre e desejo foram conceitos chaves para a organização, que fazia sucesso entre jovens de bairros populares. Além da expropriação de alimentos, o roubo de preservativos para serem redistribuídos em bairros pobres era uma das ações mais lembradas do grupo. Para a inteligência policial, a liderança do Movimiento Juvenil Mapu Lautaro, o sociólogo Guillermo Ossandón, propagava uma lógica dogmática que misturava "prácticas militaristas, posturas mesiánicas y un populismo exacerbado por perturbaciones sicológicas, que recoge las reivindicaciones de la juventud marginal permeable a realizar acciones violentas" (CONSEJO Coordinador de Seguridad Pública, 1993, p. 9). Para mais detalhes sobre a organização, recomendo os excelentes trabalhos do historiador Nicolás Acevedo (2012; 2013).

97 A avaliação positiva do organismo contrasta com a análise para este período do historiador Igor Goicovic (2010), que identificou uma sorte de desorientação geral entre as autoridades do governo de Aylwin com respeito à neutralização dos grupos insurgentes. Sem reparar na real dimensão do fenômeno, seria só em 1992, logo depois do assassinato de Jaime Guzmán, que o governo resolveu em favor de uma estratégia de contra-insurgência mais forte. 
"significación especial”, quer dizer, efemérides ligadas à história das organizações monitoradas pelos aparelhos de inteligência do Estado. Entre elas, o Dia do Jovem Combatente, evento indicado como fator que explicava o aumento desses eventos no mês de março. Por meio da quebra de vidraças e ataques incendiários, atos de baixo poder destrutivo, argumentava-a se no relatório, militantes e simpatizantes da esquerda chilena pretendiam mostrar ao público que ainda estavam operativos em democracia.

Além do Dia do Jovem Combatente, o informe indicava datas sem muita repercussão pública alguma na atualidade, como o Dia do Miliciano Rodriguista, 15 de junho, recordava a Matanza de Corpus Cristi em 1987, quando 12 rodriguistas foram assassinados pela polícia secreta. $\mathrm{O}$ aniversário da fundação da Frente Patriótica Manuel Rodriguez, 14 de dezembro, comemorava a aparição pública da FPMR quando militantes do PC chileno derrubaram torres de energia causando um grande apagão na zona centro do país e, ao vivo, anunciaram em uma afamada estação de rádio acerca do início de um novo período de luta contra a ditadura pinochetista e pela liberdade do Chile liderada pelo FPMR (Reyes, 2016). Curiosamente, acerca da última data que reporta o informe, o Dia do Combatente Lautarista, 5 de maio, não achei informações entre os documentos do MJL. Seria um erro dos analistas?

Atentemos para a composição gráfica da capa do Dia do Jovem Combatente de 1993 (Fig. 9). Com o nariz, a boca e o queixo cobertos com um cachecol, de calça jeans, mochila virada para frente e o estilingue armado para atirar, um jovem de cabelos pretos levita na ponta dos pés, como se dançasse. Embora a estética do moço de pañuelo bem amarrado na esquina de Macul com Grecia nos lembre os mascarados do funeral de Eduardo e Rafael, à esquerda e em segundo plano, à espreita, há uma outra figura um tanto quanto fantasmagórica. De calça jeans e mochila, há um jovem que cobre a sua cabeça inteira com uma camiseta branca, deixando só uma pequena fresta para os olhos mirarem 98 . Foi no decorrer dos anos 1990 que emergiram em Santiago os cabeza de polera, inovação estética e tática nos modos de ocultar a identidade que persiste até hoje. Junto a essas figuras mascaradas, na parte superior da capa e em primeiro plano, na montagem jornalística, vemos a

${ }_{98}^{8}$ Esta imagem me lembra do costume de se fantasiar de fantasma usando um lenço branco cobrindo o corpo todo e deixando só os olhos descobertos por meio de dois buracos. 
contraparte da cena: dois agentes da polícia, de capacetes e cassetete no cinto, próximos de um camburão da polícia de choque. Um deles tenta retirar um pneu que está no meio da rua. Apesar das várias tentativas no decorrer dos últimos trinta anos por parte de especialistas em segurança pública para erradicar tais formas anônimas e efêmeras de rebeldia (persecução criminal, policiamento ostensivo, projetos de lei, infiltração de agentes encobertos), até hoje os mascarados continuam honrando a memória de seus mortos.

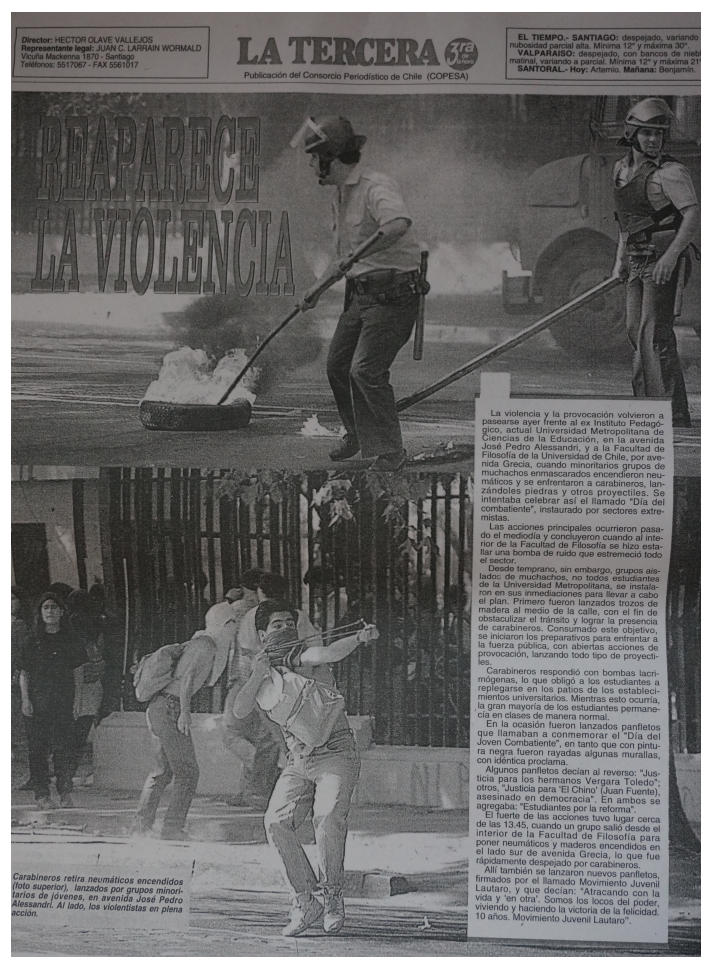

Figura 9: Dia do Jovem Combatente (La Tercera, 1993)

Mortos, Ruas e Mascarados, o segundo capítulo desta tese, explora acerca destas comunhões efémeras, anónimas e disruptivas de corpos que, por meio de barricadas e escaramuças com a polícia, recordam a jovens militantes mortos pela polícia no passado, tanto em ditadura como em democracia. Se evocar é o ato de tornar algo presente pelo exercício da memória e da imaginação, e encarnar é fazer-se carne, materializar-se em algo, incorporar como ente espiritual, eu entendo tais levantes como movimentos de evocação e encarnação de engajamentos políticos à margem das narrativas oficiais e partidárias. "Encapuchados se los llevaron, encapuchados los 
vengaremos" - esta é uma das frases que, talvez, melhor sintetize as cenas que analisaremos nas páginas seguintes.

Na minha leitura, trata-se de exercícios cinéticos de recordação de/por mascarados, memorialização organizadas em contraposição da figura da "vítima" que passou a predominar na política oficial durante a redemocratização chilena. Embates corporais contra a polícia que buscam manter viva as "memórias combativas" daqueles que no passado se insurgiram contra a ditadura e o modelo sócio-económico neoliberal herdado do regime pinochetista, e perpetuado pelos governos posteriores a 1990. Não mais luto, nem lágrimas, mas, no aqui e agora, a revolta. As cenas que revisaremos, deliberadamente, impugnam as normas de participação cívica das democracias liberais ao recusar deliberadamente a máxima da transparência e da não-violência.

Dentre os caminhos possíveis para adensar essas histórias, aposto em uma narrativa que chamo de recursiva. Isso quer dizer que, uma vez e outra, volto à mesma esquina de um bairro universitário na zona sudeste de Santiago, um entrecruzamento de avenidas no qual colidem temporalidades, corpos, lutas e fantasmagorias. Seguirei os rastros deixados por jovens, como Eduardo e Rafael, no instante em que atiravam pedras, lançavam panfletos, fugiam da polícia ou contra-atacavam. Para tanto, utilizo-me de fotografias, panfletos, depoimentos de testemunhas e de participantes, fanzines, desenhos, notas de imprensa e relatórios de instituições de segurança pública. Em termos analíticos, no final deste capítulo, discuto dois conceitos utilizados na academia chilena para entender essas práticas de dissenso: "violência ritual" e "ação direta". Seguindo o trabalho do antropólogo Michael Taussig (2012), meu objetivo é lançar luzes sobre a importância do corpo em tais transgressões, o que me aproxima da noção de "iconoclasmo".

\section{Memórias ativas e combativas}

"Le ganamos la batalla con un lápiz" - com essa frase, a Concertación de Partidos por la Democracia descreveu a bem-sucedida redemocratização 
chilena99. Se destacava a capacidade de negociação que tiveram com as autoridades do regime militar. Sublinhando o espírito "ordeiro" e "civilizado" da nação chilena que, sem tomar as armas, conseguiu dar curso ao Plebicito Nacional de 1988 e as eleições presidenciais de 1989 . Nessa narrativa oficial, as experiências de mulheres e homens que pegaram as armas nos anos 1980 para lutar contra o regime militar de facto, não tinham cabida. A narrativa oficial da transição operou, nesse sentido, pelo não reconhecimento e silenciamento da figura do guerrilheiro. Essa frase, ganhamos com uma canetada, foi repetida pela esquerda parlamentar quase como um mantra e como uma forma de se distanciar o mais rápido possível da resistência e daqueles grupos com os quais havia tido relações de convivência - e até mais do que isso, como, por exemplo, o PC chileno e a FPMR. A mensagem a transmitir pelas lideranças da pós-ditadura era uma: os "violentos" nada tinham a ver como a triunfo da democracia.

Reproduzindo essa matriz que, em 2006, a socialista Michelle Bachelet, em comunicado presidencial oficial advertiu os encapuchados que participavam dos protestos de rua organizados pelo movimento estudantil (a afamada Revolução dos Pingüins), que toda a "força da lei" recairia sobre todos aqueles que fizeram da violência e do anonimato recursos de ação política: "La democracia la ganamos con la cara descubierta, y, debemos continuar con la cara descubierta". Com esse enunciado, em um instante, simplesmente, se esquecia das lutas e dos sacrifícios de homens e mulheres que, decididamente, cobriram seus rostos e pegaram as armas (às vezes, as mais rudimentares) para combater a Pinochet ${ }^{100}$.

\footnotetext{
99 A frase apareceu como manchete no jornal Fortín Mapocho, na edição do dia 8 de outubro de 1988 , sendo posteriormente utilizada para descrever e comemorar o processo transicional chileno.

100 À medida que a distância temporal foi aumentando, cansados do lugar de esquecimento que a Concertación de Partidos por la Democracia havia delimitado para eles, os excombatentes da ditadura de Pinochet passaram a publicar testemunhos nos últimos 10 anos (Arancibia, 2015; Candia, 2014; Rosas, 2013; Tricot, 2015). Assistiu-se, ainda, a um maior interesse público de saber mais sobre a vida daqueles que haviam participado da luta armada. Para a recordação dos $4 \mathrm{O}$ anos do Golpe de Estado sobre Allende, em 2013, por exemplo, foram exibidos, na televisão pública, programas dedicados à história dos grupos guerrilheiros, como o MIR e a FPMR.
} 
Histórias como as de Eduardo e Rafael Vergara Toledo, no entanto, foram recordadas no decorrer dos anos 1990 até hoje. De fato, talvez, é a data de recordação pública não oficial mais persistente do Chile pós-ditatorial. Os nomes desses dois jovens mortos a tiros pela polícia, aparecem em jornais e televisão. Porém, mais do que homenagear as suas vidas, alerta-se a cidadania das desordens que o Dia do Jovem Combatente causa em Santiago: acerca de barricadas e apagões notifica-se por meio de redes sociais. Fala-se, ainda, do Dia do Jovem Delinquente, muitas das vezes ironizando sobre qualquer conteúdo político desse dia de memória. A situação, é outra em bairros periféricos. Pesquisadoras têm explorado o lugar ocupado pelas figuras dos irmãos Vergara Toledo e seu impacto nas memórias e lutas de gerações pós-1990, trabalhos que desde diferentes frentes apontam para as críticas articuladas pelos jovens a figura das "vítimas", tropos que organizou a redemocratização. Essa categoria, que passou a estruturar as políticas institucionais de memorialização instituídas pela Concertación de Partidos por la Democracia, traduziu-se em museus, memoriais e monumentos, aos olhos dos jovens, uma memória estática e que no final de contas, promoveria a desmobilização política.

Gabriela Raposo (2012), por exemplo, explora como por meio de murais, músicas e enfrentamentos com a polícia, a cada 29 de março, busca-se resgatar o projeto de sociedade pelo qual lutavam Eduardo Rafael: uma sociedade revolucionária e anticapitalista. Por sua vez, Tamara Vidaurrázaga (2014) reflete sobre o processo de reconversão dos ex-militantes de esquerda como "heróis" em bairros populares de Santiago. Por último, Manuela Badilla (2017) discute a disputa em torno da ideia de "vítima", olhando para outras formas de construção da memória distintas que acreditam em uma continuidade entre ditadura e democracia: em ambos os períodos, trata-se de um projeto de sociedade neoliberal. Essa é uma das motivações que os leva a se engajarem na construção de memórias locais, como na figura de Eduardo e Rafael, em vez de nacionais (como no caso da Villa Francia), e a assumirem a violência política como recurso legítimo, tendo em vistas as injustiças do sistema atual.

Se os nomes dos irmãos Vergara Toledo evocam algum tipo de reação, seja adversa ou positiva, no entanto, o nome de outros jovens militantes assassinados pela polícia, como o de Juan Fuentes, citado nos panfletos 
lançados ao ar em 29 de março de 1993, em Macul com Grecia, não diz muito. Eu mesma tive que procurar quem fora esse jovem "assassinado em democracia”, como dizia o panfleto. Juan foi um frentista, estudante de filosofia, que faleceu em condições muito parecidas às de Eduardo e Rafael. Junto a Mauricio Cancino, outro jovem militante, eles foram baleados pela polícia, em 14 de dezembro de 1991, quando participavam em atividades de propaganda armada para o aniversário da FPMR. Nem a morte de Juan ou de Mauricio, tampouco o aniversário rodriguista têm consequências públicas: hoje não há atos, nem passeatas ou escaramuças com a polícia.

Nessa medida, cabe se perguntar: por que alguns espectros políticos continuam nos assombrando enquanto outros, simplesmente, vão sumindo com o passar do tempo? Por que alguns mortos que mobilizaram formas de recordação pública, de um momento a outro, deixam de ter tal apelo? No Chile, sem dúvida, as vítimas do terrorismo de Estado são os fantasmas políticos mais recordados, tanto pelo enorme número de mortos e desaparecidos, quanto pela ação dos organismos de familiares e de defesa dos direitos humanos, bem como por políticas de memorialização dos governos da Concertación de Partidos de la Democracia. Contudo, o país os recorda quase como amalgama: "las y los ejecutados y detenidos desaparecidos". Seus rostos e nomes, ano a ano, reaparecem em mapping, projetados nas paredes do colossal Museo de la Memória. Mas como lembrar dos milhares de mortos?

É inexorável: entre geração e geração, há mecanismos de seleção, sedimentação e descarte de memórias. Nos lembramos daqueles que antes de serem executados, por exemplo, foram célebres políticos e artistas, como o cantor Victor Jara. Nos recordamos, também, daqueles que foram assassinados das mais espantosas formas, como o Caso Degollados e o Caso Quemados ${ }^{101}$. Eduardo e Rafael Vergara Toledo, entretanto, não eram nem afamados, nem seus assassinatos foram particularmente cruéis - pelo menos não no contexto da sistematização do horror como ferramenta de

${ }_{101}$ Esse foi o nome dado pela imprensa ao homicídio dos militantes do PC chileno, Santiago Nattino, José Manuel Parada e Manuel Guerrero, em 1985, mesmo dia do funeral de Eduardo e Rafael. Faca no pescoço: os três, de olhos vendados, foram degolados pela polícia; seus corpos, achados em 30 de março de 1985, no mesmo dia do funeral dos irmãos Vergara Toledo, e abandonados em uma estrada da periferia de Santiago. 
neutralização das dissidências políticas. $O$ fato de serem irmãos tampouco era algo excepcional entre os horrores da ditadura pinochetista ${ }^{102}$. Eduardo e Rafael eram apenas dois jovens esquerdistas pobres e periféricos, assassinados a tiros pela polícia - mais dois, entre tantos outros.

\section{A juventude contra o tirano}

O que aconteceu essa tarde de 29 de março de 1985 ? Eduardo e Rafael junto a outros jovens, todos mascarados e alguns deles carregando armas de fogo, estavam a caminho para expropriar uma padaria perto de Villa Francia, bairro onde moravam na zona sudoeste da cidade. Replicar táticas de guerrilha urbana, tal como aquelas propostas por Carlos Marighella no Brasil, naqueles anos, era comum, sobretudo o assalto a lojas de armas, bancos e supermercados para reunir recursos para a luta contra a ditadura'103.

As expropriações eram atividades centrais das milícias populares da FPMR, do MIR e do MJL, que atuavam, principalmente, nas periferias da cidade. Erguer barricadas, lançar panfletos, pixar, assaltar lojas, atacar a polícia, sabotar o sistema elétrico e incendiar eram ações de autodefesa consideradas justas e válidas quando o assunto era contra-atacar o regime de

102 Este fato nos é lembrado pelo belo documentário La ciudad de los fotógrafos (2006), de autoria de Sebastián Moreno. Na filmagem, aparece uma mulher mais idosa de cabelos grisalhos e curtos, Helena Maureira, sentada na pequena sala de sua casa, entre flores e fotografias de seus filhos, Rodolfo Antonio, Sergio Miguel, Segundo Armando e José Manuel, e seu marido Sergio Maureira Lillo, todos executados pela polícia em meados de 1973. Seus corpos apareceram apenas em novembro de 1978, em uma zona rural ao sul de Santiago, junto a outros desaparecidos políticos, também irmãos entre si: Oscar, Carlos e Nelsón Hernández Flores Carlos, acompanhados dos restos mortais de Enrique Astudillo Álvarez e seus filhos Omar e Ramón.

103 Em Manual do Guerrilheiro Urbano, publicado pela primeira vez em 1969, estabelecia-se como objeto essencial da luta a expropriação dos recursos do governo e dos grandes capitalistas, bem como as expropriações menores para a vida e a subsistência dos camaradas (Marighella, 1969, p. 7). 
exceção de Pinochet. Contra-atacar, portanto, era tanto direito como dever do "povo" 104.

Eduardo e Rafael começaram a militar no MIR seguindo os passos de seu irmão mais velho, Pablo105. À diferença deste, que atuava em organizações políticas comunitárias, os jovens uniram-se às milícias. Composta, principalmente, de homens, essa forma de participação, acima de tudo, juvenil, foi compondo uma estética particular que, além da vestimenta de coturnos e calças jeans, incluía outro elemento fundamental: o uso de pañoleta (ou pañolín) para ocultar o rosto inteiro. Exatamente quando apareceram os primeiros militantes mascarados em Santiago é algo que não posso precisar; mas por fotografias, jornais e documentários da época, sabemos que foram nos massivos protestos populares contra Pinochet iniciados em 1983. Sua figura começou a proliferar-se em passeatas, comunicados televisivos clandestinos, sabotagem e confrontos com a polícia e, também, em funerais.

Ainda que os lenços e as balaclavas, prendas mais utilizadas, cumpriam o propósito tático de impedir a identificação policial, com o tempo, esse propósito se converteu em algo mais. As peças começaram a ser fabricadas para a ocasião em tecidos pretos e vermelhos sobre os quais se viam bordadas as iniciais da FPMR e do MIR ${ }^{106}$. A entrega da pañoleta fazia parte do ato de boas-vindas na organização, sem muita cerimônia - às vezes, tocavam o hino dos rodriguistas em um reprodutor de fita cassette. Entre os militantes do

\footnotetext{
104 As milícias do MIR remontam os anos 1960 e as alianças com movimentos campesinos e operários para ações conjuntas de ocupação de terras. Frente à permanente ameaça do despejo, ativistas e pobladores se organizaram para defender os campamentos: antes da ditadura tinham de se defender dos "aparatos represivos del gobierno y del estado burgués", diz o ex-secretário geral do MIR, Andrés Pascal (Arancibia, 2015, p. 142-143).

105 Os Vergara Toledo, inclusive, participavam ativamente das comunidades eclesiais do bairro. Nos anos 1980, as organizações religiosas inspiradas na teologia da libertação eram importantíssimas como espaço de formação política e cuidado mútuo, em tempos de repressão policial e crise econômica.

106 Se bem que há inúmeros trabalhados publicados sobre a história do MIR e da FPMR, sobre as suas formas de organização, divisões internas, táticas e programas; na maior parte, são de historiadores. Mas não há uma análise que explore com maior detenção essas questões estéticas que comento aqui, entendidas como assuntos "menores entre os cientistas sociais.
} 
MJL, as pañoletas eram de cor verde e, em documentários da época107, aparecem dirigentes vestindo balaclavas pretas ou vermelhas, enfeitadas com as iniciais MJL e uma estrela de cinco pontas ${ }^{108}$. Nos protestos de rua, a maior parte continuou a se ocultar com panos improvisados: cachecóis e lenços brancos. Para além da diversidade de formas, cores e texturas (as peças podiam ser de lã, algodão ou poliéster), cobrir o rosto passou a ser um gesto existencial para os jovens rebeldes de esquerda. Transformou-se em forma de ser no protesto. Forma anônima de atuação paradoxal: cobrir o rosto adquiria uma visibilidade própria, forma sensual de apresentação dos corpos rebeldes ${ }^{109}$.

As expropriações, às vezes, tinham por finalidade a obtenção de armas, ações que exigiam um nível importante de coordenação e planejamento. Mas esse não foi o caso do assalto que Eduardo e Rafael pretendiam fazer. Como proposto na reconstrução dos eventos feito pelo historiador Nicolás Diaz (2010) ${ }^{110}$, a ação pretendia arrecadar recursos para a subsistência. Antes de serem assassinados, a polícia havia prendido os jovens em protestos e

107 Refiro-me ao documentário da televisão francesa de 1986 (não há dados do canal de tevê, tampouco nomes do programa). O jornalista acompanha os militantes, todos mascarados com balaclavas, em atividades de expropriação de alimentos em um bairro popular, fabricação de armas de fogo, treinamento de uso de armas, etc. A seriedade e o tom altissonante dos comentários contrastam com a precariedade material e o escasso número de participantes. Registro disponível em: https://bit.ly/2HzEGhB. Acessado em 07/06/2017. Agradeço ao historiador Nicolás Acevedo por me indicar o material.

108 Essas últimas prendas eram muito parecidas àquelas utilizadas pelos militantes da Movimiento Revolucionario Tupac Amaru (MRTA) no Peru.

109 Sob o princípio da compartimentalização da informação, muitas vezes, entre os próprios milicianos, desconhecia-se quem mais iria participar de um ato para evitar delações. Assim, Ana, irmã caçula dos Vergara Toledo, que com 14 anos já militava no MIR, anos depois, iria recordar que não era raro chegar a atividades do movimento e reconhecer Eduardo e Rafael mascarados (Diaz, 2010, p. 95).

110 O trabalho de Nicolás Díaz é um dos mais completos publicados até agora sobre o caso dos Vergara Toledo. O historiador realizou entrevistas com os pais e outros familiares dos falecidos, além de uma pesquisa documental de bastante fôlego. Aliás, esse foi o seu TCC, escrito para uma graduação em história na Universidad de Chile em 2009, sob a orientação do professor Gabriel Salazar. 
funerais ${ }^{111}$. A situação de perseguição agravou-se quando a casa deles foi invadida, em 18 março de 1984. Ana Luisa Toledo e Manuel Vergara, ambos atuantes na Vicaría da Solidaridade, uma das mais importantes organizações de defesa dos direitos humanos da época, denunciaram irregularidades: falta de autorização judicial, destruição e roubo de vários pertences, entre eles livros que, aos olhos da polícia, contavam como material subversivo.

Pelo risco certo que corriam, Eduardo e Rafael iniciaram uma vida de clandestinidade pobre, sem ajuda econômica do partido (Diaz, 2010). Tão pobre que viviam escondidos no próprio bairro para usufruir da solidariedade dos vizinhos. É nesse contexto que os dois teriam decidido assaltar a padaria, o que não chegou a acontecer, pois a polícia os interceptou antes que eles pudessem sequer chegar ao estabelecimento.

Há uma segunda versão sobre o motivo da expropriação. Não teria sido um ato de supervivência econômica, mas uma ação direta para homenagear outro jovem mirista morto um ano antes, Mauricio Maigret Becerra. Com 18 anos, conforme relato da Comissão da Verdade e da Reconciliação, em 29 de março de 1984, Mauricio recebeu dois disparos de fuzil da polícia enquanto vigiava o ataque que outros militantes acometiam contra a Subcomisaria Teniente Merino na comuna de Pudahuel, zona sul de Santiago. Nos anos 1980 , ataques a recintos policiais nas periferias eram frequentes, nos quais eram usados dinamite, coquetéis Molotov, pedras, disparos e granadas lançadas por foguete em bairros populares (Silva, 2014). O mesmo ocorria com furgões e viaturas, assediados constantemente por milicianos ${ }^{112}$.

111 Tal como aconteceu com Eduardo no funeral do dirigente sindical e militante do Partido Radical, Tucapel Jiménez, assassinado por agentes da inteligência militar em 1982.

112 Héctor Maturana, rodriguista que participou em 1986 do espetacular atentado contra Pinochet, condenado à expatriação perpétua pelo governo de Aylwin, lembrou-se da sua primeira experiência com 14 anos nas milícias: "Fuimos directo, una bomba en la comisaría, ese mismo día me pasan una pistola, [abaixa a voz] una 38, pum, y ese mismo día hicimos contención a uma bomba que se puso en Independencia, así fue la historia. A ellos les pareció que estuve bien, el hombre tiene sus nervios. Una cosa súper informal. Nunca supe los nombres de ellos pero era como si los hubiera conocido de toda la vida. Había una señora, una mujer, entonces me sentía en confianza. Se juntaba en restaurantes, tampoco tan mística la cosa, y se tomaban unas copas y listo. Se planificaba de esa forma" (Extrañosiento, documentário de Manuel Ahumada, 2014). 
Para além dos motivos da expropriação da padaria em Villa Francia, a tese da repressão política defendida pela família Vergara Toledo foi confirmada pelo veredito judicial, 25 anos depois dos crimes. Tratou-se mais do que uma cacería policial'13.

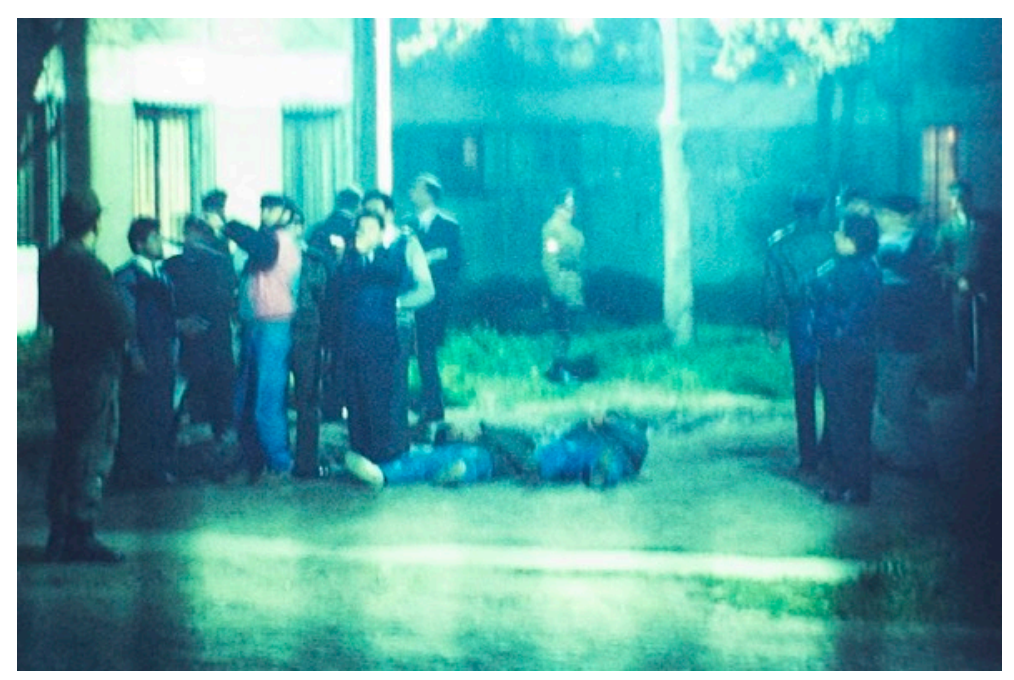

Figura 10: Recriação policial (TVN, 1985)

Os jornais da época, por sua vez, informaram de dois "criminosos subversivos" a mais abatidos em enfrentamento que quase matou a um policial. Quase, porque recebeu imediata atenção médica, não como Rafael quem, imobilizado no asfalto em estado paraplégico com suas costas perfuradas a tiros, foi carregado pelos policiais até um camburão blindado onde receberia um último disparo fulminante, dessa vez, na cabeça ${ }^{114}$. Mas isso foi negado pelos policiais que, replicando as práticas de falsificação forense corriqueiras no período, regressaram o cadáver de Rafael ao asfalto e posto e o colocaram ao lado do corpo de Eduardo. Ficções como evidências:

\footnotetext{
${ }_{113}$ "Al verse sorprendidos, huyen hacia los pasajes interiores de la población siendo perseguidos por los carabineros en cuestión, los que ya habían reconocido a los hermanos Vergara Toledo como unos de los sujetos que huían, procediéndose a la persecución de los mismos [...] no cabe sino concluir que lo que comenzó como una persecución para reprimir un asalto a una panadería se convirtió en una cacería de quienes eran sus partícipes, al darse cuenta los agentes policiales que se trataba de los hermanos Vergara Toledo, reconocidos partícipes de muchas actividades contrarias al gobierno" (CORTE SUPREMA, Recurso 7089/2009, Resolución 27667, 4 de agosto de 2010).

114 Em 2017, foi condenado à prisão o policial Axel Ambler por ser autor do disparo na cabeça de Rafael Vergara Toledo.
} 
movimentação de materiais para confirmar a versão policial, a saber, os subversivos reduzidos em fuga e em confronto, em confronto ${ }^{115}$. A montagem cadavérica seria replicada anos depois na investigação policial, como mostra uma fotografia onde vemos dois corpos, de tênis e calça jeans, deitados no chão, imitando Eduardo e Rafael. Corpos colocados onde, até hoje, a cada 29 de março, chegam outros jovens mascarados para recordar, em levante, aos filhos de María Luisa e Manuel.

\section{If you hold a stone ${ }^{116}$}

São doze quilômetros de distância entre a Villa Francia e a esquina de Macul com Grecia. Eduardo viajava todos os dias do bairro para o Instituto Pedagógico da Universidade do Chile, onde estudava para ser professor de história e geografia. Embora a universidade seja até hoje conhecida pelo seu diminutivo, El Peda (ou, ainda, El Piedragógico, dada a recorrência dos embates entre mascarados e a polícia), seu nome oficial é outro: Universidade Metropolitana das Ciências da Educação (UMCE). A instituição foi assim rebatizada pelo Ministério de Educação do regime pinochetista e foi desvinculada da Universidade do Chile como um castigo à comunidade educativa "ideologizada", que teve a ousadia de se mobilizar contra a ditadura.

Na década de 1960, o endereço Macul, número 744, reunia a Faculdade de Filosofia e Educação e o mencionado Instituto Pedagógico da Universidade do Chile. Os programas de graduação em jornalismo, sociologia, letras, história e antropologia tinham lugar neste profícuo espaço intelectual e político. Da mesma forma que em outras regiões latino-americanas, os diversos partidos e movimentos de esquerda chilenos, entre eles, o MIR,

\footnotetext{
115 Allen Feldman (2015) trata das falsificações de evidências no caso de Gul Mudin, jovem de 15 anos assassinado em Afeganistão por militares estadunidenses. Na análise, o antropólogo discute a mutilação do corpo e as fotografias pós-mortem que foram tiradas pelos militares para justificar a sua versão: "the political identity of the victims before they were killed is rendered inmaterial, and why ex post facto forensic falsification becomes a mechanical reflex that merely extends a preinstalled jurisdictional right to forge the substrates that will carry dominion in their counterfeited bodies" (Feldman, 2015, p.81).

116 Nome de música de Caetano Veloso inspirado na artista Lygia Clark, do disco Caetano Veloso (1971).
} 
discutiam a possibilidade do socialismo e da revolução no país, à luz das experiências locais de lutas operárias e camponesas, e também dos acontecimentos internacionais que impactaram o imaginário e as práxis das esquerdas, sendo paradigmáticas nesse sentido a Revolução Cubana (1959) e o Maio de 1968. Era nesses termos retóricos, de revolução e socialismo, que federações, centros estudantis e organizações partidárias e não partidárias discutiam o futuro do país.

Em 1979, com a vitória presidencial da Unidade Popular, projeto encabeçado pelo socialista Salvador Allende, a via eleitoral para o socialismo deixava de ser uma quimera' ${ }^{117}$. Intelectuais do mundo todo chegaram ao país para testemunhar a vitória do projeto de Allende, entre eles, o escritor Julio Cortázar, que discursou para mais de 6oo estudantes no campus de Macul118.

No primeiro ano do regime civil-militar, professores da Universidade do Chile foram exonerados; carreiras como sociologia e antropologia foram acusadas de infestação ideológica e fechadas. Centenas de alunos desapareceram. Os cargos de direção universitária passaram a ser indicados pela Junta Militar, sendo muitas das novas autoridades ex-integrantes das Forças Armadas com suspeitas trajetórias acadêmicas. As mudanças afetaram todas as universidades públicas do país. Paralelamente à repressão e à tortura, o governo considerou fundamental reestruturar as políticas educacionais para expurgar, desse modo, o câncer marxista do corpo social. Os jovens deveriam ser reencaminhados para os valores do patriotismo e da responsabilidade e

117 Salvador Allende foi candidato nas eleições presidenciais de 1952, 1958 e 1964, antes de ganhar em 1970. Sobre o significado da vitória de Allende na esquerda global, ver a segunda parte do documentário O fundo do ar é vermelho, do diretor francês Chris Marker (1977).

${ }_{118}$ O escritor chegou ao Chile para participar da posse presidencial de Allende, em 3 de novembro de 1970. Em carta a seu amigo Roberto Fernández Retamar, escrita em 29 de novembro, expressava-se sobre a visita: "Sabrás quizá que me fui a Chile para decirle a Allende y a su gente cuánto me gustaba lo que está ocurriendo en ese país”. Posteriormente ao golpe de estado de 1973, Cortázar comprometeu-se na denúncia internacional da violação dos direitos humanos no país. Outra visita importante na época foi a de Angela Davis, em 1972, na Universidade Técnica do Estado, onde clamou, aos estudantes e professores, pela defesa do projeto de Unidade Popular, enquanto a direita chilena e o governo dos Estados Unidos explicitamente atacavam a legitimidade do governo de Allende. Antes disso, em 1971, Fidel Castro permaneceu três semana no Chile em uma visita de apoio ao projeto allendista, visita que incluiu um discurso na Universidade de Concepción, no sul do país. 
afastados da politiquería que havia se apoderado dos centros educacionais nas décadas anteriores.

Com os partidos de esquerda banidos, qualquer atividade política passou a ser proibida tanto nas escolas como nas universidades. Aos olhos dos militares, aos estudantes só thes cabia uma coisa: estudar. Nesse contexto, foi frequente o monitoramento das atividades de resistência por meio da infiltração nos espaços universitários e secundários - e essa presença de agentes da polícia secreta era de público conhecimento nos campi ${ }^{119}$.

Eduardo Vergara Toledo complementava sua militância no bairro com a participação ativa na política universitária, sobretudo na Unión Nacional de Estudiantes Democráticos (UNED). Quando foi aprovada a reforma da educação, em 1981, o Instituto Pedagógico foi, abruptamente, desvinculado da Universidade do Chilei2o. Vários autores concordam que a decisão do Ministério do Interior foi um castigo à comunidade por causa das mobilizações estudantis (García, 2015; Tamayo; 2004; Toro, 2015). A separação, além de importantes cortes orçamentários, tinha um efeito desmoralizador: aos estudantes baderneiros se lhes quitava o orgulho de pertencer a mais prestigiada e politizada universidade do país, decisão que foi celebrada pela imprensa simpática ao regime militar - vale dizer, eram tempos em que o proselitismo de jornais e colunas de opinião tendiam ao elogio do livre mercado e dos benefícios da privatização da educação, da saúde e do sistema de previdência social.

Em 1983, Eduardo foi expulso da universidade acusado de militância subversiva. O mesmo aconteceu com Rafael, que, com 15 anos, é acusado de

119 Em 1980, como forma de contestar essa presença indesejada, os estudantes colaram cartazes com as fotografias dos agentes à paisana, junto com a frase: "Se busca" BUSCA (Toro, 2015). A perseguição política de estudantes foi uma prática corriqueira e gerida pelo próprio Ministério de Educação, afetando inclusive as escolas secundárias. Sobre essas práticas, ver os testemunhos de ex-lideranças estudantis em Los Niños de la Rebelión, livro do jornalista Mauricio Weibel (2017).

120 A Ley General de Universidades promulgada em 1981, sob os princípios do livre mercado, deu início a privatização da educação superior, exigindo o pagamento de parte dos próprios estudantes, criando para tal um sistema de créditos, assim como a eclosão de estabelecimentos universitários privados, somando, ainda, a desestruturação da rede de universidades públicas previamente existentes a nível nacional. 
terrorista e forçado a se retirar do Liceo Aplicación, tradicional escola secundária pública que teve protagonismo nas mobilizações contra o ditador organizadas na época. Em 1985, ocorreram grandes protestos no Instituto Pedagógico: a comunidade estudantil exigia sua reincorporação na Universidade do Chile. O número de participantes cresceu em razão das mobilizações populares e intersetoriais que se multiplicavam em Santiago exigindo o fim da ditadura pinochetista. A repressão não tardou: mais de 600 alunos e 60 professores foram presos pela polícia para, então, serem inspecionados por agentes secretos que, com seus rostos cobertos, iam identificando os manifestantes mais politizados (Barría, 2012).

Aos olhos de quem defendia o governo pinochetista, os estudantes que participavam dos protestos de rua eram como homens das cavernas anacrônicos, retrógrados, obsoletos. Pelo menos era assim que apareciam no panfleto lançado para alertar os jovens dos perigos do Homo Piedricus, espécime que pululava nas universidades, de rosto coberto, atuando como incitador de ocupações, construtor de barricadas e exímio atirador de pedras. No panfleto, sem data específica, encontrado entre 1983 e 1989, o desenho de um homem das cavernas com o punho esquerdo levantado vai acompanhado da advertência: "No geral, cobrem seus rostos porque do pouco que entendem, intuem que é um desprestígio o que eles fazem. Eles sabem algumas consignas de memória e parecem ser normais. Se cuide: podem te alastrar ou intimidar e é só um tonto". Essa campanha pró-regime, ao meu ver, antecede os formatos que, hoje, na Internet, misturam imagens, piadas e asseverações infundadas para serem espalhadas, de modo a ridiculizar as lutas sociais, entre elas as de estudantes, seja no Chile, seja no Brasil. 


\section{Homo Piedricus}

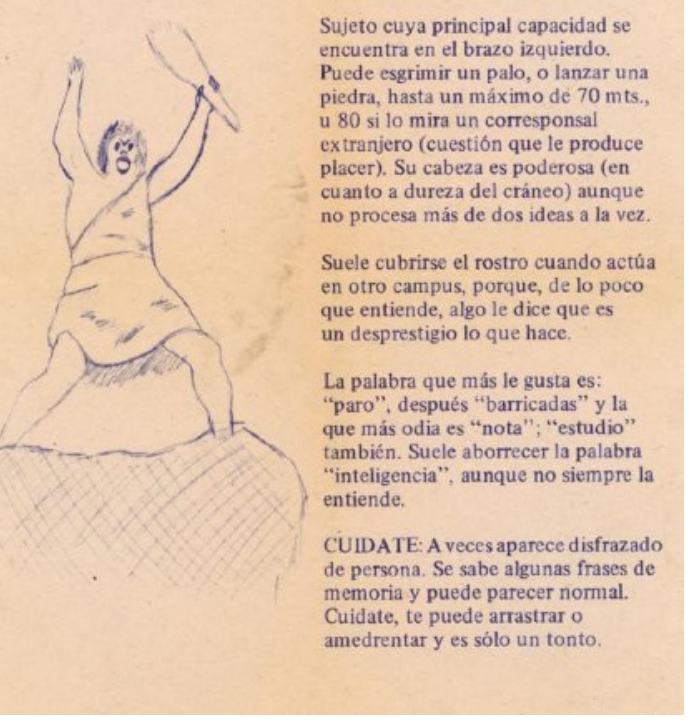

Figura 11:

Panfleto pro-Pinochet (Karque, 2003)

O panfleto, exercício anônimo de humor pró-ditatorial, descreve os mascarados como trogloditas. Naquele tempo, o termo encapuchado, hoje de uso corriqueiro, só circulava na boca de militantes de esquerda e praticantes de lutas callejeras. Exercício de humor análogo seria replicado décadas depois, mas já não de forma anônima. Em Diccionario de la política chilena, os influentes cientistas políticos Alfredo Joignant, Francisco Díaz e Patricio Navia (2012) ${ }^{121}$, definiam conceitos e expressões corriqueiras da política nacional de modo pretensamente sarcástico e irônico. Com esse espirito, definiam encapuchado como:

Sujeto mas bien malandra, cargado de malas intenciones, arropado con pañuelos, turbantes, bufandas, pasamontañas cuya función es cubrir por completo el rostro y eventualmente la cabeza, a usanza de una capucha. El encapuchado adquirió notoriedad (aunque ya existía en Chile en calidad de delincuente, de $\rightarrow$ lumpen o de terrorista

121 Joignant é acadêmico da Universidade Diego Portales e diretor do maior cluster de pesquisa sobre conflito no Chile, o Center for Social Conflict and Cohesion Studies (COES). Díaz, por sua vez, é militante socialista, foi assessor de Michelle Bachelet e, hoje, é pesquisador do CIEPLAN. Navia é influente colunista em importantes jornais nacionais e acadêmico da Universidade Diego Portales. 
durante la $\rightarrow$ dictadura militar) en el contexto del movimiento estudiantil de 2011, en el que se le veía destruyendo locales comerciales, luminarias y semáforos, pero nunca reivindicando una mejor educación. Existen serias dudas sobre quiénes son realmente: para los momios $\rightarrow$ se trataría de estudiantes $\rightarrow$ ultras poco interesados en resolver el conflicto, y para otros se estaría en presencia de lumpen, delincuentes y violentistas. De cualquier forma, el encapuchados aspira a ocultar su identidad, lo que supone falta de convicciones democráticas y cobardía. A diferencia de los encapuchados que protestaban en la dictadura, amparándose en el anonimato para protegerse de la represión estatal en un país donde no existía el Estado de derecho, aquellos que lo hacen en democracia se amparan ene el anonimato pese a la existencia de un Estado de derecho donde las marchas y las manifestaciones son legales y legítimas. Ver además $\rightarrow$ talibán $\mathrm{y} \rightarrow$ chiita (Joignant et al., 2012, s/ p, grifos meus).

No cerne dessa definição pretensamente jocosa, reitera-se a comparação ética-temporal corriqueira no debate político nacional chileno acerca dos encapuchados como figuras rebeldes - talvez aceitáveis na ditadura, mas absolutamente abjetas no presente democrático. No limite, para esses autores, trata-se de um ocultamento como traço de covardia por parte daqueles que se aproximariam mais do terrorismo (referenciando o leitor, de forma chistosa, aos termos "talibã" e "xiita”) que do movimento estudantil.

\section{Epístolas carcerárias}

Em setembro de 1997, um preso político recebeu uma carta remetida não por um cavernícola, mas por um primata ${ }^{122}$. Primata foi o apelido escolhido por um encapuchado para assinar a mensagem onde narrava, a um "revolucionário encarcerado", as atividades de comemoração do recém passado 11 de setembro, entre as quais estavam incluídas notícias das barricadas em Macul com Grecia. A missiva fez-se pública por decisão do destinatário, sob o entendimento de que o conteúdo era de interesse para todos aqueles "ANTI-SISTEMICOS-LIBERTARIOS-REVOLUCIONARIOSANTICAPITALISTAS" (grifos do original) que lutavam contra a "democracia de papel”. A carta circulou no boletim Alerta, editado pelo coletivo Kamina Libre, composto por um pequeno grupo de presos políticos ex-militantes da

\footnotetext{
${ }^{122}$ Agradeço ao historiador Nicolás Acevedo por compartilhar este documento comigo.
} 
Juventud Mapu Lautaro (MJL) encarcerado na Cárcel de Alta Seguridad $(\mathrm{CAS})^{123}$.

Conforme informações do boletim Alerta, mais de 160 homens e mulheres militantes permaneciam encarcerados em 1997 pelo perigo que representavam suas ideias e ações, em especial as expropriações a bancos, os ataques seletivos a policiais e partícipes do regime pinochetista, as ofensivas incendiárias a recintos policiais, entre outras práticas. Como exemplo, podemos citar Rodolfo Retamales e Pablo Morales, integrantes do coletivo Kamina Libre, condenados a 40 anos de prisão por serem cúmplices do homicídio de três policiais em emboscada perpetrada pelo MJL em 10 de setembro de $1992^{124}$.

Kamina Libre buscava a libertação dos presos políticos por meio de uma linguagem que incorporava elementos do anarquismo e do punk, remarcando em seus discursos e imagens uma lógica anti-partidária, autônoma e contracultural (Solar, 2007). Tal direcionamento, na contramão das orgânicas marxista-leninistas, possibilitou o estabelecimento de relações entre o pequeno coletivo e grupos de fora da prisão. A luta anticarcerária, nessa época, mesmo sendo uma luta minoritária na sociedade chilena,

${ }_{123}$ Trata-se de um grupo minoritário, mas, como iremos ver no capítulo seguinte, ocupa um lugar fundamental nas hipóteses da polícia chilena no século XXI na persecução criminal do que chamam de "violência antissistema". Acerca do uso do k, em vez da letra c, é um dos traços característicos dos movimentos anarquistas que, naqueles anos, emergiam em Santiago, seguindo as tendências vistas na Europa. A ideia era subverter inclusive as regras ortográficas entre aderente de movimentos de ocupação de moradias. Hoje, a transgressão já foi regulamentada pela Real Academia de la Lengua Española, que inclui a palavra "okupa” em seus verbetes. Acerca dessa escolha, o próprio Kamina Libre discorreu: "La letra K es una consonante velar, explosiva y sorda: es genuina del idioma mapuche. Suena muy fuerte guturalmente. La utilización de esta letra, entre otras cosas es una abierta manifestación 'Kontrakultural'” (Solar, 2007, p. 56).

124 Os policiais mortos, César Arriagada, Claudio Hormazábal e Patricio Arriaza, que ganharam a condição de mártires da instituição, desempenhavam papeis na equipe de segurança da moradia do Intendente de Santiago, o democrata cristão Luis Pareto. O combate dos suspeitos "extremistas" e "terroristas" foi transmitido ao vivo pela televisão. As imagens merecem ser vistas: centenas de policiais, a maioria à paisana, correndo armados e com um cinto vermelho no braço pelas ruas do bairro nobre onde foi arranjada a emboscada. Imagens disponíveis em: https://bit.ly/2ZBtJWJ. Acessado em: 04/05/2019. 
suscitava a convergência de uma miríade de coletivos libertários na capital (Quiroga, 2014).

Como rememorou o historiador Nicolás Acevedo, que participou dos movimentos pelos presos políticos na década de 1990, no início da democracia, era muito difícil que a população solidarizasse com os presos "extremistas" que não queriam entender que a ditadura já tinha acabado. No entanto, para os grupos que defendiam a violência política que continuaram ativos, ainda que em termos formais a ditadura tivesse acabado, o que se vivia era uma "fraude". Que democracia era essa que mantinha o ditador no poder? $\mathrm{Na}$ avaliação dos grupos de esquerda que continuaram perpetrando sabotagens e ataques seletivos, barricadas e apagões como repertórios de luta anticapitalista, a Concertación de Partidos por la Democracia, em nome do estado de direito e escondido no símbolo do arco-íris, tinha aperfeiçoado as estratégias de neutralização de toda organização popular que colocasse em risco a continuidade do legado econômico-social da ditadura: o neoliberalismo. "Pinochet, Aylwin, Frei, la misma mierda!! - concluía o boletim Alerta de 1997 ao analisar os tratamentos dos presos políticos e as políticas de isolamento ensaiados pelo governo do democrata cristão Eduardo Frei (1994-1997).

Confeccionado com recortes de jornais, desenhos, textos escritos a caneta e outros à máquina, os textos do boletim anticarcerário informavam acerca das greves de fome e outras ações coordenadas entre "revolucionários cativos" para exigir o respeito aos direitos dos presos que, na maioria das vezes, lhes eram negados por terem sido condenados pela lei de Segurança do Interior do Estado. Experiências de organizações prisionais diversas reunidas sob o conceito de cárcel combativa, disposição ética política que colocava no centro da vida prisional a dignidade, tanto para a eles como para seus parentes e amigos. A questão das revistas vexatórias, a proibição das visitas íntimas e a imposição de locutórios ${ }^{125}$ foram prerrogativas recusadas de forma coletiva pelos presos por meio de greves.

125 Salas que separavam por vidraças os presos das visitas, sendo a comunicação apenas via interfone - estruturas existentes só nessa unidade penal. Dada a recusa dos presos, finalmente, os locutórios foram desmantelados. Essas medidas arquitetônicas, como visto no capítulo primeiro, visavam a desarticulação política dos presos e o esfriamento de sua atitude de combate permanente no cotidiano prisional. 
Além disso, promovia-se uma forma de ser no cotidiano prisional de permanente confronto com a máquina penal. Os corpos militantes, espaço último de resistência, deviam recusar o disciplinamento imposto pela prisão: em vez de olhar para o chão, olhar nos olhos dos guardas, nunca se ajoelhar ou estender-se no chão, não colocar os braços para trás, nas costas, entre outras disposições corporais. Ademais, buscava-se dificultar o policiamento das celas. "Nos podrán quitar la libertad pero no la dignidad" - esta frase explicava o sentido dessa forma de viver o encarceramento. Nesse cenário, a fuga era a máxima expressão de rebeldia revolucionária. Nos anos 1990, não foram raras as fugas planejadas de militantes, sendo a mais recordada a acontecida em 30 de dezembro de 1996, quando quatro militantes da FPMR foram resgatados por helicóptero da Cárcel de Alta Seguridad (CAS), operação conhecida como Vuelo de Justicia ${ }^{126}$.

Voltando à carta do encapuchado, as últimas comemorações do 11 de setembro de 1997 foram relatadas nos seguintes termos:

Qué mejor manera de saludarlo contándole que el "11" estuvo BACAN: que los que estamos aquí afuera seguimos en la lucha, que el sistema no nos ha doblado ni el brazo, ni la mente: que no hemos dado ni un paso atrás y nuestro norte sigue siendo un Chile con justicia e igualdad. Que nos paramos sin miedo a un murallón aperado con lumas y escudos, balas y lacrimógenas; que cada vez que podemos, nos encapuchamos y no para esconder nuestros rostros, sino para que vean nuestros ojos, los ojos de nuestros hermanos, de los que por cualquier motivo no puede seguir haciéndole frente a este sistema de cuerpo presente; que nos encapuchamos para que no sepan quien los mira detrás del pasamontañas, para que no puedan distinguir en la silueta de ese rosto rebosante de odio y valor, ávidos de justicia y venganza, para que se caguen de miedo y vean en persona, frente a ellos sin un ápice de temor y armados con la razón, a nuestros queridos hermanos. Para que vean a PALITO y a PUMPUM, a PEDRO y a FEÑA, a ALEX y FABIAN, a ARIEL, al PAPI y al MONO SOSA... Y a tantos otros... Nos encapuchamos y les hacemos hervir el culo, los bototos, los escudos con nuestro fuego de libertad. Para que usted hermanito y todos los demás socios que se

126 Entre os “combatentes recuperados", estava Mauricio Hernández Norambuena (o Comandante Raúl), que hoje cumpre pena de privação de liberdade no Brasil pelo sequestro de Washigton Olivetto em 2001. Em 30 de janeiro de 1990, antes de Patricio Aylwin assumir a presidência, 49 presos políticos fugiram da Penitenciária Pública de Santiago através de um túnel escavado durante 18 meses, por 24 militantes da FPMR, marco da história de fugas e resistências prisionais no país. 
encuentran en "cana”, estén aquí, presentes (caixas altas do original, os outros grifos são meus).

Invocação e encarnação. As lutas mascaradas transformam os ausentes - desaparecidos, mortos em combate e lutadores presos - em presenças reais. O corpo encapuchado emerge entre a ausência e a presença: usam-se panos e prendas para ocultar o rosto, mas nesse instante que se nega a identidadeindivíduo abrolha uma experiência comum, efêmera e particular, onde os mascarados acoplam-se uns aos outros. Processo mimético que ocorre mediante uma reprodução seriada de corpos mascarados de modos mais ou menos idênticos. Um cúmulo de mascarados-assim-como-eu (Riisgaard; Thomassen, 2016). Há, nesse sentido, o instante do ocultamento, de sair às ruas a recordar, mascarado, todos os mascarados ausentes, momento de comunhão e encarnação: os meus olhos são os olhos dos irmãos ausentes. Meu corpo mascarado, agora, está de frente para o inimigo, que matou ou capturou outros jovens anticapitalistas, como eu. Mascarar-se não é se esconder: é se multiplicar. "Para nosotros cada capucha es un espejo, un rostro querido, un hermano caído que se levanta en otros. Hermoso lenguaje este, donde todos somos uno y viceversa. Un abrazo grande para ti y através de ti a todos los sin rostro" - disse o "revolucionário cativo" ao primata anônimo que escreveu a carta.

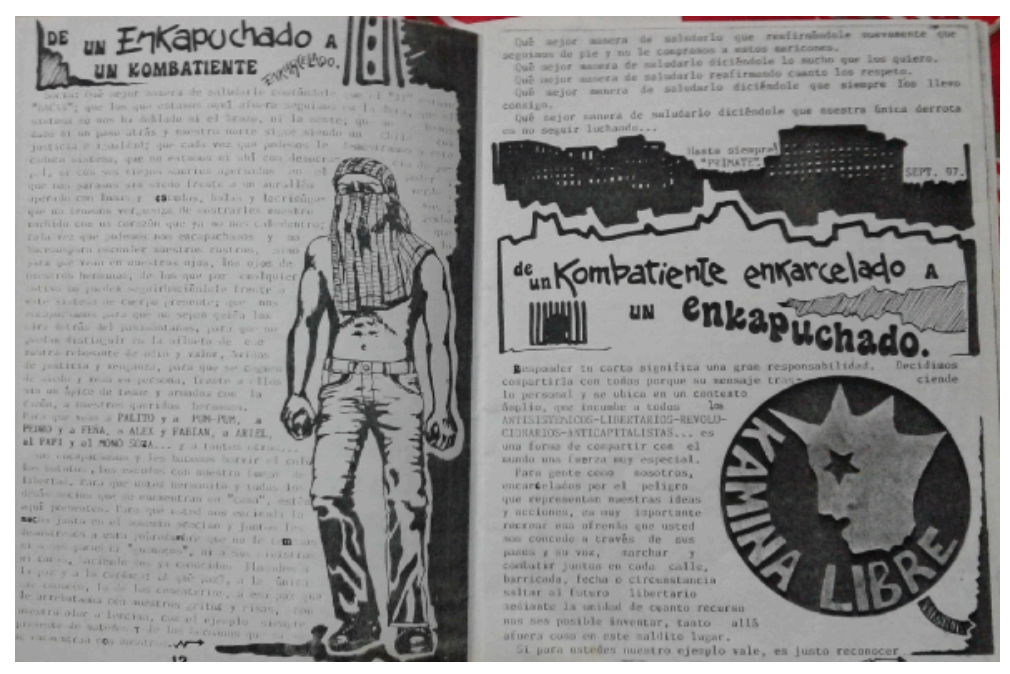

Figura 12 : Fanzine Alerta (arquivo Nicolás Acevedo, 1993) 
No relato, ainda, traça-se uma genealogia histórico-política. Recitam-se nomes e apelidos de jovens que são apenas conhecidos em alguns circuitos militantes. Mencionados na carta como se fossem muito próximos, são recordados com ternura, apesar do tom bélico do material. Em duas linhas, os jovens invocados sintetizam a história da neutralização dos não-reconciliados: Pedro Ortiz, Mauricio Gómez (Pum Pum) e José Martínez (Palito), rodriguistas baleados em fuga da Penitenciária Pública em 10 de outubro de 1992 ${ }^{127}$. Andrés Soto (Papi) militante do MJL, baleado em 10 de setembro de 1992 durante atentado contra a equipe policial de segurança do Intendente de Santiago, Luis Pareto. Fabián López e Alex Múñoz, rodriguistas baleados em janeiro de 1992 depois de libertar, ilesa, a família sequestrada em Ñuñoa. Marco Antonioletti, estudante secundário lautarista baleado em 14 de dezembro de 1990, que fugitivo, foi entregue à polícia pelo pai da família que o escondia em operativo onde participaram centenas de policiais ${ }^{128}$. Alejandro Sosa (Mono), lautarista morto a tiros em outubro de 1993 durante recuperação bancária junto a Yuri Uribe e Raúl González'29.

Linhagens são tudo, menos estática. Aqueles mortos citados em cartas dos anos 1990, deixam de aparecer nas cartas de presos políticos das décadas seguintes. Novos mortos vão sendo incorporados, e outros, com o passar do tempo, começam a ser esquecidos. Mas a moral da história é mais ou menos a mesma: hoje, como antes - e como provavelmente seguirá ocorrendo no futuro, enquanto não houver justiça -, jovens em levante contra a ordem em vigor seguem sendo mortos pela polícia. Narrações que amarram vidas, símbolos, formas de luta, lugares e histórias tecem um passado comum. A história do fanzine da figura 11 foi narrada por um encapuchado que os editores do boletim Alerta decidiram representar por meio de um desenho hiper-masculinizado, jovem forte, que cobre seu rosto com uma camiseta, tal

127 Acerca das fugas de presos políticos nos primeiros anos da transição chilena, ver: Palma (2019), Saavedra e Proenza (2015) e Zapata (2005).

128 Ver o documentário "Antonioletti” de Escuela de Cine de Chile (2O10), onde aparece o filho, sua companheira e atos de memória em sua homenagem. Disponível em: https:// vimeo.com/191685974. Acessado em 04/03/2019.

129 Episódios, por certo, onde também morreram policiais que têm sido incorporados nas linhagens de mártires das respetivas instituições policiais. Vale dizer que, durante tais episódios, houve civis mortos. 
como a figura fantasmagórica da capa de jornal de 1993 com a qual abri este capítulo - aqui, está assegurando uma pedra na mão. Os "cabeças de camiseta" dos anos 1990 já não levam iniciais, como os milicianos dos anos 1980: é uma afronta, como vimos, que fundamentalmente escapa da lógica dos partidos e das vanguardas de esquerda.

\section{Alegria insolente}

Claudia dançava. Às vezes, dançava mascarada entre barricadas e coquetéis molotov. Nascida um ano antes do Golpe de Estado de 1973, morreu em condições similares às de Eduardo Vergara Toledo: faleceu baleada pela polícia, em 11 de setembro de 1998, na población La Pincoya, periferia norte de Santiago. Cinco anos antes, no ex-Instituto Pedagógico, universidade de Eduardo, ela dava início a seus estudos em pedagogia em letras. Assim como ele, foi expulsa do centro de estudos, não por sua militância, mas por reprovar pela terceira vez uma mesma disciplina. Em 1995, começou sua formação em dança na Universidade de Humanismo Cristiano, no centro da cidade. No entanto, continuou a visitar "El Peda" para rever amigos, para seguir as coreografias fugazes e anônimas das lutas callejeras'30. Ao contrário de Eduardo, Claudia não era próxima do marxismo, tampouco da igreja católica, mas sim do anarquismo. Junto a outros amigos da faculdade, atiravam panfletos no ar e erguiam barricadas, tal como os jovens lutadores dos 1980, só que com ideais libertários.

Os confrontos de Macul com Grecia dos quais Claudia participava eram e são forma de engajamento político minoritário: são poucas e interessam a poucos (salvo, à polícia). Na década de 1990, tais formas de

130 Sigo a reconstrução histórica de Gabriela Barría (2012), que estudou os casos de Claudia López e outros dois jovens anti-capitalistas: Luis Silva, de 14 anos, da Villa Francia, morto com um tiro na cabeça, em 1988, e Jhonny Cariqueo, que faleceu em 2008, com 23 anos, após um ataque cardíaco causado pela violência policial na comemoração do Dia do Jovem Combatente na comuna de Pudahuel. A pesquisa foi confeccionada para seu TCC em história na Universidade do Chile, sob orientação do professor Gabriel Salazar, defendida em 2012. O trabalho de Gabriela, como o de Nicolas Díaz, citado no caso dos Vergara Toledo, destacamse pela seriedade, compromisso e rigor investigativo, ainda que desenvolvidos quando muito jovem. Ambos os trabalhos citados seguiram as metodologias da Nueva Historia Social, dando preferência ao estudo da história recente e das histórias orais. 
rebeldia deram um espaço de participação direta aos jovens que repudiavam as lógicas partidárias. A redemocratização chilena trouxe o paradoxo da desmobilização: onde estão as multidões que se organizaram massivamente nos anos 1980 para exigir a saída do ditador? Na avaliação da esquerda, a indiferença e apatia política, sobretudo juvenil, era sintoma de valores como o consumismo e individualismo promovidos pelo neoliberalismo imposto pelo regime pinochetista e perpetuado pela Concertación ${ }^{131}$. Porém, a sinalização para a participação juvenil desde o governo de Aylwin foi, no mínimo, ambígua. Por intermédio de uma retórica conciliadora avessa ao conflito social, contrária à dialética e à luta de classes, em momentos de crise econômica e de desemprego, o governo considerou que o mais apropriado era entregar um cartão nacional de descontos em produtos e serviços ("Tarjeta Joven”) desenhada para os jovens do país. Não emprego, nem educação, mas consumo (Acevedo, 2015).

Nesse cenário, a luta callejera tornou-se espaço no qual podiam ser levadas a cabo críticas contra o capitalismo, especialmente para pequenos coletivos arranjados por meio de vínculos afetivos e de confiança (Barría, 2012). Desses coletivos, faziam parte jovens engajados, mas não necessariamente militantes, como Claudia, ou como Johnny Cariqueo, luchador social e rapper, que, com 23 anos, morreu de um ataque cardíaco causado pela violência policial quando preso nos atos comemorativos do Dia do Jovem Combatente de 2008, na comuna de Pudahuel.

\footnotetext{
${ }^{131}$ A desmobilização política dos anos 1990 transformou-se em um dos objetos prediletos das ciências sociais chilenas: a democracia deu passo a uma "sociedade da indiferença", onde as pessoas deixaram de se interessar por assuntos políticos. Assim, consolidou-se uma descrição de época como de apatia geral, que contrastava com os "gloriosos" anos 1980, de organização política popular contra a ditadura militar. É nesse quadro que as multitudinárias mobilizações estudantis de 2006 e 2011 foram lidas, como um "acordar" da sociedade, o regresso da política e da rua, depois de décadas de silêncio, especialmente dos jovens. Em tal leitura, expressões minoritárias de fazer político apartidário como as aqui relatadas, por certo, não prestavam significância. Acerca da discussão sociológica dos anos 1990, ver: Valdivia (1997). Para uma crítica dessas leituras que idealizam as resistências de 1980 e veem só desintegração, anomia e consumismo no presente neoliberal, ver: Han (2010). Para uma crítica dessa leitura, muitas das vezes atrelada às noções de segregação residencial, ver: Roca (2016).
} 
No funeral de Johnny, havia um caixão enfeitado de flores; no fundo, um cartaz em letras pretas e vermelhas acautelava: "Porque los combatientes como Jhonny viven en la lucha del pueblo organizado. Haremos que tu muerte no sea en vano"132. Esses jovens não militantes mortos pela polícia começaram a ser lembrados na rua, durante embates com a polícia, por una miríade de grupos e organizações dedicadas à luta social, desde coletivos hip hop até grupos anarquistas. Foi nesse contexto que, na esquina de Macul com Grecia, ao longo dos anos 1990, passaram a se dar o encontro de jovens das mais diversas agrupações culturais e políticas: "Varios eran anarquistas, y otros éramos marxistas, pero no teníamos problemas en luchar juntos, costumbre unitaria que venía de los tiempos de la Resistencia Autónoma Estudiantil, y que luego se prolongó con la Coordinadora Revolucionaria del Pedagógico" (Barría, 2012, p. 294).

Na noite de sua morte, Claudia chegou até La Pincoya com um amigo da universidade, pois haviam sido convidados por outros jovens para participar dos atos de recordação do 11 de setembro de 1998. Nenhum deles morava nessa población emblemática, como eram chamados os bairros nascidos da organização popular com apoio de partidos de esquerda ao longo dos anos 1960. A "visitação" de territórios como aquele para datas de recordação era frequente entre jovens que buscavam ter a chance de ativar sua memória e enfrentar a polícia. Esse 11 foi o último dela e o último a ser feriado nacional: afinal, em 1981, Pinochet decretou o dia do Golpe de Estado como o Dia da Libertação Nacional. Depois, em 1998, instaurou-se o Dia da Unidade Nacional a ser comemorado a cada primeira segunda-feira de setembro, data que não teve repercussão pública - finalmente abolida em 2002. Entre a pretendida libertação e a desejada unidade nacional, o que até hoje continua sendo organizado por mulheres, homens, adultos e jovens, a cada 11 de setembro, em diversos pontos de Santiago, são passeatas, atos culturais, instalações artísticas - e, também, os embates com a polícia.

Depois da morte de Claudia, autoridades da Universidade Academia de Humanismo Cristiana, junto com a sua família, organizações de defesa dos direitos humanos e representantes do PC chileno (onde militava seu pai),

132 Imagens do minidocumentário Jhonny Cariqueo: Memoria y Resistencia, de Lumpen Crew Ediciones (sem data). Disponível em: https://bit.ly/2jUtXWn. Acessado em: 02/4/2019. 
pediram à Corte Suprema para que fosse designado um ministro especial para acompanhar as investigações sobre o homicídio da jovem. Tal petição justificava-se pela comoção pública que sua morte havia causado e nas testemunhas que afirmavam que Claudia havia sido morta pela polícia, depois de abandonada na rua com graves ferimentos causados por espancamento. Bombeiros chegariam apenas a pedido dos vizinhos. No entanto, a jovem faleceu com 26 anos a caminho para o hospital. Até hoje ninguém foi culpado por seu assassinato. O governo da época, presidido pelo democrata cristão Eduardo Frei, negou que a polícia houvesse disparado qualquer tiro para reprimir os protestos daquela noite, quando só em Santiago 327 pessoas foram presas pela polícia.

Um pequeno grupo de pessoas reúne-se na frente da escola de dança. Os vi por acaso quando passava de bicicleta de regresso à minha casa depois de ter acompanhado o ato organizado pelo Museu da Memória para recordar os executados e desaparecidos políticos. É 11 de setembro de 2017. Claudia morreu há 22 anos. Desacelerei e vi o seu nome escrito em uma faixa. A jovem era uma ausente presente na serenidade da contemplação silenciosa das velas acessas no meio da noite. Pequeno fogo, fogo tímido, quando comparado com outros fogaréus acessos, também para recordá-la. Passo, então, do memorial oficial à memória rebelde. Nesse mesmo dia, no interior do "El Peda", cinco corpos mascarados avançam carregando nas mãos garrafas cheias de gasolina. Vestem impecáveis camisetas brancas, mas não no torso e sim na cabeça. Rostos cobertos com esmero: as peles do rosto, das mãos e do corpo estão completamente cobertas.

Pela legenda que acompanha a fotografia publicada na Internet, sabemos que são mulheres. Uniformadas, vestem calças e casacos com capuz pretos. Uma delas carrega nas costas a figura de um rosto pálido, o sorriso tímido e os cabelos cumpridos. É Claudia. Eu não a conheci pessoalmente, mas por algum motivo, de imediato, sei que é ela. Tenho visto esse retrato nos mais diversos lugares, desde há tempos. Em um movimento inverso a das mães, esposas e filhas dos desaparecidos que carregavam as fotografias de seus parentes no peito, perto do coração, o retrato de Claudia vai nas costas, gesto pouco frequente entre mascarados. É inovação. É criação. 
"Claudia López en la alegría insolente de la revuelta presente" - assim se lê na faixa que dois encapuchados mostram para a lente fotográfica, posando no interior da universidade. Lá fora, na rua, no lugar das barricadas fotografadas pelo jornal em 1993 alçadas em memória de Eduardo e Rafael, mais uma vez, há pneus ardendo ordeiramente um ao lado do outro, envoltos por uma enorme fumaça escura. De costas para a câmera, uma mascarada observa de pé a cena, em um instante de calma, de braços abaixados. No fundo, na esquina de Macul com Grecia, carros desviam. Mais uma vez, na mesma esquina, barricadas, fogo e asfalto. Mais uma vez, mascarados à espera dos pacos (policiais).

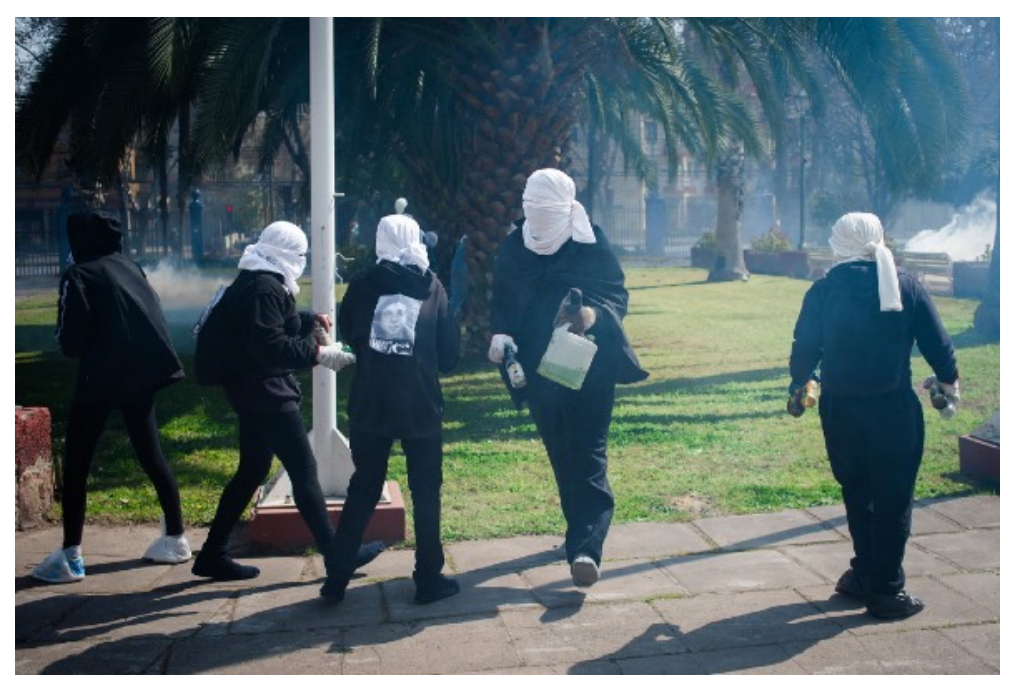

Figura 13: Encapuchadas (Cosmopolita Flickr. 2017)

\section{Às barricadas}

O desejo de interromper a circulação da cidade, como ação de rebelde, não é nada novo. Na imaginação histórico-política da esquerda, a barricada constitui a materialização simbólica do ato insurrecional (Löwy, 2009, p. 13). Sobre barricadas, Engels (2015), em 1895, à luz da derrota da Comuna de Paris no século XIX, negava a esses artefatos qualquer eficácia tática, argumentação fundada na constatação dos avanços tecnológicos policiais da época, como a granada de tiro - que, em um segundo, podia destruir a mais elaborada das barricadas. A persistência dessas formas materiais de levante, até hoje, mantém relação com a eficácia simbólica: persistem não pela capacidade de 
derrubar governos, mas por congregar mediante um sentimento de unidade na luta, sem precisar de lideranças ou responder a um plano estratégico maior. Ao estabelecer uma meta de ação comum, as barricadas possibilitam a construção de uma identidade legível: nós, que construímos barricadas, e os outros (Hazan, 2015; Gould, 1995; Traugott, 2010).

Na Comuna de Paris, por exemplo, foi por meio desses artefatos que homens e mulheres desafiaram a capacidade das autoridades francesas de se imiscuírem em qualquer recanto da cidade. Acesso denegado que, como sabemos, foi respondido com uma radical reforma urbana que teve por objetivo maior destruir a Paris da classe operária e instituir uma cidade de camadas sociais territorialmente arranjadas. Sobre as ruínas, grandes avenidas e bulevares foram construídos para viabilizar fluxos de circulação, vigilância e controle social133.

Se no geral as barricadas buscam impedir a passagem das forças policiais ou oponentes, em Santiago, na esquina de Macul com Grecia trata-se de algo um tanto quanto diferente. Voltemos para a matéria jornalística de 1993 com a qual abri este capítulo: "Primero fueron lanzados trozos de madera encendidos al medio de la calle, con el fin de obstaculizar el tránsito y lograr la presencia de Carabineros". Estruturas precárias e móveis de pneus, lixeiras, sinais, escrivaninhas e cadeiras, barricadas que, ao contrário das parisienses, servem a três propósitos: impedir a passagem dos carros e ônibus, como meio de recordação dos jovens combatentes e como sinalização material que, justamente por isso, pretende-se atrair a chegada da polícia para o embate. Isso à primeira vista pode parecer um contrassenso, porque não se trata de repelir a chegada das forças da ordem, mas de provoca-las. No livro anônimo Macul con Grecia que recopila histórias mascaradas, lê-se sobre a tensa espera dos policiais:

Poleras cubriendo rostros, fuerte olor a bencina, gritos rompiendo el silencio, renacen lxs compañerxs que no están, panfletos surcando el cielo, neumáticos en llamas cortando las calles, señaléticas arrancadas de cuajo, la espera, la expectante y tensa espera... suenas las sirenas y aparece el horrible y blindado verde de la represión, el objetivo está en la mira y el odio fuertemente empuñado, vuelan las molotov cortando el aire, retumba el estallido del cristal: !FUEGO! (ANÔNIMO, 2006, p. 6).

133 Refiro-me à conhecida reforma urbana impulsada por Georges-Eugène Haussmann. 
Ora, somente com a presença da polícia é possível completar o ato de recordação dos mortos e desaparecidos, ou seja, apenas com a luta corpo-acorpo contra o Estado. Trata-se de uma contra-violência que ataca, no presente, os corpos policiais a fim de vingar e manter a memória daqueles ausentes que caíram quando lutavam na rua contra a ditadura e, depois, contra a "farsa" democrática. A luta política, como entendida por esses atores políticos, precisa de seu adversário materializado: a polícia é o Estado encarnado. A polícia de hoje é a mesma polícia repressora de antes, assassinos dos irmãos Vergara Toledo, explicou um mascarado sobre os embates no Dia do Jovem Combatente na Villa Francia, em 2009, no parágrafo que cito no que segue ${ }^{134}$. O propósito é se revoltar para deixar claro a esses conchasumadres (filhos da puta) que "ainda estamos vivos":

Con mis compañerxs estamos aquí dando frente a la misma represión fascista que asesinó a nuestros compañeros, vecinos y amigos, los hermanos Vergara. Con una mochila cargada con 8 molotovs, 2 de nosotrxs con armas de fuego y el resto de lxs compañerxs con boleadoras, hondas, palos y camotes, estamos listxs para luchar cara a cara con lxs perrxs del patrón. Puedo escuchar mi corazón entre la balacera, no estoy aquí sólo para conmemorar a los hermanos Vergara, estoy aquí para recordarles a estxs conchesumadres que aun estamos vivxs y no tenemos intensiones de callarnos sumisamente... me cuesta respirar por debajo de la capucha, los minutos parecen segundos y estoy tan cerca de lxs asesinxs que puedo sentir su olor (ANÔNIMO, 2009, s/p).

"Posso sentir o cheiro dos assassinos". Trata-se de imagem forte. Nos embates entre manifestantes e a polícia, recorte temporal em que os minutos parecem segundos e os corpos fugazes estão carregados de adrenalina, o Estado é apercebido como inimigo palpável, corpo fedorento. A referência ao

${ }_{134} \mathrm{O}$ relato anônimo que cito foi construído de forma testemunhal, em primeira pessoa. Porém, cotejando algumas informações, parece constituir uma ficção sobre fatos reais. Ele menciona o ferimento de uma criança de 12 anos por bala de borracha disparada pela polícia, evento que ocorreu no Dia do Jovem Combatente em uma población em Pudahuel - não em Villa Francia. Mas o texto interessa mesmo assim pelas descrições muito parecidas às que, mais à frente, apresentarei, a partir das pesquisas de um sociólogo e de sua observação participante em Villa Francia, em 2012. Também é de se notar a linguagem inclusiva de gênero (x). 
cheiro não é tão estranha assim quando considerado que os pacos, policiais, tem sido chamado durante décadas de chanchos não só no Chile135.

Sobre os confrontos entre jovens mascarados, a polícia e o olfato, vale a pena trazer um poema de Juan Carreño (2007), Poema escrito por más de cien jóvenes la noche del 11 de septiembre del 2005 en avenida Santo Tomás con La Serena, La Pintana, escrito com fundamento na transcrição do áudio gravado pelo poeta em seu bairro, em uma noite de 11 de setembro em El Castillo, población periférica e pobre de Santiago, sem uma tradição de esquerda de origem (de fato, as moradias foram construídas pelo Ministério da Vivienda durante o regime de Pinochet). Conforme explica em uma nota de roda pé, são jovens não muito ligados à arte: "matan como el que mea” [matam tal como fazem xixi]. Contudo, se fazem parte dessa noite de recordação, onde domina a desaprovação geral contra a polícia - para além dos discursos militantes da polícia como o Estado -, aqui, o ódio à polícia se justifica porque é a polícia a força da ordem que reprime e mata os pobres para assegurar que os privilégios dos ricos continuem tal como estão, seja na ditadura, seja na democracia.

O poema é uma concatenação de expressões verbais da fala popular chilena, que mal poderia ser entendida pelo leitor brasileiro ou um chileno de classe média ou alta (eu mesma não entendo algumas expressões). Contudo, as falas corais transcritas, no seu atropelamento, via sucessão rápida e confusa de versos, cheias de signos de exclamação, nos aproximam da alegria insolente do enfrentamento. A busca por pedras (camotitos), a espera pelos policiais (pacoh), os gases lacrimogêneos, os palavrões de conotação sexual (tula, chuchasumare, culiao, ñato), a organização efêmera (cadê as pedras, cadê o limão para acalmar o ardor), a comemoração dos movimentos certos, o alerta da chegada dos camburões, das táticas policiais no meio da noite, as estratégias para fugir. Há também referências ao odor da polícia: a fezes, porque "cagados" de medo do ataque dos mascarados que, além de pedras,

$135 \mathrm{Na}$ Inglaterra, usa-se a palavra pig desde o século XIX para dizer respeito aqueles que lidavam como o crime "sujo"; mas, rapidamente, o termo ganhou a acepção da polícia como aqueles que de forma recorrente acometiam abuso de poder (Neocleous, 2010, p.87-88). Já nos Estados Unidos, chamar aos policiais de pig, tinha a ver com um processo de desumanização, ou com a ideia popular de que os agentes da polícia se caracterizariam por atributos tais como a cobiça, a gula e a preguiça (Tipler e Ruscher, 2014, p.215). 
têm armas de fogo (fierros). Cheiro a excremento, a genitália (hediondo a pico): injúrias escatológicas para aqueles que cuidam do lado mais escuro do Estado, a polícia, que na defesa da paz, violenta:

!E! !e! !e! / !Vamoh pallá po! / !Vamoh po cabroh a camotiar a loh pacoh culiao! / !Too pa delante! / !Tan viendo purah torta jileh culiao! / !Ándate e guelo loh fantahma! /!Too parría! / !Vamoh vamoh vamoh! /!Cuidado con el humo oye! / !Chúpenlo rico chuchasumare! !Tení limón? / !No son pa la ensalá Pelao Chico! /E! ! e! !e! / !Alguna gueá pa prender! /!Ehtán acuertaleo loh jileh culiao! / !Un camotito po Chorrillano! !Tan / !tan tirao! /!Vienen vienen! / !Agárrame la tula paco culiao! /!Faltan piedra loco! / ¿Dónde hay piedra guon? / !Llapo Deivi, tai máh duro! / !Aquí hay harta piedra Jaimito! / !Lorea Jaimito! / !Somoh máh! /!Da la cara paco conhetumadre! /!Jote culiao! / !Quien apaña? /!Tira un mojón mijito! /!No arranquen po loco! / !Sigan po cabroh! / !Sigan! / ! Buena guacho! / !Bien Llon Lenon! / !Ese culiao e hijo e la Glai Marín guon! /!Si viene la zapatilla no se puee meter pal pasaje! / !Cárguense too!/!Chupa loh cocoh lonlli chuchetumare! / !Tiren de mallaa embarao culiao! !Viene la zapatilla guon! / !Acuartélense cabroh!! Somos caleta pa una zapatilla loco! / !Qué guea? / Achunchan? !El humo culiao brígido guon! !Te guhta el ñato perro culiao! !Cómo te callai gallo! !A la guan tu tri! !Chupa la pichula paco chuchetumare! / !Alúmbrame el hoyo caaallo! / !Patéala patéala! /! Too armao muchacho too amao! / !Bajémole loh fierroh!!Creen que no loh vimoh jile chuchesumare! / !Jaimito tiene el meio ojo! /! Me loh prehtó el Huguito!!Chucha! / !Van a salir por acá! !Te ehtai cagando terrible hediondo paco culiao!! Agarren piedra guon agarren piedra! / !Quién tiene una piedra que me regale! / !Mamá ehtá presa! / !Paco tonto! / !Y la conchatumare! !El olor te sapió paco culiao!/ !Andai hediondo a pico! !Aguja aguja! / !Yo te pago el sueldo! / !Yo que compro hierba! !Oye tu mamá eh mi señora paco culiao! / !Se llama Teresa y lo endereza!!Un doh treh por loh pacoh que ehtán en la ehquina! /!Apunta pacá culiao! / !Te tengo entero funao paco y la conchetumare! / !Paco culiao a pila! / !Tai puro vendiendo pluma! (Carreño, 2010, p. 9).

Na luta callejera, corpos anônimos em aceleração, em disposição física, emocional e mental. Carregados de vigor, corpos em adrenalina, reunidos para recordar aos jovens assassinados no passado pela polícia. Uma memória que implica sair na rua, uma memória por meio do corpo ("hay que poner el cuerpo") que soma-se aos embates com outros corpos, todos mascarados, contra um inimigo comum: a polícia.

Isto é o que os jovens da esquerda extraparlamentar no Chile chamam de "memória ativa". Acerca disso discorria Raúl, que nasceu em 1990. De família de classe média baixa, pais que não se interessam por política e um 
avô que ainda tem uma fotografia de Augusto Pinochet na sala de sua casa, na población La Pincoya, mesmo bairro onde morreu Claudia López. Ele, junto com seus companheiros de escola na periferia, ia até o centro da cidade para participar dos multitudinários protestos estudantis da Revolução dos Pinguins, em 2006. No final da passeata e dos discursos, as barricadas começavam. Se elas tinham sido experiências importantes em 2006, em 2011, nos protestos estudantis, passaram a ganhar uma dimensão impressionante: "era la cagada" 136 . Entre as barricadas, Ramiro reportava sentimentos de alegria insolente com uma motivação política: lutar pela educação pública e recordar as efemérides dos jovens militantes mortos no passado pela polícia:

[...] en el fondo como que uno le toma el gusto al enfrentamiento con la autoridad, así como a esa adrenalina, hueón, es súper adrenalínico sentir esa hueá que tenís que arrancar, que podís cortar la calle, que podís prenderle fuego a la hueá rápido y podís virar y nadie te va a decir nada y más encima lo estai haciendo por una hueá mayor po, mantener viva esa identidad combativa. Es una exaltación de muchas cosas, te ponis como hasta más agudo en tus movimientos, en tu forma de pensar, en lo rápido que estai, tenís que estar despierto po, tenís pocos recursos, tenís poco tiempo, entonces tenis que andar muy despierto po y todos re excitados con la hueá, te ponis contento, ¿cachai? Más encima vas hermaniando más con la gente, buenos amigos te vai haciendo en esa (Raul, entrevista em 2016).

\section{Observadores mascarados}

5 de novembro de 2012. Mais uma efeméride da morte de Araceli Romo e Pablo Vergara Toledo em Villa Francia. Além de Eduardo e Rafael, a família Vergara Toledo sofreu a perda do filho mais velho, Pablo, também militante do MIR. Três anos depois, em 5 de novembro de 1988, o corpo decepado de Pablo foi achado junto ao cadáver de Araceli Romo, no sul do país. Ambos tinham 25 anos. Pablo havia regressado naquele ano, clandestinamente, ao Chile, depois de ir embora para a Espanha com a sua irmã Ana, como medida de segurança logo depois dos assassinatos de Eduardo e Rafael. Algumas histórias contam que Pablo e Araceli eram compañeros nas duas acepções do termo, na militância e no amor, e que

136 "Cagada”, aqui, poderia se traduzir como "muito foda". 
haviam se conhecido em Cuba, onde teriam recebido treinamento de guerrilha. As notícias informaram de mais dois miristas mortos ao tentar derrubar com explosivos uma torre de transmissão elétrica, tática de sabotagem corriqueira naqueles anos ${ }^{137}$.

No entanto, não foram poucos que desconfiaram da versão policial. Os corpos de Pablo e Araceli foram dispostos na cena do crime para parecer que morreram em um ato de sabotagem. No funeral de Pablo Vergara Toledo, mais uma vez, houve lágrimas, lenços, flores e mascarados. Punhos erguidos, gritos, a foice e o martelo. A polícia, novamente, acompanhou de perto as atividades fúnebres em Villa Francia e, depois, no Cemitério Geral de Santiago, onde, finalmente, foram reunidos os corpos de Pablo, Eduardo e Rafael. Em 1991, a Comissão da Verdade e Reconciliação reconheceu como vítima da violência política somente Rafael. Eduardo não foi catalogado como tal porque foi considerado um terrorista que morreu quando atirava contra a polícia, em confronto. O mesmo ocorreu com Pablo, quem teria sido morto, conforme a versão da polícia, quando tentava derrubar uma torre de transmissão elétrica. Por esses dois filhos mortos na luta contra a ditadura, seus pais não receberam compensações econômicas da parte do Estado.

Nessa nova recordação, no bairro onde ocorreram as mortes de Pablo e Araceli, Villa Francia, entre a multidão, há alguém que participa e observa: um jovem sociólogo chileno, Angelo Montoni (2015), que faz pesquisa de campo para o seu doutorado na França. É uma noite mais escura do que o normal. Cortes de luz pressagiam os eventos de recordação que acontecerão em breve:

\footnotetext{
137 Acerca dos "apagones", Manuel Fernando Contreras, militante do PC Chileno durante o regime dictatorial estabeleceu em uma entrevista recente uma analogia entre o ato de usar capuz e os cortes de luz: "Casi todos los 11 de septiembre hay apagones de luz, en todos se tenía particular consideración en tirar unas cuantas torres abajo, y ¿sabes por qué? porque la oscuridad permitía que la gente saliera a la calle. Era un encapuchado, un gran encapuchado, de cientos de miles de personas que no salían a dejar la cagá', salían a botar una dictadura y no romper quioscos, ni romper semáforos. En ese momento, todos requeríamos ponernos una capucha, porque estábamos ante una dictadura, no estábamos ante una democracia como ahora. Era la gran capucha legítima, en ese momento, eso era el apagón de luz, las dos cosas, demostrar que la dictadura era falible, desde el punto de vista psicológico" (Dinamarca, 2015, s/p). No trecho, Contreras sintetiza a grande crítica da esquerda parlamentar aos levantes dos mascarados: na democracia, não há necessidade de ocultar o rosto, pois está assegurada a liberdade de expressão.
} 
$\mathrm{Na}$ escuridão, nada é visível. Só quando o primeiro coquetel Molotov é aceso e cai sobre os pneus empilhados no meio da avenida 5 de Abril, as poderosas chamas revelam as silhuetas de jovens, 30, 40 ou 50 pessoas, na frente de mais de mil pobladores que batem palmas 138. As palavras de ordem se seguem umas às outras, como músicas gritadas pelos jovens e aclamadas pelo público que, à distância, assiste ao show. Os jovens atiram panfletos com frases que recordam o propósito da ação: não esquecer dos mortos do povo, exigir a libertação dos presos políticos e organizar-se frente às injustiças do sistema (Montoni, 2015, p. 181, tradução minha).

Controle territorial: os mascarados movem-se sem problemas na escuridão, erguem barricadas para atrair a polícia. Gases lacrimogêneos, carros de choque e jatos d'água não demoram a aparecer, usados contra os moradores-espectadores que, apesar do ar irritante, continuam a observar as escaramuças. Ninguém quer perder a escalada das colisões, assegura o sociólogo. Os policiais, depois do intercâmbio de coquetéis Molotov e gases lacrimogêneos, enfim cruzam a avenida e chegam ao lado dos mascarados: atiram balas de borracha, porradas com cassetetes. Porém, os jovens fogem rápido por pequenas ruas do bairro. Em ato de solidariedade e conivência, os moradores deixam abertas as portas para os mascarados se esconderem, tal como acontecia na ditadura com os jovens de pañuelos bem amarrados ${ }^{139}$.

Não sabemos se dessa vez o sociólogo está mascarado. Conhecidos seus da Villa Francia o apresentaram como militante da esquerda radical. De súbito, passou a participar de reuniões e da preparação de atos comemorativos à memória rebelde e dos enfrentamentos com a polícia. Aos poucos, foi ajustando sua aparência, querendo parecer mais jovem, mais próximo de seus interlocutores: vestiu-se de preto, com calça jeans ajustadas, cassaco com capuz e mochila. Transformou-se - tal como sabem fazer a polícia secreta - em um deles: aprendeu a imitar o "acento nativo", construiu uma identidade falsa e uma biografia credível (Montoni, 2015, p.29).

Dada a observação participante, sente no próprio corpo a “adrenalina” (Montoni, 2015, p.31) expelida ao fugir da polícia junto aos mascarados em protestos. Experiências intensas o afetaram: por que estou

${ }_{13} 8$ Montoni reporta mil espectadores, cifra que assombra, à primeira vista Será que a adrenalina o levou a ver mais pessoas que aquelas que realmente estavam presentes no local? 139 Hoje, ás vezes, os vizinhos abrem as portas nas poblaciones emblemáticas, como Villa Francia, La Pincoya, La Victoria. Às vezes, não - como veremos no próximo capítulo. 
desfrutando disso de forma tão afetiva? Reconhece sentir fascinação pela luta callejera, mesmo desacreditando das concepções políticas da insurreição e da revolta como entendidas por seus interlocutores ${ }^{140}$. Os embates com a polícia oferecem aos jovens, e também ao pesquisador, o prazer da resistência. Aos meios de comunicação, indicam imagens espetaculares; à polícia, a chance de restabelecer a ordem sem enfrentar uma situação de alto risco.

Sobre a adrenalina experimentada nos embates contra a polícia relatada pelo sociólogo Montoni, vale remeter a outro jovem, Carlos, que participou dos protestos estudantis durante o ano 201. Enquanto fotógrafo, saiu às ruas durante enfrentamentos entre polícia e os encapuchados. Ao primeiro impulso de registrar esses eventos com sua câmera fotográfica, ele pretendia seguir o legado dos fotojornalistas na ditadura e retratar a violência policial contra os manifestantes. Mas, logo depois, à medida que foi repetindo sua participação nas mobilizações de rua e, mais especificamente, se aproximando cada vez mais dos mascarados, começou a sentir prazer corporal: a "adrenalina" das escaramuças. Na Revolução do Pinguins, como muitos outros fotógrafos por conta própria que solidarizavam com o movimento estudantil, resolveu retratar com sua câmera o ponto de vista dos encapuchados. Para acompanhar os movimentos dos mascarados, juntamente com sua fusão fugaz e disruptiva, teve que aprender a se movimentar com rapidez e estar sempre alerta. Sentiu junto com eles a emoção de fugir entre gases lacrimogêneos e a camaradagem de avisar aos "cabros" se a polícia de choque se aproximava. Nessa imersão fotográfica, ajudou-lhe sua própria aparência: de vinte e poucos anos, tranças rastafári, tatuagens e piercings pelo corpo, ele próprio disruptivo esteticamente. No entanto, certa feita, um encapuchado desconfiou: quem é você? Sem fotos aqui!

140 Ao ler o trabalho de Montoni, não consegui deixar de pensar em Löic Wacquant (2006) e a sua proposta de "sociologia carnal". Sua análise poderia ter enveredado por esse caminho, em vez de pensar a sua inserção no campo como trabalho dos agentes policiais secretos. Esta comparação resulta, no mínimo, complicada, pelo fato de ser técnica usada pela polícia no Chile para a neutralização dessas formas de dissenso. Ramiro, um dos meus interlocutores, colocou-me a questão de participar nos enfrentamentos na rua, mascarada. Justamente, pela questão das infiltrações, pareceu-me um convite um tanto quanto inconveniente. 
Sem ser cientista social, Carlos diz ter identificado padrões de ação nas passeatas estudantis no centro de Santiago e nas marchas do 11 de setembro, quando a irrupção de grupos pequenos de mascarados faz parte do roteiro. Começa descrevendo os confrontos entre policiais e encapuchados como desordem e caos, imagens usadas há séculos para caracterizar as multidões sediciosas, mas aos poucos passa a discorrer sobre os tempos e a geografia dos protestos, bem como a previsibilidade da revolta:

Después que vai harto tiempo empiezas a cachar como funcionan. Como que todo está así como, no orquestado, pero es como medio ritualesco: la marcha, el lugar donde se va, donde se termina, el escenario, la gente que habla, la gente que espera atrás - que son todos estos locos encapuchados. Como que cachai como funciona y la prensa también, los gráficos se van a la parte de atrás porque en la parte de atrás es donde empieza todo este asunto de locura, cuando empieza a quedar los desórdenes y !Siempre pasa! - no es que [imita uma outra voz]: "!Oh, no! No esperábamos esto". Yo fui aprendiendo y se sigue manteniendo, así como que el esqueleto sigue siendo el mismo (Carlos, entrevista em 2015).

Se "esqueleto" remete a certa estrutura, o termo "ritualesco" vem remarcar na passagem acima o caráter iterativo dos enfrentamentos, repetições que se sustentariam em certos acordos implícitos, mas não inteiramente orquestrados entre os diversos atores que compõem as grandes mobilizações de rua. A ideia de ritual apontada por Carlos, como discutirei na secção que se segue, tem sido utilizada por vários cientistas sociais que tentaram caracterizar a violência entre encapuchados e a polícia nos protestos de rua multitudinários do movimento estudantil, bem como na comemoração da efeméride em datas como o Dia do Jovem Combatente e o 11 de Setembro. É uma expressão, às vezes, usada como metáfora, outras, de modo mais preciso, no sentido mais antropológico do termo. No geral, ela é empregada por aqueles que, em vez de condenar os embates violentos, os tentam compreender eles como dinâmicas de interação social que fazem parte da política nacional. 


\section{Violência ritual?}

Como testemunha dos confrontos entre mascarados e polícia em Macul com Grecia, já há duas décadas, a acadêmica da Universidade do Chile, Olga Grau, discorreu, em 2000, acerca da dimensão ritual das lutas callejeras ${ }^{141}$. Fazendo uso de expressões psicanalíticas, na reiteração dos embates, identificou uma "repetição neurótica": no capuz, um "sintoma”, e na destruição do mobiliário urbano, "catarses" que expunham tudo o que o projeto de redemocratização impulsado pela Concertación de Partidos por la Democracia buscou expurgar da comunidade política nacional, a saber, o conflito e a memórias insubmissas.

Ritual, portanto, que é político, pois re-situava na rua, por meio da perfomance dos encapuchados, o relato sangrento do terrorismo de Estado e da violência contra as dissidências da esquerda radical na transição democrática. Os mascarados entre barricadas e coquetéis Molotov, como fantasmas, discorria a especialista em estudos culturais, impugnavam a governabilidade pactuada pelas autoridades e as elites.

Días de memoria, para hacer memoria. El calendario, el tiempo, efemérides que marcan lo que acontecerá en el espacio. Se actúa la memoria de las protestas, se repite el pasado aunque la repetición sea una forma constreñida, acotada, no popular; se persiste en una forma, se reitera neuróticamente, en el síntoma de la capucha, afirmación de clandestinidad, de un modo de ser cómplices secretos. Escenificación de una habla catártica que tiene obstaculizados los canales de expresión, reprimida por las costras de la frustración y desazón [...] Hay un acostumbramiento a que los hechos deben ocurrir de tal manera, una cierta rutina, hasta una suerte de determinación acotada de los hechos: los carabineros parece concurrir sin pasión, tal vez a cumplir con un rito que se cumple de lado a lado, rito político no negociable, ni pactable, ni transable, fuera de la Constitución (Richard, 2000, p. 202, itálicos nossos).

Na última década, acadêmicos atentos às dinâmicas de confronto nos protestos de rua no Chile elaboraram pesquisas empíricas ou reflexões

${ }^{141}$ O ensaio "El encapuchamiento de la memoria" teve duas circulações importantes: uma acadêmica, por meio de uma coletânea organizada por Nelly Richard, "Políticas y estéticas de la memoria" (2000); e outra mais militante e pública, em Los andamios de la ira, coletânea publicada por Ediciones La Cúpula, nesse mesmo ano, mas com outro título: "Corran los autos o el encapuchamiento de la memoria”. 
ensaístas, enveredando suas análises na chave do ritual (Bellei, 2017; Duarte e Aguilera, 2009; Montoni, 2015; Orellana, 2017; Sandoval, 2014). Alguns deles, para o caso chileno, testaram a pertinência do trabalho de Jeffrey Juris (2005) acerca da tática Black Bloc nos protestos europeus alter-globalização dos anos 2000. Para o antropólogo canadense, as escaramuças entre os manifestantes mascarados e a polícia eram rituais simbólicos de confronto onde era encenada uma violência performática contra a propriedade pública e privada, entendida por seus perpetradores como destruição de símbolos do Estado e do Capital. Embates que são, no limite, ainda rituais, na medida em que há a sobre-estetização da tática (códigos de vestimenta: todos de preto, mascarados, com coturnos), da sedimentação dos scripts (onde se têm definido comportamentos tolerados e proscritos) e pelo fato de ser uma agressão de baixa intensidade, ou seja, não letal e designadamente dirigida contra objetos e monumentos.

Aliás, a tática dos "blocos negros" se diferenciaria da violência política por não pretender a real destruição dos adversários políticos (Juris, 2005, p. 415). Partindo dessa hipótese, poderíamos dizer que, em vez de se planejar um atentado contra o presidente do banco transnacional, por exemplo, destrói-se a vidraça de uma de suas agências bancárias. Portanto, os atos constituiriam encenações dramáticas de posições antagónicas: performance política agressiva, sim, mas não realmente violenta, protagonizada por militantes aguerridos e hiper-masculinizados, sempre dispostos a atirar a primeira pedra.

Abraham Sandoval (2014), no seu estudo etnográfico dos protestos estudantis em Santiago e Concepción, perguntava-se acerca do sentido cerimonial dos embates, que seguiam ritmos, tempos e sequências mais ou menos previsíveis. "Simulacro de combate" (Sandoval, 2014, p. 61), onde cada parte reproduz o roteiro preestabelecido que, ainda aparentando ser fruto de 
colisões totais entre inimigos, não chegam à aniquilação do adversário ${ }^{142}$. Com essas considerações em mente, o antropólogo chileno recupera o conceito de "rituais de rebelião", cunhado por Max Gluckman (pai da Escola de Manchester de Antropologia) para entender os ritos de inversão na África do Sul, onde eram encenadas críticas ferozes à ordem cotidiana - porém, seguindo sempre as regras da tradição e da religião. Tempo-espaço excepcional de transgressão de aparência disruptiva, encenação tolerada de atitudes proibidas no dia a dia, mas que, no final de contas, não pretendem a a subversão do poder em termos estruturais ${ }^{143}$.

Comienzan a salir sujetos de rostros cubiertos que de manera ordenada y planificada comienzan a lanzar primero piedras, a rayar los muros [...] se retiran y una nueva oleada de jóvenes más atrevidos que los primeros, con pequeñas botellas de jugo transformadas en maniobrables bombas molotov arrojan sobre el carro lanza aguas de Carabineros. Van a lo menos una decena de proyectiles incendiarios lanzados, no todas alcanzan su objetivo [...] De un momento a otro, estos jóvenes encapuchados que llegaron de manera repentina y coordinada, de igual forma se disponen a retirarse. No duró todo el evento más de 10 minutos, entre repliegues e insultos hacia la policía, que por ese entonces ya se encuentran mas que acostumbrados a los mismos gritos, los mismos gestos (Sandoval, 2015, p. 64, grifos meus).

Em consonância com as leituras funcionalistas caras à antropologia da primeira metade do século passado, para as quais os rituais são reflexo e reforços de arranjos sócioe estruturais existentes, Sandoval (via Gluckman) concluía que as lutas callejeras eram um tipo de "válvulas de escape y elementos que contribuyen al reacomode de las estructuras sociales

\footnotetext{
142 É curioso, mas Abraham Sandoval e Angelo Montoni participaram dos enfrentamentos com a polícia durante suas respetivas pesquisas. Ambos descrevem a sensação de adrenalina e fervor ao fugir das forças da ordem ou de atirar pedras contra o camburão ao lado dos mascarados. Será que há uma relação entre gênero do pesquisador e metodologias de investigação? Será que há uma afinidade entre a figura do aguerrido manifestantecombatente e o etnógrafo intrépido, disposto a participar de tudo para conseguir a desejada "imersão total" no mundo do outro?

143 Entre os rituais analisados por Gluckman, estavam aqueles dedicados à deusa Nomkubulwana, na região da Zululândia, na África do Sul, onde as mulheres passavam a encenar atividades ligadas à agricultura, normalmente desempenhadas pelos homens. Vestiam-se como os homens e performavam o gênero; mas, em outras cenas, despiam-se de toda a roupa e se comportavam de modo exageradamente lascivas.
} 
sometidas a fricción" (Sandoval, 2015, p. 84). Mas esse pesquisador não seria o único a se lembrar do antropólogo britânico.

Nicolás Orellana, que em 2017 defendeu seu doutorado em ciência política na Universidade Católica de Louvain, também discorreu sobre os protestos em Santiago, mais especificamente sobre os embates entre a polícia e os mascarados, ações que sem causar dano nem medo real, também podiam ser pensadas como rebeliōes rituais (Orellana, 2017, p. 347). Trata-se, para ele, de uma farsa temporal em que são representadas posições antagônicas radicais que não pretendiam a transformação da ordem vigente. Nesse caso, a ideia de ritual serve ao autor para explicar o que ele entende como ineficácia revolucionária da "ação encapuchada": embates esperados e tolerados pelas forças de ordem, comunidades contingentes à situação social dos protestos, porém, sem a capacidade de pressão e de negociação por estarem desarticuladas da política partidária e dos movimentos sociais ${ }^{144}$. Em tal sentido, conclui o autor, aos encapuchados só lhes restam as catarses simbólicas (Orellana, 2017, p. 372) que, mesmo sendo ineficazes em termos de conquistas políticas, possibilitam a re-atualização de compromissos militantes ${ }^{145}$.

Filiando-se à tradição historiográfica chilena iniciada por Gabriel Salazar, Angelo Montoni (2015) também discorreu sobre a ritualização da

$144 \mathrm{Na}$ linha da ineficácia política, um outro pesquisador, o historiador da Universidade Alberto Hurtado, especialista em história social da educação, Luis Thielemann concluía que as escaramuças entre os mascarados e a polícia derivaram para um "ritual prisionero de sus propias limitaciones, predecible, autocomplaciente y alienador para efectos de la rearticulación de movimientos de mayor alcance tanto numérico como estratégico" (Toro, 2018, p. 145). Transgressões promovidas por uma esquerda radical fragmentada que, no final das contas, não conseguem uma mudança concreta no sistema político. Trata-se de embates ritualizados que, antes de contribuir para uma sociedade mais justa e deocrática, aguçam o processo de criminalização do movimento estudantil. Parece-me interessante essa chave de crítica vinda da esquerda partidária por meio do conceito (ou metáfora) do "ritual".

145 Chama atenção que este autor crê ser o primeiro no Chile em avançar nesse tipo de análise, que define como uma "ousadia" de sua parte. Ele prossegue a análise através de Victor Turner, antropólogo de uso corriqueiro nos estudos de movimentos sociais preocupados com seus aspectos performáticos e ritualísticos. Ritual também é, para ele, uma forma de escapar das interpretações na chave analítica da anomia e desintegração social, questão, aliás, que também enfatizavam Montoni e Sandoval. 
"violência política popular"146. A falta de mecanismos sociais de controle da raiva em bairros pobres, gerada pelas injustiças sofridas no cotidiano da população periférica, estaria propiciando a radicalização ${ }^{147}$ da juventude, o que se expressa na força identitária, estética e ética da luta callejera. São territórios com um passado organizacional e militante de esquerda, onde abrolha uma "moralidade radical" que entende a luta direta contra a autoridade como única forma correta (consecuente) de combater o neoliberalismo. Em vez de Gluckman ou Juris, é a partir do filósofo francês, René Girard, que Montoni reflete não só acerca das dimensões rituais como também sagradas dos embates descritos na Villa Francia. Na recordação ativa e pública dos jovens combatentes assassinados pela polícia no passado, nota uma vontade de vingança: é nesse processo que os agentes da polícia, homens e mulheres fardadas de carne e osso, transformam-se em bodes expiatórios (victime émissaire) a serem sacrificadas (Montoni, 2015, p. 319)148. O ferimento e/ou o aniquilamento de policiais, de seus corpos, não é simulacro: é o desejo articulado em discursos e embates como modo de ajusticiar os combatentes assassinados no passado recente.

\footnotetext{
146 Violência política popular é um conceito cunhado por Salazar (2006), um dos mais afamados historiadores de esquerda no Chile. Na contramão daqueles que identificaram na revolta popular apenas anomia e desintegração social, Salazar chama a atenção para repertórios de contestação de longa duração, especificamente em relação aos movimentos de moradia e operários ao longo do século XX. Salazar é referência importantíssima para várias gerações de historiadores formados na Universidade do Chile e que advogam por uma história social do mundo popular. Ver: Salazar (2006).

147 Por radicalização, Montoni (2015) entende a disposição discursiva e o ato de engajamento em atividade política fora dos canais institucionais de participação e de caráter ilegal pela ativação da violência como repertório político.

148 Montoni (2015) mobiliza a ideia de "bode expiatório" para pensar o assassinato de militantes de esquerda por parte de agentes da polícia política de Pinochet: os "extremistas" como vítimas a serem eliminadas para a preservação da nação dos perigos do marxismo. É de se notar, contudo, que a ideia de bode expiatório não chega a ser aprofundada em sua tese, sobretudo se considerarmos a complexidade da obra de René Girard (2008).
} 


\section{Ação direta, desfiguração e iconoclasmo}

Em 1998, ano dos protestos alter-globalização em Seattle, o antropólogo australiano Michel Taussig publicou um ensaio sobre a transgressão na religião ${ }^{149}$. No texto, comentava da assombrosa capacidade dos antropólogos para interpretar os rituais mais perturbadores do mundo como transgressões que, em vez de conflito, vinham a reforçar a ordem política e cósmica das coisas. Circuncisões, escarificações, mutilações, imolações, ou seja, toda uma série de desfigurações inscritas na superfície da carne e, portanto, impregnadas pela dor, sangue e êxtase, na análise de antropólogos como Max Gluckman ou Victor Turner, eram purificadas e apresentadas à audiência acadêmica como "rituais de rebelião" ou "experiências liminares", toleradas e prescritas pela religião e pela tradição, logo, úteis à preservação e reprodução da sociedade. Todos esses excessos de corpo eram encaixados na mesma explicação: eram fenômenos que apesar de suas formas disruptivas, no fundo, contribuíam para a preservação da estrutura e da ordem social150. Para Taussig, chegava a ser irritante que, uma e outra vez, distintos autores chegassem à mesma conclusão acerca dos ritos de inversão influenciados pelas leituras estrutural-funcionalistas. Com esse pano de fundo, ele se perguntava: e se esses instantes intensos de transgressão, marcados pelo sangue, a carne e a violência, honrando as divindades, com todos os seus excessos e as distorções, fossem momentos para acenar em direção a um mundo diferente, ao mesmo tempo terrível e maravilhoso? (Taussig, 2006, p. 160). O seu convite era para que pudéssemos olhar nos corpos, nas suas convulsões, nos excessos e na indeterminação de certas práticas ligadas ao sacro. É necessário pensar nas transgressões a partir de sua etimologia; passar o limite, ir além.

\footnotetext{
149 Refiro-me a Trangression, ensaio primeiramente publicado em Critical Terms for Religious Studies, editado por Mark C. Tylor em 1998, mas que, logo depois, seria publicado em uma versão nova pelo próprio Taussig, no seu livro Walter Benjamin’s Grave, em 2006.

150 Em History as Sorcery, Taussig já havia desenvolvido sua crítica às leituras funcionalistas do ritual: "Anthropology has bound the concept of ritual hand and foot to the imagery of order. It is said to be a celebration of order and a declaration against indeterminacy in whose invariance lies the foundation of social convention and "the sacred" itself" (Taussig, 1984, p. 109, grifos meus).
} 
No centro histórico de Santiago, na esquina das avenidas Alameda e Ricardo Cumming, um grupo de pessoas avança pela frente da igreja La Gratitud Nacional carregando um Cristo crucificado de quase dois metros de altura. Tal como os "capirotes" usados nas festividades de Semana Santa, em algumas cidades espanholas, ou os "farricocos" da Procissão do Fogaréu na cidade de Goiás, aqueles que transportam a figura seguem com seus rostos ocultos com pañuelos, camisetas e cachecóis. É 9 de julho de 2016. Apesar das aparências, não se trata de uma procissão litúrgica. Os mascarados, logo depois de removerem a escultura do altar, carregaram-na até a rua para, em seguida, deitá-la de bruços no chão; em vez de adoração, a figura de gesso foi pisoteada até se desmembrar inteira, até que seu rosto ficasse desfigurado.

Os fatos descritos foram observados atentamente por pessoas que, naquele momento, participavam do protesto organizado pelo movimento estudantil, que congregou mais de 150 mil pessoas no centro de Santiago. Unidades das Forças Especiais, a polícia de choque de Carabineros do Chile, dispersaram a multidão de manifestantes (mascarados e não mascarados) com gases lacrimogêneos e jatos d'água. As cenas de destruição chamaram a atenção de um grande número de fotógrafos que estavam naquele local acompanhando a passeata dos estudantes. A imagem do Cristo sendo desfigurado, lógico, chamou a atenção deles, existindo hoje várias fotografias do instante inesperado. Dentre as várias fotografias que circularam dos eventos acima descritos, uma delas mostra um policial carregando no colo um dos braços mutilados da escultura sagrada. O gesso emulando a pele desnuda do corpo crucificado contrasta com os braços do policial protegido com roupas especiais. A ostentação nos equipamentos usados pela unidade de choque treinada especialmente para reprimir protestos de rua levou os estudantes a darem a esses uniformados o apelido de Robocop, em referência ao popular filme dos anos 198 o protagonizado por um policial cyborg151.

Em Santiago, poderíamos dizer que se deu o improvável encontro entre Robocop e Jesus, o instante cinematográfico decisivo do policial carregando a divindade despedaçada até o templo neogótico da cidade. Pedaços de gesso

${ }^{151}$ Refiro-me ao filme Robocop do diretor Paul Verhoeven, distopia futurista onde o cyborg inventado por uma empresa privada de segurança para policiar Detroit termina desobedecendo os desejos de seus criadores. 
que, no dia seguinte, transformaram-se em evidências criminais custodiadas em laboratórios prontas para e serem analisados por peritos forenses.

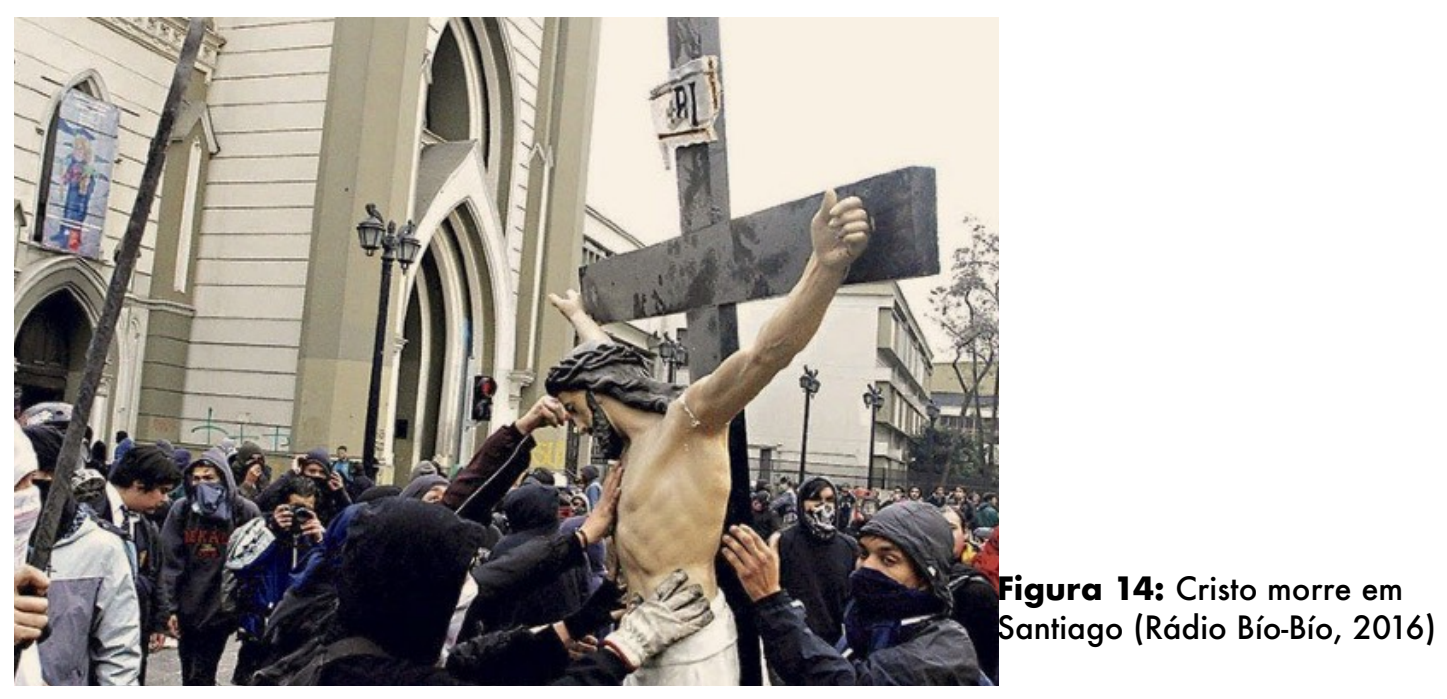

A cena de desfiguração da escultura foi capturada por câmeras de segurança da prefeitura de Santiago, bem como por fotógrafos profissionais e amadores que acompanhavam a passeata estudantil. Imagens do desmembramento de Cristo circularam em jornais, canais de televisão e redes sociais, causando a ira do público. Se os encapuchados já tinham críticos acérrimos, o fato de agora quebrarem figuras santas os transformou em alvo do repúdio geral. A ex-presidenta Michelle Bachelet declarou à imprensa: "Con o sin capucha, la violencia es inaceptable"152. Logo depois, enviou o próprio Ministro do Interior, o democrata cristão Mario Fernández, a visitar a destruída imagem, enquanto um outro membro desse partido, o senador Ignacio Walker, no Twitter, dizia: "Encapuchados matan a Cristo en Santiago"153. Outras autoridades falaram de vandalismo, sacrilégio, atentado, enfatizando cada palavra e, a depender do tom, sugerindo a proteção da propriedade, o sentido religioso do ataque, a potência disruptiva do ato contra a paz social, etc.

152 Fala de Michelle Bachelet, 9 de junho de 2016. Disponível em: shorturl.at/chsvA. Acesso: 05/09/2017

153 Fala do senador Ignacio Walker, 9 de junho de 2016. Disponível em: shorturl.at/mvyFG. Acesso: 06/08/2017 
Ainda que esse tipo de evento não seja o mais comum nas mobilizações estudantis, nos últimos cinco anos, essa igreja e outras localizadas na rota que usualmente seguem as passeatas no centro de Santiago foram alvo de ataques de baixíssima intensidade: pixos e lançamentos de coquetéis molotov ${ }^{154}$. O usual é a destruição seletiva, parcial e reversível de coisas e lugares que, na lógica de seus destrutores, seriam símbolos do Estado e do Capital. Desde 2011, ano das maiores mobilizações vividas em Santiago desde a redemocratização, o quebra-quebra de vitrines de bancos e de McDonalds, o derrubamento de símbolos e a queima de ônibus se repetem Santiago e, em menor escala, em Valparaíso e Concepción.

Fast food, fogo rápido. Em junho de 2004 um grupo de mascarados atirou coquetéis Molotov na lanchonete McDonalds que fica na esquina de Macul com Grecia, dando início a um incêndio que destruiu em menos de uma hora o prédio de três andares. A reconstrução do local foi veloz e, desde então, até hoje, no estacionamento do local, há um camburão da polícia de choque de forma permanente. Naqueles anos, com os protestos alterglobalização pipocando em diferentes cidades do mundo, os ataques a locais de comida rápida não eram raros. Para os anti-capitalistas, o McDonalds e outras empresas semelhantes perpetuavam regimes de exploração laboral, promoviam o maltrato animal e colaboravam para o desmatamento de florestas tropicais. Panfletos encontrados na esquina de Macul com Grecia convocavam para um ato de solidariedade aos presos políticos em greve de fome no Cárcel de Alta Seguridad (CAS), que exigiam o acesso a benefícios carcerários. Um pouco antes do incêndio, Jorge Correa Sutil, advogado e exsecretário da Comissão da Verdade e Reconciliação, naquela época, subsecretario do Ministério do Interior no governo do ex-presidente, o socialista Ricardo Lagos, declarou à imprensa: "queremos dejar en claro que ni

\footnotetext{
$154 \mathrm{Na}$ história chilena, não há ataques iconoclastas da magnitude dos vividos, por exemplo, na Guerra Civil espanhola. Contudo, na década de 1980, grupos de esquerda armada atacaram templos mórmons em Santiago sob a justificativa de que seriam uma das formas do governo estadunidense de se instalar nas periferias populares da cidade e, desde de lá, exercer controle territorial e político. Tal tipo de ação tem se repetido nos últimos anos, associada, ainda, a discursos anti norte-americanos, conforme dito em panfletos achado no local atacado.
} 
las piedras ni las bombas molotov son argumentos en democracia” 155. Naquele ano, mais um McDonald foi destruído nos protestos de novembro contra o Foro de Cooperação Ásia Pacífico (APEC), sediado em Santiago'156.

$\mathrm{Na}$ virada dos anos 2000, a quebra desses estabelecimentos destacouse em meio aos repertórios de ação encenados nos protestos alterglobalização em Seattle, Praga e Gênova. Naquela época, cientistas sociais comprometidos com os militantes explicavam que esses atos não eram, apesar dos ditos pela imprensa, "simples atos de violência". Eram algo diferente, uma ação direta. Duas décadas depois, a categoria ainda é a preferida entre ativistas e acadêmicos que questionam a lógica liberal da propriedade privada e do Estado de direito. Exemplo é o Direct Action: an ethnography, o vastíssimo livro de David Graeber (2009). O que é ação direta? Práticas de resistências que impugnam o Estado como autoridade maior, recusam a mediação de agentes estatais, exibem um alto conteúdo simbólico e que não ignoram o uso da força física como forma de agir politicamente. Trata-se de ações que infringem parâmetros legais estabelecidos para a atividade política, distanciando-se das passeatas e greves, quase sempre autorizadas pelos corpos de segurança 157. Okupas, sabotagens e destruição de símbolos do Estado e do Capital seriam formas de ações diretas, atividades onde os participantes se organizam para evitar serem presos pela força policial.

155 Não foram as primeiras greves dos presos políticos: desde o 2001 elas se sucediam, contando com apoio no exterior, de organizações de parentes, como também a mediação de Alfonso Baeza, padre da igreja católica, além de mais de 150 intelectuais e acadêmicos que organizaram um abaixo assinado em prol dos presos políticos.

${ }^{156}$ No Brasil, Julia Di Giovanni (2008) trabalhou em sua pesquisa de mestrado, defendida no Programa de Pós-Graduação em Antropologia Social da USP, os protestos contra-globalização em Seattle, Praga e Gênova. Na sua análise, mobilizou os conceitos de performance, liminariedade e ritual de Victor Turner. Como outros autores, ela entendeu a depredação de locais de grifes internacionais e de bancos, como compondo uma "ação direta" contra os símbolos do Capital.

157 É importante notar que a distinção entre ação direta e resistência civil é de ordem analítica. Na prática, as ações de protestos de rua podem ser a mistura de ambos os tipos, enfatiza o autor (Graeber, 2009, p.405). De outro lado, vale dizer que, dentro da categoria ação direta, há autores que diferenciam entre as de tipo violenta e não violenta. 
Graeber dedica várias passagens à controvérsia organizada ao redor da pergunta: a destruição da propriedade pública e privada é ou não uma violência? Os meios de comunicação estiveram obcecados na Europa e nos Estados Unidos com a figura dos Black Blocs, mascarados que parecem não ter outro propósito que não a devastação da cidade. Quem são eles? O que pensam? Qual a sua ideologia? Quais suas demandas políticas? Entre os militantes anti-capitalistas, houve consenso de que a quebra de lojas e bancos não era violência, justamente porque se tratava de uma destruição exercida sobre objetos, não contra seres humanos. A destruição durante as "contrareuniões" do FMI ou do G2o, ironiza Graeber, foi uma das mais agressivas de não-violência ${ }^{158}$.

Em Black Blocs (2014), o cientista político Francis Dupuis-Déri, da Universidade de Montreal, definiu os atos de depredação como "violência performática", quase que um jogo no qual se personifica o "anarquista violento" (Dupuis-Déri, 2014, p. 114). As destruições de baixa intensidade e não letais, mais do que violência, são performances políticas e simbólicas de crítica radical anticapitalista. Mas não só isso. Tanto na análise de Graeber (2009, p. 439), como na elaborada por Dupuis-Déri (2014, p. 116), a destruição parcial de lojas e vitrines tem sido meio para quebrar o feitiço do capitalismo e da sociedade de consumo, destruir a aura sacrossanta dos bens de consumo. Para militantes a favor dessas táticas, tratava-se de expor a verdadeira violência, a sistêmica, a perpetrada por grandes corporações: "Significa uma destruição literal de ilusões. É uma profanação [desecration] do que parece monumental e permanente, a destruição da superfície do Espetáculo" (Graeber, 2009, p. 490).

No breve ensaio Iconoclasm Dictionary (2012), Taussig parte da seguinte constatação: falar de iconoclasmo, hoje, pode ser uma escolha antiquada, quase extemporânea às seculares democracias ocidentais. Se nos bons e velhos tempos a distinção entre o que era e não um ícone era clara afinal, lá estavam os ícones em altares sendo adorados ou espalhados pela

\footnotetext{
${ }^{158}$ Em tal sentido, também argumentou Francis Dupuis-Déri (2014). Aliás, ambos os autores ganharam destaque no Brasil entre acadêmicos e jornalistas que buscavam compreender e não só condenar a irrupção da tática dos "blocos negros" nos protestos de Junho de 2013, sobretudo em São Paulo e no Rio de Janeiro.
} 
cidade, cobertos de excrementos de pássaros - , na atualidade, seria cada vez mais difícil identificá-los. Taussig envereda para uma proposta que pensa os ícones não pela sua natureza divina intrínseca ou pela adoração de seus seguidores, e sim pela potência de sua destruição: os ícones se revelariam no instante da ameaça real ou virtual de seu aniquilamento. Dando andamento ao argumento, Taussig comenta os protestos alter-globalização em Toronto, em 2010, quando a cidade foi anfitriã da reunião do G20. Especificamente, ele reflete sobre o enorme número de agentes policiais destinados a reprimir manifestantes. No policiamento ostensivo, há a demonstração do potencial da violência estatal que pode chegar a ser acionada em caso de alguém ousar transgredir as delimitadas "zonas de segurança”; aí, os ícones se deixam realmente ver: um dia qualquer, sem defesas, sem militares e policias ao redor, as vitrines dos bancos e de grandes corporações não são mais do que vidraças transparentes.

Em Defacement: Public Secrecy and the labor of the Negative (1999), livro publicado, aliás, no momento do auge dos protestos alter-globalización, Taussig parte da destruição iconoclasta: "Quando o corpo humano, a bandeira da nação, o dinheiro ou uma estátua pública é desfigurada, um estranho excedente de energia negativa emana do objeto desfigurado. É agora, no estado de sacrilégio, quando mais perto estamos do sagrado no mundo moderno" (Taussig, 1999, p. 1). Ou seja, é no instante da desfiguração, da libertação desse estranho excedente, que os ícones aparecem com toda a sua força. Pense-se nas seguintes imagens: a queima de bandeiras ou de notas de dinheiro, na decapitação de esculturas, no Cristo desmembrado. Quando derrubadas as estátuas de figuras históricas, agora repudiadas, de certo modo, elas voltam à vida, aparecem e se tornam presentes 159 .

A possibilidade de sacrilégio é, aliás, levada a sério pela lei: no Chile, como no Brasil e em outros países, atacar a bandeira nacional é crime de ultraje, ofensa muito grave, tanto é assim que artistas e ativistas têm sido processados pela Lei de Segurança Interior do Estado, e até pela justiça militar, por ofender os símbolos da pátria. Destruir a bandeira é como se

159 Há algo de perturbador, por exemplo, no Monumento às Bandeiras que certa manhã despontou na frente do Parque Ibirapuera, em São Paulo, coberto de tinta vermelha, em ato anônimo de levante. 
danificasse a Nação, o Estado, o Povo. Estabelece-se, aqui, uma equivalência entre representação e representado, tal como no caso do cristo crucificado: "Cristo ha muerto en Santiago".

A razão pela qual trago, aqui, uma discussão do trabalho de Taussig é de ele incorporar os corpos humanos dentre os alvos dos atos iconoclastas. Como já visto, o termo "ação direta”, deliberadamente, exclui a lesão a seres humanos. Se bem reconheço a importância política dessa estratégia, de desativar a discussão em termos de violência, o conceito de ação direta não me ajuda a compreender a importância da danificação da polícia nos embates analisados nesta tese. Não é sobre a desfiguração desse tipo de corpo, os policiais, no entanto, que Taussig se debruça, mas sim na autoimolação de Mohamed Bouazizi na Tunísia em 4 de janeiro de 2011. Logo depois de suas mercadorias terem sido confiscadas (roubadas) por inspetores municipais, o jovem camelô tunisino lançou fogo sobre o próprio corpo, na frente do prédio do governador de Ben Arous. O instante terrível e espetacular as chamas o transformou em ícone da Primavera Árabe.

Muitos de nós, nas redes sociais, vimos ou ouvimos acerca desse sacrifício político. O seu nome passou a ser cantando nos protestos de rua e sua fotografia erguida em cartazes. Mas por quanto tempo? - pergunta-se Taussig. É verdade que, há 8 anos daquela morte, Mohamed Bouazizi ainda faz parte da memória viva da Tunísia: seu rosto dissemina-se em murais, até em selos postais. Porém, ressoa a pergunta amarga de Taussig: nos recordamos dele, sim, mas até quando?160

Entre os símbolos que representariam o Estado e o Capital, não só há coisas como também corpos, mais especificamente, os corpos-policiais. Em 2 de setembro de 1999, no centro de Santiago, Victor Torres, 43 anos, agente da polícia de choque, ardeu em chamas. Desde a janela desde uma sede

160 No Chile, na ditadura, uma das imagens marcantes da resistência dos corpos frente ao horror do terrorismo de Estado foi um corpo em chamas: em 11 de novembro de 1983 , Sebastián Acevedo, pedreiro e militante comunista, ateou fogo no próprio corpo na praça principal de Concepción, logo depois das autoridades da cidade e a Igreja Católica negaremse a lhe entregar informações acerca do destino de seus filhos, Galo e Maria Candelaria, desaparecidos políticos: "Quiero que la CNI devuelva a mis hijos... Señor, perdónalos a ellos y también perdóname por este sacrificio”. Depois de sua morte, seus filhos foram libertados e uma das principais organizações contra a tortura levou o nome de Sebastián. 
universitária no centro de Santiago, foi lançado um coquetel Molotov que caiu sobre a cabeça do uniformado; em instantes, as chamas o abraçaram, o que resultou em $10 \%$ do corpo queimado. $O$ momento exato da imolação involuntária foi fotografado por Christian Castro, que naquele ano ganhou com essa captura um dos mais importantes concursos chilenos de fotojornalismo.

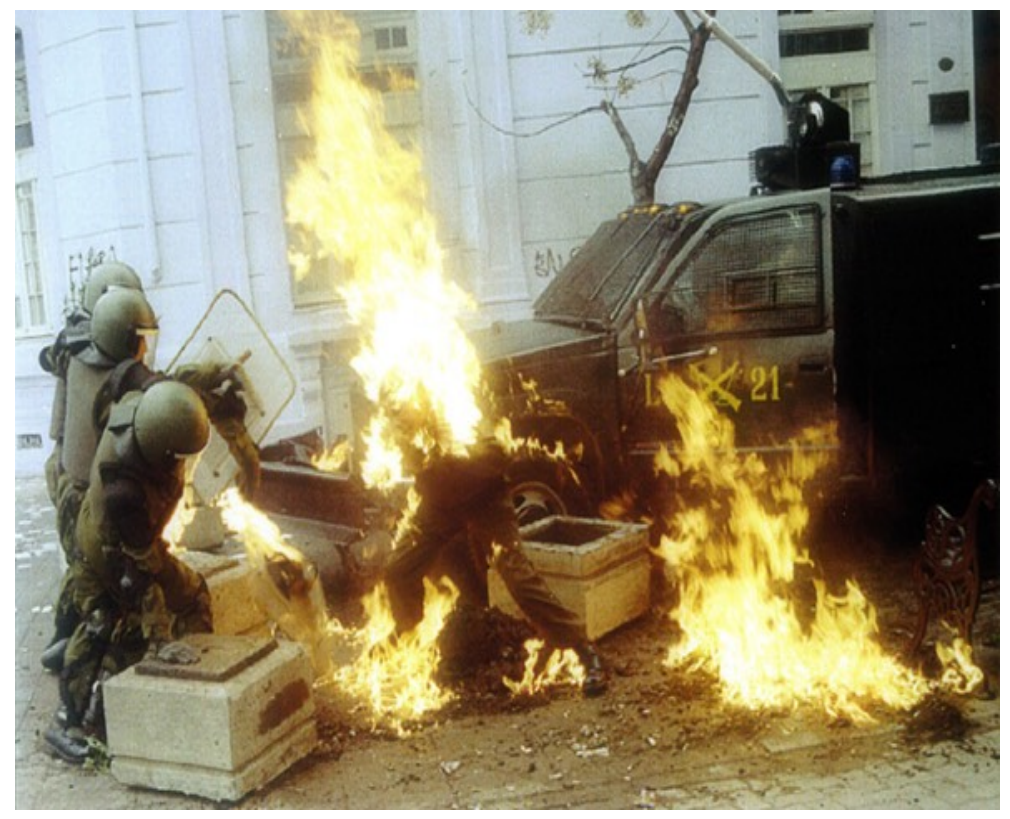

Figura 15: Policial em chamas (Christian Castro, 1999)

No centro da fotografia, vemos a silhueta do homem em chamas. No lado esquerdo, três policiais vestem o equipamento de segurança, cassetete, escudos, coletes, botas, e olham Victor Torres arder. Um deles, parece perder o equilíbrio. No segundo plano, há uma viatura policial, carro de onde teria descido Torres para remover um grande vaso de concreto que encapuchados haviam colocado para interromper o tráfego. No dia, vários jovens mascarados ergueram barricadas na espera de enfrentar a polícia e, com efeito, recordar Claudia López, baleada por forças policiais um ano antes. Ou, pelo menos, assim é reconstruída a história no livro Macul con Grecia, onde o ataque não só é lembrado como celebrado: "Imposible olvidar los gritos de algarabía que retumbaban entre los edificios de la calle Huérfanos al momento del impacto. !Por fin! Un paco en llamas” (Anônimo, 2007, p. 57).

O espetáculo do simbolismo é gritante. Um policial em chamas atacado por encapuchados em memória de uma manifestante morta pela polícia quando mascarada. A relação entre ambos os eventos faz pensar na 
ambivalência entre o desejo de destruição e a necessidade de preservação da memória desses mortos. Em contra-ataque, a polícia ingressou no recinto estudantil: 13 jovens foram presos, alguns levados à justiça militar, outros, à justiça civil. Ninguém foi condenado. As imagens da imolação circularam na mesma velocidade que as declarações públicas de repúdio. Nada podia justificar a queima de um ser humano.

No Brasil, a cientista política Esther Solano (2014) refletiu sobre o ataque a policiais enquanto tática dos "blocos negros" nas mobilizações em São Paulo, em 2013. Sobre a violência concreta contra os homens fardados e as palavras de ódio dirigidas a eles, alertava que tais práticas a faziam duvidar da pertinência da ideia de violência simbólica ou violência teatral na chave da ação direta que circulou no mundo acadêmico e militante para compreender o que a imprensa chamava de "baderna". Em vez de simbólica, se tratava de uma violência muito concreta, que se explicaria por uma dinâmica de desumanização: "Não existe o policial individual. Ele é a corporação, e esta produz um sentimento coletivo de repulsa, de aversão indiscutível”. Na análise de Solano, é a ausência de autoridades do governo nos protestos um dos fatores que explicaria o deslocamento da indignação dos manifestantes para os policiais, os únicos representantes do poder nas ruas. "Porcos fardados", "PM fascista", "PM assassina” - entre outras frases que faziam parte do que ela chamou de "polifonia contra o inimigo".

Os discursos de ódio entre os jovens com respeito à polícia, no entender de Solano, teria relação com a percepção da corporação como instituição inerentemente violenta no cotidiano e, mais ainda, letal. De tal forma, no instante de se agredir um policial, se atingiria a corporação. Para ela, a propagação de tal ódio à polícia era mais do que preocupante: nada podia justificar a comemoração online do ataque a um coronel da polícia em ato contra o aumento da tarifa de ônibus em São Paulo, em 25 de outubro de 2013. Ele merecia, por ser parte da polícia assassina - argumentaram internautas. Tal incapacidade de reconhecer a dor de um homem enquanto indivíduo e a disseminação de discursos de ódio se inserem na constituição de uma dialética de guerra contra o Estado, aponta Solano. A letalidade policial é evidência certa da continuidade, no entender de seus interlocutores, entre a ditadura e a democracia - são seus resquícios institucionais. Em ambos os regimes, a polícia mata para defender interesses do Estado e do 
Capital. Para ela e os outros dois autores de Mascarados; a verdadeira história dos adeptos da tática black bloc ${ }^{161}$, os estigmas reproduzidos do lado dos manifestantes sobre os policiais militares eram tão perigosos como os preconceitos dos policiais sobre manifestantes mascarados. Tal maniqueísmo estaria, simplesmente, impedindo a possibilidade de encontro e diálogo: "Estamos diante de uma espiral de violência, uma dialética de ação-reação entre PM e 'black bloc'. É urgente sair dos estigmas manifestante-vândalos contra PM-violenta" (Solano et al,, 2014, s/p).

Ainda que concorde em parte com a preocupação da autora de buscar outros conceitos para compreender as dinâmicas de confronto entre manifestantes e polícia, no sentido de ser algo que é desejado, procurado e justificado pelos primeiros em discursos, símbolos e práticas, me parece que tal preocupação com a possibilidade de diálogo e entendimentos entre ambas as partes pode ser algo imaginado na chave do ideal habermasiano de encontro racional e dialógico no dito espaço público, juntamente com uma suposta capacidade de negociar e conciliar os interesses via comunicação passiva. Por certo, o que Solano chama de desumanização é uma dinâmica presente também no Chile. Contudo, em vez de falar de estigmas e preconceitos, me pareceria mais pertinente pensar na indistinção entre indivíduo e instituição, no caso dos policiais, como evidência de um processo de iconizacão que não gera adesão nem adoração, mas, ao contrário disso, o ódio.

161 O livro Mascarados foi publicado um ano depois dos protestos no Brasil, ganhando a atenção da imprensa e de canais de televisão; por isso, acabou sendo uma grande campanha de marketing promovida pela editora Geração. Gostaria, contudo, de apontar para um detalhe. Desde sua publicação, chamou-me a atenção o desenho sensacionalista da capa: um jovem negro aparecia com o rosto semi-coberto com uma camiseta olhando de frente para a câmera, de olhos levemente vermelhos. A fonte tipográfica do título, ainda, incluía um símbolo do anarquismo, o "A" em um círculo. Em 2017, tive a oportunidade de consultar Ester Solano acerca dessa capa, em aula da professora Rosana Pinheiro-Machado, na FFLCH-USP, e ela me contou que o jovem mascarado era um trabalhador da editora que foi especialmente mascarado para a fotografia. Por que um jovem negro? Por que os olhos vermelhos? Como isso poderia ajudar, tal como parecia a preocupação dos autores do livro, a desmontar os preconceitos que, naquela época, já circulavam a respeito dos adeptos, como diziam eles, da tática dos "blocos negros"? 


\section{Entre ficções}

Os mascarados disseminam-se não só pelas ruas de Santiago. Nos últimos anos, vários artistas têm colocado no centro de suas criações essas figuras anônimas. No que se segue, debruço-me sobre uma peça teatral, uma série televisiva e duas exposições artísticas. Essas produções têm em comum o fato de inspirarem-se na conjuntura política chilena, em eventos que, de uma forma ou de outra, envolvem aos encapuchados.

Sem ter como finalidade dizer se tais obras são ou não peças de arte política, ativismo artístico ou espetacularização do conflito, interessam-me mais as imbricações entre o factual e o ficcional que cada um desses registros coloca. É por meio dessas considerações que antecipo questões que serão aprofundadas no próximo capítulo: fantasias, desejos e ficções atuantes na persecução criminal da dita violência antissistema e dos mascarados anarquistas.

\section{Mateluna: linhagens imaginadas}

Às vezes, na aritmética jurídica, a prisão perpétua parece ser tempo insuficiente para repor o bem jurídico danificado, como se uma vida fosse, simplesmente, escassa. Na década de 2000, a justiça chilena condenou militares que atuaram no regime pinochetista por crimes de sequestro, tortura e violação dos direitos humanos. Entre eles, atingiu notoriedade o caso de Manuel Contreras, uma das personagens mais nefastas da história do país.

O ex-chefe da Direção de Inteligência Nacional (DINA), a polícia política do regime ditatorial, recebeu várias sentenças perpétuas que, em 
total, chegaram a somar a impressionante cifra de 500 anos de prisão ${ }^{162}$, condenação que o militar cumpriu em um presídio especial, Punta Peuco, para presos como ele, inaugurado em 1995 pelo governo do democrata cristão Eduardo Frei (1994-2000). Nesse local, sem superlotação e com comodidades inexistentes em cárceres comuns, Contreras morreu em 2015, com 86 anos de idade ${ }^{163}$.

No outro lado da trincheira, nos inícios da redemocratização, Jorge Mateluna, com 18 anos de idade, também foi condenado à prisão perpétua. Depois de cumprir condenação entre 1992 e 1994 na Penitenciária Pública de Santiago, foi trasladado para a novíssima Penitenciária de Segurança Máxima (CAS), presídio desenhado nos tempos de democracia para o isolamento político e moral dos "terroristas de extrema esquerda". Foi aos 12 anos de idade que Jorge Mateluna iniciou sua militância nas Juventudes Comunistas, em 1986, ano de protestos populares, mobilizações estudantis e do falido atentado da FPMR contra Pinochet. Dois anos depois, como tantos outros jovens de bairros populares, não acreditou na abertura democrática do regime pinochetista, tampouco no Plebiscito Nacional de 1988. No entanto, em vez de participar nas eleições, o adolescente de 14 anos incorporou-se à FPMR ${ }^{164}$.

Em 1992, foi condenado pela Lei Antiterrorista junto com companheiros de militância, acusados de terem acometido 17 assaltos (ou, como diziam, recuperaciones), 12 atentados explosivos (ou ataques a símbolos do Capital e do Estado) e o homicídio de um segurança de um

162 A DINA atuou como polícia política secreta do regime pinochetista e operou entre os anos de 1973 e 1977; depois, foi substituída pela Central Nacional de Informações (CNI), que deu término a suas atividades apenas em 1990. Vale dizer que, embora 500 anos seja bastante coisa, se falamos de condenações longas, esta parece até breve quando comparada com sentenças na Espanha. Naquele país, os condenados pelo ataque terrorista de $11 \mathrm{M}$, por exemplo, receberam mais de 40.000 anos de sentença; integrantes da Pátria Basca e Liberdade (ETA), por sua vez, mais de 3.000 anos, como o caso de Inés del Río Prada - que, finalmente, a mando do Tribunal Europeu dos Direitos Humanos, foi liberada em 2013, após 26 anos de encarceramento.

163 Sobre Punta Peuco, discorro nos anexos da tese.

164 "Mateluna: La historia del ex-frentista que inspiró la obra de Guillermo Calderón”, reportagem da edição de 3 de junho de 2017 da Revista The Clinic. Matéria disponível em: shorturl.at/uKMY4. Acessado em: 21/03/2019. 
supermercado de Santiago. No decorrer de 13 anos de encarceramento, ele e outros presos políticos organizaram múltiplas ações para exigir a sua libertação, em razão das irregularidades nas prisões e nas penas excessivas. Após anos de luta, que incluíram longas greves de fome que colocaram Jorge em risco de vida mais de uma vez, finalmente, receberam em 2004 o indultado do ex-presidente, o socialista Ricardo Lagos (Rosas, 2013)165.

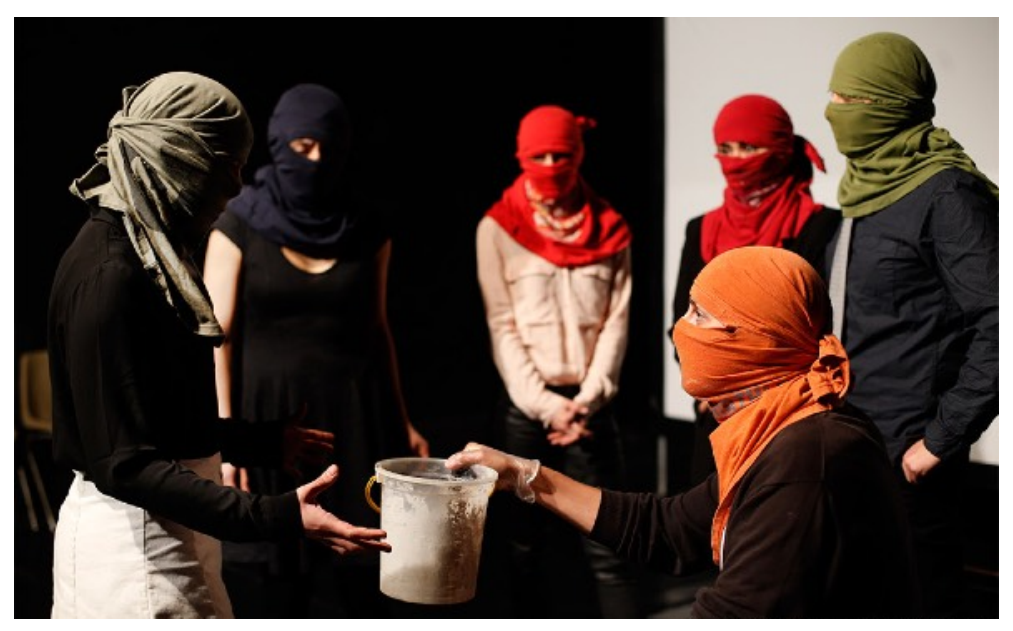

Figura 16:

"Mateluna" (Felipe Fredes, 2016)

Mais de dez anos depois, em 2017, estreou-se Mateluna, uma peça teatral dirigida pelo dramaturgo chileno Guillermo Calderón ${ }^{166}$. A obra tratou do regresso tardio de Jorge Mateluna à prisão, depois de ser injustamente acusado de assalto a banco. A história é verídica: em 27 de junho de 2013, foi preso pela polícia em um bairro periférico de Santiago, quando estava a caminho de uma reunião de trabalho. A poucas quadras dali, antes de ser abordado pelas forças de segurança, um grupo de homens com seus rostos cobertos assaltou uma agência bancária, fugindo com mais de 80.0oo dólares. A polícia, ao revistar os documentos de Mateluna e verificar seus

165 Para ter acesso ao ato de clemência do poder público, exigia-se dos presos subversivos manifestar, por meio de documento escrito redigido ao Ministério de Justiça, o "compromisso inequívoco de renúncia do uso da violência” (Lei $\mathrm{N}^{\circ}{ }_{19.965}$, Art.2). Podiam ser beneficiados aqueles condenados por associação terrorista e atentados contra a lei de segurança interior do Estado, por crimes cometidos entre 1989 e 1998. Os indultados eram proibidos de sair do Chile e precisavam reportar-se, periodicamente, na Gendarmería de Chile durante os primeiros cinco anos.

166 No Brasil, a peça foi estreada em São Paulo em 2017 e comentada por Edson Teles no blog da Boi Tempo. Disponível em: https://bit.ly/2CLZaAS. Acessado em: 01/o9/2019. 
antecedentes criminais, transformou ele em suspeito, colocando-o em prisão provisória. Em poucos meses, com base nos depoimentos de uma só testemunha ocular, foi condenado a 16 anos de prisão. Até o dia de hoje, desde a prisão, Jorge insiste na sua inocência.

Em Mateluna, o palco é ocupado por "cabeças de camiseta" das mais diferentes cores: laranja, preto, vermelho, azul, verde. Os jovens atores e atrizes permanecem com os rostos ocultos na maior parte do espetáculo. Ainda que a obra trate do caso jurídico de Jorge Mateluna, ela acaba excedendo o tom testemunhal: situa-se em uma região de indistinção entre história recente e ficção. Para tanto, o diretor faz uso de materiais diversos, intercalando, no palco, atuação, músicas, arquivos fotográficos, registros audiovisuais, notas de imprensa e televisão, alguns desses materiais retirados do próprio dossiê do inquérito policial. Entre estes, há um vídeo filmado pela polícia, procedimento quando uma das testemunhas do assalto diz reconhecer Mateluna. Esta é a prova que fundamentou sua condenação. No entanto, de acordo com a defesa do ex-combatente, houve erros na execução do reconhecimento: a testemunha teria apontado com o dedo para outra pessoa, e não para Mateluna. No cerne dessa peça teatral, coloca-se a pergunta acerca do estatuto das evidências criminais e a construção da verdade, os modos em que o passado de um homem o pode marcar por toda a vida. É assim que a palavra de Mateluna é desacreditada por ser o depoimento de quem, no tempo pretérito, tomou as armas para desafiar a impunidade dos poderosos e as injustiças da ordem vigente. De tal forma, a peça é concebida como recurso tático para dar visibilidade à injustiça sofrida por Jorge.

A companhia teatral conheceu Mateluna em 2013167. Naquele ano, estrearam Escuela, peça que visava dar visibilidade às experiências de jovens que, na virada da redemocratização, participaram da luta armada - memórias

\footnotetext{
167 Recursos meta-reflexivos como este, de fazer referência ao processo de criação da peça, são bastante utilizados no teatro de Calderón. Vale notar, também, que o dramaturgo, no roteiro, confere às personagens os nomes dos atores de sua própria companhia. Assim sendo, a personagem "Jorge", por exemplo, é identificada como "Carlos" no texto.
} 
obliteradas pelas políticas da memória transicional hegemônica ${ }^{168}$. Assim, Jorge participou como interlocutor da companhia, compartilhando a vivência e os aprendizados de seus anos como combatente e como prisioneiro na democracia:

FRANCISCA: Jorge começou a militar aos treze anos, para derrotar a ditadura. E depois continuou lutando. Até que foi preso. Preso na democracia. A democracia na qual Pinochet continuava como Comandante em Chefe das Forças Armadas. A mesma que aplicou a Lei Antiterrorista aos ex-combatentes. Como Jorge. Condenado à prisão perpétua no ano de 1992. E indultado, depois de 12 anos de cadeia. Dos 18 aos 30. Preso. Não estudou na universidade. Não participou de festas imorais. Não foi para a praia com os amigos. Esteve em uma cela. Preso. (Calderón, 2017, tradução minha).

Em Mateluna, os atores confessam que, ao saber do encarceramento de Jorge, duvidaram de sua inocência. Decepcionados, perguntavam-se: por que alguém se arriscaria a perder tudo e a participar de uma recuperación depois de ter passado tantos anos na prisão? Para tentar entender essa possibilidade - a de Jorge ter se transformado em uma espécie de soldado perdido de uma guerra que nunca aconteceu -, criam a peça Vaca169. Nela, imaginam a relação de Mateluna, o ex-combatente, com a violência na atualidade. Mais especificamente, imaginam um Jorge fictício vinculado a um grupo de jovens anarquistas que colocam bombas (chamadas na peça de vacas e queixos) como repertório de ação política contra o Estado. Em uma das cenas, "Jorge" propõe aos jovens ir além da mera ação propagandística:

CARLOS: Vocês não entendem. Me pedem um queixo de barulho, mas trago para vocês um queixo de guerra. Porque a minha luta segue. Eu quero derrotar um exército. E o que tem? Por que não? E

168 Em Escuela, não por acaso, os atores também aparecem mascarados com camisetas. Acerca dessa indumentária, uma das personagens devaneia: "Yo escondo mi cara porque mi lucha es ilegal/Y tengo miedo de que me metan presa y me maten/ Hay gente que muestra su cara porque no tiene nada que temer/ Yo tengo miedo/ Tengo miedo que me apliquen el genocidio [...] Debajo de esta capucha hay ideas políticas/ Y esas ideas me dan dignidad/ Yo podría estar en el cine. Podría estar enamorada. Podría estar jugando paletas en El Quisco/ Pero estoy aquí, arruinando mi vida". Calderón polemiza narrativas militantes acerca de seus mártires e, por meio de sua peça, abre margem para se pensar em dimensões mais ambíguas e afetivas da luta armada que fogem da imagem estoica do guerrilheiro (Larraín, 2019).

169 Vaca é uma peça fictícia, recriada no interior desta outra, Mateluna. Calderón usa esse recurso em várias outras obras. 
sou de um outro século. Sou um jovem-irmão-companheiro. Vocês sabem o que aconteceu comigo? Meteram preso o meu amigo. E eu fiquei livre. Igual a vocês. Terrível. Então, fui para a praia. Por um final de semana. Fui a coletar frutos do mar. E foi como a máquina do tempo. Quando voltei, não tinha mais poder popular. Não tinha mais partido de vanguarda. Cadê a classe operária? Cadê a juventude rebelde? Comecei a me sentir azul claro e rosa por dentro. Um dia ia andando pela rua vi um okupa. Pintada como uma creche do inferno. Vi bandeiras pretas. Ouvi música violenta. E pensei: o que ocorre com essas crianças? Entrei e cheguei na liberdade. A escola dos professores mortos. A uma festa de aniversário de macacos. Vi vocês. E conversei com esses infantes terríveis, que me disseram que queriam ser violentos contra o Estado. Que estavam já cansados. Que eram macacos. Que andavam procurando um macaco que lhes ensinara a fazer queixos. Eu falei a vocês: poxa como é a vida. Me preparei por anos com uma guerra que nunca foi. Posso lhes ensinar tudo. Sei caçar macacos e comê-los com a mão. Sei dar primeiros socorros. Sei andar na rua com cara de inocente. Sei fazer passaportes de papéis coloridos. Não sei fazer queixos atômicos, mas se me dão um pouco de urânio posso tentar. Vocês me amaram. Trataram-me como se fosse o rei da cocada preta. Colocaram-me nomes falsos e me. convidaram para festas imorais. E eu corri o televisor e coloquei uma mesinha. Nela, comecei a fazer queixos. Queijos de barulho. Para vocês. Nas noites de lua abria a janela e escutava como explodiam lá fora os bancos. Sentia-me útil. Importante. Feliz. Mas, um dia, fiquei pensando e disse: para quê seguir com queixos de barulho? Já nem aparecemos no jornal. Então fiquei terrível. Resolvi transformar essa guerra cagona de vacas de barulho, de agitação e propaganda, em guerra real. Não uma guerra fracassada, lamurienta, alcaeda. Não. Uma guerra revolucionária. Nós, que antes matávamos reis. Matávamos milionários. Agora, o único que sabemos fazer é ameaçar pela internet (Calderón, 2017, grifos meus, tradução minha).

As questões tratadas por Calderón, os possíveis contatos, intermediações e contaminações entre experiências combativas passadas e presentes, ecoam não só na imaginação do dramaturgo. Entre 2005 e 2010, houve em Santiago mais de uma centena de explosões de bombas de pequena potência contra caixa eletrônicos, concessionárias de automóveis, delegacias de polícia, igrejas, escritórios de partidos políticos e, inclusive, dependências do organismo estatal de inteligência (Tamayo, 2012; Cortés, 2013). No geral, os ataques aconteceram de noite, quando baixa a possibilidade de ter transeuntes ou usuários nos locais escolhidos. Em 2014, contudo, esse padrão mudou: de dia, em uma das estações de metrô mais movimentadas em um 
bairro rico de Santiago, estourou uma bomba caseira, escondida em uma lixeira. A bomba feriu a mão de uma trabalhadora.

Esses eventos são o intertexto verídico a partir do qual é escrita o espetáculo Mateluna. Em agosto de 2010, 14 pessoas foram acusadas pelo Ministério Público de constituir uma "associação ilícita terrorista" - e de serem culpados dos bombazos na capital chilena. Nos meios de comunicação, divulgaram-se organogramas confeccionados pela polícia, a partir dos quais foram identificadas as lideranças da quadrilha e diferentes classes de integrantes, desde colocadores de bombas, financiadores e encobridores. A palavra "informal" acrescentada no final foi um termo cunhado pelos promotores públicos, e é o elemento que nos alerta, aqui, acerca das dificuldades que tem a polícia para encaixar na lógica do crime organizado e das vanguardas armadas as atividades dessas novas agrupações anarquistas decentralizadas e horizontais. De tal forma, os procuradores insistiram no julgamento em atribuir ao grupo de acusados uma estrutura piramidal, em cujo topo estão nada menos que dois ex-militantes da JML que passaram a década de 1990 encarcerados junto com Jorge Mateluna no CAS170.

Nas genealogias e redes imaginadas pela polícia, os chefes eram encarregados de "recrutar", "doutrinar", "instruir" e "influir" membros mais novos, além de coordenar a manipulação e a colocação de artefatos explosivos (Sentença "Caso Bombas", Tercer Tribunal Oral en lo Penal de Santiago, 2011, p.6). Depois de meses de audiências, os acusados foram inocentados e absolvidos, após terem passado um ano em detenção provisória. Com esse pano de fundo de encarceramentos de jovens que pretendiam a destruição da ordem motivados por ideologias insurrecionais, em uma das cenas de Mateluna, uma jovem devaneia com um mundo prisional tramado por fios políticos, afetivos e eróticos:

CAMILA. Eu não sei porque, mas todas as minhas amigas foram parar na prisão. Ou estavam presas e logo depois viramos amigas. Eu as vou visitar e elas me falam: amiga, você não sabe o que é um percevejo te chupar o sangue; amiga, você não sabe o que é não

\footnotetext{
170 Refiro-me aos ex-militantes do MJL Rodolfo Retamales Leiva e Pablo Morales Fuhriman, que, como visto no Capítulo 2, foram parte do grupo que iniciou o coletivo anti-carcerário Koletivo Kamina Libre, aquele que escrevia cartas com o "encapuchado" de Macul com Grecia.
} 
conseguir sair a comprar um chiclete, ou um frango com batatinhas; não sabe o que significa para uma anarca estar presa. E a verdade é que eu não sei mesmo. Não sei o que é estar presa. Gostaria de saber. Não sei o que é viver no país das mulheres. E eu gosto de colocar vacas porque eu sei que lá dentro elas ficam sabendo disso pelo jornal. Lá dentro, um queixo vale mais que mil chocolates. Vale mais que mil cigarros chineses. É assim que eu coloco queixos com a esperança de que um belo dia vão me encontrar. Com cheiro à vaca. Com as mãos na vaca. Achamos você, Alejandra. Estávamos de olho em você. In fraganti. E vão me enviar ao tribunal, e eu vou me parar na frente da juíza e vou dizer: senhora juíza, matem-me, se quiser, matem-me. De qualquer jeito, a história me absolverá171. E marichiweu ${ }^{172}$, filha da puta, marichiwei. E depois me mandam para a cadeia e as chiquillas me recebem: a Sonia, a Maria, a Negra, a Karen, a Chica, a Coca, a Silvia, a Tiare, a Rosa, a Mabel, a Tina, a Laura, a Betty. E a Rocío mancando, com o cabelo raspado, punk por natureza. $\mathrm{E}$ as chiquillas me abraçam. E me dão as boas-vindas com bolos e bolachas. E me falam: é nós. Agora, você é uma abelha. E depois me levam para o quarto, me tiram a roupa e me fazem sexo. Suruba. Porque agora sou macaca também (Calderón, 2017, grifos meus, tradução minha).

Mateluna discorre, ainda, sobre as farsas policiais e a fabricação de evidências, algo que vimos no capítulo passado. A companhia de Calderón, por meio dessa peça teatral, somou-se à rede organizada para a defesa de Jorge Mateluna desde diferentes frentes: jurídica, política e artística. Por meio de baixos-assinados e declarações de afamados intelectuais e artistas, denunciavam-se as irregularidades nas evidências criminais produzidas pela polícia para incriminar Mateluna. Apesar de todos as tentativas, o pedido de revisão da condenação enviado para a Corte Suprema foi denegado em janeiro de 2019. "Nada termina com esta sentença. Resistirei esta injustiça com dignidade” - comunicava por escrito Jorge desde a prisão ${ }^{173}$.

\footnotetext{
${ }^{171}$ Aqui, cita a afamada frase de Fidel Castro.

172 Consigna da resistência mapuche, povo indígena no sul do país, que demanda autonomia territorial. A expressão significa “venceremos 10 vezes”.

173 Declarações de Mateluna à imprensa logo depois da sentença da Corte Suprema. Disponível em: https://bit.ly/2lQxjtW. Acesso em: 15/11/2018. Mais informação sobre a campanha "Mateluna inocente", disponível em: http://www.matelunainocente.com.
} 


\section{Lobos e Ovelhas: anarcos na tevê}

"Quando a ideologia explode, o medo nos invade a todos". Durante duas semanas, por meio dessa frase, divulgava-se em um importante canal público o próximo capítulo do show 12 días que estremecieron a Chile. $\mathrm{O}$ programa televisivo recriava acontecimentos marcantes da história recente chilena, desde o terremoto de 2010, a vitória do Chile da Copa América em 2015 e o dia em que morreu Pinochet, em 2006. Dessa vez, o capítulo dirigido por Juan Ignacio Sabatini e intitulado Lobos e Ovelhas trataria da já mencionada explosão acontecida no dia 8 de setembro de 2014 em uma estação de metrô na zona nobre de Santiago. A arrebentação causada pelo artefato de média potência fabricado com pólvora negra e escondido em uma lixeira, como disse, feriu uma trabalhadora que perdeu uma falange de um dedo da mão. Jornais internacionais rapidamente reportaram o evento como atentado terrorista e o Ministério Público, no julgamento de 2017, remarcou que, por meio do terror e do medo, o ataque tinha mudado o Chile e a vida em Santiago (Condenação "Caso Metrô" Sexto Tribunal Oral en lo Penal de Santiago, 2018).

Como é característico do gênero policial, no episódio, vemos duas forças antagônicas em luta. De um lado, o anarquismo insurrecional, encarnado por um grupo de jovens punks. De outro, a ordem pública, que pretende a restauração da paz social representada pelo procurador do Ministério Público, um homem com cerca de 40 anos. Sendo uma história ficcional baseada em fatos reais, a produção usa materiais diversos: arquivos de telejornais, depoimentos de autoridades, falas de testemunhas e jornalistas. O protagonista é um jovem anarquista de roupas pretas, piercings e tatuagens, na sala de um apartamento decorado com pôster da banda Sex Pistols, um cartaz com o símbolo do anarquismo e uma bandeira do povo 
indígena Mapuche174 - ele assiste na tevê notícias do atentado no metrô. Rapidamente, colhe panfletos, fanzines e outros documentos espalhados pela casa e os queima em uma pia ${ }^{175}$. Há, no episódio, uma superposição entre ficção e realidade: nos últimos 10 anos, na justiça chilena, começaram a proliferar como evidências criminais livros sobre anarquismo, fanzines de contracultura, camisetas e discos de punk. Aos olhos da polícia e do Ministério Público, esses objetos seriam superfícies de inscrição ideológica, assunto do qual tratarei no capítulo a seguir.

Por sua vez, o antagonista (ou protagonista, dependerá do critério do telespectador), o promotor do Ministério Público, é apresentado na intimidade da vida familiar, em uma casa de alto padrão, conversando com a filha e a esposa. De improviso, ele recebe uma ligação telefônica; ao ligar a tevê, fica sabendo do jovem anarquista e dos eventos recém acontecidos no metrô. Em seguida, uma voz off masculina, a mente do promotor, se faz ouvir: "Logo que a bomba explodiu todos tínhamos medo. Medo de que esses grupos anarquistas fossem reais, que o terror estivesse logo na esquina, na casa de um vizinho. Medo de que em qualquer minuto, em um dia qualquer, poderia se perder tudo" (LOBOS E OVELHAS, 2017, tradução minha).

Estabelecidas as contrapartes, é encenado o contexto social imaginado para o jovem anarquista: um okupa ${ }^{176}$. Naquele local, jovens desenham um mural onde lobos-anarquistas brigam com porcos-policiais vestidos de

174 As referências aos mapuches têm relação com o ativismo desse povo na defesa de indígenas em circuitos anarquistas. Esses grupos solidarizam-se com a demanda territorial e de autonomia das comunidades que habitam o sul do Chile. Nos últimos dez anos, são várias as lideranças políticas e religiosas dessas comunidades que têm sido acusadas pelo Ministério Público de atividades terroristas, inclusive condenadas pela suposta responsabilidade que lhes caberia em atentados incendiários contra propriedades privadas de empresas florestais e de latifundiários que, ao seu ver, estariam ocupando ilegitimamente terras ancestrais. Os julgamentos são altamente polêmicos, e o Estado chileno, conforme afirmaram ativistas dos direitos humanos, estaria transgredindo convênios internacionais sobre direitos indígenas.

175 Alguns desses documentos políticos decorativos na cena televisiva são, de fato, reais: me refiro, sobretudo, a um conhecido fanzine ácrata chamado El Surco.

176 No Caso Bombas, de 2010, o Ministério Público argumentou que esses locais eram só "fachadas culturais" para disfarçar o que realmente interessava a esses grupos: a organização de atentados. Nesses anos, as ocupações mais emblemáticas de Santiago foram assediadas pela polícia e, finalmente, despejadas. 
cassetetes e capacetes, entre protestos e barricadas. Enquanto os jovens fumam, bebem cerveja e preparam pão artesanal177, o protagonista discute o atentado, desconfiando que seus amigos tivessem sido os perpetradores do ataque: "Olha só, esse cara acha que nós somos os terroristas mais buscados do Chile! Essa merda não é anarquismo, porra! Ou você acha que vou explodir a mão de um operário como o meu pai?”. A cena traz à tona os debates que se multiplicaram em blogs ácratas logo após o ataque do metrô, em 2014. Discutia-se em colunas anônimas e posts os limites na ofensiva contra o Estado e o Capital: podiam ser danificados civis? Qual era o lugar dos cidadãos, aqueles que, por meio de sua obediência e passividade, dão continuidade ao sistema social vigente? No comunicado que circulou na Internet logo após o ataque, lamentava-se o dano à trabalhadora. $\mathrm{O}$ alvo não era ela, mas as "estruturas, propriedades e os esbirros do poder". Seguidamente, o comunicado expressa solidariedade com todos aqueles que, ao redor do mundo, lutam contra a dominação. Em um ato posterior, citam-se nomes de presos políticos no Chile, na Itália e na Grécia, bem como jovens mortos na "guerra social”, como Mauricio Morales. "Ninguém é olvidado", encerra a missiva anônima ${ }^{178}$

No capítulo televisivo, recriam-se discussões entre aqueles promotores da antiga escola que buscam suspeitos e vinculações entre anarquistas e exsubversivos dos anos 1990 com outros, como o promotor-protagonista, que pretende uma investigação imparcial embasada em evidências científicas tais como análises de câmeras de segurança, exames biométricos e coleta de material genético, investigações complementadas com o exame de "fontes

177 Este último detalhe, que poderia parecer mínimo tem a ver como o fato de que, em Santiago, em várias esquinas do centro, nas saídas do metrô, é comum que jovens vendam pão vegano. Juan Flores, aquele que realmente foi condenado no mundo real, dedicava-se a tal atividade de comércio informal de gêneros alimentícios.

178 Vale dizer que, entre as referências e citações que estruturam esse comunicado, cita-se um outro divulgado em 1971, em Londres, assinado por The Angry Brigade, grupo de guerrilha urbana que teria sido responsável pelo ataque explosivo a uma loja de roupas. A frase diz: "A vida está tão chata que não há nada mais a fazer do que gastar o salário comprando a última saia ou camisa da moda? Irmãos e Irmãs, quais são teus desejos reais? Sentar-se em uma cafeteria, olhar sem rumo, vazio, entediado, e beber um café sem sabor? Ou, talvez, O EXPLODIR OU O QUEIMAR? O comunicado chileno está disponível em: https://bit.ly/ 33yfMrZ. Acessado em: 15/06/2018. 
abertas", nomeadamente as redes sociais dos suspeitos. Em uma cena, vemos a promotor acessando o perfil do Facebook de um dos jovens presos, que se torna mais suspeito à medida que o promotor acha em sua página pessoal símbolos do punk, imagens de protestos e de policiais do choque. Como veremos no capítulo seguinte, a atuação da polícia nas redes sociais excede a simples inspeção de conteúdos públicos: aos agentes infiltrados offline, somam-se, agora, os online (Carrasco \& López, 2013).

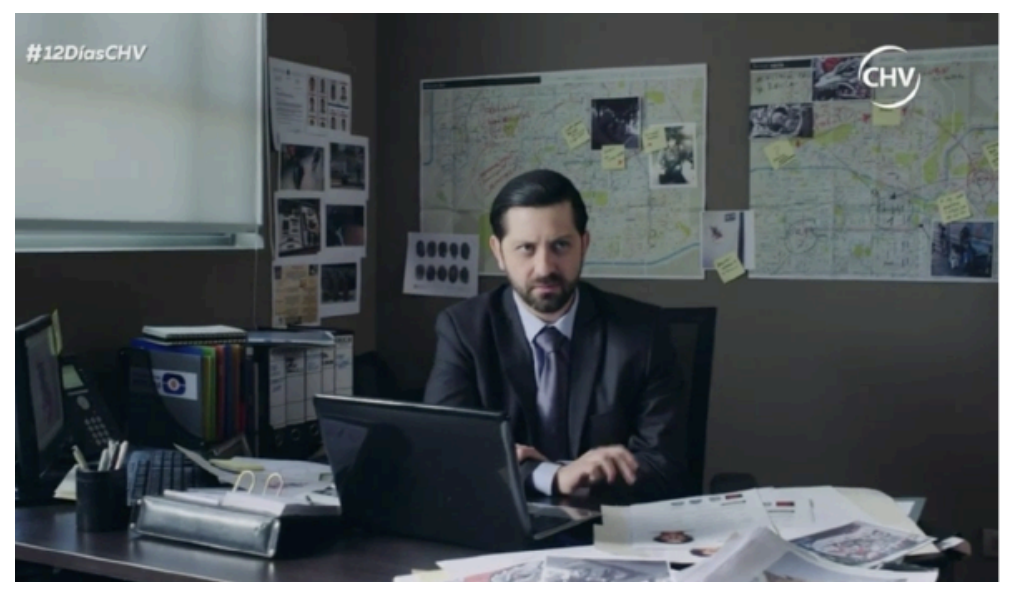

Figura 17: Programa TV "12 Días" (CHV, 2017)

No show, há um ponto de inflexão que torna mais difusa a distinção entre o bem e o mal. O promotor descobre que seus colegas do Ministério Público inventaram provas para vincular um dos suspeitos em prisão provisória com ex-presos "subversivos" dos anos 1990. Ao denunciar o procedimento, ninguém the dá atenção. O que importava, asseveram seus chefes, era que terroristas estivessem presos na cadeia; era isso o que se esperava deles. Ante o dilema moral, o promotor renúncia ao caso: "Às vezes [...] se atua confundindo teorias com fatos. Se pretende resolver um caso com tanta força, que se pode terminar como um inocente na prisão ou com um culpável livre. Eu não posso ser parte disso" - a voz off do promotor ressoa enquanto ele, com expressão taciturna, deixa seu escritório. Do outro lado, o jovem anarquista resolve escrever uma carta delatando quem seriam os verdadeiros culpados, outros jovens punks, de moicanos, vestidos de preto e capuz que aparecem no final do episódio descendo com olhares furtivos as escadas do metrô. 


\section{Encapuchados inexistentes}

A artista chilena Inés Molina, em 2013, exibiu uma série de retratos de homens e mulheres com seus rostos cobertos com camisetas. Ainda que o realismo das fotografias tenha levado os espetadores a acreditarem que se tratava de fotografias de pessoas reais, esses homens e mulheres não existiam (Figura 18). Conforme explicou a própria Molina em uma entrevista179, sua proposta artística inspirou-se na tecnologia de identificação criminal criada no século XIX pelo inglês Francis Galton - os chamados "retratos compostos". O fundador da eugenia moderna, convencido da existência de um subtipo humano criminal, inventou uma técnica para imprimir, por meio de capturas fotográficas superpostas de centos de condenados, a imagem do tipo ideal do criminoso (Pavlich, 2017). Nas palavras do próprio Galton, os "retratos combinados" (composite portraits) não representavam um homem em particular. Ao contrário, tratava-se de uma figura imaginária que possuía traços "promédio" de um grupo qualquer de homens: "Ninguém que olha para eles pela primeira vez pode duvidar que se está olhando diretamente para uma pessoa viva” (Galton, 1989 apud Pavlich, 2017, p. 175).

Apropriando-se de tal princípio (claro que com propósitos diferentes), a artista chilena fotografou traços de diversos homens e mulheres, jovens e adultos, tratando-os como se fossem peças de um puzzle. Por meio da superposição e da montagem, deu vida a rostos inéditos, porém bastante reais. A exposição fotográfica intitulou-se 541 dias, sendo que o nome dizia relação ao tempo de sentença que, no Chile, pretendia se dar aos condenados pela chamada "lei anti-encapuchado", projeto proposto pelo governo de Sebastián Piñera (2010-2014) e que buscava aumentar as penas para os delitos de desordem pública, ataque à polícia, realização de passeatas sem autorização, ocupações de escolas e universidades. Inclusive, e vem daí o apelido, pretendia-se penalizar o uso de panos e prendas no ocultamento do rosto em protestos de rua. Cristián Monckeberg, parlamentário da Renovação Nacional (RN), militante do mesmo partido que Piñera, na época foi bastante ativo nas respostas às críticas dirigidas por congressistas da centro-esquerda.

179 Matéria disponível em: shorturl.at/cv456. Acessado em: 02/04/2016. 
O projeto, a seu ver, "sanciona exclusivamente aos que constroem barricadas, interrompem o trânsito das ruas e cometem crimes com seus rostos cobertos. Então, não incomoda nem criminaliza ninguém"180. O projeto foi finalmente votado e acabou sendo derrubado. Em 2016, voltaria a ser proposta uma nova versão, mas novamente sem sucesso.

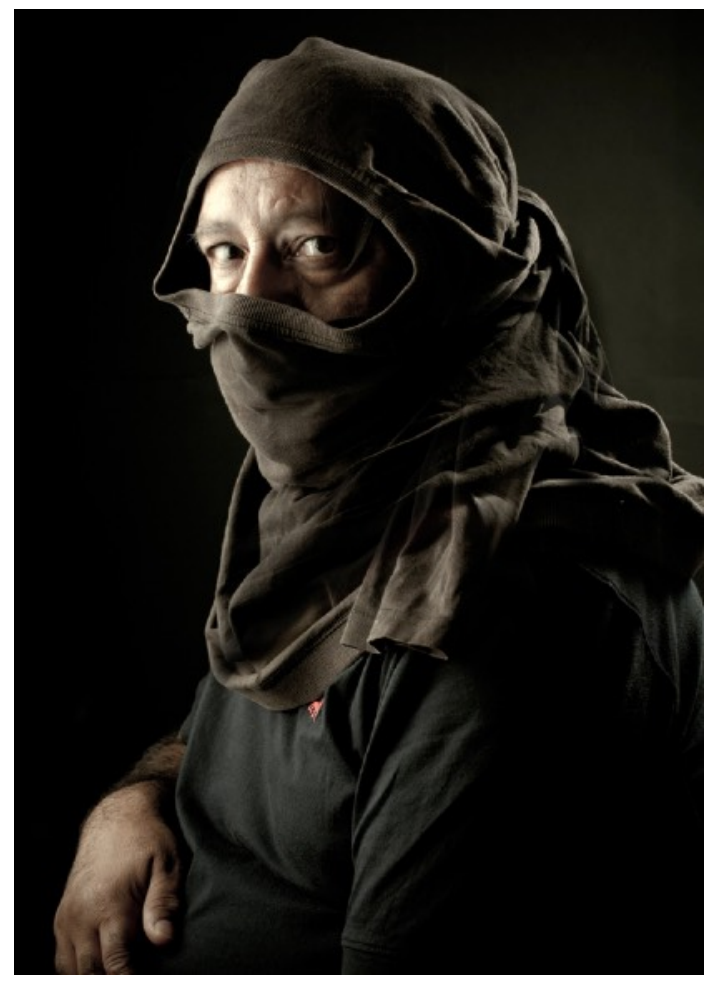

Figura 18: Exposição "541 días", (Inés Molina, 2014)

Outros mascarados falsos apareceram, ainda, em 29 de novembro de 2014, na frente do Museo de Arte Contemporânea (MAC) no parque Quinta Normal em Santiago. Na instalação "El ladrillo angular" do artista Francisco Tapias (apelidado "Papas Fritas")181, aparece uma jovem secundária, de pé, com o rosto coberto com uma camiseta preta, mochila nas costas, unhas

180 Fala disponível no site Radio Universidade do Chile, em: shorturl.at/fgny1. Acessado em: O2/11/2016.

181 "El ladrillo angular", obra de Francisco Tapia, foi parte da exposição "Trabajadores de la Luna”, com curadoria do coletivo Etcétera. Mac Quinta Normal, 29 de novembro 2014 - 18 de janeiro de 2015. É de se notar que o título da performance de Tapia faz referência ao libro "El Ladrillo", programa econômico redigido por economistas chilenos que se formaram na Escola de Chicago nos anos 1970 e que participaram do regime pinochetista. 
pintadas de verde e uma AK47 nas mãos. A figura de gesso de tamanho natural aponta para uma fileira bastante peculiar: um após o outro, descabeçados e caindo de bruços, cada um dos presidentes da pós-ditadura. $\mathrm{Na}$ frente da garota-gesso, nada menos que Augusto Pinochet, com suas roupas militares, que, ferido, sangra pela boca. Performance estática, figuras em suspenso em meio de uma cena violenta, cena de vingança um tanto quanto gore.

Em uma segunda etapa da instalação artística, a estudante de gesso cobra vida. Uma atriz de carne e osso, vestida similarmente à escultura, de uniforme e também mascarada, apareceu em 11 de dezembro de 2014 nesse mesmo local: "eu sou Elizabeth Díaz"182 - declamou aos espetadores. Elizabeth foi uma estudante de 14 anos assassinada pela polícia, no dia 13 de outubro de 1973. Ela estava grávida no momento em que foi sequestrada na periferia sul de Santiago, junto com outros 13 jovens que participavam de uma festa em um bairro popular da cidade, jovens sem militância conhecida em seus históricos. Foram baleados com tiros nas costas disparados pela polícia nas beiras do Rio Mapocho. Em 2007, o policial Rubén Barría Igor foi sentenciado a 16 anos de prisão pelo massacre, e o Estado teve que pagar reparações econômicas às famílias dos mortos ${ }^{183}$.

Na performance, o corpo mascarado da jovem atriz, encarnando a ausência fantasmagórica de Elizabeth décadas depois, exclama: "Yo los mato por justicia”, enquanto o público a seu redor aponta pistolas de brinquedo. $\mathrm{O}$ ato final, uma mistura de carne e gesso, é arrebatadora: a secundarista encharca de gasolina uma réplica em escala humana da esposa de Pinochet, a ainda viva Lucia Hiriart. No ato performático, uma espécie de catarse coletiva, a figura é envolta em chamas. O fogo como justiça?

\footnotetext{
182 Elizabeth 14 - Un acto de justicia popular", de Francisco Tapia. Mac Quinta Normal, 11 de diciembre 2014. Santiago.

183 As vítimas fatais foram Alfredo Moreno Mena (23 anos), Luis Rodriguez Arancibia (23 anos), Luis Verdejo Contreras (26 anos), Jaime Bastias Martinez (17 anos), Luis Suazo Suazo (20 anos), Domingo Morales Diaz (2O anos) e Luis Toro Veloso (2O anos).
} 


\section{CAPÍtULO 3}

\section{Presxs a la kalle}

Os nós sempre estão no cerne das coisas, enquanto seus extremos ficam soltos procurando linhas com as quais amarrar-se.

Tim Ingold.

\section{A aranha e o mandala}

Como contabilizar a passagem do tempo para além dos relógios e calendários? Como fazer o tempo correr mais rápido? Nos dois anos que Adriana esteve em prisão provisória, aprendeu, entre outras coisas, a fazer objetos com miçangas. Amarrando fios de náilon, ela deu vida a pequenas criaturas, como a aranha dourada de olhos pretos que ganhei em uma das tantas visitas à cadeia que fiz à cadeia. Para passar o tempo, para viver seus 20, 21 e 22 anos enclausurada, Adriana entrelaçava também fios coloridos, formando círculos concêntricos, as chamadas mandalas, diagramas da cultura budista muito populares, que funcionam como mecanismo para acalmar o “espírito”.

A mandala que Adriana me presenteou é de cores vibrantes: rosa, azul e amarelo. Carreguei ambos, a aranha e a mandala, durante todos estes anos de doutoramento, em cada uma de minhas viagens entre Santiago e São Paulo. Por meio desses fios e nós, sentia que me aproximava dela mesmo à distância; ao contemplar esses objetos tão singelos, ficava comovida à medida que a imaginava tecendo-os com as suas mãos pálidas pela falta de sol nesse lugar que, às vezes, chamava de quarto, para rapidamente se corrigir e dizer: não, é uma cela. Lugar onde compartilhou com mulheres que iam embora, absolvidas ou condenadas, enquanto ela seguia à espera do julgamento, que foi adiado sob as mais diversas justificativas pelo Ministério Público durante dois anos. Os pequenos presentes que saíram de suas mãos para viajarem 
comigo a tão diversos locais são artesanatos marcados de forma indelével pelo espaço onde foram tecidos, memorabília prisional, objetos-testemunhas da capacidade de continuar tecendo nós, de tecer vida mesmo no confinamento. A aranha e a mandala são tramas de solidão e de afetos, assim como fios consanguíneos.

Como já se sabe, Adriana não foi só interlocutora de pesquisa. Em junho de 2015, ano em que iniciei o doutorado, ela, filha do meu tio materno, portanto minha prima, foi acusada de atentando incendiário contra uma delegacia da polícia e, consequentemente, enviada à prisão provisória. Como discuti em detalhe na introdução desta tese, esse acontecimento funesto possibilitou duas coisas: que eu entrasse na prisão como visita de presa e que eu participasse como público no julgamento contra ela e outros quatro jovens ${ }^{184}$. Que pesquisadores entrem na prisão para entrevistar imputados por ataques desse tipo é, simplesmente, impossível: os suspeitos de crimes contra a propriedade pública e privada, incitados, supostamente, por ideologias anarquistas insurrecionais, são classificados como réus "de alto risco". Pela mesma razão, somente duas pessoas, obrigatoriamente, parentes ou amigos, éramos permitidos de acompanhar cada um dos jovens nas audiências. Pelo improvável vínculo de parentesco entre uma pesquisadora interessada na persecução criminal do anarquismo e uma jovem acusada de atacar a polícia por motivos ideológicos, é que este capítulo existe tal como é.

Presxs a la Kalle trata da persecução criminal de jovens acusados de destruir símbolos do Estado e do Capital mobilizados por ideologias anarquistas insurrecionais. Para tanto, utilizei-me do material que coletei em trabalho de campo na prisão de São Miguel e no Centro de Justiça de Santiago, bem como de entrevistas que conduzi com jovens que foram acusados de violência antissistema que também passaram meses em prisão provisória. Documentos judiciais e policiais, bem como textos militantes, complementam o meu corpus empírico.

\footnotetext{
${ }_{184}$ Para quem tiver interesse em saber um pouco mais sobre o sistema carcerário chileno, nas aberturas/fechamentos dos corpos de parentes e amigos em visitação de presos, nos anexos, elaboro uma análise com detalhe sobre a minha experiência como visitante de Adriana (Anexos 1: Notas da prisão).
} 
Neste capítulo, percorro três assuntos. Primeiramente, exploro os modos pelos quais os jovens reelaboram suas experiências carcerárias nos meandros das "memórias combativas", nas tensões e ambiguidades no processo de autoidentificação enquanto presos políticos do século XXI. Depois, examino os regimes de segregação e de tratamento desses suspeitos, que fazem com que o discurso oficial, mesmo negando qualquer sentido político especial, na prática, mobilize dispositivos diferenciados aos dos presos por delitos comuns - fronteiras, por certo, flutuantes. Por último, perscruto as diversas tecnologias usadas na produção de evidências criminais contra os ditos anarquistas, desde o confisco de livros e panfletos, persecuções encobertas, até tecnologias mais modernas, como a identificação de ADN, a geolocalização via telefone celular e o policiamento das redes sociais. Argumento que esse arranjo leva a uma produção de saberes acerca desse novo inimigo interno sobre o qual se debruçam desde peritos de bioquímica até pesquisadores das ciências humanas, sempre com o objetivo de tornar seus inimigos internos visíveis e cognoscíveis.

\section{A memória do fogo}

"Fogo na prisão! As barras [barrotes] não poderão encerrar nossxs ideias e konvicções. Até destruir o últimx bastião da sociedade carcerária!”. Me deparei com essa frase no primeiro dia de visitação a Adriana na prisão de São Miguel, no verão de 2016. Em letras pretas, com erros ortográficos intencionados e, inclusive, os "As" substituídos pelo símbolo do anarquismo, a mensagem fazia parte das inúmeras consignas escritas em um grande muro situado na frente do recinto penitenciário ${ }^{185}$. Nessa parede, dão-se encontro, um acima dos outros, grafites, murais e mensagens dedicados a jovens presos por ataques explosivos e expropriações, bem como consignas à memória de jovens mortos em lutas callejeras (de rua) na pós-ditadura chilena. Trata-se de um lugar, poderíamos dizer, de uma memória obstinada: de tempos em

185 Coincidência curiosa, pois, nessa mesma parede, percebi uma pequena placa com o nome Madeco, umas das mais importantes indústrias de processamento de cobre em Santiago do século XX. Conforme averiguei depois, nesse local, no Golpe de Estado de 1973, organizou-se uma das poucas frentes operárias que tentou resistir de forma armada à empreitada golpista. Mas, como sabemos, ela não logro sucesso e, como militantes do Partido Socialista que se organizaram, seus membros foram assassinados burtalmente (Garcés, 2005; Ascanio, 2013). 
tempos, a prefeitura mandava pintar de branco a parede; no entanto, os slogans anticarcerários e anticapitalistas não tardavam em voltar a se proliferar. As mensagens, ainda, continuariam a parecer em outras superfícies nas redondezas a prisão.

Esse dia, uma vez terminada a visitação e já a caminho da estação do metrô mais próxima, entre lixos e entulhos, reparei em um papel jogado no chão. Nele, apareciam cinco encapuchados desenhados em traços grossos erguendo uma barricada. Do lado da imagem, a frase: "Solidaridade ativa e insurrecta com lxs presxs da guerra social: presxs a la kalle!!!” - seguida, para minha surpresa, do nome de Adriana e dos outros quatro jovens acusados pela mesma causa judicial. No anverso do panfleto, havia palavras em homenagem a Claudia López, a anarquista e dançarina assassinada pela polícia na noite de 11 de setembro de 1998, cuja história revistei no Capítulo 2. A pequena folha voadora, bem como o grande mural, eram ambos, exercícios anônimos de memória, de diálogo entre vivos e mortos, entre presos e mascarados, materialidades e narrativas de um devir combativo.

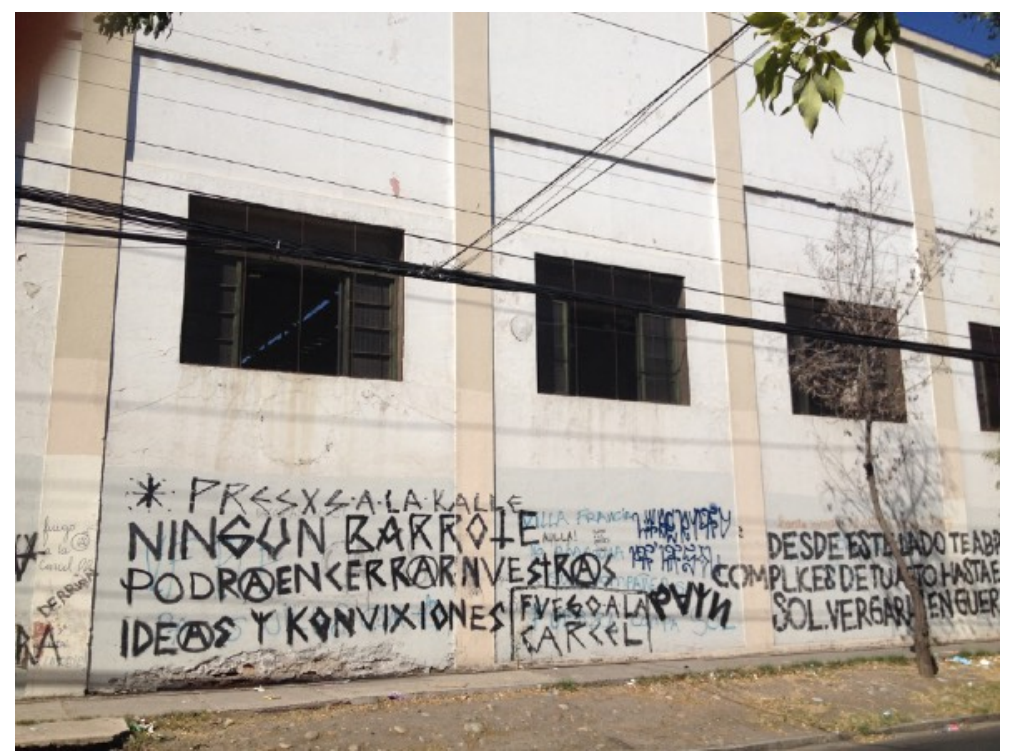

Figura 19: Muro Memória em São Miguel (Foto da autora, 2016) 
A prisão de São Miguel, apesar da aparência monolítica, não é uma estrutura estática. Sem ser muito antiga, a penitenciária já passou por importantes reconversões ${ }^{186}$. Desenhada para uma lotação de 500 presos homens, ela foi erguida em 1982, na comuna de São Miguel, com caráter residencial e industrial - conhecida como a "comuna roja" de Santiago em função das preferências políticas de eleitorado da área (Winn, 2004). Sua primeira mudança aconteceria no ano seguinte, em 1983, com a chegada de um grupo de 15 presas políticas, passando a ser um improvisado recinto carcerário misto. As militantes de esquerda, algumas delas universitárias, assim como Adriana, foram trasladadas até esse lugar como castigo aos protestos organizados no Centro de Orientação Feminino (COF)187. Nesse novo recinto despreparado para receber internas mulheres, as presas políticas sofreram o distanciamento dos filhos (pela falta de creches), bem como a sensação permanente de vulnerabilidade: o que seria delas se houvesse um motim em uma prisão com centenas de presos comuns? (Berenguer, 2000). Depois de vários protestos organizados dentro e fora da prisão, com apoio de

\footnotetext{
186 A prisão do São Miguel foi inaugurado em dia 6 de setembro de 1982 como parte do Programa de Construcción de Establecimientos Carcelarios do Ministério de Justiça, evento que foi presidido pelo mesmíssimo general Augusto Pinochet (González, 2016). Revisando a documentação da época, constatei que, em 1981, período de forte recessão econômica, com uma taxa de desemprego acima do 20\%, construíram-se no país mais de $50.000 \mathrm{~m} 2$ de recintos prisionais, cifra inédita e que iria ser superada só anos depois, em 1996. Em 1982, ainda, inaugurou-se o Centro de Detención Puente Alto. Área rural no sul de Santiago, de baixo valor imobiliário e escassa estrutura de serviço, para os planejadores urbanos da época, foi local ideal para a prisão e moradias para famílias da baixa renda. Até ali, foram realocadas, entre 1979 e 1984, mais de 2.500 famílias que moravam em ocupações irregulares em zonas centrais de Santiago (Molina, 1985). Nessa época, deu-se início ao processo de interiorização e periferização das prisões; no entanto, até onde pesquisei, não há nenhum estudo acerca desses processos.

187 Entre elas estava Marta Soto, condenada a 14 anos pela suposta participação no atentado contra o intendente de Santiago, o general Carol Urzúa, episódio comentado no primeiro capítulo. Chama a atenção que essa unidade penitenciária feminina, o COF, era administrada pela Congregação das Irmãs do Bom Pastor. Essa ordem religiosa, por decreto supremo, e sob a justificativa da caridade e beneficência, administrou as prisões femininas no Chile por mais de 130 anos, entre os anos 1864 e 1996.
} 
organizações de defesa dos direitos humanos ${ }^{188}$, o grupo regressou, em 1987, na penitenciária feminina, onde estavam antes alocadas. Assim, a prisão de São Miguel voltou a ser recinto masculino, pelo menos, até 2012.

Nesse ano, transformou-se no Centro de Detenção Provisório Feminino Mayor Marisol Estay ${ }^{189}$. Ainda que as autoridades da Penitenciária do Chile anunciaram a transformação como solução à falta de vagas femininas, o motivo era um tanto diferente ${ }^{190}$. Ou, pelo menos, isso pensam os parentes e amigos dos 81 adultos e jovens que faleceram nessa prisão durante o incêndio da madrugada de quarta-feira, no dia 8 de dezembro de 2010191. "Isso é o que eles falam, mas, na verdade, trasladaram os homens porque estavam com medos de nós", diz César - que perdeu Jorge no incêndio, seu irmão de 22 anos.

É 8 de novembro de 2016. Somos aproximadamente 30 pessoas, entre parentes dos falecidos e ativistas congregados, mais uma vez, para exigir justiça. Mesmo as autoridades, no horror da tragédia, comprometeram mudanças no sistema penitenciário e ajuda às famílias dos falecidos, ainda que os parentes esperem que se estabeleçam culpados pela morte de seus

188 Entre as organizações que nesses anos atuavam a favor dos presos, podemos destacar a Fundação de Ajuda Social das Igrejas Cristãs (FASIS), a Vicaría da Solidaridade, a Corporação de Promoção e Defesa dos Direitos do Povo (CODEPU), e a Fundação para a Proteção da Infância danificada por Estados de Emergência (PIDEE).

189 Conforme cifras divulgadas pelo Instituto Nacional de Direitos Humanos (INDH), em 2017, contabilizavam-se 650 presas nesse recinto penitenciário. O informe está disponível na íntegra em: https://bit.ly/2Zc2MVB. Acessado em: 05/03/2019.

190 No Chile, entre os anos 2007 e 2015, a população carcerária feminina quase duplicou. Em 2015, 3.126 mulheres estavam privadas de liberdade, representando 7,4\% do total da população carcerária no país. Deste total, o 58,9\%, era acusadas ou condenadas por porte de droga (Caicedo, 2015). Esse tipo de delito, como no México, na Colômbia e no Brasil, é o que leva o Chile a possuir o maior números de mulheres na prisão.

${ }_{191}$ Este incêndio, o pior vivido na história penitenciária do Chile, contudo, não é único: houve acidentes da mesma natureza, em 2001, na prisão de Iquique (26 mortos) e na prisão de San Miguel (7 mortos). Em 2003, novamente, houve outro incêndio, dessa vez na prisão de Concepción (com 9 mortos). 
entes queridos e que sejam pagas reparações econômicas ${ }^{192}$. A cada dia 8 de cada mês, a rua Ureta Cox, onde situava a prisão, transforma-se em lugar de memória e comunhão. Uma caixa de som toca músicas ciganas. A rua é fechada com faixas do time do Colo-Colo; alguns bebem cerveja, outros fumam sentados do lado do grande mural. Há várias mensagens e murais artísticos dedicados aos falecidos, ao lado dos slogans anticarcerários. Ao redor das grades da cadeia, velas são acessas, e retratos dos mortos, pendurados. Aos poucos, multiplicam-se os rostos daqueles que entraram vivos na prisão e saíram feitos cinzas (hechos cenizas), como lamentam os parentes ${ }^{193}$. Uma jovem aproxima-se do enorme cartaz onde há impresso o rosto do pai de seus filhos, e o beija nos lábios.

Perto dali, dois meninos de cerca de 10 anos que me ouviram falar de Adriana com César, aproximam-se e com respeito perguntam: "Em qual módulo está sua prima?". Prestativos, me explicam apontando a ordem dos prédios que estão logo a nossa frente: “5, 4, 3, 2,1: ali está ela!". A prisão de São Miguel é composta de cinco prédios de quatro andares, cada um com seus respectivos pátios. Cada bloco é chamado de módulo, nos quais são distribuídas separadamente as presas que ingressam pela primeira vez (1 e 2) e

192 Para tanto, os parentes criaram a ONG 81 Razões para Lutar. No momento do incêndio, a população carcerária em San Miguel duplicava a capacidade do recinto e os sistemas de rede seca e hidratante estavam desativados. Os oito guardas penitenciários imputados por delito de homicídio foram absolvidos, em abril de 2014. O juiz José Manuel Rodríguez considerou as provas apresentadas pelo Ministério Público para incriminar os trabalhadores "difusas, imprecisas e contraditórias". Até hoje, eles não receberam reparação econômica do Estado pela morte de seus parentes. Para mais informações da agrupação, recomendo Sangre de Uno: documental de derechos humanos y prisión, dirigido por Juan Pablo Lillo. Disponível em: https://bit.ly/2z4pu7x. Acessado em: 04/04/2019

193 Vale dizer que em outros acessos à prisão, há um memorial construído pela Penitenciária do Chile para recordar os falecidos no incêndio de 2010, mural de granito escuro com o nome das vítimas - um tanto abandonado, sem flores ou algo do estilo. 
as reincidentes ( 3,4 e 5) ${ }^{194}$. Com pequenas pedras, os meninos batem, frenéticos, nas grades metálicas do perímetro exterior da prisão, rompendo o silêncio da noite. O barulho é uma saudação: "!Olhe tia!, excitados me dizem apontando para uma janela de um dos prédios."!Oi chiquillas195!” - gritam felizes, enquanto entre as barras de aço longos pedaços de papel higiênico voam devagar no meio da ar noturno. É assim que as mulheres atrás das grades acenam para nós.

Além de músicas, as caixas de som amplificam as palavras de César. Nesses instantes, a rua transforma-se em palco e os blocos de confinamento, em público. Em seus trinta e poucos anos, de cabelo raspado, olhar vivo e linguajar inteligente, César comenta sobre a passeata que organizaram no mês passado desde a rua Gran Avenida até a prisão; além disso, informa acerca dos preparativos para a atividade de final de ano e avisa do lançamento do livro escrito por um jornalista sobre o incêndio. Entre brincadeiras, ele pede aos guardas (também ouvintes) para dar autorização às chiquillas para

\footnotetext{
194 Esse conjunto arquitetônico é exemplar daquilo que na literatura prisional chama-se de modelo telephone-pole, ou espinha de peixe: um conjunto de blocos paralelos unidos por um corredor central perpendicular. Os primeiros centros penitenciários desse tipo foram inaugurados na Inglaterra (em Wormwood Scrubs), em 1874, e na França (em Fresnes), em 1898. O modelo popularizou-se na década de 1930 e 1940 nos Estados Unidos, sob a justificativa que permitiria uma vigilância contínua e o acesso independente e controlado de cada área operativa. Na América Latina, construíram-se grandes presídios seguindo o modelo, como Carandiru no Brasil (Roth, 2006).

195 Chiquillas e chiquillos são expressões do jargão popular chileno para se referir, com carinho, a pessoas jovens ou com algum grau de inocência.
} 
participar do evento ${ }^{196}$. Um dos meninos especialistas em infraestrutura carcerária - que perde seu tio no incêndio, me busca entre o público e, confidente, propõe: "Quer dar um olá para a sua prima?". No microfone, ele viu uma chance de me ajudar a falar com Adriana. Convite impossível de recusar. Corre, então, animado para avisar César e, em poucos minutos, já tenho um microfone nas mãos. No meio da noite, sem saber se Adriana chegaria a me ouvir, no meio da escuridão, olhando o módulo 2, comecei a falar palavras que hoje não consigo mais me recordar. Mas me lembro muito da pele arrepiada naquele instante inusitado de comunhão. Dessa sensação corpórea, provavelmente, nunca vou olvidar.

O primeiro dia 8 que Adriana passou encarcerada em São Miguel ela ouviu o barulho da rua no meio da noite. A cada dia 8, as guardas penitenciárias ficavam mais tensas, e não era estranho que algumas das autoridades da administração permanecessem até mais tarde supervisando as celas. Gritar pela janela, para Adriana, era o modo de fazer os parentes saberem dos chiquillos falecidos que estavam juntos na dor: laços de solidariedade entre as presas vivas e os parentes de presos mortos. Não foram poucas vezes que, ao ouvir as presas gritarem, as guardas as mandavam calar a boca, agregando com sanha: "Ah! Mas esses já estão bem mortos, não é?". Pois bem, mais ou menos. Nos corredores do presídio, circulavam rumores de que os mortos no incêndio assombravam os guardas, aterrorizando-os ("se les aparecen en mala”). Convivência entre presas, guardas penitenciários e espectros fantasmagóricos. A Adriana, no entanto, a possibilidade de ver um

196 O lançamento do livro Fuego en la Prisión de San Miguel, de Diego González, aconteceu no dia 12 de outubro de 2016 no Museu da Memória, em Santiago. Graças ao trabalho de coordenação de César, entre os assistentes, havia, principalmente, parentes e amigos dos falecidos. Rompendo com as formas convencionais desse tipo de evento, eles pediram a palavra e falaram de luto e de luta. Mães, companheiras e filhas relataram, entre lágrimas e muita raiva, o sofrimento vivido ao longo desses 6 anos, do trato displicente das autoridades e da negação a lhes entregar compensações econômicas. Narraram, inclusive, os transtornos psicológico e a medicação excessiva para sobrepor-se à dor. A falta de justiça, criticavam, de dava pelo simples fato de serem famílias pobres. Entre o público que pediu a palavra, para a minha surpresa, estava uma outra mãe, Ana Luisa, a mãe de Eduardo, Rafael e Pablo Vergara Toledo. Por questão de horário, pediram para deixar a sala. Lá fora, formamos uma fila para comprar o livro: acadêmicos, ativistas e também parentes. Uma mulher, me lembro bem dela, apertava com força a nota com que pagaria o livro que, talvez, pudesse lhe explicar como essa tragédia poderia ter sido evitada. 
fantasma não the dava medo algum, não porque não acreditasse neles, mas sim porque achava muito estranho que os chiquillos fossem incomodá-la: no final das contas, ela era uma presa, assim como eles antes de morrerem.

\section{Presos políticos?}

No Chile, os presos políticos não existem. A verdade é que qualquer regime político democrático nega a existência de presos dessa categoria - o Brasil não é diferente. Mas a democracia não se trata, justamente, da liberdade de expressão e pensamento? O que há, dizem as autoridades quando questionadas a respeito do assunto, são suspeitos e condenados por delitos muito graves sancionados, sejam por leis antiterroristas, sejam por leis que resguardam a segurança interior do Estado. Preso político é uma categoria meta-jurídica, expressão militante para politizar e desjudicializar algo politicamente instituído, mas juridicamente indizível (Oliver e Lorenzo, 2019, p. 196) ${ }^{197}$.

Ainda que possa não existir a codificação de delitos políticos (e, portanto, não haverá presos desta índole), certas regulações penitenciárias que gerenciam de modo diferenciado esses corpos, implicitamente, admitem a sua existência, ou seja, tornam-nos como reais. Para além das definições oficiais, é preciso olhar para os modos pelos quais na esfera jurídico-criminal são traçadas diferenciações internas, embasadas em uma miríade de arranjos, divisões e práticas seletivas formais e informais que regulam o cotidiano prisional e que operam em oposição à figura do preso comum (Bargu, 2015, p. 107). A distinção entre presos políticos e comuns, mesmo que negada institucionalmente, desponta desde o momento em que corpos dissidentes são capturados pelo aparelho estatal, nas detenções policiais espetaculares, nos julgamentos noticiados pela imprensa e nas condenações excessivas (Bargu, 2015, p. 110). Como qualquer fronteira, essas distinções parecem ser reelaboradas constantemente no tempo, no espaço e entre os atores: entre os

\footnotetext{
197 No Chile, nos últimos anos, alguns militares condenados por crimes de lesa humanidade perpetrados na ditadura dizem ser "presos políticos militares". Tal classificação é amplificada por certas ONGs e fundações de direita, que têm se organizado para exigir benefícios carcerários para os "uniformados" presos, discursos que se situam na esfera pública como o dever de resguardar os direitos humanos desses internos - muitos com mais de 80 anos.
} 
próprios presos, entre a administração e os internos e, ainda, entre os presos e os circuitos militantes no exterior

Adriana foi castigada assim que chegou na prisão de São Miguel. Castigada pela administração penitenciária sem que tivesse feito nada para merecer o castigo. Justamente, porque era uma recém-chegada. Ela e outra jovem que foram imputadas pela mesma causa judicial (ataque incendiário de uma delegacia policial) foram trasladadas para a Unidade de Castigo - ou, como preferem dizer os funcionários, para a Unidade de Regime Diferenciado ${ }^{198}$.

O tratamento diferenciado se traduziu em 23 horas de encarceramento por dia, em uma cela de 5×4 metros - diferentemente do regime de 12 horas que regia o restante das internas. Nos 60 minutos que eram permitidas deixar a cela (que compartilhavam com mais 4 mulheres), tinham direito a tomar banho de sol, quando havia. Ou então a usar o único telefone disponível na instituição. Assim sendo, muitas vezes, não chegavam a sair porque preferiam telefonar a seus pais, namorados ou amigas.

A unidade diferenciada era completamente autônoma, com seu próprio pátio e cozinha. Unidade de segregação que, às vezes, Adriana descrevia como uma prisão dentro da prisão. Afastadas, eram impedidas de participar de qualquer atividade esportiva, educativa ou de capacitação laboral oferecida pelas equipes técnicas da administração para as presas alocadas nas unidades "não-diferenciadas". Sendo lugar de penitência, lhes era negado o direito a visitas íntimas - vale dizer, o castigo incluía até o mais íntimo. De qualquer forma, insistia Adriana, pior era a situação das mulheres trancadas em cômodos individuais: 23 horas de encarceramento total, em um espaço de $2 \times 2$ metros, sem luz elétrica nem janela, sozinhas na completa escuridão, muitas vezes sob os efeitos de fármacos.

A Unidade de Castigo, como estabelecem protocolos da administração, é prevista para estadias curtas, delimitando um tempo necessário para "corrigir" as internas que descumprem as regras de convívio indicadas nos regulamentos. Em caso nenhum seria lugar para permanecer meses, como

198 Em visita ao Instituto Nacional dos Direitos Humanos, a gerência de São Miguel negou a existência da unidade de castigo, o que foi rebatido pelo informe da instituição que constatou as condições que descrevo (Instituto Nacional de los Direitos Humanos, 2018). 
aconteceu com Adriana e Rosa - e não só com elas. Outras jovens acusadas de crimes parecidos que chegaram um ano antes a São Miguel também foram enclausuradas, desde o primeiro dia, nessa unidade diferenciada. A mesma segregação foi vivida por outros jovens que entrevistei em razão de causas judiciais análogas a de Adriana e que também passaram meses em prisão preventiva. Jovens homens e mulheres que, além de certa estética comum (tatuagens, piercings, etc.), compartilhavam o fato de que as palavras "anarquismo" e "anarquista” estivessem escritas, uma vez e outra, nos dossiês que os incriminaram.

"Não sei até quando pretendiam nos manter trancadas nesse lugar", rememorava com angústia Adriana durante uma de nossas tantas conversas já fora da prisão. Esses três meses, facilmente, poderiam ter sido mais: só conseguiram sair da unidade de castigo pelas insistentes solicitações de seus defensores, advogados da ONG Defensoria Popular - organização jurídica dedicada à defesa de "lutadores sociais"199. Por fim, quando acolhida a petição de traslado, foram levadas para uma outra unidade de segregação um tanto diferente: a Unidade de Conotação Pública. A esse local, onde Adriana chegaria a passar mais de 600 dias de sua vida, no geral, eram destinadas as imputadas por delitos repudiados pela população carcerária, como a pedofilia, o homicídio de crianças e a tráfico de pessoas. Elas eram isoladas, portanto, para evitar potenciais agressões de parte de outras internas. No caso de Adriana, no entanto, a segregação não tinha nada a ver com esse risco.

Quando chegaram a São Miguel, não foram insultos, mas aplausos o que se ouviram pelos corredores: elas foram reconhecidas pelas internas porque apareceram na televisão no dia anterior. "Olha, são as chiquillas que queimaram os pacos!” - gritavam. "Hacer tele [fazer tevê] é um negócio muito foda, porque significa que você fez uma merda forte, que é uma coisa muito valorada lá dentro, ou seja, assim você ganha um certo respeito”. Era assim que Leandro explicou sua experiência como ex-preso provisório, acusado de tentar queimar com coquetéis Molotov uma viatura da polícia durante protestos noturnos para um 11 de setembro. Em uma prisão regrada por

\footnotetext{
199 A Defensoria Popular foi criada em 2008 em Santiago. A ONG tem se especializado na defesa de sindicatos, de estudantes acusados de armação de bombas, de ativistas mapuches. Em jornais, são alvos de críticas, sendo chamados de "ONG que defende encapuchados". Sobre o ativismo jurídico no Chile, ver: Stevenson (2014).
} 
estereótipos hiper-masculinizados, aparecer na tevê, a seu entender, foi o que o protegeu da necessidade de usar a violência como dever de gênero. Rapidamente, reparou que tinha que ostentar una ficha de loco, ou seja, contar que tentou matar um policial com coquetéis Molotov. Essa foi a dica que recebeu de outros presos: tinha que passar por um mata paco.

"Você é anarquista mesmo?" - assim, com curiosidade, uma mulher perguntou a Adriana quando ela havia recém chegado à Unidade de Castigo. $\mathrm{Na}$ televisão, quando reportadas as detenções, Rosa e outros jovens insistiam nas motivações por detrás do ataque da delegacia policial. Assim sendo, rapidamente, as jovens ganharam o apelido de "As bombas". Outros suspeitos também presos em decorrência de violência antissistema seriam chamados de "Molotov" e "Punki". Brincadeiras sobre explosões e incêndios na hora de jogar futebol não seriam infrequentes no cotidiano.

As condições materiais da Unidade de Conotação Pública, onde foram trasladadas, eram minimamente adequadas quando comparadas com o resto da superlotada prisão ${ }^{200}$. No entanto, a convivência com as mata guagua [bebês] resultava bastante desgastante - transtornos psicológicos e condutas esquisitas que alteravam o cotidiano do espaço, situações que Adriana imaginava não acontecer no convívio com presas comuns. De fato, no período em que passou na Unidade de Castigo, ela recebeu afeto e cuidado de mulheres acusadas de roubos e outros delitos do tipo. Assim, por exemplo, quando chegou morrendo de fome no primeiro dia em São Miguel, uma das presas havia organizado uma refeição especialmente para ela e Rosa: "Sabia que chegariam porque as vi ontem na tevê" 201.

\footnotetext{
200 As celas Módulo de Conotação Pública são de 4X5 metros e moram 2 ou 4 mulheres. Adriana descrevia esse espaço como uma "casita" dentro da prisão, com cozinha e banheiros próprios, isoladas do resto.

201 Essa fome que Adriana recorda como descomunal faz parte da experiência de todo preso no Chile. Os tempos de espera entre a delegacia policial e o Centro de Justiça, quando formalizados, pode chegar a 24 horas. Nesse período, a Gendarmeria do Chile não oferece nenhum tipo de alimentação. É prática institucionalizada fazer com que os imputados cheguem esfomeados a ouvir o decreto de medida cautelar, e logo depois, na prisão. É prática de solidariedade entre os presos receber os recém chegados com alimentos ou, pelo menos, deixá-los passar primeiro na fila do refeitório, como foi o caso de Leandro.
} 
Com esses antecedentes, cabe a pergunta: por que imputadas sem antecedentes criminais e sem problemas de convívio foram dispostas em unidades de castigo e isolamento da população carcerária comum? No entender de Adriana, a administração tomou a decisão para impedir que elas ficassem próximas de outras jovens que estavam presas em São Miguel por causas parecidas. Ou seja, para ela, se tratava de impedir que as presas políticas pudessem se reunir. Isoladas, portanto, pelo risco que suporia a sua convivência e que poderia se traduzir na organização de greves de fomes, motins e fugas, tal como acontecia antes, na Prisão de Máxima Segurança (CAS), nos anos 1990. Por meio da invocação desses antecedentes históricos e dos conflitos carcerários na transição chilena, Adriana tornava inteligível a sua experiência prisional.

No entanto, para a Gendarmeria do Chile, nada de político haveria na decisão do isolamento. A distribuição de cada interna respondia à uma avaliação sócio técnica elaborada com base em critérios como perfil criminológico, compromisso criminal e tipo de delito. Informações acerca da composição familiar, o grau de escolaridade, antecedentes criminais, mas também a presença de tatuagens e o jeito de falar, eram ponderados para determinar o nível de internalização do que a instituição penitenciária gosta de chamar de "subcultura criminal" (Gacitúa, 2013). As consequências desses cálculos e classificações da população carcerária são que os internos avaliados como de "alto risco" eram tratados de acordo com critérios de máxima segurança. Assim, por exemplo, nos traslados entre a prisão e o Centro de Justiça, Adriana era transportada sozinha em um carro blindado especial, algemada nos pés e nas mãos, e vigiada por guardas da tropa de elite da Gendarmeria do Chile (conhecidos pelo acrônimo TAR - Traslados de Alto Risco). Impedia-se, portanto, que ela viajasse junto com Rosa ou outras internas que iam na mesma direção ${ }^{202}$.

\footnotetext{
$202 \mathrm{Na}$ sala de audiência, ela e outros jovens imputados foram custodiados, cada um por dois guardas armados e vestidos com coletes à prova de balas, que ficaram, praticamente, colados a eles. Essa proximidade corporal, às vezes, é difícil de distinguir do assédio e da provocação: sempre algemados, nos pés e nas mãos, os trasladaram mediante empurrões ou assegurando com força desnecessária seus braços. Inclusive, em plena audiência, os guardas, bem perto deles, ficavam falando baixinho acerca de experiências sexuais, ou se referindo a parentes e amigos que os estavam acompanhando como público, o que Adriana e Rosa entenderam como assédio.
} 
Sendo Adriana, Rosa e meus outros interlocutores jovens universitários e sem antecedentes criminais, quando capturados pela polícia, poderia se deduzir que, finalmente, o tipo de crime era o fator que decidiria a suas respectivas posições nas categorias de segurança usadas pela administração penitenciária. Qualquer imputado pela lei de segurança no interior do Estado, ou pela Lei Antiterrorista, ipso facto, transforma-se em presos de alta periculosidade, mesmo que sejam investigados por crimes sem vítimas (só paredes, vidraças, metais) - como neste caso analisado. Seria possível classificar de outro modo suspeitos de atacar bens jurídicos tão incomensuráveis como a paz social, o Estado de direito e a segurança interior do Estado?

No entanto, mesmo negando se tratar de presos políticos, havia certo consenso de que eram distintos. $\mathrm{Ou}$, pelo menos, isso estava insinuado em um informe redigido por um dos policiais à paisana que perseguiu nas ruas e nas redes sociais Adriana e outros jovens suspeitos: "Com base nos antecedentes existentes, podemos dizer que o grupo investigado se acha à margem do comportamento usual dos delitos comuns". Tal diagnóstico justificou que a Brigada de Reação Tática Metropolitana (BRTM) participasse da captura dos jovens. Essa tropa de elite, nas palavras da instituição, é um órgão tático criado para auxiliar em operações de "alto risco", como a captura de criminosos de alta periculosidade e, veja-se bem, operativos antiterroristas. Trata-se, no limite, de uma força de elite treinada no Chile e no exterior para lidar com conflitos "não convencionais" - termo caro no campo da contrainsurgência contemporânea.

Assim foi que as forças dessa brigada, sob as ordens do Ministério Público, chegou no meio da madrugada e de forma simultânea, até as moradias de Adriana e de outros quatro jovens. Rosa ainda se lembra do laser vermelho apontado na frente de seu pai. De pijamas, no meio da sala, não conseguia entender se estava acordada ou não. Que outra coisa podia ser aquilo que não um pesadelo, com toda a sua família, seus pais e irmãos, rodeados de policiais de preto, armados até os dentes e mascarados, gritando: deita no chão, caralho!203

\footnotetext{
203 Os integrantes das unidades táticas participam com os rostos ocultos supostamente por razões de segurança.
} 


\section{Deita no chão, caralho!}

Dos franco-atiradores não só se lembrava Rosa. Em 2010, um grupo de 12 jovens foi acusado de integrar uma "associação ilícita informal de caráter terrorista” que, conforme o Ministério Público, teria perpetrado mais de 30 ataques explosivos em Santiago. Vários dos suspeitos moravam em uma okupa. A invasão da polícia ao local foi, simplesmente, espetacular. Um "enxame de pacos". Com esta metáfora, Wary descreveu o tamanho da equipe policial que chegou naquela madrugada até a ocupação. Tal como Rosa, recordava muito bem dos policiais mascarados. "Deita no chão, caralho!” aos gritos, irromperam os agentes com seus uniformes pretos, coletes e balaclavas. Os jovens se negaram a seguir a ordem, mas, em segundos, foram derrubados a pontapés e socos. Em poucos minutos, já estavam algemados, com gás pimenta nos olhos e com camisetas cobrindo as suas cabeças gestos não de ocultamento, mas de desorientação sensorial. O operativo foi acompanhado o tempo todo por um helicóptero. $O$ barulho das hélices aumentava a sensação de ataque - parecia guerra.

$\mathrm{Na}$ frente da casa, aguardando, estavam todos os canais de televisão. "Chega do Estado Policial" - gritaram alguns dos jovens suspeitos que, agora, estava com seus rostos descobertos. "Era importante sair dali erguidos, olhando de frente, nunca para o chão, como fazem os delinquentes", me explicava Wary. No momento da detenção, o corpo deve comunicar que você não é um criminoso, mas um preso político. Nos últimos dez anos, são várias as fotografias que têm circulado por jornais acerca desse instante tão particular que é o encontro entre os suspeitos de serem "anarquistas-atirabombas” e as câmeras da televisão. Hoje, pela quantidade dessas detenções, já poderiam ser tratadas como corpus fotográfico: entre elas, há gestos que se repetem, há um olhar em comum. Alguns aproveitam para politizar o momento da captura, dizendo consignas; outros, cospem nos jornalistas ou simplesmente oferecem o seu melhor sorriso. Mas sempre olhando de frente, sempre com seus corpos em levante.

Sobre esse operativo policial, chegou-se a comentar nas sessões contra os moradores do okupa, julgamento que se estendeu por 6 meses, sendo um dos mais longos da história chilena. Por ordem do promotor público que 
liderou a investigação, deu-se leitura na sala de um documento extraído pela polícia de um blog anticarcerário que narrava o operativo:

Evidência 1389. A petição do Ministério Público, lê-se na página 14, o seguinte: "Uma tropa de elite, grupo de assalto, franco-atiradores, helicópteros, todos os novos brinquedos para o show no centro de Santiago. A casa é destruída e os companheiros são presos e transferidos para uma delegacia da polícia. Eles são filmados, despidos e ameaçados. Se eles não cooperarem com a investigação, vão ver as fotografias do estado em que o corpo de nosso irmão ficou... A polícia, no anseio de obter resultados, entra na casa com um recipiente cheio de pólvora negra, continua o circo, não queremos falar de montagem, mas, olha, é certo que a pólvora foi coisa da polícia". Logo depois, se refere à entrada, ao registro e à resistência: "A opção mais sensata era abandonar a casa, mas não fizeram isso. Se o Mauri tivesse escolhido esse caminho, hoje, ele estaria vivo. Mas ele morreu em guerra, ele escolheu o caminho mais difícil”. Na página 17, há uma citação a um texto cuja autoria é atribuída a Mauricio Morales: "Arme-se e seja violento, belamente violento, até tudo explodir, porque qualquer ação violenta está plenamente justificada pelos séculos de violência a que têm-nos submetido, arme-se, queime, conspire e seja violento. Mauri”. Fim do documento (Sentença "Caso Bombas", Tercer Tribunal Oral en lo Penal de Santiago, 2011)

Por meio da leitura da crônica, o Ministério Público buscou não ilustrar o excessivo operativo policial e sim, evidenciar a suposta relação entre os jovens imputados e o anarquista morto em imolação involuntária, em 2009: Mauricio Morales, com quem abri a introdução desta tese. A bomba que carregava na sua mochila para atacar uma escola de guardas penitenciários explodiu antes do tempo, o que causou sua morte de forma instantânea. O Ministério Público arguiu que, entre os jovens vivos e o jovem morto, havia vínculos de amizade e, também, de organização criminosa. Desde o seu falecimento, o nome e a imagem de Morales transformaram-se em provas incriminadoras. $\mathrm{O}$ momento em que seu corpo explodiu foi identificado pelos analistas em inteligência como o ponto de inflexão da radicalização do movimento anarquista insurrecional chileno. A imagem do corpo decepado de Mauricio Morales foi exibida, em inúmeras oportunidades, na sala da audiência contra os moradores da okupa, projetada em uma grande tela como evidência criminal. No entender dos jovens, os promotores queriam ver a reação emocional deles diante da fotografia do cadáver decepado. Uma reação 
muito intensa revelaria que, de fato, quem eram os mais próximos e, portanto, os mais suspeitos.

No falido ataque anti-penitenciário, as investigações determinaram que houve, ainda, participação de um segundo indivíduo: as câmeras de segurança capturaram uma figura mascarada no momento da fuga e que, desde daquele momento, passou a assombrar as investigações policiais. No julgamento, Cristian Pérez Mancilla, nessa época, chefe da Direção de Inteligência Policial de Carabineros do Chile (DIPOLCAR), acusou a um dos jovens de ser o misterioso acompanhante de Morales. Dois anos depois, em 2012, o mesmo chefe policial iria acusar um outro jovem preso pela polícia de um ataque explosivo a um caixa eletrônico em Santiago204. Para justificar, o oficial revelou que o jovem tinha participado, um ano antes, de uma homenagem póstuma organizada em uma okupa pela memória de Morales.

Veja-se bem: assim como na ditadura, os funerais de militantes eram assediados pela polícia; hoje, os atos de recordação desse anarquista morto transformaram-se em atividades a serem vigiadas. No julgamento, o chefe de inteligência confidenciou que policiais à paisana fotografaram os assistentes no ato, entre eles, o jovem acusado de atacara o caixa eletrônico. Os eventos dos presos políticos também foram alvos de vigilância. Em atividade cultural solidária a Adriana, em uma tarde de domingo, os primeiros a chegar foram, veja-se bem, policiais. Uma viatura estacionou e os operativos pediram as carteirinhas de identidade de alguns dos assistentes, de forma arbitrária. Para esses jovens, frequentadores da cena punk santiaguina, a abordagem policial não foi por acaso. Os policiais estavam nesse lugar e nessa hora para "sapear" (espiar).

Os jovens imputados detidos pela polícia na casa okupa foram internados na unidade de castigo da Cárcel de Alta Segurança (CAS) - cárcere

204 Condenação “Caso Caixa Eletrónico” Cuarto Tribunal Oral en lo Penal de Santiago, 2012. 
construído para os presos subversivos nos anos $1990^{205}$. O tratamento dado a eles foi ainda mais severo que o relatado por Adriana e Rosa: cada um foi trancando sozinho em uma cela por três dias seguidos. Nesse interim, perderam a noção do tempo. Os guardas penitenciários falavam com eles no momento de entregar-lhes alimentos. Não puderam nem receber a visita de seus advogados. Depois desses dias, passou-se a aplicar o regime de 23 horas de encarceramento total com apenas uma hora de pátio. Como qualquer outra unidade de castigo, não havia acesso a atividades de lazer, tampouco educativas ou visitas íntimas. Depois de meses, finalmente, conseguiram ser trasladados para a unidade de Alta (e não máxima) Segurança, como resultado da greve de fome. Os 14 acusados só beberam líquidos por mais de 50 dias. O objetivo era, por meio da greve, denunciar as irregularidades da investigação policial, que fez uso de informantes pagos e manteve documentos em segredo, fora do alcance das defesas. Havia a exigência de que não fossem processados pela lei antiterrorista, que coloca em risco de condenação perpétua alguns dos imputados:

Hoje, segunda-feira, dia 21 de fevereiro, já cumpridos os prazos da investigação (mais de 18o dias), damos início a uma mobilização do tipo Greve de Fome Líquida Indefinida. Usamos o nosso corpo como meio para exigir: 1. A liberdade imediata de todxs xs imputadxs desta causa judicial. Nem um dia mais de investigação. Julgamento agora! 2. Fim da Lei Antiterrorista. Não mais testemunhas encobertas. 3. Traslado para fora da máxima segurança e melhorias carcerárias.

Recusar-se a ingerir alimentos deu sentido ao confinamento prisional. Cada dia em greve significava mais um dia de resistência ativa, e não só na espera das decisões dos juízes. Desse modo, deixaram de se sentir submetidos à vontade da engrenagem jurídico-penal. A greve de fome, ainda,

$205 \mathrm{O}$ atual nome oficial desse recinto penitenciário é Unidade Especial de Alta Segurança (UEAS). Conforme dados do Instituto Nacional de Direitos Humanos (2018), o recinto com capacidade para 306 internos contava, em 2017, com 115 pessoas na Unidade de Alta Segurança, 95 na Unidade de Segurança Máxima - que opera como módulo de castigo e tem celas individuais de $2 \times 2,5$ metros. Na época, chegaram imputados por crimes como narcotráfico, crimes sexuais e associações de tipo terrorista. Ainda, há uma terceira unidade, o Anexo Capitão Yaber, para imputados por delitos econômicos. Mesmo sendo destino de criminosos de colarinho branco, as condições materiais são absolutamente diferentes das cadeias comuns. Em 2017, havia 12 imputados naquele local. 
situava-os em um contínuo histórico de lutas anticarcerárias. "Você está se mobilizando, movimentando o corpo e tudo" - explicava Wary. Técnica de autodestruição onde a própria vida é transformada em arma de luta política (Bargu, 2015). Por meio dessa violência auto infligida, buscava-se visibilizar a realidade do confinamento e a penitência à qual foram forçados aqueles que, aos olhos do Estado, eram um outro radical: terroristas desalmados.

Vinculado às tramas de resistências prisionais atuais e passadas, Wary se lembra que, nos primeiros dias, recém-chegado na prisão, um guarda de mais idade chegou a falar com ele: "Olha, isto aqui já não é como antes" - e então começou a citar nomes de presos políticos da transição chilena. "Esses hueones já não mandam mais aqui; agora, mandamos nós e os criminosos. Vocês não são nada e ninguém os respeita! Esquece greves de fomes e essas merdas todas". Por meio da negação de uma condição especial, paradoxalmente, o guarda reconhecia que, de fato, eles eram diferentes: "Senão, por que teria se quiser chegado a me falar disso?" - refletia Wary. Contudo, mal sabiam os guardas mais novos dessas histórias dos anos da redemocratização, de fugas, subversivos, túneis, motins e greves de fome. Entre os presos, a maioria por conta do narcotráfico, tampouco eram de conhecimento essas experiências militantes de "prisão combativa" do passado.

\section{Duplos malignos}

"Você acha que não posso te desaparecer, seu merda?". Essa frase ficou gravada na memória de Leandro enquanto recebia golpes, tombado nu no chão de uma delegacia da polícia. Ele e outros cinco jovens foram presos em uma noite de 11 de setembro, quando, mascarados, entre pneus e barricadas, atiravam coquetéis Molotov em um bairro popular de Santiago. Fugindo da polícia pelas ruas da comunidade, acreditaram encontrar refúgio na casa de um vizinho que tinha deixado a porta aberta. Na ditadura, esse era o sinal para os perseguidos pelos pacos, para saber que podiam entrar a se esconder em um ambiente de confiança. Mas dessa vez foi diferente: era uma 
armadilha. Encurralados, foram entregues diretamente à polícia ${ }^{206}$. Sendo uma noite de 11 de setembro, efeméride funesta do Golpe de Estado de 1973, o policial escolheu falar justamente de desaparecidos, e isso o impactou mais que os socos na boca, os chutes nas costelas, as joelhadas na barriga e os golpes na cabeça com a coronha da pistola. "Eu moro aqui faz anos, conheço cada canto desta porra, então eu posso te desaparecer se eu quiser" reiterava o policial enquanto batia nele reiteradamente. A cena, assegurou o jovem, foi filmada com um telefone celular por uma funcionária da Direção de Inteligência Policial de Carabineros do Chile (DIPOLCAR), que ria burlescamente, tal como outros policiais que comemoravam os golpes: "Agora você vai virar homem de verdade! Com a cara descoberta você é um merda só”.

Para Leandro, a sanha com que era golpeado, ele e os outros jovens, tinha a ver com o fato de serem presos por tentar queimarem uma viatura da polícia, ou seja, tratava-se de um ato de vingança. O tom dos policiais era de muita agressão e exaltação. "Meio tortura" - avaliava ele, golpes e vexames à vista de todos, na mais completa normalidade. Horas depois, com um dos jovens sangrando, foram levados para um serviço de saúde e forçados a assinar um documento que atestava que não existiu lesão alguma. Antes disso, na delegacia, quando recém chegaram, Leandro ficou pasmado por outras duas razões. Em uma mesa, estavam dispostos objetos, documentos e toda uma parafernália política que depois seriam usados para incriminá-los:

Tinham um bidão de gasolina, panfletos, um cartaz, todos com mensagem muito fortes, muito insurre, que falavam de cabros [jovens] já mortos, ou muito envolvidos no rolê, então, as provas tinham relação com coisas que haviam acontecido no passado...

206 Para o Dia do Jovem Combatente, assim como para o 11 de Setembro, nos bairros identificados como críticos pelo risco de protestos violentos, efetuam-se operativos policiais cada vez mais sofisticados. Nos dias anteriores, observa-se no perímetro externo viaturas da polícia de choque, e não são estranhos os controle de identidade dos moradores. O uso de helicópteros faz parte do repertório de policiamento e assédio. Não há publicações acadêmicas que discorram sobre a espacialização da polícia para essas datas, no sentido de investimentos para o controle e repressão. Mas, conforme algumas falas que tive com moradores de um bairro afetado por essas intervenções, os vizinhos criticam as ações dos jovens para comemorar esses dias, não tanto por discordarem de algumas ideias, e sim pelos transtornos causados pela polícia na "caça” aos "encapuchados". 
estava tudo articulado! Então, era óbvio que era um trabalho da inteligência policial.

Mais "surreal", no entanto, foi quando, no meio dessa noite de 11 de setembro, irromperam na delegacia outros jovens. Vestidos da mesma forma que ele, não eram jovens combativos, mas policiais encapuchados. "Entraram um monte de policiais vestidos como punkis, com tatuagens, com o cabelo raspado e pintado, as garotas vestidas todas de preto; todos eram pacos! Foi uma coisa muito, muito foda mesmo!”. Nesse instante, aos olhos de Leandro, se corporificou essa figura elusiva, desconcertante e dúbia tão própria da inteligência policial: o agente provocador, o que no Brasil é chamado de "P2" $\mathrm{P}_{2} \mathrm{O}$.

Entre ativistas e militantes, a discussão sobre policiais infiltrados é corriqueira. Para as lideranças dos movimentos sociais, todo manifestante violento seria nada mais que um policial encoberto que, mandados pelas autoridades, busca a criminalização do movimento. Não foram poucas as vezes que mascarados foram apontados nos protestos de rua de serem embusteiros policiais, reconhecidos pelo jeito de falar, de se aproximar de outros policiais. Na Internet, ativistas disponibilizam vídeos e fotografias dos falsos encapuchados, como a imagem logo abaixo (Fig.19), tirada em uma passeata estudantil em Santiago, em 2015. Pelo corte de cabelo e as roupas "hippies" muito bem arranjadas, mas sobretudo pela evidente familiaridade com os policiais do choque, o homem suspeito foi escrachado nas redes sociais como agente infiltrado.

Os policiais-encapuchados chegaram a ser assunto de conhecimento público. Em canais de televisão mainstream, divulgou-se uma cena que em certa medida dá conta da dimensão especular da perseguição policial (Aretxaga, 2006; Chamayou, 2012). No meio da rua, um encapuchado que estava batendo em um policial, de súbito, é preso por um outro encapuchado que estava junto com ele 208 . A gravação só podia se explicar, insistia o jornalista que comentava o clipe, pela participação de policiais infiltrados. A cena é perturbadora, porque capturado e captor performatizam uma figura similar: mesma estatura, mesmo peso e estão vestidos com as mesmas roupas,

207 Trata-se d seção de inteligência da Polícia Militar.

208 Vídeo disponível em: https://bit.ly/2knRBdZ. Acessado em: 05/07/2019. 
calça jeans, moletom com capuz preto e mochila. Visando "caçar" o criminoso, a polícia adotou, ou melhor, encarnou as formas do inimigo, daquele que é alvo da perseguição. Nesse caso, no processo de imitação tática, o policial agregou mais uma prenda, que foi a única coisa que o diferenciou do encapuchado real: uma hatta, símbolo da luta pela libertação da Palestina209.

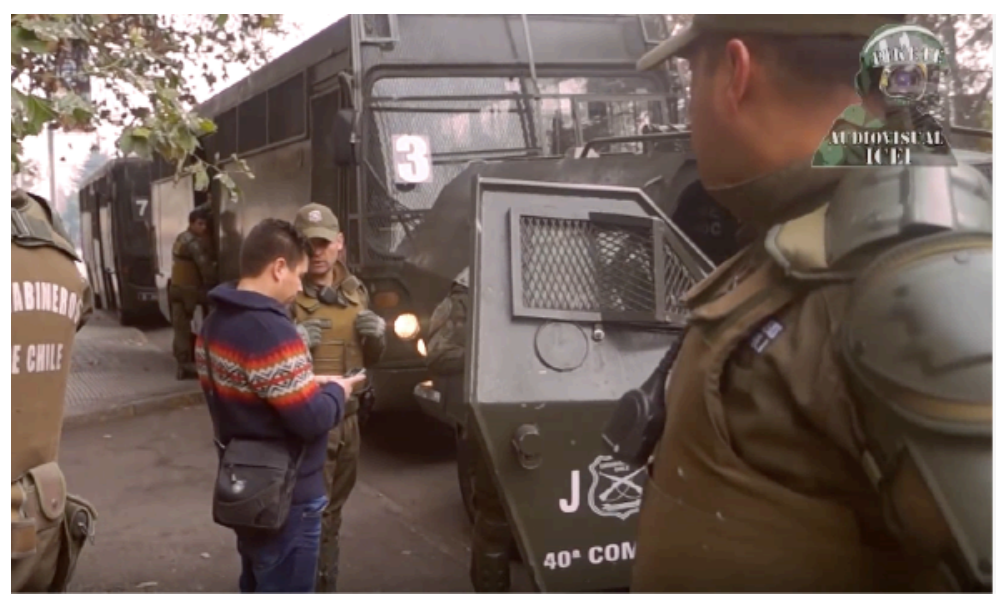

Figura 20: Falso

manifestante (ICEI, 2015)

Em outras ocasiões, os que decidem desmascarar os infiltrados são os próprios encapuchados. Correrias no interior do Cemitério Geral de Santiago, entre tumbas e flores, de mascarados atirando pedras e golpeando outros encapuchados ("mascarados fictícios") não são infrequentes. Com esse pano de fundo, cabe a pergunta: como serão esses momentos em que os policiais treinam a arte do mascaramento? Não deixo de imaginar uma sala com jovens policiais ensinando, uns aos outros, a estratégias insurrecionais, mostrando como amarrar as camisetas do jeito certo sobre o rosto, aprendendo a preparar coquetéis Molotov, a mover os seus corpos como se fossem encapuchados que odeiam os pacos. A decisão policial, amparada pelo Ministério Público, de usar agentes infiltrados em protestos de rua, é investimento institucional para o desenvolvimento entre os policiais de habilidades

209 Sobre a fantasia de manifestantes, em fotografias divulgadas na imprensa para noticiar a inauguração de um centro de treinamento no Chile (com financiamento dos EUA) para missões de paz em zonas urbanas, apareceram militares de capacete azul, se enfrentando com homens fantasiados com hatta palestinas e roupas esportivas. Imagens idênticas foram apresentadas por Stephen Graham (2010) no caso das instalações de treinamento militar nos EUA: homens e mulheres, por pouco mais de U\$20o por dia de trabalho, se comportam imitando multidões de árabes revoltados. Mas, outras vezes, são os próprios militares que interpretam o papel dos insurgentes. 
miméticas que permitam capturar os "violentistas". Trata-se, para alguns autores, de uma empatia tática (Bubandt, 2009; Bubandt e Willersey, 2015), onde o exercício de se colocar no lugar do outro, nos sapatos dos outros, não nasce de uma virtude moral, mas do desejo mesmo de perseguição e destruição ${ }^{210}$.

\section{Empatia tática}

No interior das prisões, ainda que não haja falsos mascarados, circulam outras personagens ambíguas. No caso de Wary, o jovem da okupa, além do guarda penitenciário que chegou a lhe dizer que ele não era um preso político, ele foi abordado por um outro guarda, que se aproximou com uma atitude radicalmente diferente. Em vez de agressividade, mostrou-se suspeitosamente amável. Em tom um tanto quanto paternal, chamou-o pelo seu apelido e começou a lhe perguntar como estava, como se sentia - atitudes fora do que ele esperava desse lugar e desse alguém usando uniforme. "Fale se você precisar de alguma coisa, cara, o que for, é só dizer" - insistia o guarda. Especificamente, oferecia-se para ajudá-lo a entregar cartas aos jovens imputados pela mesma causa judicial que permaneciam em outros recintos penitenciários, bem como arranjar visitas ${ }^{211}$.

Ante a desconfiança de Wary, o guarda tratou de demonstrar que suas intenções eram sinceras, dizendo que tinha amigos em uma universidade conhecida pelas preferências políticas de seus professores e estudantes, à

\footnotetext{
210 "The strike" (1924), de Sergei Eisenstein, nos oferece uma versão ficcional desse treinamento. Aos seis minutos de iniciado o filme, o chefe da polícia saca de sua escrivaninha uma pasta na qual aparecem as fotografias de policiais-espiões. A câmera mostra os rostos dos agentes impressos no documento. Logo depois, aparecem seus apelidos, vários dos quais referindo-se a animais, para, no ato seguinte, o espectador vê-los trocar de roupas, colocar barbas falsas: ou seja, caracterizarem-se. Seguidamente, eles são recebidos por um homem em um bizarro laboratório cheio de animais, onde seus rostos são superpostos com os rostos de ursos, corujas e macacos. O homem duplo, o policial híbrido, o agente encoberto em mutação. Pronto. Os agentes secretos fantasiados de vagabundo, de vendedor de sorvete e, claro, um deles de operário, começam o operativo de infiltração em uma indústria em greve. Nessa cena, conforme a análise de Michel Taussig (1999), vemos a magia do cinema ir junto à magia do Estado.

${ }^{211}$ Assunto delicado: se por algum motivo há a acusação de conformar uma associação ilícita, quanto mais evidências a polícia tem sobre a proximidade e os laços entre você e os outros suspeitos, então mais força adquire a hipótese policial.
} 
esquerda do leque político. Essa indicação gerou o efeito contrário: por que um guarda iria ter amigos, precisamente, naquele lugar? Além disso, como se poderia chegar a confiar em um paco? - questionava Wary212. Do que se tratava essa impostada cordialidade? Encenar o papel de "bom-policial" (good cop) dos filmes americanos de detetives, aqueles que buscam ganhar a confiança dos suspeitos para, logo, incriminá-los? Da mesma forma em que essa personagem apareceu misteriosamente, ela nunca mais apareceu. E houve uma outra que emergiu na cela de outros dois jovens imputados pela mesma causa judicial: um homem por volta dos 50 anos, carismático e de origem cubana, de codinome Raúl. Entre partidas de xadrez, aos poucos, foram trocando ideias de política e da vida; ele dizia concordar com as injustiças do caso contra os jovens. Até começou a insultar um deles imputados no caso que aceitou colaborar como delator da polícia: "Dedo duro de merda" - lhe gritava junto aos outros presos. Depois de quatro meses de convívio, de um momento a outro, o homem sumiu, causando alerta entre os jovens: mas quem era o cubano?

Uma pesquisa jornalística iria corroborar as suspeitas: era um informante do Ministério Público (Tamayo, 2012). Em concerto com a Gendarmeria do Chile, um dos promotores que liderava a investigação contra os jovens decidiu oferecer o serviço de informante diretamente a Jesús Oviedo Mendieta, um cubano residente no Chile e condenado a 7 de prisão por falsificação de passaportes e documentos públicos para migrantes. Aquele que seria informante do Ministério Público era, ele próprio, alvo de investigações da Agência Nacional de Inteligência (ANI), que, em 2005, ficou alarmada com as atividades desse ex-agente do serviço de inteligência cubano. Em certos circuitos, esse homem se apresentava como um ex-espião da URSS e assegurava haver desfalcado o governo cubano - ou seja, no mínimo, uma personagem da qual seria razoável desconfiar.

Pois bem, justamente ele foi contatado para trabalhar de informante, em troca de benefícios carcerários. A cada semana, o réu-informante ("passarinho", "dedo duro”, “cagueta”, “X9”, no jargão popular) enviava uma

\footnotetext{
212 Guardas penitenciários são chamados da mesma forma como os policiais: afinal, não haveria muita diferença, pois ambos são especialistas em violência sob as ordens do Estado. Também, para ambos, usa-se o termo "yuta".
} 
carta escrita à mão endereçada ao promotor reportando seus avanços investigativos: "Como ordenou, efetuou-se o meu traslado para a Unidade de Segurança Máxima sob todas as medidas de discrição, facilitando a aproximação e a penetração ${ }^{213}$ do objetivo" - dizia o cubano no primeiro informe (Tamayo, 2012, p.91). Nas dezenas de cartas integradas ao dossiê da investigação, em um primeiro momento sob sigilo e convertidas em evidências, o cubano informava que os jovens imputados estavam, nada menos, planejando assassinar um promotor público e a sua família.

Em recompensa por seus serviços, que foram atendidos, o réu alcançou benefícios carcerários. Assim como no caso de Joana analisado no Capítulo 1 desta tese, décadas depois, caberia nos perguntar, uma vez mais: como é que um charlatão como este foi considerado fonte confiável de informação e, pior ainda, colocado em comunicação direita com o Ministério Público chileno? Como confiar nos esquemas da delação premiada? Este último fato parece ser ainda mais indignante aos olhos do jovem que compartilhou a mesma cela com ele: "Não podia ser que, assim tão facilmente, havia chegado um sujeito com esse passado criminal e com a clara intenção de obter benefícios carcerários, e que ele fosse ouvido e considerado como um informante quase profissional por todos os organismos do Estado" (Tamayo, 2012, p.95-96).

A seguir, é possível ver uma reprodução exata de uma das cartas escritas pelo cubano, que pedia aos jovens papel para poder escrever as cartas que os delatariam:

\footnotetext{
213 A metáfora da penetração, me faz recordar da divulgação pública acerca do policial militar, de codinome "Baltazar Nunes", que se utilizou de uma identidade falsa para se aproximar de mulheres militantes de esquerda em redes sociais, como parte de investigações policiais contra os protestos em 2013 em São Paulo. A “infiltração sexual” em movimentos sociais, efetuada por agentes da polícia e de colaboradores civis, é uma tecnologia de vigilância estatal que faz parte do atual repertório de táticas de vigilância e controle das esferas privadas de ativistas, e isso não só no Brasil. Sobre essa questão, ver o trabalho de Loadenthal (2014).
} 
SR. Alejandro Peña Ceballos

Fiscal Regional zona sur

Ministerio Público

Presente

Como usted puede apreciar no he perdido ni un segundo, pese a las dificultades q'existen saqué toda la información q'pude ahora le queda evaluar las q'se utilizarán este trabajo tiene mucha importancia pues le entrega un patrón de cómo el objetivo se desenvuelve y piensa yo no les daré tregua, pondré todo de mi engaño e inteligencia para frenar esta seguidilla de bombazos, es una tarde de todos donde cada cual debe cooperar para q'el trabajo de sus frutos, pienso q' esta asociación ilícita no tiene escrúpulos, por q' ponen en riesgo además de la tranquilidade ciudadana la vida de su familia, de la mía, de pueblo. Yo cuando estreché su mano le entregué mi respeto al trabajo q' ustedes realizan, y la seguridad q' me ayudarán, y como usted dijo q' este tema es de interés del presidente de la república, me enorgullece trabajar con su equipo.

Le saluda francamente.

P.D. Necesito un contacto

Urgente q'ya prepara

Algo grande.

Santiago. 08.12.2010.

Além do cubano, na investigação, utilizaram-se "testemunhas protegidas”: ou seja, informantes civis cuja identidade era mantida sob sigilo no dossiê e eram pagos para entregar informações privilegiadas. Por ação dos defensores que exigiram ter acesso a essas informações, porque eram provas de peso para a incriminação dos imputados, ficou-se sabendo que um vizinho da okupa participou como testemunha de acusação - um indivíduo, também, com antecedentes criminais. A pergunta que era colocada pelos jovens e pelas organizações era: Qual é a seriedade de quem é pago por delatar?

O fato é que esses informantes foram considerados válidos, ou pelo menos razoáveis, pelo Ministério Público. No entanto, a partir de um movimento contrário, o livro da jornalista Tania Tamayo, que revelou o caso do cubano informante - e que hoje é Diretora da Escola de Jornalismo da 
Universidade do Chile -, foi catalogado como panfletário e pouco sério pelo ex-Ministro do Interior, Rodrigo Hinzpeter, no governo de Sebastián Piñera (2010-2014). Inclusive, a respeitada jornalista chilena foi acusada por um deputado da direita de ter sido imparcial, porque um dos jovens imputados, assim como o meu caso com Adriana, era seu primo214.

\section{Sombras no campo}

Figuras ambíguas como as que foram descritas logo acima, por certo, não estiveram alheias à minha experiência de campo. Minha primeira vivencia a esse respeito se deu no início do meu trabalho de campo, enquanto participava de um evento organizado para arrecadar fundos para Adriana, onde participamos parentes, amigos do bairro e da universidade. Havia, também, pessoas que não a conheciam diretamente, mas que eram seguidores de algumas das bandas de punk que esse dia iriam se apresentar. Em uma roda, conversando sobre o julgamento e a situação de Adriana com algumas companheiras da faculdade, eu falei com um jovem, com seus 20 e poucos anos. Ele estava sozinho, tinha o cabelo cumprido e estava vestido com calça jeans e camiseta. Porém, quando perguntei a ele se conhecia Adriana, ficou nervoso: "cheguei aqui porque gosto de tal banda, mas olha, sério, eu não sou um policial! Fica tranquila!” - falou entre risos. Eu não tinha cogitado tal possibilidade, mas a resposta me deixou um tanto incomodada. Quem era ele talvez não seja importante para o meu argumento aqui, mas o receio do jovem e o meu desconforto revelam o ambiente de desconfianças daqueles anos, bem como a sombra fantasmagórica do Estado, encarnada em possíveis agentes à paisana e civis informantes, que se projeta na cena anticarcerária.

A segunda experiência com essas personagens ambíguas aconteceu na saída da sala de audiência. No corredor, estávamos esperando um amigo de

\footnotetext{
${ }^{214}$ Declarações de Rodrigo Hinzpeter disponíveis em: shorturl.at/pwAIg. Acessado em: 05/07/2017.
} 
Adriana que era um dos voluntários incumbidos de levar comida para ela ${ }^{215} \mathrm{e}$ que sempre nos esperava para saber como tinha sido a sessão. Dessa vez, no entanto, ele estava agitado. Um homem sentado no corredor havia tirado uma foto dele - ou, pelo menos, assim ele achava. O homem continuava sentado, mexendo no celular. Perguntamos se alguém o conhecia. Ele tinha cerca de 40 anos, cabelo curto, e estava vestido com roupa casual, calça jeans, camiseta e boné. Ante a negativa, e vendo que ele estava muito próximo de nós, decidi me aproximar. Perguntei se podia ajudá-lo de alguma forma, se era amigo de algum dos jovens e que nos chamava a atenção a sua presença naquele local, porque, no geral, só amigos e parentes circulavam durante as audiências. $\mathrm{O}$ homem não me respondia, tampouco olhava para mim; se fazia de desentendido enquanto continuava mexendo em seu celular. Quando todos começamos a olhar para ele, finalmente, foi embora. Uma das advogadas da ONG Defensoria Popular, que testemunhou a situação, falou que era muito comum que policiais à paisana fizessem isso, a fim de intimidar parentes e amigos para que se sentissem alvos de vigilância e controle.

No caso da mãe de Rosa, ela comentou outros episódios estranhos, de carros que seguiam ela perto de sua casa. Ademais, todos os pais dos jovens acusados acreditavam que seus telefones haviam sido grampeados pela polícia. A mãe de Adriana, inclusive, cada vez que me encontrava durante as visitas na prisão, comentava nervosa a propósito dos ruídos que ouvia quando usava o aparelho celular, bem como de ligações estranhas. Se tudo isso era fato ou não, o mais interessante me parece pensar nos efeitos dessa ameaça imaginada, intangível, porém sempre constante; essa sensação de estar sendo vigiado sem que se perceba por um espectro fantasmagórico, um outro onipresente: o Estado e seus informantes.

A terceira experiência foi na saída do Centro de Justiça de Santiago. Ás vezes, um pequeno grupo de jovens se reunia na frente do prédio com cartazes que pediam a liberação dos presos políticos, inclusive Adriana. Em um desses dias, me chamaram para entregar um dinheiro que haviam

\footnotetext{
215 A Gendarmeria do Chile não alimenta os réus fora das instalações carcerárias. Assim, entre parentes e amigos, nós sempre organizávamos alguma coisa para que os jovens pudessem almoçar depois das sessões, já que a espera até serem levados de volta à prisão podia demorar horas.
} 
coletado para ajudar a pagar a alimentação de Adriana. Agradeci o gesto de solidariedade e, em seguida, um pai de um dos jovens me apresenta um homem de uns 40 anos, vestido de calça jeans e camiseta: "este aqui é nosso companheiro argentino". Era o único adulto entre os jovens e se comportava como uma liderança meio deslocada. Começamos a falar dos avanços nos julgamentos, das evidências da ADN e das declarações dos peritos; depois disso, ele me perguntou se eu gostaria de conversar um pouco mais. Trocamos telefones (ele com um número argentino, e eu com meu número brasileiro) e marcamos por Whatsapp para o dia seguinte em uma lanchonete no centro de Santiago. Sentados frente à frente, ele quis ouvir sobre a minha pesquisa de doutorado, o que havia me motivado a trabalhar com isso e o que pretendia fazer com as informações colhidas durante o trabalho de campo.Com calma, fui explicando para ele sobre o meu trabalho. De qualquer maneira, aquela não foi a primeira vez em que eu era vista com suspeita.

Porém, de um momento a outro, ele começou a falar de sua militância em uma rede trotskista internacional, de viagens pela América Latina, tudo de modo abstrato. E de repente ele me conta de uma viagem até a Síria, o que me deixou um tanto quanto pasmada. Insinuou que teria participado na luta junto com os curdos. Eu o ouvia com atenção, enquanto discorria sobre a geopolítica mundial durante mais de uma hora, em um monólogo excessivo e exaustivo. Entretanto, o que me pareceu mais estranho foi a forma como me falou dos jovens que estavam com ele no dia anterior, no Centro de Justiça. Dizia que eram moleques que nada sabiam da vida e que ele se dedicava a circular por várias faculdades de Santiago organizando outros jovens. Nunca mais me contatou, e eu nunca mais o vi no Centro de Justiça.

Quando Adriana e Rosa foram finalmente liberadas, eu me lembrei desse homem e perguntei a elas se sabiam de algo a respeito dele. Não o conheciam. Quem era ele? Nunca soube. Contudo, para Adriana e Rosa, era muito óbvio: nada mais podia ser que um "sapo".

\section{Ideologias encarnadas}

Como tantas coisas que aprendi nestes anos olhando nas ruas e nas paredes de Santiago, foi no caminho para uma das tantas audiências que assisti no Centro de Justiça de Santiago, acompanhando o julgamento de 
Adriana, que vi o rosto de Antonio Ramón pela vez primeira. Em um cantinho daquele tumultuado bairro ao redor do Centro de Justiça de Santiago, entre os camelôs e a correria das pessoas, havia uma pedra branca descuidadamente disposta no chão; nela, tinha gravada a sua imagem junto a uma mensagem: "O vingador do povo". Sem saber de quem se tratava este justiceiro popular, o Google me deu uma resposta e uma supressa: faz um século, esse homem de origem espanhola tinha sido acusado de perpetrar um atentado anarquista. Em 1914, Antonio Ramón foi pego pela polícia quando, em plena luz do dia e com uma faca, atacou o general do Exército, Roberto Silva Renard, há poucos quarteirões de distância de onde, hoje, está situado a pedra à sua memória. Ainda que o homem não tenha declarou militância quando interrogado, falou-se em anarquismo por um suposto livro que a polícia teria achado no cortiço miserável onde morava na periferia (Sánchez, 2014; Goicovic, 2005).

Naqueles anos, a perseguição política e o encarceramento de anarquistas em Santiago faziam parte do trabalho policial (Grez, 2007). A participação em greves operárias, publicação de jornais e organização de grupos de estudos estavam entre as ações mais recorrentes dos anarquistas da época (Del Solar; Pérez, 20o8). A eles, no entanto, atribuíam-se responsabilidades em outros episódios, como roubos a bancos e ataques a igrejas, que, aos olhos da elite e da imprensa, não podiam ser mais que atentados anarquistas, tal como os que aconteciam na Europa. A animadversão pública pelo anarquismo, definida como ameaça estrangeira, chegou a seu paroxismo como o caso de Antonio Ramón:

É um miserável corrompido pela predicação anarquista feita no norte do país por elementos estrangeiros; ele foi permitido de entrar sem qualquer critério aqui e esfaqueou covardemente um general da República, um bom homem que cumpria com o seu dever (El Mercurio, 15/12/1914) $)^{216}$

A respeito da bondade da vítima, entretanto, podemos discordar. O general Silva Renard foi quem deu a ordem, no dia 21 de dezembro de 1907, de disparar contra uma multidão de trabalhadores do salitre na cidade de

\footnotetext{
216 "Anarquismo y violencia popular en Chile 1898-1927". Disponível em: https://bit.ly/ 2ZpwToQ. Acessado: 22/o9/2918
} 
Iquique, evento conhecido como La Matanza de la Escuela Santa María217. Estimam-se que foram assassinadas entre 200 e 400 pessoas, incluindo as esposas e os filhos dos operários em greve. Entre os mortos, diz a história popular, estava o irmão de Antonio Ramón. Para chegar a essa verdade, Antonio teria cruzado a pé a cordilheira dos Andes, desde a Argentina, na busca de seu parente, de quem não ouvia notícias há meses, chegando até o norte do país para descobrir o destino fatal do irmão. Entre os historiadores, é necessário dizer que há discrepâncias sobre o sentido do ataque, se foi um mero ato de vingança pessoal ou de ajusticiamiento popular (Goicovic, 2005).

A repulsa pública pelo anarquismo excedia o Chile. Naqueles anos, processos judiciais contra anarquistas ocorriam na Argentina, no Brasil e no Uruguai - países onde estavam se discutindo leis migratórias e que, entre outros assuntos, pretendiam barrar a chegada de "agitadores anarquistas" no Cone Sul. As redes anarquistas, assim como as anti-anarquistas, proliferavam em escala transnacional. Estas últimas, incluíam o compartilhamento de dados de inteligência entre unidades policiais de Buenos Aires, Santiago e Rio de Janeiro (Albornoz; 2017; Albornoz; Galeano, 2017; Hernández; Salazar, 1994). Em seminários e convenções policiais, ainda, discutiam-se as definições do que era o anarquismo e os alcances dessa ideologia na sociedade, delito político que os especialistas da polícia equiparavam a crimes migratórios, como o tráfico de mulheres e a "vagabundagem". O Comissário de Investigações de Buenos Aires, José Rossi, que palestrou no primeiro encontro internacional de polícias, em 1905, na capital argentina, asseverava acerca dos anarquistas: "são uma seita de indivíduos partidários de doutrinas francamente antissociais que buscam, conforme dizem eles próprios, mudar a organização atual utilizando-se de todos os recursos subversivos e terríficos, propagando a desordem, o roubo e o assassinato (apud, Hernández; Salazar, 1994, p. 88).

Na Europa, poucos anos antes, aconteceu o maior evento de coordenação internacional anti-anarquista, a Conferência de Roma, de 1989,

\footnotetext{
217 Recomendo o disco La Cantata de Santa María de Iquique (1970) do grupo Quilapayún, uma das obras mais importantes do gênero musucal, o Canto Nuevo chileno, e que retrata esse trágico evento.
} 
organizada logo após do assassinato da Imperatriz da Áustria, reunião da qual participaram representantes de mais de 20 países e que prefigurou a futura Interpol (Jensen, 1981). A figura do anarquista-que-arma-bombas transformou-se no outro radical, monstruoso, imprevisível, viciado na violência que aterrava o continente europeu - e o nosso também (Eisenzweig, 2004; Echezarreta, 2015).

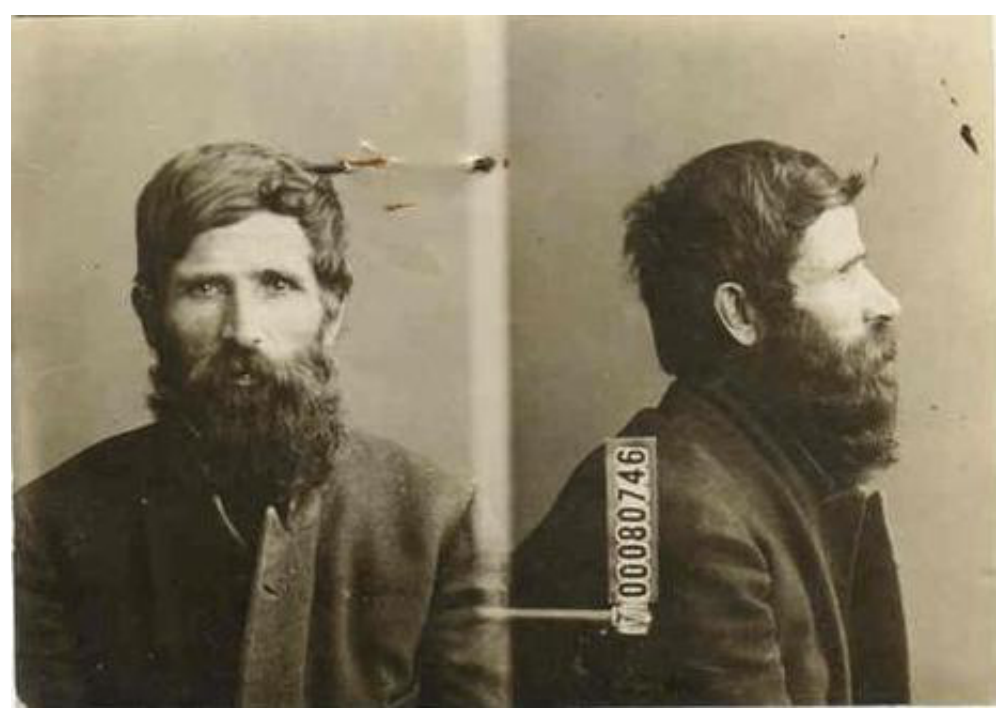

Figura 21: Retrato policial de Antonio Ramón (Wikipedia)

Voltando a Antonio Ramón, no momento de ingressar como acusado na Penitenciária de Santiago, seu rosto foi capturado pela lente fotográfica. Essa imagem é a que chega até nós, no presente. Nesses anos, depois de intensos debates técnicos, o Chile incorporou o protocolo de registro fotográfico dos internos no sistema penitenciário, seguindo para tanto o cânon do retrato policial: olhar de frente, de perfil, sem expressão no rosto (León, 1999). O juiz, ainda, ordenou pericias antropométricas no corpo suspeito, prática comum nos primórdios evolucionistas da antropologia criminal. Seguindo a hipótese do eugenista Cesare Lombroso, esses exames pretendiam a possível identificação de "estigmas degenerativos" (Sánchez, 2014). Como é sabido, o pai da antropologia criminal defendia que era possível identificar delinquentes por meio de uma série de traços físicos - e 
não só assassinos e ladrões ${ }^{218}$. Na proposta de Lombroso, a criminalidade, fosse política ou não, podia ser lida no próprio corpo do suspeito: os traços desarmônicos eram evidência de inferioridade moral, da predisposição criminal ou, ainda, de ideologias subversiva. O afamado Ravachol (François Claudius Koënigstein), condenado a morrer na guilhotina por explodir um restaurante em Paris, em 1892, era exemplo, assegurava Lombroso, de um rosto assimétrico típico que revelava a brutalidade do pensamento anarquista, propenso à violência cega e indiscriminada ${ }^{219}$.

Os médicos encarregados de examinar Antonio Ramón identificaram estigmas degenerativos, tais como o crânio aplastado e protuberâncias occipitais anormais; no entanto, concluíram que não eram suficientes para afirmar predisposição anarquista no indivíduo estudado (Sánchez, 2014, p. 395). Finalmente, prevaleceu o diagnóstico psicológico: Antonio Ramón passava por um estado mental patológico causado pela morte de seu irmão (Ibid., p. 394). Portanto, não houve evidência médica nem policial que confirmasse a tese de que o ataque obedeceu a uma suposta doutrina anarquista. Finalmente, foi declarado inimputável e liberado. Antonio Ramón foi embora do Chile sem nunca mais retornar ${ }^{220}$.

$218 \mathrm{Um}$ par de anos antes da conferência internacional anti-anarquista, em Roma, Lombroso publicou Gli Anarchici (1895), pesquisa que incluiu a comparação de retratos de "criminosos políticos” na Itália e nos Estados Unidos, trabalho em que concluía a predominância de assimetrias faciais entre os presos anarquistas.

219 É de se notar que Lombroso, homem da ciência, republicano, anti-clerical, com breve militância no Partido Socialista, faz uma revisão das teorias anarquistas no seu livro e diferencia entre os anarquistas que colocam bombas e os teóricos anarquistas, como Kropotkin, cujas proposições eram razoáveis à luz das injustiças sofridas pelos pobres. A título de curiosidade, no livro, ele louvava os belos traços do rosto de Karl Marx (Lombroso, 1895).

220 Recomendo o documentário de Ximena Salazar, La Venganza de Ramón (2007). Disponível em: https://bit.ly/2ZaiLaO. Acessado em: 06/o6/2017. 


\section{Sociólogos peritos}

Todos temos nosso próprio doppelgänger ${ }^{221}$. Entre os diversos documentos inclúdos no dossiê do inquérito policial contra os jovens da okupa, há um relatório escrito por um doutor em sociologia, Erik Marin ${ }^{222}$. O texto "Análise Pericial do Caso Bombas" discorria acerca da história do anarquismo desde o século XIX até chegar no século XXI e a irrupção da corrente insurrecional-niilista, em países como Itália, Grécia, Espanha e, por certo, Chile. Para tanto, citava publicações acadêmicas de diversas índoles, incluindo os trabalhos de David Graeber e Jeffrey Juris (tal como eu, no capítulo 2), construindo os antecedentes que permitiram compreender a ação de redes clandestinas e anônimas que, por meio de comunicados, assumiram em redes sociais a autoria de ataques de baixa intensidade contra símbolos o Estado e o Capital.

A análise do sociólogo foi fundamental para a persecução criminal dos imputados. Marin construiu a "Rede Total": uma lista de 189 pessoas suspeitas. No informe, havia nome e sobrenome de indivíduos, supostamente vinculados entre si por laços de amizade, afetivos e até consanguíneos, e que conforme dados proporcionados pela polícia frequentavam o "ambiente anarquista”: desde atividades em okupas até shows de música punk. Como já vimos, desde a morte de Morales, as polícias começaram a vigiar esses espaços. A lista pouco se diferencia de uma convencional "lista negra" de perseguição política: em ordem correlativa, aparecem nomes de visitantes de presos políticos, músicos, cientistas sociais ${ }^{223}$, militantes de organização de defesa animal, ex-presos políticos, entre outros. A grande contribuição da perícia, no entanto, dizia relação à análise dita científica dos laços entre esses suspeitos realizada por meio de um software de análise de redes sociais.

${ }^{221}$ Monstro ou ser fantástico que tem o dom de representar uma cópia idêntica de uma pessoa que ele escolhe ou que passa a acompanhar, o que hipoteticamente pode significar que cada pessoa tem o seu próprio duplo.

222 Psicólogo da Universidade Central no Chile, diplomado na Academia Nacional de Estudos Políticos e Estratégicos (ANEPE) do Ministério de Defesa do Chile e pós-graduado em sociologia na Universidade de Granada, na Espanha. Tem trabalhado para a Gendarmeria do Chile e os Carabineros do Chile.

${ }_{223} \mathrm{Na}$ lista, estava Gabriela Barría, historiadora cujo trabalho sobre Eduardo e Rafael Toledo citei no Capítulo 2. 


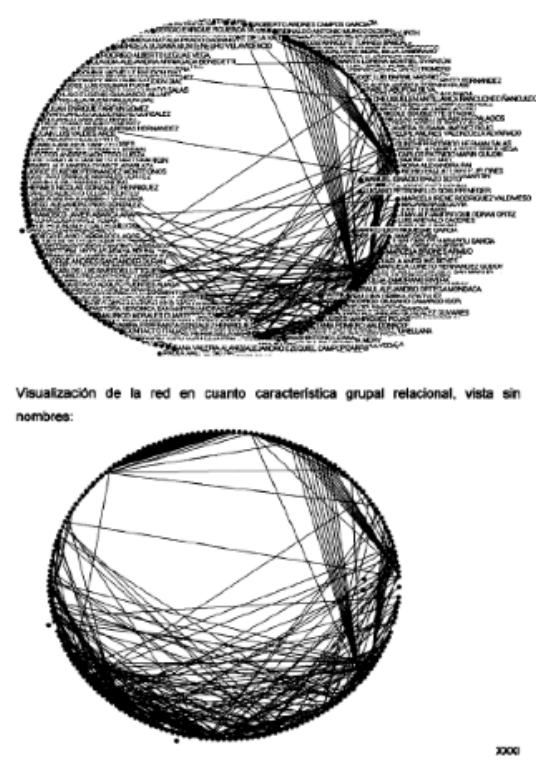

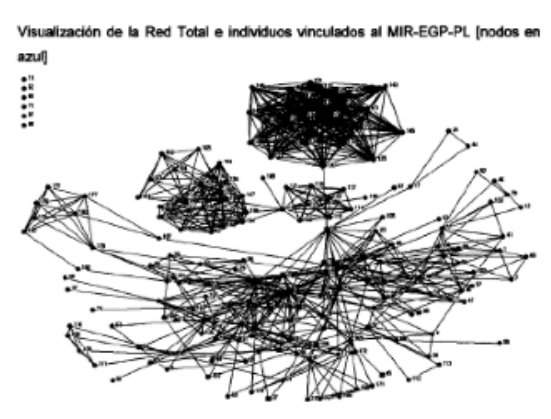

Figura 21 e 22:

Análise Erick Marin (2010)

Trata-se de uma série de diagramas atrativos (Fig. 21 e 22) que pretendiam plasmar visualmente as formas em que os suspeitos se vinculavam, identificando um círculo de pessoas que seriam os responsáveis dos ataques "não convencionais" (termo caro ao campo securitário atual), a saber, os 14 imputados pelo caso. Por certo, como podem imaginar, na rede estava incluído o falecido Mauricio Morales, o anarquista decepado. A conexão estabelecida pelo informe, além dos tipos de laços, pretendia situar aqueles interconectados por uma ideologia comum: o anarquismo insurrecional.

Da lista e da rede, o analista logo depois passava a descrever uma outra figura: as "células". Assim como aconteceria com grupos anarquistas no exterior, os ataques no Chile seriam perpetrados por pequenos grupos clandestinos de até 3 pessoas que operariam de modo independente, usando principalmente "Artefatos Explosivos Improvisados" (outro termo do campo da guerra) para atacar o Estado. Isto, com o objetivo, argumentava o perito, de difundir sua ideologia por meio do terror. Para a persecução criminal, tal conclusão foi fundamental: a rede desenhada pelo sociólogo foi traduzida na figura penal da "associação ilícita" com o agravante do terrorismo. O informe, de fato, foi um dos antecedente estratégicos do Ministério Público para incriminar jovens suspeitos. Porém, as críticas às metodologias utilizadas, bem como a elaboração um tanto arbitrária dos argumentos, não só se 
proliferaram nos circuitos libertários (que tiveram acesso, assim como eu, pelo vazamento em redes sociais do documento). Um dos juízes da causa descartou o relatório como evidência: foi considerado "sociologia barata" pelo magistrado 224 .

As redes e tramas, fios e suspeitas plasmadas nos curiosos desenhos de Marin eram a representação gráfica das fantasias conspiratórias das polícias, onde tudo se conectava entre si: "e assim, do nada, por falar oi para alguém, por ir na casa de alguém, até por ir a uma tokata, você acabava sendo parte de uma organização terrorista" (Guerra, 2015, p. 75) - criticavam as pessoas que apareceriam na lista negra. Fantasia, no entanto, com consequências muito concretas: os acusados estiveram meses em prisão provisória, e aqueles que não foram detidos, mas que apareciam na lista, passaram a se sentir vigiados e receosos o tempo todo. $\mathrm{O}$ poder da espionagem policial não é passar totalmente desapercebido: é "encenação da presença como ausência” (L'Heuillet, 2004, p. 53).

Por outro lado, resulta notável o seguinte paradoxo: as redes construídas pelo sociólogo, como todo diagrama, são uma metáfora visual que pretendia sintetizar e objetivar um conhecimento imparcial. É curioso pensar como essa neutralidade das redes sofisticadas são produzidas por meio de um software, e que resultam visualmente sedutoras justamente porque elas parecem algo científico; entanto, elas são construídas com base em informações coletadas por agentes policiais à paisana, que circundavam espaços de sociabilidade política e cultural suspeitas aos olhos do Estado por serem anticapitalistas e, sobretudo, Anti-Estado.

O olhar do sociólogo, o olhar do policial: a caçaria de corpos por meio de corpos, que, logo depois, são descarnados na análise de redes, traduzidos por um traço e algumas variáveis. A análise de redes, aliás, é uma das metodologias de pesquisa mais valoradas no campo da contra-insurgência contemporânea, sob a suposição de que as dinâmicas de "radicalização"

224 Ditos do magistrado Luis Avilés disponíveis em: https://bit.ly/2ZrKPX1. Acessado em: $11 / 03 / 2018$. 
operam pela difusão de ideologias radicais mediante vínculos de parentesco e amizade 225 .

Marin não seria o único sociólogo na luta contra o anarquismo insurrecional. No inquérito feito pela explosão sobre o atentado à estação de metrô, em 2014, entre os peritos convocados pelo Ministério Público, estava Cristian Darville226, sociólogo pós-graduado na Universidade de Southern California, com especialização em Crime Organizado Transnacional na academia militar George C. Marshall European - Center for Security Studies.

O seu informe pericial teve mais sucesso e foi incorporado no julgamento, tendo ele próprio participado como testemunha no caso, respondendo no estrado às consultas do promotor e dos advogados de defensa. Em vez de análise de rede, o profissional se apresentou como especialista em análise de discursos e de ideologias. O material empírico que utilizou para seu informe incluía comunicados anônimos divulgados em redes sociais que assumiam a responsabilidade dos ataques explosivos, assinados por acrônimos que ele equiparava a grupos e/ou organizações. Da análise desse corpus linguístico, o perito descrevia a ideologia anarquista insurrecional com o objetivo de determinar as semelhanças entre os ataques explosivos investigados no caso com as atividades perpetradas no exterior por grupos que usavam os mesmos nomes no momento de assinar os comunicados nos quais assumiam a autoria dos ataques, a saber, a Conspiração Internacional pela Vingança e a Conspiração das Células do Fogo.

Nesse sentido, pretendia-se examinar o caráter transnacional das redes clandestina de anarquismo insurrecional e constatar semelhança no modus

225 A bibliografia sobre análise de redes de radicalismo é enorme, especialmente para entender porque pessoas que moram no primeiro mundo se solidarizariam e participariam de atividades "terroristas". Para uma critica excelente do conceito de radicalismo nas políticas de segurança interna dos Estados Unidos e da Inglaterra, recomendo fortemente o livro The Muslims are Coming! Islamophobia, Extremism, and the Domestic War on Terror, de Arun Kundnani (2016). Para um estado da arte do conceito no campo dos estudos de movimentos sociais, sugiro o artigo "Radicalization: a relational perspective", da socióloga italiana Donatella Della Porta (2018).

226 Atualmente, trabalha como assessor do Ministério Público; além de reportar sobre o anarquismo insurrecional, desde 2018, o sociólogo é especialista em "violência rural", como é chamado o conflito pela recuperação de terras indígenas mapuches no sul do Chile. 
operandi entre os ataques no Chile e em outros países, como Itália e Grécia. Para entender melhor a dinâmica dessas "organizações", o sociólogo apresentou aos magistrados o que ele chamou de "modelo de replicação de células": um grupo pequeno realiza um ataque e reivindica a ação pelas redes sociais usando o nome de algum desses grupos internacionais. É por meio da ação destrutiva que se passa a fazer parte da organização, e não por uma militância formal, já que não existem partidos, nem afiliações, tampouco encontros sistemáticos entre os seus integrantes.

Uma grande diferença nesse julgamento foi a decisão do Ministério Público de desistir de falar de "associação ilícita”. Em parte, por aquilo que argumentado pela perícia sociológica: quando há uma organização para além de células, há um grupo de afinidades que se define como "sistema autossuficiente, horizontal, inorgânico, adaptável e flexível”227. Como poderiam grupos de afinidades conformar quadrilhas, com chefes e estrutura hierárquica?

Assim sendo o delito seria terrorista pela intenção do ataque de disseminar o terror entre a população, portanto, depende das circunstâncias do atentado: lugar, local, métodos. Uma bomba no meio do metrô do dia, não podia ser mais que a intenção de causar terror. Um dos jovens imputados foi condenado por crime terrorista a 23 anos de prisão - a primeira por esse crime desde implementada a Reforma Processual Penal228.

227 Os grupos de afinidades são a estrutura organizacional característica do anarquismo: unidades militantes autônomas, de 5 a 25 indivíduos, que decidem os tipos de ações nos quais se envolvem por meio de processos de decisão deliberativos e consensuais. Essa forma de organização tem sido utilizada por militantes anti-autoritários no movimentos alterglobalização (Dupuis-Déri, 2010).

228 A Reforma Processual Penal foi iniciada em 200o, e marcou no Chile a passagem de um sistema penal inquisitivo, secreto e baseado no escrito, para um sistema acusatório e oral que se autodescreve como eficiente, rápido, transparente, imparcial e acessível a todos e todas: um sistema moderno ad hoc aos critérios internacionais, garantindo direitos tanto das vítimas como dos acusados. Uma das maiores transformações diz respeito à divisão de tarefas: no sistema anterior, o poder judiciário, além de julgar, envolvia-se na fase de acusação, produção de prova e investigação. Essas funções agora passaram a ser responsabilidade de uma nova entidade, o Ministério Público (chamada também de Fiscalía) - organismo autônomo que não faz parte de nenhum dos três poderes do Estado. Também se criou a Defensoria Penal Pública, instituição dependente do Ministério de Justiça que deve prover defesa gratuita aos acusados que não tiverem acesso a um advogado particular. 
Na sua análise, Darville concluía que, embora não fosse possível creditar ou descartar que os imputados "comungavam" com grupos anarquistas insurrecionais internacionais, era plausível dizer que de fato eram anarquistas. O promotor do Ministério Público, no último dia de um julgamento que durou quase 8 meses, remarcava a evidente viés ideológico dos suspeitos, pela "iconografia" estampada em uma série de evidências materiais colhidas. Mensagens, símbolos e desenhos escritos nas paredes de seus quartos, nas ruas dos bairros onde moravam, frases tais com "presxs a la kalle", "a destruição é o único modo de ser livre", "destruir o Estado, construir a Anarquia”, destacando que os A eram sempre substituídos por A em um círculo. Também, o momento da detenção dos suspeitos confirmaria a ideologia professada por eles, no instante de gritar para as câmeras: "Chega do Estado Policial”. Por fim, o próprio corpo de um dos suspeitos seria lugar de inscrição ideológica:

Em seus antebraços, a esquerda, em francês, a frase "Assez longtemps geindre et soufrir" [tempo sufciciente para chorar e sofrer] que foi tirada da música La Ravachole, criada em comemoração e lembrança do anarquista francês François Claudius Koënigstein, conhecido como Ravachol e que foi condenado à morte pela colocação de artefatos explosivos e pelos mortos (Condenação "Caso Metrô" Sexto Tribunal Oral en lo Penal de Santiago, 2018, p.78).

Neste julgamento, porém, assim como no Caso Bombas e no de Adriana, que irei analisar nas páginas seguintes, os juízes insistiram que não se tratava de condenar ideologias: o que importava era determinar os culpáveis das explosões. O Direito Penal Moderno é um direito penal de fatos - explicava uma das magistradas no caso do metrô. Ainda mais: mesmo que fosse comprovado a adscrição dos suspeitos ao anarquismo, o Código Penal chileno não estabelece que, para supor que um delito seja tido como terrorista, devam ser identificadas ideologias específicas: "El mero pensamiento sin exteriorización no incumbe al Derecho Penal" (Condenação "Caso Metrô" Sexto Tribunal Oral en lo Penal de Santiago, 2018, p. 1743). Porém, em todos eles, se tem investido energia e tempo em descrever ideologias anarquistas, as suas diferenças e os processos de conformação histórica. Além dos peritos e dos sociólogos especialistas em anarquistas, os policias das unidades de inteligência também testemunharam acerca do 
anarquismo e das evidências que demonstrariam as ideologias seguidas pelos suspeitos.

O investimento das policias chilenas em se aperfeiçoarem na luta contra o anarquismo traduz-se em uma série de seminários e eventos onde são convidados pares de instituições policiais europeias especializados no assunto. Fluxos de conhecimento que, de um lado, situam o anarquismo sob a categoria de crime organizado transnacional. Especialistas espanhóis em "violência antissistema" palestraram sobre o anarquismo para funcionários da Fuerza de Tarea de Delitos Complejos da Policía de Investigaciones do Chile, em 2014, evento o qual os participantes chilenos comentavam ser uma excelente oportunidade para aprimorar o trabalho científico, pericial e analítico na perseguição dos suspeitos, assim como na compreensão da ideologia anarquista insurrecional e sua conformação histórica (Revista El Detective, $\mathrm{N}^{\mathrm{o}} 163,2 \mathrm{O} 14$, p. 32-35).

No mesmo ano, a outra força policial chilena, a Direção Nacional de Inteligência, Drogas e Investigação Criminal, recebeu especialistas da Itália e Grécia (Revista Carabineros, 2014, Edição 716, p. 17-18). Em 2017, Manuel Leiva, chefe nacional de Inteligência da Polícia de Investigaciones do Chile (PDI), comemorou a sua escolha como presidente da Comunidade LatinoAmericana e do Caribe de Inteligência Policial (CLACIP), empreitada regional para enfrentar as ameaças contemporâneas, entre elas o narcotráfico, o crime cibernético, o fundamentalismo religioso - e o anarquismo (Revista El Detective, $\mathrm{N}^{\mathrm{o}} 171,2017$, p. 32).

Que os especialistas trazidos para ensinar os policiais chilenos sejam europeus, não é por acaso. Desde o 2007, o "terrorismo anarquista" é monitorado pelo Serviço Europeu de Polícia (Europol) junto ao terrorismo jihadista229, o terrorismo separatista e o etno-nacionalista, o terrorismo de direita e o terrorismo individual230. O reporte Terrorism Situation and Trend Report (TE SAT) da Europol ano a ano, compara o número de ataques ditos anarquistas nos quais se daria o uso preferencial de coquetéis Molotov e dispositivos explosivos improvisados (IED), táticas pouco sofisticadas e que não requerem treinamento ou preparação. No relatório, deste ano, 2019,

229 Nos primeiros relatórios, chamava-se de "terrorismo islamista”.

230 Categoria incorporada nos últimos três relatórios. 
destacava-se entre as justificativas para os atos violentos a denúncia de problemas sociais, as escaramuças com a polícia em protestos e a solidariedade para com “terroristas presos". A Internet é meio para reivindicar ações, divulgar ideias e ampliar a escala internacional de atividades. O reporte da Europol, ainda, alertava que extremistas anarquistas são mais violentos que os de extrema esquerda e representam um sério risco para a maioria dos Estados da União Europeia.

\section{Sala 307}

É a primeira audiência do julgamento contra Adriana, Rosa e os outros três jovens que foram acusados de ataque incendiário contra uma delegacia da polícia. O Ministério Público está pedindo 15 anos de condenação por tentativa de homicídio. A sala é simples, porém solene: construída de madeira e concreto, sem adornos para além de uma bandeira do Chile e um relógio de parede. Não há janelas. Tudo parece muito limpo e reluzente. O prédio de justiça tem pouco mais de 10 anos. O elemento central da sala é o estrado dos juízes, situado em um nível mais alto das outras peças do mobiliário. Às 9 h, nós, os parentes, já estamos todos sentados na área da sala que nos foi designada. É a primeira vez que entro em uma sessão judicial. Inclusive, conheço os parentes dos outros imputados: mães, pais, irmãs. Por razões de segurança, a Gendarmeria do Chile, que cuida do Centro de Justiça de Santiago, decretou que só podiam entrar duas pessoas por imputado, necessariamente parentes ou amigos, com prévio cadastro.

Também é a primeira vez que vejo pessoas sobre as quais falei há alguns meses com Adriana nas visitas na prisão: o Promotor do Ministério Público, o advogado que representa a Policía de Investigaciones de Chile, os agentes que sofreram lesões no ataque (ranhuras e um corte de menos de 1 $\mathrm{cm}$, conforme o laudo médico) e a advogada da Intendência da Região Metropolitana de Santiago 231 . Da mesma forma é a pela primeira vez que tenho contato com os advogados de defensa, as duas advogadas da Defensoria Penal Pública que representam Adriana e Rosa, e os três

${ }^{231}$ Esta instituição se somou ao Ministério Público e, nos últimos protestos de rua, tem assumido papel ativo na persecução criminal a suspeitos de terem participado, mascarados, da destruição de bens no ínterim dos protestos. 
advogados da ONG Defensoria Popular. Nenhum dos acusadores nem defensores ultrapassa os 50 anos.

Entram os imputados: Adriana, Rosa e outros três jovens, todos algemados nos pés e nas mãos, vestidos de coletes amarelos e com um guarda penitenciário da unidade tática acompanhando cada um deles. Como expliquei anteriormente, na classificação da Gendarmeria do Chile, eles são tratados de réus de alto risco. Já quando estamos todos sentados, ingressam os juízes: automaticamente, os advogados (e alguns poucos parentes) se levantam em gesto de respeito. O Tribunal é composto de três mulheres e um homem. Uma delas é a presidente da mesa ("la magistrado"), outra, a redatora, e o restante atua de suplente, ainda que participe de todas as sessões. Duas delas não ultrapassam os 40 anos, e os outros dois possuem cerca de 55 anos. Terminada a apresentação de cada um dos intervenientes, processo de muita formalidade no qual os advogados e os acusados indicam em voz alta os seus nomes, endereços, dados de identidade, dá-se finalmente início à primeira sessão do julgamento.

Vestido de terno, impecável, cabelo curto já grisalho, o Promotor está cercado de objetos: computador portátil, o volumoso dossiê do caso que soma mais de mil páginas, muitas delas abarrotadas de post-it, laudos, cópias do Código Penal, canetas, marcadores de diferentes cores. No chão, estão as malas com rodinhas repletas de evidências (bitucas de cigarro, camisetas, panfletos, cartas, entre muitas outras coisas) que serão exibidas no transcurso do julgamento. Com voz forte e usando variações na entonação, o Promotor inicia a acusação, lendo um trecho:

No dia, 13 de agosto de 2014, aproximadamente às 13h3o, os réus, juntamente com outros sujeitos não identificados, passaram da sede da Universidade X, para a sede da Brigada de Homicídios da Polícia de Investigações do Chile, vestidos com roupas anticorrosivas e carregando vários dispositivos incendiários. Seguidamente, eles trancaram o portão com correntes, impedindo que os funcionários saíssem. Depois disso, os dispositivos incendiários acima mencionados foram lançados desde a via pública para o prédio mencionado e para dentro de um veículo estacionado a poucos metros da porta. Da mesma forma, eles também lançaram os ditos dispositivos incendiários para outros veículos estacionados dentro do recinto da polícia, causando um incêndio, um perigo para a vida e a integridade daqueles que estavam lá, como também daqueles que estavam em sua vizinhança. Logo depois, para fugir, entraram na sede 
educacional recentemente mencionada (Condenação "Caso Adriana”).

O relato inicial do Promotor sobre o ataque durou menos de 2 minutos. Trata-se de uma história embasada na investigação feita durante oito meses em sigilo pela Policía de Investigaciones do Chile, inquérito dirigido pelo Ministério Público e que se iniciou imediatamente após o ataque232. Uma equipe policial multidisciplinar, composta de especialistas em bioquímica, planimetria, fotografia, entre outras áreas, tiveram como tarefa coletar provas da cena do crime. Restos de garrafas quebradas e pedaços de tela com combustível foram recuperadas da rua. Na universidade, em lixeiras, acharam-se uma série de roupas que teriam utilizado os atacantes: mais de trinta pares de luvas, dezenas de camisetas e meias, macacões tyvek e muitas sacolas plásticas, entre elas, as que envolviam as roupas anticorrosivas. Cada um dos objetos foi exibido no estrado ("exhibición de medios de prueba"), processo demorado e muito protocolar.

Os policiais também consideraram como provas outra classe de objetos bem diferentes, coletados da universidade, local de onde os atacantes teriam fugido: faixas pela educação pública, um par de cartazes do MIR e, inclusive, um copo plástico de café com o "símbolo ácrata”. Fotografaram paredes de uma sala de aula grafitadas com mensagens que chamaram de anárquicas: "Fogo na polícia" e "Claudia López, Presente". Nesse local, que é um centro de estudantes, reuniam-se os "encapuchados" nos dias protestos, pelo menos isso era o que os policiais asseguravam. Sobre o cartaz do MIR, imagem que circulou nos telejornais para falar do caso, um dos policiais que participou do levantamento de evidências respondeu aos defensores: "é um movimento criado faz muitos anos, um movimento revolucionário no país". Portanto, se os primeiros objetos eram superfícies materiais das quais, por

\footnotetext{
232 Trata-se do que Pastore (2007) chama de uma "história bem contada", uma história que é apresentada como se não houvessem cabos soltos, mesmo que essa história se fundamente em uma miríade de informações desconexas entregues por testemunhas, laudos e provas de todo tipo (objetos, filmagens, fotos, DNA). Isso se encaixa no gênero discursivo das acusações, forma de produção linguística (verbal e escrita) de conteúdo e de recursos característicos que são utilizados e reconhecidos pela comunidade jurídica que atua em litígios (Agüero, 2014).
} 
meio de técnicas científicas, podiam ser detectados restos orgânicos dos autores, os segundos, para os policiais, eram parafernálias políticas que dariam conta da ideologia dos réus, assim como os livros sobre marxismo, anarquismo e história da ditadura que foram coletados das casas dos jovens no operativo policial de detenção, além de roupas de bandas punk ${ }^{233}$.

Os especialistas do Laboratório de Criminalística Central (LACRIM) da Policía de Investigaciones234 conseguiram encontrar uma impressão digital em uma das sacolas plásticas colhidas na universidade. Depois de ser escaneada, quer dizer, depois dos restos orgânicos terem sido transformados em informação digital, o material foi analisado com o AFIS (Automatic Fingerprint Identification System), sistema que efetua comparações automatizadas usando bases de dados da polícia. O software entrega uma lista de "candidatos" e, posteriormente, o perito em bioquímica, utilizando seus olhos, vai comparando as digitais até achar a imagem com mais pontos de coincidência. "Deu match" - diz ela no estrado, enquanto explica como elaborou o seu relatório: não é um processo automatizado, como ela tenta descrever, se não algo que depende da sua interpretação. Em uma grande tela, eram exibidas as imagens das digitais, indicando os pontos de coincidência aos juízes. Domínio jurídico perpassado pela ciência.

\footnotetext{
233 No caso de Adriana, vários meses depois de ser absolvida, finalmente ela conseguiu recuperar os pertences que a polícia havia levado de seu quarto como supostas evidências: fotografias pessoais, ingressos de shows musicais, cartazes colados no quarto sobre política e até um pequeno pedaço de tela onde se lia "A.C.A.B", junto à imagem de um gato. "Os pacos devem ter achado que se tratava de 'All Cops Are Bastards' - frase corriqueira no mundo do punk. Mas, daquela vez, era um outro acrônimo: "All Cats Are Cutes". Ainda que possa parecer um disparate, em 2016, na Espanha, uma jovem foi multada pela polícia por usar uma bolsa que levava as mesmas letras, acusada de carregar um objeto com símbolos que conotavam um ataque à autoridade.

234 Fundado em 1935, com a missão de apoiar a polícia no esclarecimento de crimes, conforme diz o relato institucional, mediante a aplicação de métodos, técnicas, dispositivos e conhecimentos científicos.
} 


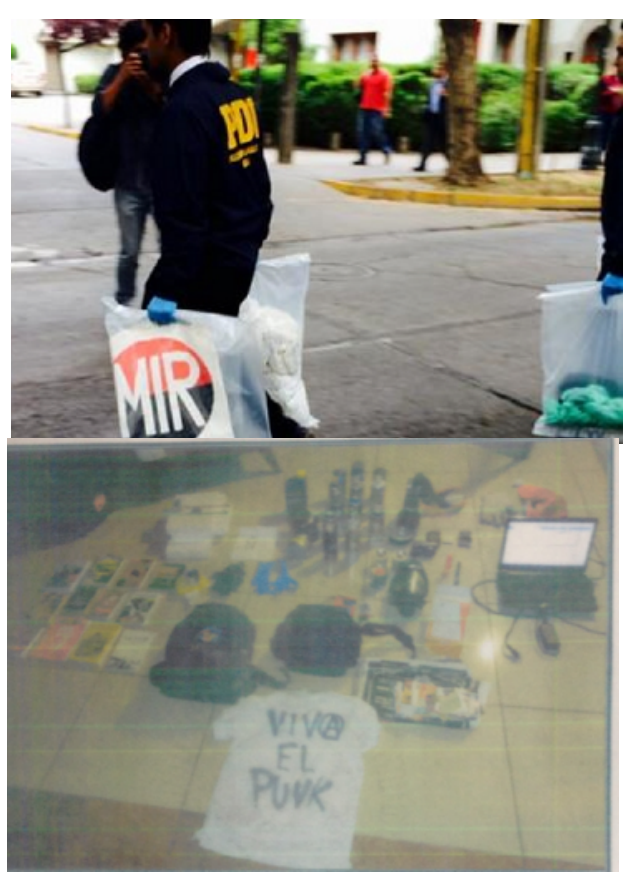

Figura 24 e 25: Evidências criminais (arquivo pessoal)

No relato oficial da investigação, o achado permitiu reconstruir a rede de suspeitos: a pretendida "célula anarquista". Na segunda fase da investigação, os policiais deixaram de lado as sofisticadas tecnologias e voltaram a ocupar, talvez, uma das formas mais antiga de vigilância das dissidências: perseguição à paisana de suspeitos. O estudante universitário que deu "match" foi seguido na rua, nos trajetos diários para o trabalho e para a casa, junto com amigos e também sozinho. "Se informa que no o7.DEZ. 2014, por volta das 1oh, agentes da Fuerza de Tarea de Delitos Complejos instalaram um ponto de observação e vigilância” - constatava um dos informes policiais enviados ao Ministério Público acerca da perseguição no seu lugar de trabalho. As fotografias são quase um close-up no rosto do jovem: "as perseguições devem ser a curta distância, menos de dois metros para manter a observação direta do alvo" - quase pedagogicamente explicava um dos policiais no estrado acerca das dinâmicas de perseguição. Poderíamos dizer, retomando Chamayou (2012), de uma caçada policial: há uma vinculação quase animal entre o corpo-policial e o corpo-perseguido, uma excitação em vigiar sem ser percebido.

O jovem foi fotografado falando por telefone, sorrindo, fumando e até beijando uma moça na rua, que, rapidamente, passou a ser a segunda suspeita 
do caso. Os laços de amizade e afetivos passaram a ser fonte de suspeita: deviam ser muito próximos daqueles que cometeram o ilícito, era a hipótese da acusação. Os policiais coletaram frases publicadas nas redes sociais onde os jovens expressavam sentimentos de afeto: "punky fofo, te amo" - frases que foram lidas pelos policias no estrado em tom neutro. Era a intimidade transmutada em evidência. Nesse fluxo, a família de Rosa passou a ser o alvo seguinte da vigilância secreta. No estrado, foram projetadas fotografias onde apareciam seus pais e irmãos, apresentados e comentados pelos próprios agentes policiais que realizaram as perseguições e vigilâncias: os espiões, agora, estavam ali materializados na nossa frente.

$\mathrm{Na}$ audiência, enquanto mostravam fotografias de seu pai conversando fora de sua casa, sua mãe, que estava sentada ao meu lado, olhava horrorizada e escondia a sua cara entre as mãos, em um misto de vergonha e raiva. Esse misto era um sentimento generalizado entre nós, amigos e parentes, que expressava uma perturbação: como a vida de alguém podia ser vigiada daquela forma e exibida sem nenhuma consideração. Sensação entre vulnerabilidade e promiscuidade causada por essa proximidade não consentida nem desejada. Todos os parentes diretos foram alvo de perseguição e de escutas telefônicas. Todavia, souberam disso apenas quando tiveram acessos ao dossiê da investigação. Conversas entre filhos e mães foram exibidas, conversas que discorriam de assuntos cotidianos, como horário de regresso à casa. No entender dos acusadores, a extensão das perseguições para os entes queridos devia-se ao simples fato de que não se podia desestimar a participação de parentes no ataque. $\mathrm{O}$ tom dos policiais, ás vezes, era de soberba, sem nenhum olhar aos jovens, nem os parentes. Nesse caso, trabalharam integrantes da Fuerza de Tarea de Delitos Complejos da Policía de Investigaciones, grupo multidisciplinar criado em 2014 para investigar crimes "mais complexos do que o comum", como a colocação de artefatos explosivos e incendiários. Policiais dessa unidade realizaram as "perseguições lícitas" - como insistiram em chamar a prática, jargão que foi ratificado pelo Ministério Público.

Paralelamente às atividades "operativas", outros policiais dedicaram-se ao trabalho em redes sociais: infiltraram-se no mundo virtual. Para tanto, criaram uma conta falsa de Facebook que era administrada por dois agentes que se apresentavam como "Carla". Com esse usuário, solicitavam amizade a 
amigos dos suspeitos. Ou seja, enganações com o aval do Estado. A fotografia de perfil da inexistente mulher, criada para perseguir anarquistas, não podia ser uma outra que um A rodeada por um círculo. Assim foi que examinaram curtidas, fotografias, comentários e contatos dos suspeitos e das pessoas com quem interagiam. Na audiência, vimos uma centena de imagens tiradas das redes sociais: os jovens acusados em festas, na universidade, em protestos, em suas casas.

Na hora de encarar as críticas da defesa sobre a falsificação de uma conta de Facebook, o policial reagiu da seguinte maneira: "mas ninguém é obrigado a aceitar uma solicitação de amizade". Além disso, agregou: "no Facebook, nada é realmente privado”. As atividades entre as contas vigiadas (comentários, curtidas), levaram aos policiais infiltrados a falar de um "círculo próximo”, embaçada em relações de amizade e confiança mútua. Em um diagrama um tanto infantil, colocaram-se os nomes dos suspeitos e de seus avatares de Facebook, com corações e outros símbolos, pretendendo-se plasmar visualmente a célula criminal. Ao mesmo tempo, começaram a ouvir conversações telefônicas e chats. Tudo sob a autorização do Ministério Público. Os conteúdos coletados online, fotografias, curtidas, sites compartilhados, comentários, identificação de "símbolos ácratas", defendia o Promotor, não só comprovavam as relações entre eles, bem como a "aderência ao anarquismo, sua desconformidade com o sistema e com a ordem em vigor". Foi assim que, de dois suspeitos, passaram a incluir um terceiro, amigo do primeiro, que foi vigiado e fotografado ao longo da investigação. A sua exnamorada, Adriana, também aluna da universidade, foi incluída na rede. Por último, um outro jovem, amigo de um deles.

Estabelecidos os cinco suspeitos, deu-se início a uma terceira fase de investigação. Cada um deles foi seguido na via pública, esperando que jogassem algum objeto no lixo. O objetivo? Recolher material orgânico "desprendido voluntariamente" para que servisse como prova de DNA a ser comparada com amostras obtidas de objetos coletados na universidade no dia do ataque. Policiais à paisana seguiram os jovens nos seus trajetos diários e colheram potes de iogurte, bitucas de cigarro e até mesmo resquícios de um cuspe no chão. Era necessário que fossem rejeitos dos quais fosse possível achar indícios de saliva. Era a primeira vez que se tentava essa estratégia, e obviamente não foi necessário consentimento algum para coletar o material 
genético jogado na rua. O material do lixo passa a ser informação pública. Os jovens foram seguidos nos seus bairros, universidade, sempre a curta distância, pois os objetos deviam ser colhidos de forma rápida, com luvas e sacolas especiais.

Naquele momento, todos nós tivemos que apreender sobre alelos, efeitos estocásticos e eletrofenogramas - termos desconhecidos por muitos de nós. Grande parte do julgamento teve relação com as pericias bioquímicas: os informes diziam que se confirmava a presença dos sujeitos no local do dia do ataque. Seus rastros estavam nas roupas. O que não informavam, no entanto - e esse foi o argumento dos defensores -, era que as amostras genéticas colhidas da universidade eram amostras misturadas: tinham informação de mais de uma pessoa. Algumas delas, de até quatro. E, nesses casos, o nível de exatidão dos exames é muito inferior, sendo desestimada em alguns sistemas de justiça o uso de informes bioquímicos embasados nesse tipo de amostra poluída.

\section{De mitocôndrias e mascarados}

Quando inventado o sistema de identificação de digitais no final do século XIX, Francis Galton, o mesmo que criou os "retratos compostos", ofereceria à polícia uma chave poderosa: a capacidade de identificar um culpável sem necessidade de ouvir a sua confissão (Rabinow, 1993). Liberavase a investigação policial de fazer o suspeito falar: só bastaria comparar dois datilogramas e a coincidência entre ambos, e isso revelaria que o sujeito esteve presente na cena do crime, mesmo que o negasse. Fato inegável de culpabilidade, pois a cada pessoa corresponderia uma digital única e irrepetível. Hoje, no século XXI, em audiências sobre litígios de paternidade e crimes sexuais, a análise do material genético extraído de sangue, saliva ou cabelo tem se convertido em umas das técnicas de bioidentificação mais populares. A cada indivíduo corresponderia uma combinatória de marcadores genéticos única. Celebrada como uma forma mais científica e objetiva, a identidade mais profunda é o DNA mitocondrial.

A história dos seguimentos da polícia à paisana e as provas de DNA ecoaram na imprensa nacional. Evidências "tipo CSI", informava um dos jornais de maior circulação no Chile (Las Últimas Noticias, o1 de julho de 
2015). Em 2011, a série televisiva Crime Scene Investigation (CSI) foi a mais assistida no mundo: o show, há mais de 15 anos, exalta o poder que teriam as tecnologias biométricas em processos investigativos. Nos Estados Unido, o sucesso do programa chegou a tal ponto que procuradores, defensores e juízes comunicaram sua preocupação com a influência que essas narrativas ficcionais teriam nas decisões dos integrantes do júri. Em tempos de incertezas globais, o programa transformou a ciência forense em fetiche que trouxe de volta a fé na eficácia do policiamento para se alcançar a "verdade" (Comaroff e Comaroff, 2016)235.

No Chile, o "efeito CSI" ressoa nas imagens institucionais utilizadas pela Polícia de Investigações do Chile em sua mais recente campanha de recrutamento. O aceno para esse programa de televisão é inegável, uma síntese estética acerca do que consistiria o trabalho policial para atrair mais jovens entre seus adeptos, imaginário que é aprofundado em vídeos corporativos que são exibidos em palestras de orientação vocacional nas escolas.

O atual símbolo da Polícia de Investigações do Chile inclui a imagem de uma dupla hélice de DNA, assinalando para o avanço tecnológico da instituição. Os peritos seriam os novos heróis: no cartaz da PDI, aparece uma mulher vestida com um macacão branco de tyvek -outra palavra que aprendi no julgamento de Adriana. As pessoas que jogaram coquetéis Molotov contra a delegação da polícia iam fantasiados com essas prendas ${ }^{236}$. Mimeses e apropriação: desde esse ataque, nas ruas, disseminaram-se encapuchados que hoje preferem seguir essa moda.

Voltando ao julgamento, a natureza científica da investigação policial foi enfatizada em várias oportunidades pelo Promotor: este caso foi

235 Os antropólogos Jean e John Comaroff têm discorrido amplamente acerca da popularidade das séries de policiais e detetives na cultura televisiva contemporânea, examinando como essas tendências se vinculam a mudanças globais em relação ao Estado e ao neoliberalismo. Mais detidamente, esses temas são discutidos por eles em entrevista que recentemente realizei para a Revista Plural da Universidade de São Paulo, disponível em: https://bit.ly/2ZnaPUn. Acesso em 02/09/2019.

${ }_{236}$ Ainda mais: são essas vestimentas as que hoje os mascarados têm preferido usar para participar dos confrontos com a polícia no centro de Santiago, bem como em Macul com Grecia, a esquina que analisamos no Capítulo 2. 
construído com base em "evidências científicas de alto valor probatório", mais designadamente a análise de materiais genéticos, evidências muito superiores aos depoimentos de testemunhas. Esta foi a primeira vez em que se utilizaram evidências de DNA em uma caso de "violência antissistêmica". O objetivo foi evitar um novo escândalo, como o Caso Bombas, quando, depois de 9 meses de prisão provisória e 6 meses de audiências, todos os imputados foram inocentados e absolvidos - isto, em parte, pelas provas irrisórias coletadas pela polícia: desde pôster de música a uvas-passas jogadas ao chão. Dessa vez, a investigação deveria apresentar dados irrefutáveis: rastros biológicos achados nas roupas usadas pelos atacantes da polícia, que deveriam por sua vez coincidir com as amostras tiradas dos suspeitos. A culpabilidade não dependeria da confissão, nem de testemunhas. Para incriminá-los, mostraram-se eletrofenogramas e as parafernálias políticas já descritas.

Adriana e os outros jovens imputados se negaram a entregar amostras de material genético, sangue, cabelo ou saliva, às policias. Nos quase dois anos de prisão preventiva, eles foram levados várias vezes ao laboratório, mas não cederam. No Caso Bombas, foram arrancados sem consentimento fios de cabelo dos suspeitos para as análises; e justamente por essa razão foram desestimadas como provas legítimas. Para o Ministério Público, o fato de que os imputados tenham se negado a colaborar só aumentava a suspeita de que eles eram os responsáveis de fato: algo deviam esconder. Porém, Adriana e o restante dos jovens se recusaram a colaborar porque, para eles, qualquer tipo de colaboração estava fora de cogitação: isso ia contra o princípio da "prisão combativa" cunhado nos anos 1990 e que, como presos políticos, no presente buscavam honrar. Mas não só no Chile. Em um fanzine que ganhei em uma feria anarquista em Barcelona se comentava acerca dos presos políticos na Grécia, explicando o porquê deles se negarem a entregar um rastro de seu corpo à polícia: não se pode "dar algo deles", a essa justiça que os incriminava. As bases de dados de perfis genéticos são uma frente de controle e supervisão das vidas, e por isso é preciso combater, mesmo que a estratégia para esse combate seja a recusa a entregar cabelo, cuspe e qualquer gota de sangue. 


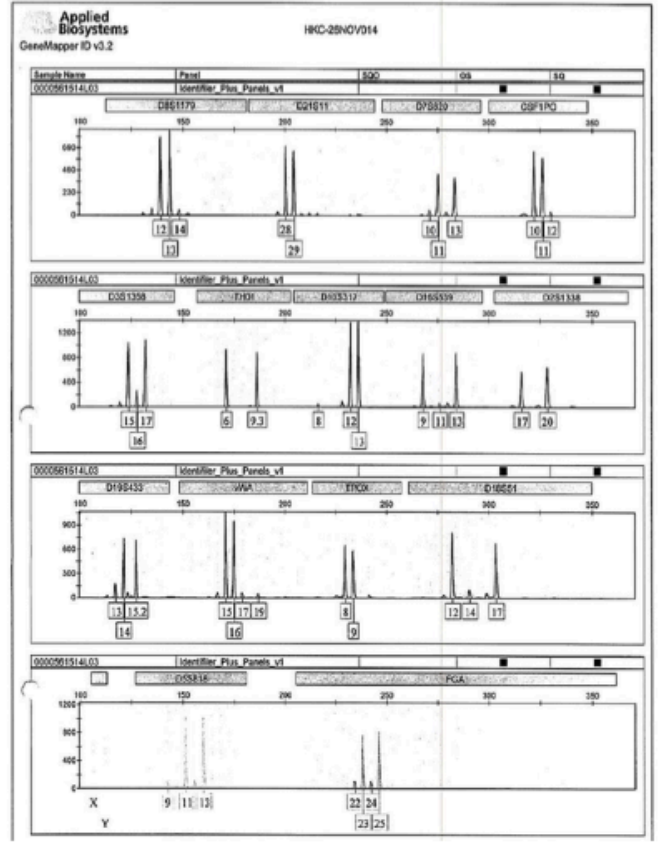

Figura 26:

Electrofenograma (arquivo pessoal, 2017)

"Estas pessoas perpetraram o atentado não só porque está no seu DNA, nas evidências, senão porque, além disso, eles tinham um motivo: as ideologias que professam e o ódio que tinham da polícia”. Com essas palavras, o Promotor encerrou a sua argumentação na última sessão do julgamento onde dirimia-se a pretendida culpabilidade de Adriana, Rosa e os outros três jovens acusados. Ou seja, essa sua fala sintetizava todo o processo persecutório: as novas tecnologias se vão somando às fantasias da ordem e da neutralização das dissidências, em que o self é desagregado (Nuttall e Mbembe, 2015), desde a mitocôndria, mas sem deixar de perseguir as ideologias. 


\section{PROLOGO}

\section{DE KEVIN E OS MACACÕES BRANCOS}

Nitrato, enxofre e carvão: estes eram os componentes presentes nas bombas que, supostamente, Kevin, um jovem de 21 anos de um bairro periférico de Santiago, fabricou e colocou em uma torre elétrica e em uma delegacia da polícia, em 2015. Embora nenhum dos artefatos tenha explodido, ele recebeu uma condenação de dezessete anos de prisão. A esses anos, já se somavam outros dois que já havia passado em prisão preventiva aguardando o início do julgamento. A diferença de outros casos que revisamos nesta tese, ele não foi condenado pela Lei Antiterrorista, mas sim pela Lei de Controle de Armas. Recentes modificações legislativas conseguiram aumentar exponencialmente as penas para o porte de armas explosivas, mesmo que elas sejam de baixa intensidade. Isto, claro, enquanto não se alcançam avanços nas modificações que há anos se pretendem realizar na Lei Antiterrorista que, no geral, buscam dar maior capacidade de infiltração às polícias.

Dezessete anos. A relação entre fatos punidos e anos de condenação estabelecidos pelo magistrado chama a atenção. Neste ano, por exemplo, um homem que matou uma jovem mulher e, logo depois, incendiou o apartamento onde cometeu o feminicídio recebeu exatamente a mesma condenação que Kevin. Qual o bem jurídico protegido no caso contra este jovem que nasceu em 1997? Ora, como vimos nesta tese, a paz pública.

Assim como nos outros julgamentos analisados, para condenar Kevin falou-se de motivações ideológicas, mas de forma um tanto quanto diferente. Os policiais e promotores, dessa vez, preferiram não falar de "anarquismo insurrecional". O termo estreado nesse julgamento foi: "ideologia refratária à autoridade". Nome, no mínimo, curioso. "O Refratário" é um dos principais 
sites de difusão do anarquismo insurrecional no Chile237. Na página, aliás, foram divulgadas as cartas que o próprio Kevin escreveu durante os dois anos vividos em prisão provisória.

Essa terminologia da polícia e do Ministério Público é uma nova tática de persecução criminal, aliás, uma que deu muito certo. Conseguir dezessete anos por duas bombas que nem chegaram a explodir, e que, portanto, não deixaram vítimas, nem danos materiais, parece uma verdadeira façanha.

No julgamento, revelou-se que Kevin já estava sob o olhar dos policiais. Agentes à paisana seguiam-no, tal como fizeram com Adriana e outros jovens. O fato de ele ter visitado na cadeia um outro jovem preso por "violência antissistema" o transformou, ipso facto, em suspeito imediatamente. Quando a polícia invadiu a sua casa, mais que o quarto, foi o telefone celular o que interessou aos peritos: buscavam-se imagens e documentos que evidenciaram que o suspeito pretendia lutar contra a autoridade:

Evidência EE36 vinculada ao número telefônico 77869804 que corresponde ao celular da marca Huawei. Há material alusivo à repressão. Outra imagem: um panfleto: "memória em revolta”. A capa do livro: "Os anarquistas de Bialistok". Uma parede grafitada: "ódio à polícia". A capa do livro: "A prisão como território de ação anticarcerária” (Condenação “Caso Kevin Garrido” Sexto Tribunal Oral en lo Penal de Santiago, 2018, p. 181).

Presos, livros anarquistas e mensagens de ódio a polícia. O jovem foi condenado pelos seus atos frustrados ou pelos seus "pensamentos refratários”? Um mês depois, Kevin, que havia passado seus dezenove, vinte e vinte e um anos em prisão, morreu esfaqueado por um outro jovem preso. Foi a primeira vez que um "preso anticapitalista" morria desse modo em um recinto penitenciário no Chile.

Quase como uma premonição, o comunicado anônimo que reivindicou uma das explosões pelas quais Kelvin havia sido culpado, discorria sobre a morte e a prisão: "Se a morte tem sua própria cor, deve ser a cor com a qual pintam as paredes das prisões. Porque o reino da morte lenta se acha no

237 Conforme se indica na plataforma online, "refratário talvez é o adjetivo qualificativo por excelência que os carcereiros e outras instituições de controle dão aos indivíduos que se recusam a obedecer às normas, aqueles que protagonizam fugas e motins". 
interior delas e podem se sentir a cada dia”. A empreitada contra a delegacia da polícia, explicava-se no texto, era ato de solidariedade com os presos políticos de todo o mundo. O documento foi assinado com a rubrica "Célula deflagrante Gerasimos Tsakalos”. Tsakalos foi preso, em 2010, na Grécia, por um ataque à bomba. Assumiu-se publicamente como integrante da Conspiração das Células do Fogo e de ter participado na colocação de explosivos contra as autoridades gregas. Passou oito anos em prisão e, hoje, em junho de 2019, passou para o regime aberto. Ele está vivo, Kevin morto.

Ao receber a facada em seu corpo (um tanto quanto magro, um tanto quanto infantil), Kevin adquiriu uma nova vida: somou-se à lista dos anarquistas falecidos nas últimas décadas ou na rua, por ação da polícia. Como Claudia López, em 1998, como Mauricio Morales, em 2009, transformou-se em ícone de memória.

A caminho da faculdade onde estou, atualmente, ministrando aulas de antropologia em Santiago, há poucos dias, vi um pequeno cartaz colado em um poste. Reconheci rapidamente a fotografia de Kevin: a imagem foi tirada no dia em que ele havia sido preso pela polícia. Nela, ele aparece muito sério, descabelado, com camiseta e olhando de frente. Um corpo em levante. No pequeno cartaz, aparecem junto a ele Mauricio e outros militantes mortos durante a democracia, uma genealogia de ausentes presentes.

O funeral de Kevin foi assunto de segurança pública: as autoridades dispuseram as tropas de elite da polícia de choque e todas as suas tecnologias: caminhões com jatos d'água, gases lacrimogêneos e até um helicóptero. Tudo para monitorar os parentes e amigos que acompanhavam o cadáver do jovem desde a sua casa até o campo-santo. Quem eram os suspeitos, os mortos ou aqueles unidos a ele por laços de amizade, parentesco, amor? Funeral suspeito e subversivo entre fumaças lacrimogêneas. No caminho para o cemitério, a polícia começou a barrar o passo de carros que levavam bandeiras vermelhas na estrada principal. Os policiais chegaram antes de todos: estavam aguardando. Pediram documentos de identidade e alguns já foram presos. $\mathrm{Na}$ confusão, porque a situação escalou rapidamente, um jovem foi atropelado pela polícia, ferido gravemente. Mas, lógico, a instituição policial negou a sua 
responsabilidade na ocorrência238. Há imagens, entretanto, que não podem ser negadas: com celulares, os assistentes gravaram policiais golpeando com cassetetes jovens que participavam do funeral, enquanto que mulheres gritavam: "pacos culiaos". O funeral foi descrito pela imprensa como "de alto risco".

Décadas atrás, cenas análogas aconteceram nos funerais de Mauricio Morales e Claudia López: repressão policial e enlutados em luta. Os relatos no caso de Claudia, que falam de policiais infiltrados no próprio campo-santo, entre os parentes e amigos, dizem:

Supimos de inmediato que las cosas se pondrían densas cuando al entrar por una gran recta que conducía al cementerio se veía una nutrida presencia policial que incluía un bus lleno de pacos sólo para nosotros... había gente extraña en el cementerio que claramente eran policías de civil: jóvenes con gorros y pañuelos en la cabeza recostados en el pasto del cementerio mirando hacia el horizonte como si se tratara de un inexistente picnic 239 .

Neste ano de 2019, imagens de jovens mascarados têm aparecido uma e outra vez nos meios de comunicação. Contudo, agora, não estão cobertos com camisetas nem lençóis, e sim com máscaras coloridas andinas e com macacões de tyvek, tal como os usados por aqueles que perpetraram o ataque à delegacia de polícia no caso de Adriana. A nova tendência de mascaramento ecoou nos jornais com manchetes curiosas: "O DNA do fenômeno dos macacões branco", “Quem está por detrás dos macacões brancos?”. Como já discuti aqui, a escolha da prenda usada para ocultar faces resulta desconcertante quando se observa que é exatamente a mesma que usam os peritos das polícias para coletar evidências nas cenas do crime. Embaixo, é possível observar duas figuras na mesma disposição corporal, ajoelhados, mas um com um coquetel Molotov na mão e ou outro, pegando uma evidência. Ao meu ver, trata-se de relações especulares, um gesto paródico dos encapuchados mais novos que estimaram que a melhor roupa para ocultar suas identidades seria aquela que usam os policiais para captura-los. Essas roupas brancas, hoje, se multiplicam nas ruas e nas fotografias de evidências e

\footnotetext{
${ }^{238}$ Acerca da repressão policial no funeral, matéria no jornal La Tercera, edição 05/11/2018. Disponível em: https://bit.ly/2lAOMgv-. Acessado em 02/05/2019.

239 Relato disponível em: https://bit.ly/2lWhBO5. Acessado em 23/04/2019.
} 
salas de audiências. Também, já há reportes de policiais à paisana usando os "macacões brancos" 240 .

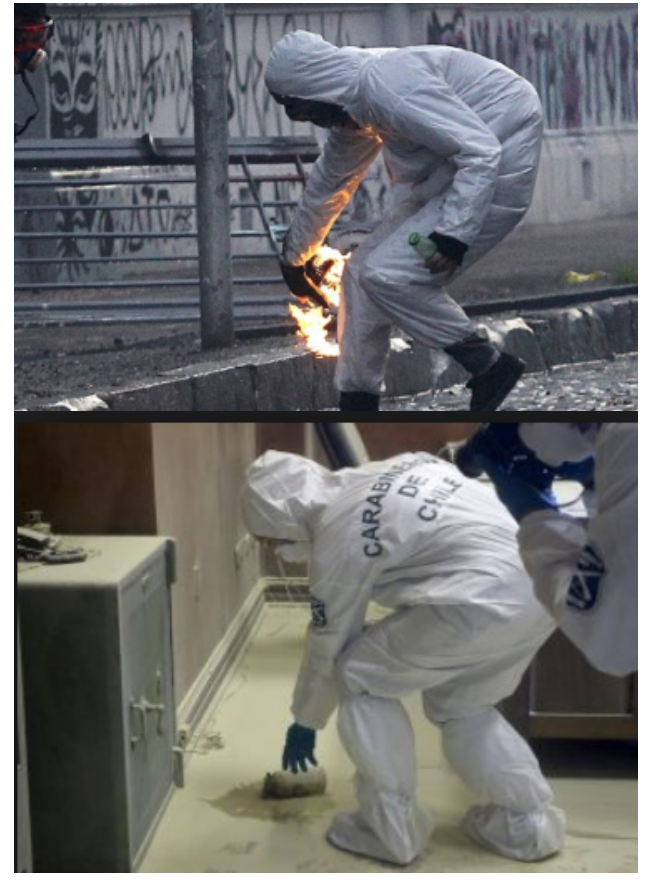

Figura 27 e 28:

Macacões branco (Rádio Bio-Bio)

A multiplicação dos macacões brancos tem relação direta com o aumento das ocupações de escolas secundárias. Alguns dos estabelecimentos educacionais públicos mais afamados de Santiago estão sendo ocupados por mascarados. Logo, passaram a ser analisados por policiais das unidades de inteligência. Seguindo este fato, e para encerrar esta tese, quero comentar brevemente as hipóteses fantasiosas sobre as quais a polícia têm trabalhado para revelar o que afinal há por detrás desses mascarados em roupas brancas.

Conforme declarações divulgadas pela imprensa, a polícia atribuiu a cada escola afetada por esses fenômenos uma linhagem histórica: em certa escola, há coletivos que se inspiram no MJL. Em outra, os jovens têm estabelecido conexões com o MIR. Ainda, há uma terceira, onde os estudantes simpatizariam com o FPRM. Tais vinculações, argumenta a polícia, são verificáveis pela presença de muros e paredes grafitadas com consignas dedicadas às antigas organizações de esquerda que atuaram na ditadura e nos

240 Comentários acerca da infiltração policial em: https://bit.ly/2krlcC3. Acessado em: 06/08/2019. 
primeiros anos da democracia. A escola onde estudaram os irmãos Vergara Toledo, hoje, tomada por mascarados de branco, é vista como uma continuidade dos jovens milicianos. Outros mortos também são vistos como causa da violência e dos levantes do presente: a escola que é associada pela polícia ao MJL é o lugar onde estudou o filho de quem foi o grande líder do movimento, já morto há vários anos. Ou seja, a suspeita do pai foi traspassada ao filho e a toda a comunidade escolar.

A essas tramas, fantasias policiais, entre o passado e presente, lógico, há que se somar o hálito do anarquismo, que recobre todas essas formas de dissenso radical. Como dizia um policial e psicólogo acerca dos recentes protestos e ocupações: "Siempre atacan en grupo ya que así se sienten parte de algo, además al perder el individualismo se pierde la conciencia de los actos y el peso de la culpa, atacan de manera anárquica, como una manada para validar sus actos" 241 . É assim que os mascarados mudam suas roupas ideológicas. Seja como for, me parece que a sua imagem fantasmagórica continuará a assombrar o Chile por várias décadas adiante.

241 Matéria jornal La Cuarta, edição o5/09/2018. Disponível em: https://bit.ly/2keQIEI. Acessado em: 08/09/2018. 


\section{ANEXOS}

\section{Notas de uma visita}

\section{Entrando na prisão}

Para visitar um detento na prisão chilena, assim como no Brasil, é preciso se inscrever previamente em um registro no rol de visitas, lista que as prisioneiras, no caso da prisão de San Miguel, podem modificar mês a mês, com um máximo de 10 inscritos. Uma vez incluído, é preciso realizar um cadastro em algum dos escritórios de Gendarmería de Chile, procedimento burocrático no qual basta apresentar a carteirinha de identidade e informar dados pessoais (data de nascimento, endereço, ocupação), bem como explicitar o vínculo com aquele que se pretende visitar: parente ou amigo. Ato contínuo, se é fotografado por uma pequena câmera, imagem que passa a compor a base de dados digital operada pela Gendarmería de Chile.

Em janeiro de 2016, quando realizei o cadastro no centro de Santiago, época do ano quando o ritmo da cidade fica mais calmo, não havia filas. Só havia uma mulher jovem com sua filha pequena na minha frente, perguntando sobre o procedimento para visitar um parente em um presídio no norte do país. A funcionária, nos seus 40 anos de idade, também estava com sua filha de uns 8 anos; provavelmente não tinha com quem deixá-la na época das férias escolares. Ao informar que precisava inscrever, a funcionária olhou pra mim e perguntou: “¿Tú vas a Punta Peuco, no?”. Quanto agradeci poder dizer que não!

Em 1995, no governo do ex-presidente, o democrata cristão Eduardo Frei, criou-se o Centro de Detención Preventiva y Cumplimiento Penitenciario Especial Punta Peuco, recinto destinado a receber agentes das forças armadas e civis que trabalharam para os aparelhos repressivos, condenados por crimes cometidos durante a ditadura de Pinochet, principalmente homicídios, sequestros, tormentos civis e associação ilícita. 
Desde a sua inauguração, discutiu-se, na opinião pública, o tratamento diferenciado dado aos militares, entre eles, ex-generais, majores e coronéis. $\mathrm{O}$ Instituto de Diretos Humanos (INDH), em 2015, confirmou as diferenças nas condições de reclusão: nos quartos individuais com banheiros privativos, os detidos possuíam TV plasma, frigobar, televisão a cabo, além de contar com áreas verdes em partes do presídio, inclusive churrasqueiras, entre outras instalações inexistentes no restante dos estabelecimentos penitenciários do país ${ }^{242}$. Para além do fato de eles serem militares, discutia-se como o tratamento diferenciado respondia à classe social dos condenados, mais alta que aquela que caracteriza a maior parte da população carcerária no Chile.

Voltando, então, ao comentário da funcionária, seria pouco conveniente entender aquela ironia do destino como uma simples anedota ir visitar uma suspeita de "terrorismo anarquista" e ser confundida com uma familiar de quem se dedicou a matar "terroristas" durante a ditadura de Pinochet. Para tornar inteligível aquele dialogo mínimo é preciso atentar para a diferenciação entre presídios, presos e suas visitas. É provável que no encontro face a face com a funcionária nesse espaço institucional circunscrito e concreto o meu corpo, o meu jeito de falar e de vestir, talvez até o fato de entrar com um livro na mão, foram interpretados pela mulher com base em marcadores sociais de diferença de classe, gênero e raça. Ser mulher, jovem e branca me colocou no plano de potenciais visitantes, familiares e amigos dos prisioneiros do Penal Punta Peuco, que são, tal como os detentos, pertencem a setores sociais médios e altos. Em outras palavras, aos olhos da funcionária, eu não lhe parecia uma visita típica de alguém preso em um recinto penal comum, mas sim daqueles que visitam aquele outro tipo de prisão "privilegiada".

\section{Acessos sempre incertos}

A primeira vez que fui visitar Adriana foi na última manhã de janeiro de 2016. Eram 1oh3o. Para meu espanto, não havia ninguém na rua do lado de

242 A visita do INDH ao recinto penitenciário Punta Peuco, em 30 de abril de 2015, respondeu ao pedido dos presos por considerarem que seus direitos humanos estavam sendo vulnerados. Conforme diretiva do organismo, as condições materiais do recinto eram superiores em termos de qualidade quando comparadas a qualquer unidade penal do Chile. Informe na íntegra disponivel em: shorturl.at/clwTX. Acessado em: 17/05/2016. 
fora. Aproximei-me, então, do único funcionário visível, que estava dentro de uma guarita: "Buenos dias. ¿Cómo hago para entrar? Es primera vez que vengo". O funcionário, perto de seus 50 anos, sorriu para mim e perguntou o nome da interna e o módulo. Eu tinha apenas o nome dela. "!Ah! Pero ella es la universitaria, ¿no es verdad? Ella está en el módulo de connotación pública. Ya vinieron varios profesores a verla”. De milhares de internas, o agente penitenciário conseguiu se lembrar da universitária. Do total de pessoas privadas de liberdade no Chile, só 1,8\% tem nível universitário incompleto e 0,5\%, universitário completo (Paz Ciudadana, 2015) ${ }^{243}$. Nesse sentido, a presa universitária que recebe visitas do mundo acadêmico era uma exceção a ser lembrada.

Ele me indicou o portão por onde eu deveria ingressar. A porta de metal, que lembra mais uma escola pública que uma prisão, estava fechada. Depois de gritar, apareceu um agente de segurança. Depois de descer algumas escadas, chega-se à guarita, onde, no geral, há de cinco a sete funcionários homens e mulheres jovens - vestidos de uniforme verde escuro e coturnos. Os homens de cabelos curtos, as mulheres de cabelo preso e maquiadas. Nesse horário, é comum que eles conversem descontraidamente e, não poucas vezes, escutem música. O momento de maior afluência é mais cedo, às 9 h, quando abrem as portas do recinto. Os familiares chegam pontuais com pacotes com alimentos que são cuidadosamente revisados, procedimento que, às vezes, demora até 40 minutos, tempo perdido da visita que dura até o meio dia.

$\mathrm{Na}$ guarita, é preciso dizer o nome e entregar o documento de identidade, que é analisado por um escâner. Na tela do computador operado pelo funcionário, aparecerá a fotografia e dados indicando que as informações necessárias foram entregues no momento do cadastro na Gendarmería de

243 A Gendarmería de Chile não disponibiliza dados sobre a classe socioeconômica dos internos, e as pesquisas empíricas que abordam esse fator são quase inexistentes. Contudo, podemos inferir que há uma precariedade socioeconômica dos homens e mulheres com base no nível educacional dos internos antes de terem sido privados de liberdade: 3,3\% sem escolaridade, 39,5\% tinha educação primária incompleta; $22,1 \%$, básica completa; $21,1 \%$, secundária incompleta; 7,8\% educação secundária completa; $1,4 \%$ educação técnica incompleta; $2,3 \%$ educação técnica completa; $1,8 \%$, universitária incompleta, e só o,5\%, universitária completa (Paz Ciudadana, 2015). 
Chile. O nome é conferido na lista da interna (documento em papel), pergunta-se o vínculo com a presa e analisam o visitante, comparando a imagem que aparece no sistema e aquela do documento de identidade. Em seguida, deve-se assinar ao lado do nome, escrito a mão pelo agente de segurança, em um caderno junto ao resto dos visitantes que ingressaram no dia. Então, em troca do documento, recebe-se uma ficha de plástico com um número: 136.

Depois de me entregar a ficha, revistaram a minha carteira. "No puede entrar con la BIP [bilhete único]". Tinham me avisado antes, mas eu não tinha acreditado: "como fazem as pessoas para chegar e voltar para casa?" perguntei. Sem resposta, me mandaram esconder ele "por ahi”" na rua. Sem saber o que fazer, um guarda muito jovem que estava na porta, ao ver meu desconforto, ofereceu-se para cuidar do bilhete por mim. "Pero no le diga a nadie, ¿ya?" - ele me diz, enquanto guardava o documento na sua jaqueta institucional. Seria esse tipo de exceção habitual? De fato, percebi, na atitude do jovem, uma certa condescendência. As questões que se colocam são diversas: isso ocorreu por ser a minha primeira vez na cadeia? Por ser mulher branca? Por ser de classe média? Jovem? Pelo ritmo mais descontraído do verão?

Regressando à vistoria, olharam as bolachas integrais, em sacolas transparentes tipo ziplok, que eu estava levando para Adriana. Admitido o ingresso do alimento, depois, meu corpo foi o novo alvo da inspeção. Ainda na guarita, olharam minha roupa cuidadosamente, que foi aprovada: calças cinzas, sapatos pretos, camiseta roxa, cabelo preso, sem maquiagem nem brincos ou outros acessórios. As normas de vestuário e apresentação pessoal são múltiplas, confusas e restritas. Tênis, chinelos tipo "havaianas", sapatos de salto, estão todos proibidos. Também roupas de cor preta, verde ou azul escuro. Assim como blusas sem mangas ou com decote, saias acima dos joelhos, leggins, bermudas, blusas com capuz, bonés, óculos escuros, roupas esportivas. Sutiãs com bojo, maquiagem, extensões de cabelo, unhas postiças, piercings, são igualmente proibidos. Entretanto, as normas variam de recinto para recinto: as “havaianas", que são proibidas na prisão de San Miguel (e pelo qual me impediram de entrar na terceira visita), são permitidas no Centro de Detención Preventiva Santiago Uno, onde estão presos ou outros jovens vinculados ao caso de Adriana. Por outro lado, já aconteceu em mais de uma 
ocasião de me dizerem que não podia ingressar com um item que já havia usado previamente, acrescentando que, pela última vez, me permitiriam ingressar com essas roupas. Assim sendo, cada vez que chego na guarita, há possibilidade de ser impedida de ver Adriana por algum detalhe qualquer, decisão que está nas mãos do funcionário do turno.

$\mathrm{Na}$ guarita, há um pequeno cartaz que indica alguns dos itens proibidos de serem usados pelos visitantes. Contudo, foi apenas em um site de um grupo de familiares de presos onde consegui ver uma lista mais detalhada. Analisando a lista de roupas e acessórios proibidos, parece difícil acreditar que há razões de segurança para vetar um ou outro artefato. De um lado, parece que o que está sendo excluído de entrar na prisão são os corpos femininos que exibam ou que marquem contornos do corpo para além de um limite que a administração penal considera apropriado (leggins, decotes, saias acima do joelho, etc.). De outro, vemos na lista roupas que são frequentemente utilizadas por jovens, sobretudo de bairros mais populares (roupas esportivas, tênis, bonés, bermudas). Essa arbitrariedade evidente nos coloca frente a uma pergunta: afinal, por que a apresentação pessoal de quem vai visitar alguém na prisão deve ser gerida por critérios da instituição penal? Por que os visitantes são forçados a perder o controle de sua própria imagem? Sobre essa questão, a mãe de Adriana me contou como ela mesma não conseguiu passar no primeiro dia pela vistoria, pois ninguém lhe havia explicado que roupas devia usar. Ela teve, portanto, que retornar a sua casa e se fantasiar, nas palavras delas, para ver a própria filha.

Dada a facilidade de errar, ou da norma mudar sob a discricionariedade dos funcionários, fora da cadeia - e isto me ensinou a mãe de Adriana -, entre os cartazes de serviços de advogados, há uma pequena mercearia que aluga roupas em caso de recusa na vistoria. Aí, paga-se $\$ 400$ ( $R \$ 1,50)$, sendo que bolsas e mochilas podem ser guardadas enquanto se realiza a visita. É necessário decorar o seu número: 13. Na terceira visita, quando fui recusada de entrar por usar chinelos, a senhora da mercearia me ofereceu alugar 
sapatos de tamanho maior que os meus244. Experimentei, mas não consegui andar direito. Resolvi ficar fora da cadeia esperando a mãe de Adriana, sentada embaixo de uma árvore, enquanto os funcionários da porta, que me excluíram pela "informalidade" dos chinelos, ouviam muito alto uma música regetón.

\section{Cavidade suspeita}

Quando se consegue ser aprovada na vestimenta, a revista tem por alvo o corpo, a própria pele. É preciso passar por um corredor escuro, um pequeno labirinto que confunde mesmo que não seja a primeira vez que se passa através dele. Depois, deve-se esperar que a guarda de segurança chame para que se possa passar por um portal de detector de metais e, seguidamente, entrar em uma sala pequena que tem um espelho e se sentar na cadeira denominada B.O.S.S. (Body Orifice Security Scanner)245. Quando se senta na cadeira, os sensores magnéticos, automaticamente, detectam objetos metálicos. Nesse ato de sentar-se, são revistadas a cavidade abdominal, a cavidade anal-vaginal e a área das pernas e dos pés. Conforme uma das empresas norte-americanas que vende essa tecnologia afirma, as vantagens do produto são a facilidade e a rapidez de uso (só é preciso se sentar por alguns segundos), além de ter maior precisão que o portal de detector de metais simples e não ser intrusivo ou invasivo. Das várias vezes que já me sentei na cadeira, o apito foi acionado por moedas que havia esquecido nas calças ou por elementos metálicos de meus sapatos.

Depois de passar pelos detectores de metais, a funcionária me chamou para entrar em um cubículo de cor cinza e com piso frio. Olhei para ela sem

\footnotetext{
244 Depois, fiquei sabendo que foi a mãe de Adriana que deu a ideia de alugar roupas à dona da mercearia e que entregou a ela uma sacola de prendas que se ajustavam aos requerimentos da Gendamería de Chile. Contudo, em uma visita posterior, ao ir procurar as nossas bolsas, a senhora da mercearia devolveu as roupas à mãe de Adriana dizendo que as pessoas não gostavam dos itens: ou seja, do mesmo modo que eu, preferiam não entrar para visitar seus entes queridos do que entrar com roupas que as faziam sentir-se incômodas.

245 Note-se que a palavra boss em inglês significa chefe. Os publicitários queriam jogar com uma ironia fina ao nomear um dispositivo desse tipo daquela forma? Tal foi a pergunta que me fez a antropóloga Bruna Triana.
} 
saber o que fazer, mas sabia (e temia) o que iria suceder246. Conforme as instruções, tive que abaixar as calças, levantar a camiseta e o sutiã na frente da jovem funcionária, que parecia tão constrangida quanto eu. Em um tom de cumplicidade, me perguntou: “¿Es la primera vez que vienes, no?”. A agente penitenciária, então, olhou rapidamente as partes nuas de meu corpo. "Ya. Puedes bajarte la polera”. Em seguida, mandou tirar os sapatos e as meias. Além disso, tive que mexer meus cabelos e ela revisou os bolsos da minha calça com as suas mãos. Já aprovada, olhou para mim com certo exaspero, apontando para o meu pulso: "No puedes entrar con reloj. Te voy a dejar pasar pero que no lo vean los otros, ¿ya?”. Aos visitantes não é permitido ter controle do tempo no momento em que entram na prisão. Não há relógios na sala de visitas; a forma de saber quanto tempo se passou é por meio de apitos controlados pelos agentes penitenciários que avisam quando se passou as duas primeiras horas e, depois, quando finaliza a visita.

Nesse momento, suspeitei mais uma vez que aquele tratamento "compreensivo" da agente de segurança não era algo comum com todas as mulheres que visitam o recinto prisional, especialmente no caso das mais pobres. Além disso, como soube logo depois, alguns amigos de Adriana foram intimidados por suas vestimentas e cabelos: orelhas com furos de piercings, cabeças raspadas e tatuagens. Também foram intimidados verbalmente pelo tipo de crime pelo qual Adriana foi acusada. No meu caso, talvez por ser mais velha que eles, já nos meus trinta e tantos, nunca me foi dito qualquer comentário do tipo. Por outro lado, amigos de Adriana me disseram que a guarda das segundas-feiras, dia quando não consegui passar por causa dos chinelos, era, de fato, a mais "barra pesada", sobretudo se comparada com a das sextas-feiras, a mesma que me permitiu entrar com o relógio.

Com respeito à revista vexatória, desde 2002, foi proibido aos funcionários da Gendarmería de Chile introduzir dedos no anus ou na vagina das visitantes, assim como pedir para que elas se desnudassem completamente - isto só depois que uma mulher de 60 anos denunciou o

\footnotetext{
${ }^{246}$ Quando conheci pela primeira vez o CPF San Miguel como pesquisadora da Gendarmería de Chile, a revista íntima foi uma parte que não experimentei. $\mathrm{O}$ mesmo acontece com outros profissionais que ingressam nas prisões, como os advogados, médicos e psicólogos, bem como com os voluntários das pastorais.
} 
procedimento à Corte de Apelaciones de Santiago, invocando a Convenção Americana de Direitos Humanos, argumentando contra o tratamento vexatório sofrido no Centro de Cumplimiento Penitenciario de Colina II ao visitar o seu filho. A Corte declarou inconstitucional tal procedimento, por danificar a integridade física, psíquica e a dignidade dos visitantes. Todavia, o procedimento persiste e seu sentido parece ser a de castigar e constranger a quem tem vínculos de amizade ou de parentesco com quem está sob a suspeita de crime.

Quando voltei a visitar Adriana na primavera de 2016, a experiência da revista vexatória deixou de ser tão compreensiva. Dessa vez, com as calcinhas abaixadas, fui forçada a me agachar. Como no verão isso não tinha sido exigido, protestei: “¿eso es parte del protocolo?” A jovem funcionária respondeu: "Si, pregúntele a quien quiera. Por mí no hay problema pero hay mujeres que se entuban celulares" - respondeu-me enquanto que, com as mãos, apontava seu púbis. Seguidamente, ela própria se agachou para me mostrar o que eu tinha que fazer. Acrescentou, então: "Las señoras aquí llegan solitas, se bajan los calzones y se agachan”. Tentei reclamar mais uma vez, mas se queria ingressar não tinha outra opção247.

Nas visitas posteriores, às vezes, não me foi exigido agachar. Ou seja, o protocolo nem sempre é seguido. Sempre esperei para ver se as agentes penitenciárias davam essa ordem ou não; em outras palavras, recusei-me a automatizar tal procedimento. A indisposição sentida nesse momento de intimidade imposta com uma estranha em uniforme que tem por tarefa inspecionar o corpo alheio é uma experiência difícil de transmitir ao leitor. É uma mistura de vulnerabilidade, humilhação e raiva. Sentimentos que ainda se acrescentam a um certo asco, uma vez que a agente de segurança encarregada das revistas estava fumando. Mesmo que seu tratamento tenha sido mais "atencioso" - não pediu para que eu agachasse e me mandou botar

247 Conforme a administração penal informou ao Instituto Nacional de Direitos Humanos (INDH), não era pedido às visitar de se agacharem: "Según se comunica, el registro corporal de personas adultas implica un auto desprendimiento de ropa para la revisión de las prendas, pero no aplica la realización de sentadillas" (INDH, 2017, p. 17). Contudo, as presas informaram à visitante desse instituto que, de fato, às vezes, os parentes e amigos eram forçados a realizar tais procedimento para poder seguir com as visitas. 
as meias rapidamente porque o chão estava muito frio -, a proximidade do cigarro com o meu corpo, simplesmente, me arrepiou ${ }^{248}$.

Sem ter evidências de sua eficácia, a continuidade da revista vexatória, tanto no Chile como no Brasil, parece mais bem uma forma de extensão da punição dos reclusos e das reclusas a seus familiares e amigos. Com efeito, o controle e os procedimentos que recaem sobre as visitantes, na inspeção de seus corpos e de seu comportamento, terminam por equiparar temporariamente visitantes a reclusos (Cunha, 1994; Ricordeau, 2012). E, ainda mais: a revista vexatória pode ser pensada como "ritual de degradação" (Godói, 2015), até como uma forma de desincentivar o mantimento das redes familiares. Há mulheres que não suportam passar por essa situação, sendo que, muitas vezes, seus próprios familiares presos pedem para que elas não sigam com as visitas (Silvestre, 2011). No caso de Adriana, a maior parte das mulheres da nossa família não foi visitá-la por medo do procedimento. Com respeito à revista dos corpos masculinos, conforme me informou o seu pai, o processo é também constrangedor, mas menor por não ter um tipo específico de cavidade corporal, a vagina, inspecionada.

\section{Corpos marcados}

Todo visitante sai do recinto penitenciário com a mesma marca: um carimbo vermelho com um símbolo da Gendarmería estampado no antebraço. Todos: mulheres, homens, crianças e bebês que nesse dia de verão fomos visitar nossos parentes 249 . Junto a esse carimbo do Estado estampado na pele, todo visitante-familiar é marcado com um outro logotipo, invisível, estampado do lado do primeiro, que só se revela ao ser iluminado com uma lanterna ultravioleta utilizada pelos funcionários de segurança no momento de se ingressar e sair do lugar onde as acusadas recebem os visitantes. São tecnologias de inscrição, marcas que são carregadas a partir daquele momento e que se estendem para além da prisão, no percurso de retorno à casa ou ao trabalho.

248 Sobre essa mistura de sensações, Biondi (2010) relata com muita sensibilidade e intensidade essa passagem obrigatória pela revista vexatória.

249 No Brasil, familiares são marcados também no braço esquerdo com carimbo contendo o número do raio (Biondi, 2010). 
Ser carimbado é o que se segue à inspeção corporal. Deixa-se o cubículo da revista, passa-se a buscar as sacolas já revistadas, avança-se até a primeira gaiola, quando é preciso mostrar a ficha entregue na guarita. Antes de entrar no corredor que leva a quadra de ginástica onde as presas esperam amigos e parentes, o antebraço dos visitantes é marcado por um funcionário homem. Conforme a minha experiência, às vezes, os agentes penitenciários fazem gestos muito delicados para estampar a marca, gesto que resulta um tanto quanto exagerado quando se compara a toda violência do ritual de visita. Feito isso, destrancam a grade de metal com uma chave; avança-se por um corredor escuro dividido em dois por uma grade metálica: há um corredor para os homens e outro para as mulheres 250 . No final, há uma outra grade que marca a fronteira entre o corredor e a área de visitas - é possível ver rapidamente os entes queridos sentados em cadeiras espalhadas por toda a quadra. Antes da permissão para cruzar o espaço, os carimbos são novamente revisados por funcionários homens, que às vezes estão acompanhados de agentes mulheres.

\section{Limiar}

Godói (2015) retoma a ideia de território liminar proposta por Gwenola Ricordeau (2012) para pensar a sala de visitas. O cubículo da revista vexatória é território liminar entre o dentro e o fora da prisão, onde "a visitante ainda não está inteiramente dentro - porque ainda não acabou de entrar, ainda não viu quem quer ver - e já não se encontra do lado de fora porque já não está livre das exigências da administração penitenciária” (Godói, 2015, p. 189). Em outras palavras, a visitante se encontra em um espaço meio livre, meio preso, acrescenta o autor.

Recuperando os comentários de Gagnebin (2014) sobre o conceito de limiar na obra de Walter Benjamin, a respeito da arquitetura, vale acrescentar que o limiar é aquilo que deve possibilitar a transição de um lugar determinado a um outro distinto, às vezes oposto. Portão, vestíbulos, corredores, soleira de porta têm por função possibilitar tal transição. Tentar atravessar as múltiplas portas, grades e corredores da Prisão de San Miguel é

250 Uma vez terminada a visita, homens e mulheres visitantes se colocam na respectiva fila, sendo os homens liberados primeiro. 
transitar por um contínuo de passagens que compõem a experiência de visita de uma parente ou amiga presa. O limiar, contudo, não só se refere à ordem do espaço, mas também à ordem do tempo: um tempo intermediário e indeterminado, de extensão variável e indefinida. Assim, por exemplo, depois de atravessar a fronteira, o primeiro portão que separa a rua e a prisão, nas seguintes passagens, vai-se adentrando um lugar de transição que pode se tornar em qualquer instante zona de estancamento e exaustão, limiar inchado e caricato, como aqueles corredores, salas de espera e portas que as personagens de Franz Kafka transitam, às vezes sendo, simplesmente, capturados por uma espera indefinida, seja pelas decisões, seja pelas apatias de funcionários burocráticos. 


\section{Bibliografia}

ACEVEDO, N. 1998: El plebiscito para la Concertación, guerra para el MAPULautaro: lecciones de dos elecciones opuestas. Revista Pretérito Imperfecto. $\mathrm{N}^{\circ} 1$, 2012.

- Continuidades en el Chile post-dictatorial: el accionar del MAPU-Lautaro y la respuesta de la Policía de Investigaciones en el gobierno de Patricio Aylwin (1990). Revista DiveRgencia, vol. 719, 2013.

- Detención por sospecha o la prevención en contra los pobres y los movimientos sociales. Blog Redseca. 20 de julho, 2015.

AGGIO, A. \& CÁCERES, G. Chile: processo político e controvérsias intelectuais. Lua Nova, (49), p. 87-111, 2000.

AGÜERO, C. ¿Conforman las sentencias penales un género discursivo? Estudios filológicos 53, p. 7-26, 2014.

AGUILERA, O. \& DUARTE, K. Aproximaciones interpretativas a las relaciones entre juventudes, violencias y culturas. Revista Observatorio de Juventud, Año 6 n.23 , 2009.

ALBORNOZ, M. Policías, cónsules y anarquistas: la dimensión transatlántica de la lucha contra el anarquismo en Buenos Aires (1889-1913). IBEROAMERICANA, 17(64), p. 57-79, 2017.

ALBORNOZ, M. \& GALEANO, D. Anarquistas y policías en el atlántico sudamericano: una red transnacional, 1890-1910. Boletín del Instituto de Historia Argentina y Americana “Dr. Emilio Ravignani”, (47), 2017.

ALVARADO, P. Criminalización política mediante el uso selectivo de la estrategia antiterrorista del Estado chileno (200O-2014). TCC, Universidad de Chile, 2015.

ANÔNIMO. Macul con Grecia: Fuego en las manos contra la autoridad, 2006. 
ANÔNIMO. Terror en la ciudad\#2. Cuentos Subversivos de Ayer, Hoy y Siempre, 2009.

APOIFIS, N. Fieldwork in a furnace: anarchist, anti-authoritarians and militant ethnography”. Qualitative Research, p. 1-17, 2016.

ARANCIBIA, E. Las Milicias de la Resistencia Popular. El MIR y la lucha social armada en Dictadura 1979-1984. Ediciones Escaparate, 2015.

ARETXAGA, B. Maddening states. Annual review of anthropology, 2003, vol. 32, no 1, p. 393-410, 2003.

- Playing terrorist: Ghastly plots and the ghostly state. Journal of Spanish Cultural Studies, vol.1, p. 43-58, 2000.

ARTHUR, P. How transitions reshaped human rights: A conceptual history of transitional justice. Hum. Rts. Q, 31, 2009.

AUGUSTO, A. Política e antipolítica: anarquia contemporânea, revolta e cultura libertária. Tese (Doutorado em Ciências Sociais), PUC-SP, 2013.

AUYERO. J. \& JOSEPH, L. Introduction: Politics under the Etnographic Microscope. IN: JOSEPH, L. et al. (Eds.) New perspectives in political ethnography. New York: Springer, 2007.

AYLWIN, P. La transición chilena: discursos escogidos, marzo 1990-1992. Editorial Andrés Bello, 1992.

BADILLA, M. The Day of the Young Combatant, generational struggles in the memory field of post-dictatorship Chile. Memory Studies, 2017.

BARGU, B. Starve and Immolate: The Politics of Human Weapons. Columbia University Press, 2014.

BARRÍA, G. El Chaca, la Chica y el Jonny: represión y muertes en el Chile democrático: Santiago, 1988-20o8. TCC (Licenciatura en Historia), Universidad de Chile, Santiago, 2012.

BECKER, H. Whose side are we on? Social Problems. Vol.14, N.3, 1967.

BELLEI, P. Ritos y Mitos Urbanos: análisis sociocultural de las expresiones de Violencia Callejera en las Fechas Emblemáticas. Tese (Mestrado em Sociologia), Universidade do Chile. 2017.

BENGOA, J. Reconciliación e impunidad: los derechos humanos en la transición democrática. SUR, Centro de Estudios Sociales y Educación. Proposiciones N. 25. 1994. 
BERENGUER, C. Recados de la prisión en las fisuras del poder. IN: OLEA, R. (Ed.) Escrituras de la diferencia sexual. Colección Contraseña Estudios de Género. Santiago: LOM - La Morada, 2000.

BIONDI, K. Junto e misturado: uma etnografia do PCC. São Paulo: Terceiro Nome, 2010.

BRINGEL, B. Sentidos e tendencias do levate brasileiro de 2013. IN: Bringel e Dominguez (org) As Jornadas de Junho em perpespectiva global. NETSAL-IESP/ UERJ. 2013.

BUBANDT, N. \& WILLERSLEV, R. The dark side of empathy: Mimesis, deception, and the magic of alterity. Comparative Studies in Society and History, 57.1, p. 5-34. 2015 .

BUBANDT, N. From the enemy's point of view: violence, empathy, and the ethnography of fakes. Cultural Anthropology, 24.3, p. 553-588, 2009.

CAICEDO, L. La situación particular de las mujeres recluídas por delitos de drogas. IN: COPORACIÓN HUMANAS CHILE. Políticas de drogas y encarcelamiento de mujeres en América Latina: la experiencia de México, Chile y Colombia, 2015.

CALDERON, G. Mateluna, 2017. Sem publicação oficial.

CANDIA, R. Operación Cavancha. Santiago: Ceibo, 2015.

CARDOSO DE OLIVEIRA, L. Pesquisa em versus Pesquisas com seres humanos. IN: VÍCTORA, OLIVEN, MACIEL; TORO (orgs.) Antropologia e ética: o debate atual no Brasil. ABA e Editora da Universidade Federal Fluminense, 2004.

CARLETON, D. \& STOHL, M. The role of human rights in US foreign assistance policy: A critique and reappraisal. American Journal of Political Science, 1002-1018, 1987.

CARRASCO, B. \& LÓPEZ, M. Agente encubierto: análisis crítico de su regulación en la legislación nacional. TCC (Ciências Jurídicas), Universidade do Chile, 2013.

CARREÑO, J. Compro fierro. Santiago: Balmaceda Arte Joven, 2007.

CAVALLO, A. Golpe 11 de septiembre de 1973.: Las 24 horas más dramáticas del siglo XX. UQBAR, 2013.

CAVARERO, A. Horrorism: Naming Contemporary Violence. Columbia University Press, 2009.

CHAMAYOU, G. La société ingouvernable. Une généalogie du libéralisme autoritaire. Fabrique (La). 2018

- Manhunts: A philosophical history. Princeton University Press, 2012. 
COMAROFF, J.; COMAROFF, J. The truth about crime: Sovereignty, knowledge, social order. University of Chicago Press, 2016.

- Ethnography and the historical imagination. Routledge, 2019.

COMISIÓN NACIONAL SOBRE PRISIÓN POLÍTICA Y TORTURA. Informe de

la Comisión Nacional sobre Prisión Política y Tortura (Informe Valech). Ministerio del Interior de Chile, 2005.

CONSEJO Coordinador de Seguridad Pública. Evaluación de la situación actual del terrorismo en Chile. Santiago, fevereiro de 1993.

CORTÉS, J. Estruendo. La asociación ilícita terrorista en la legislación chilena a la luz del Caso Bombas. Santiago: Libros del Perro Negro, 2013.

CUNHA, M. Malhas que a reclusão tece. Questões de identidade numa prisão feminina. Cadernos de Estudos Juidiciarios. Lisboa, 1994.

DE GIOVANANI, J. Seattle, Praga, Gênova: política anti-globalização pela experiência da ação de rua [dissertação]. São Paulo: Universidade de São Paulo, Faculdade de Filosofia, Letras e Ciências Humanas, 2008.

DEL SOLAR, F. \& PÉREZ, A. Anarquistas: presencia libertaria en Chile. RIL editores, 2008.

DELLA PORTA, D. Radicalization: A relational perspective. Annual Review of Political Science, 21, p. 461-474, 2018.

DEPUIS-DÉRI, F. Black blocs. São Paulo: Veneta, 2014.

DÍAZ, N. ¡Pablo, Eduardo y Rafael: PRESENTE!: De la memoria popular a la acción colectiva. Reconstrucción histórica del caso de la familia Vergara Toledo. Santiago (1982-2008). Ediciones Escaparate, 2010.

DÍAZ, J. Avanzada Nacional: La derecha a la derecha de Pinochet. Nuevo Mundo Mundos Nuevos, 2016.

DIDI-HUBERMAN, G. Levantes. Edições Sesc, 2017.

DINAMARCA, R. La elite de la "vieja izquierda" en las batallas de la memoria: la conmemoración del 11 de septiembre en dictadura. Izquierdas (Santiago), n. 22, p. 180-203, 2015.

DONOSO, I. Entre el dolor y la ira: la venganza de Antonio Ramón Ramón: Chile, 1914. Editorial Universidad de Los Lagos, a través del Programa de Estudios y Documentación en Ciencias Humanas, 2005.

DOVEY, K. \& FITZGERALD, J. Open court: Transparency and Legitimation in the Courthouse' IN: DOVEY, K. Becoming Places: Urbanism/Architecture/Identity/ Power, London: Routledge, 2010. 
DUPUIS-DÉRI, F. Black blocs. São Paulo: Veneta, 2014.

ECHEZARRETA, D. Lecturas de la violencia anarquista: Una crítica al expansionismo del concepto "terrorismo", Revista de Estudios Sociales Contemporáneos, 12, IMESC-IDEHESI/Conicet, Universidad Nacional De Cuyo, 2015.

ENGELS, F. Prefacio. IN: MARX, K. Las Luchas de Clases en Francia de 1848-1859. Fundación Federico Engels, 2015.

ESPINOZA, V. Local associations in Chile: social innovations in a mature neoliberal society. IN: MOULAERT, F.; MACCALLUN, D.; MEHMOOD, A.; HAMDOUCH, A. (Eds.) The International Handbook of Social Innovation. Collective Action, Social Learning and Transdisciplinary Research. Edward Elgar Publishing, 2013.

EISENZWEIG, U. Ficciones del anarquismo. México: Fondo de Cultura Económica, 2004 .

ELTIT, D. A máquina Pinochet e outros ensaios. Peixe-elétrico ensaios, 2017.

FARFÁN, C. El silencio forzado de los presos políticos en democracia. (TTC, Universidad de Chile), 2006.

FASSIN, D. The embodied past. From paranoid style to politics of memory in South Africa. Social Anthropology, 16(3), p. 312-328, 2008

FELDMAN, A. Archives of the Insensible: Of War, Photopolitics, and Dead Memory. University of Chicago Press, 2015.

FINN, J. Capturing the criminal image: From mug shot to surveillance society. U of Minnesota Press, 2009.

FONTANARI, R. A noção de punctum de Roland Barthes, uma abertura da imagem?. PARALAXE,3.1, p.61-74, 2015.

GACITÚA, D. Diseño de instrumentos de medición de la eficacia en el proceso de clasificación y segmentación de internos en unidades penales del subsistema cerrado de Gendarmería de Chile. TCC (Ingeniería Civil), Universidade do Chile, 2013.

GAGNEBIN, J. Limiar, aura e rememoração. Ensaios sobre Walter Benjamin. Editora 34, 2014 .

GARCÉS, M. Historia y memoria del 11 de septiembre de 1973 en la población La Legua de Santiago de Chile. Historizar el pasado vivo en América Latina. Santiago: Universidad Alberto Hurtado, 2007.

GENDARMERIA do Chile. Compendio Estadístico Penitenciario, 2017.

GIRARD, R. A violência e o sagrado. Paz e Terra, 2008.

GODÓI, R. Fluxos em cadeia: as prisões em São Paulo na virada dos tempos. Tese (Doutorado em Sociologia), Universidade de São Paulo, 2015. 
GOICOVIC, I. Transición y violencia política en Chile (1988-1994). Revista de Historia Contemporánea, N. 79, 2010. p. 59-86, 2010.

- Entre el dolor y la ira. La venganza de Antonio Ramón Ramón. Chile, 1914. Osorno, Editorial Universidad de los Lagos, 2005.

GODOY, E. Historia e historiografía del anarquismo en Chile (1980-2015). Cuadernos de historia (Santiago), (44), p. 101-137, 2016.

GOIDANICH, M. Configurações do corpo nas psicoses. Psicol. Soc. vol.15, n.2, p. $65-73,2003$.

GONH, M. A sociedade brasileira em movimento: vozes das ruas e seus ecos políticos e sociais. Caderno CRH, Salvador, v.27, n.7, p.431-441, 2014.

GONZÁLEZ, D. Fuego en la Cárcel de San Miguel. Santiago: Ediciones Via X, 2016.

GOODWIN, J. The Relational Approach to Terrorism. Swiss Political Science Review 15(2), p. 387-94, 2009.

GORDILLO, E. Indios Verdes. Valparaíso: Narrativa Punto Aparte, 2014.

GOULD, R. Insurgent identities: Class, community, and protest in Paris from 1848 to the Commune. University of Chicago Press, 1995.

GRAEBER, D. Direct action: an ethnography. AK Press, 2009.

GRAU, O. El encapuchamiento de la memoria. IN: RICHARD, N. Políticas y estéticas de la memoria. Editorial Cuarto Propio, 2000.

GREZ, S. Los anarquistas y el movimiento obrero: la alborada de" la Idea" en Chile, 1893-1915. Santiago: Lom Ediciones, 2007.

GUERRA, F. Prácticas anarquistas de la violencia política revolucionaria anarquista: 2004-2014. Motivos, diferencias, continuidades, particularidades en el recorrido de la insurgencia en Chile. (TCC), Universidad Academia de Humanismo Cristiano, 2015 .

GUZMÁN, N. La mujer de los perros. Santiago: Ceibo Ediciones, 2014.

HARAWAY, D. Situated knowledge: the science question in feminism and the privilege of partial perspective. Feminist Studies, Vol.14, n1, 1988.

HATHAZY, P. Democratizing Leviathan: Bureaucrats, Experts and Politics in the Transformation of the Penal State in Argentina and Chile. Tese (doutorado), UC Berkeley, 2013.

- Remaking the prisons of the market democracies: new experts, old guards and politics in the carceral fields of Argentina and Chile. Crime, Law and Social Change 65.3, p. 163-193, 2016.

HAZAN, E. A History of the Barricade. Verso Books, 2015. 
HERNÁNDEZ, R. \& SALAZAR, J. Policía de Investigaciones de Chile : 1864-1927, 1927-200o. Policía de Investigaciones de Chile. Santiago, 1994.

HOPPE, A.; PÉREZ, C. \& LÓPEZ, H. Chile 1973-1990: la dictadura de Pinochet. LOM ediciones, 2013.

INFORME CASOS BOMBAS. Informe de la Comisión Especial Investigadora acerca de las actuaciones y responsabilidades de los organismos del gobierno en el denominado "Caso Bombas”, 2012.

INFORME RETTIG, Informe de la Comisión Nacional de Verdad y Reconciliación. Vol. 1, 1991.

INSUNZA, A. \& ORTEGA, J. Los archivos del cardenal 2. Casos reales. Editorial Catalonia, 2011.

INSTITUTO NACIONAL DE DERECHOS HUMANOS. Informe Anual 2011. Situación de los Derechos Humanos en Chile. Santiago: Andros Impresores, 2011.

- Estudio de las condiciones carcelarias en Chile: Diagnóstico del cumplimiento de los estándares internacionales de Derechos Humanos sobre el derecho a la integridad personal 2016-2017. Santiago: Andros Impresores, 2011.

JASPER, J. \& THOMPSON, AK. Did Someone Say Riot? James M. Jasper in Conversation with AK Thompson, Social Movement Studies, 15:2, p. 216-230, 2016.

JENSEN, R. The international anti-anarchist conference of 1898 and the origins of Interpol. Journal of Contemporary History, 16(2), p. 323-34, 1981.

JOIGNANT, A.; DÍAZ, F. \& NAVIA, P. Diccionario de la política chilena: momios, upelientos y operadores; lugares comunes, lugares sociales y cocina política. Sudamericana, 2011.

JURIS, J. Violence performed and imagined: Militant action, the Black Bloc and the mass media in Genoa. Critique of anthropology, vol. 25, no 4, p. 413-432, 2005.

KARQUE, R. Panfletos: poniendo el grito en el cielo. Biblioteca Nacional, 2003.

KUNDNANI, A. Muslims are Coming! Islamophobia, Extremism, and the Domestic War on Terror. Verso, 2016.

LARRAÍN, J. Alegoría nostálgica de una derrota. Apuntes sobre Escuela de Guillermo Calderón. Telóndefondo Revista de Teoría y Crítica Teatral, (29), 61-75, 2019.

LEÓN, M. Una impresión imborrable de su personalidad: la fotografía carcelaria y la identificación criminológica en Chile (1870-1940). Revista Chilena de Historia del Derecho, (18), 1999. 
L'HEUILLET, H. Alta polícia, baixa política: uma abordagem histórica da policia. Tradução. Cruz Quebrada: Editorial Noticias, 2004.

LOMBROSO, C. Gli Anarchici. Fratelli Bocca, Biblioteca antropologico-Giuridica Serie ii, vol.XXIII. 1895.

OLIVER, P. \& LORENZO, C. La construcción histórica de los conceptos de "preso político" y "preso social" en la España contemporánea, 2019.

MARCUS, G. (Ed.). Paranoia within reason: A casebook on conspiracy as explanation (Vol. 6). University of Chicago Press, 1999.

MARIGHELA, C. Mini-manual del guerrillero urbano. El Cid Editor, 2009.

MARINOVIC, M. Hipótesis del terrorismo. Una metodología de análisis aplicada al caso chileno (1983-1986), ed. Instituto de Ciencia Política, Universidad de Chile, Santiago de Chile, 1987.

MARQUES, A. Humanizar e expandir: uma genealogia da segurança pública em São Paulo. Tese (doutorado), Universidade Federal de São Carlos), 2017.

MEISTER, R. After evil: A politics of human rights. Columbia University Press, 2010.

MELLA, M. Transición y democratización durante el gobierno de Patricio Aylwin (1990-1993): la estrategia de las cuerdas separadas. Revista Enfoques: Ciencia Política y Administración Pública, 12(21), 2014.

MOLINA, I. El Programa de Erradicación de Campamentos en la Región Metropolitana: Implicancias Socioeconómicas y Espaciales. Santiago. TCC (GeOGRAFIA), Universidad Católica de Chile, 1985.

MONTES, A. El cuerpo otro y los monstruos. Imaginarios del miedo y la exclusión. Amérique Latine Histoire et Mémoire. Les Cahiers ALHIM. Les Cahiers ALHIM, 2017.

MONTONI, A. Radicalisation de l'action collective et jeunesse populaire: construction du politique et résistances au Chili. Tese (doutorado em sociologia), École des Hautes Études en Sciences Sociales, 2015.

MULCAHY, L. Architects of justice: The politics of courtroom design. Social and Legal Studies, 16(3), p. 383-403, 2007.

MUÑOZ, V. El Partido Socialista de Chile y la presente cultura de facciones. Un enfoque histórico generacional (1973-2015). Izquierdas, 26, 2016.

NEOCLEOUS, M. La fabricación del orden social: una teoría crítica sobre el poder de la policía. Prometeo Libros, 2010.

NUTTALL, S. \& MBEMBE, A. Secrecy's softwares. Current Anthropology, 56(12), p. 317-324, 2015. 
ORELLANA, N. La acción contestataria en Chile a comienzos del siglo XXI: repertorio y experiencia contestatarias. Tese (doutorado). UCL-Université Catholique de Louvain, 2017.

OTANO, R. Crónica de la transición. Planeta, 1995.

OYARZO, C. La vida entre contiendas. Militancias y sentidos de la participación política en las luchas antidictatoriales de Chile y Argentina (Tese doutoral). Universidad de Santiago. Chile, 2013.

PALMA, R. El gran rescate: desflorando al viento. LOM, 2019.

PALIERAKI, E. ¡La revolución ya viene!: el MIR chileno en los años sesenta. LOM Ediciones, 2014.

PARRINI, R. El Poder, los fantasmas y los cuerpos. Políticas corporales y subjetivación en la transición chilena. Debate Feminista, 34, p. 239-258, 2006.

PASTORE, A. Jogo, ritual e teatro: um estudo antropológico do Tribunal do Júri. São Paulo: Terceiro Nome, 2012.

PAVLICH, G. The subjects of criminal identification. Punishment \& Society, 11.2, p. 171-190, 2009.

PAZ CIUDADANA. Informe Exclusión social en personas privadas de libertad, Santiago, 2015.

PEÑA, J. Los fusileros: crónica secreta de una guerrilla en Chile. Santiago: Debate, 2016.

- Jóvenes pistoleros: Violencia Política en la Transición. Santiago: Debate, 2019.

PINOCHET, A. Mensaje Presidencial, 11 de setembro de 1981.

- Mensaje Presidencial , 11 de setembro de 1983.

- Mensaje Presidencial, 11 de setembro de 1986.

POLLETTA, F. \& CALLAHAN, J. Deep stories, nostalgia narratives, and fake news: Storytelling in the Trump era. IN: MAST, J.; ALEXANDER, J. (Eds.) Politics of meaning/meaning of politics. Palgrave Macmillan, Cham, 2019.

QUIROGA, P. Desencanto, autonomía y politización. El discurso del anarquismo en la sociedad chilena post-dictadura (1990-2010) Tesis (Magíster en Historia). Universidad de Santiago de Chile, 2014.

RABINOW, P. Galton's regret and DNA typing. Culture, medicine and psychiatry, 17.1, p. 59-65, 1993.

RAMOS, M. \& GUZMÁN, J. La guerra y la paz ciudadana. LOM Ediciones, 2010. 
RAPOSO, G. Territorios de la memoria: La retórica de la calle en Villa Francia. Polis. Revista Latinoamericana, 431, 2012.

REYES, J. La autodefensa de masas y las Milicias Rodriguistas. Aprendizajes, experiencias y consolidación del trabajo militar de masas del Partido Comunista de Chile, 1982-1987. Izquierdas, no 26, 2016.

RICORDEAU, G. "Entre dedans et dehors : les parloirs” Politix, Nº 97, 2012.

RIISGAARD, L \& THOMASSEN, B. Powers of the Mask: Political Subjectivation and Rites of Participation in Local-Global Protest. Theory, Culture \& Society, 33.6, p. 75-98, 2016.

RIS $\varnothing R, H$. Civil victimhood: Citizenship, human rights and securitization in postdictatorship Chile. Anthropological Theory, 18(2-3), . 271-295, 2018.

ROCA, A. Do medo do terremoto ao medo dos outros: uma etnografia do megassimo de 2010. São Paulo: Anpocs, Co-edição com Hucitec Editora, 2016.

- O espectro criminal: entre sombras e imagens - Entrevista com Jean Comaroff e John Comaroff. Plural, 25(2), p. 182-192, 2018.

- Resenha SHOSHAN, N. 2016. The Management of Hate: Nation, Affect, and the Governance of Right-Wing Extremism in Germany. Princeton, New Jersey: Princeton University Press. 300 pp. Mana, vol. 25, no 1, p. 293-296, 2019.

ROSAS, P. Rebeldía, subversión y prisión política. Crimen y castigo en la transición chilena. Santiago: LOM, 2013

ROTH, M. Prisons and prison systems : a global encyclopedia. Greenwood Press, 2006.

SALAZAR, G. La violencia política popular en las "Grandes Alamedas". Santiago: LOM Ediciones, 2006.

SALINAS, D.; FRASER, P. Educational Opportunity and Contentious Politics: The 2011 Chilean Student Movement. Berkeley Review of Education, v.3, n.1, 2013.

SÁNCHEZ, M. La teoría de la degeneración en Chile (1892-1915). Historia (Santiago), 47(2), p. 375-400, 2014.

SANDOVAL, A. Trayectorias urbanas en el centro citadino. Hacia la construcción social del Espacio Público. Tesis (Magíster en Ciencias Sociales), Universidad de Chile, 2014.

SANTOS, J. Los centros de detención y/o tortura en Chile: Su desaparición como destino. Izquierdas (Santiago), n. 26, p. 256-275, 2016.

SILVA, R. Resistencia política y origen del movimiento social anti dictatorial en Chile (1973-1988). (Tese de Doutorado, Universitat de Barcelona), 2014. 
SILVESTRE, D. Dias de visita: uma sociologia da punição e das prisões em Itirapina. Dissertação (Mestrado em Sociologia) - Universidade Federal de São Carlos, 2011.

SOLAR, F.. Resistencia al interior de la cárcel de alta seguridad: la identidad en el Kolectivo Kamina Libre. Tese (Doutorado). Universidad Academia de Humanismo Cristiano, 2007.

SOLANO, E.; MANSO, B. \& NOVAES, W. Mascarados. A verdadeira história dos adetos da tática Black bloc. São Paulo: Geração Editorial, 2014.

SIMÉANT, J. Oh no ! Let's march but not riot!. Street protests in Bamako during the years 1992-2010, Apresentação em European Consortium for African Studies (ECAS 4), 17 junho 2011.

SÁNCHEZ, Marcelo. La teoría de la degeneración en Chile (1892-1915). Historia (Santiago), 47.2. p. 375-400, 2014.

SAAVEDRA, T. \& PROENZA, A. Fuga en Santiago: Escape desde la Cárcel Pública. Ceibo, 2015.

SHOSHAN, N. The management of hate: nation, affect, and the governance of right-wing extremism in Germany. Princeton University Press, 2016.

SOLAR, F. Resistencia al interior de la cárcel de alta seguridad: la identidad en el Kolectivo Kamina Libre. Diss. Universidad Academia de Humanismo Cristiano, 2007.

SOTO, M. Testimonio del nacimiento de mi hijo Simón Araneda. Documento Archivo Museo de la Memoria. Sem data.

STEVENSON, A. La Defensora Popular como actor político. Resistencias a la criminalización de la protesta social en Chile. Dissertação (Mestrado em Sociologia), Universidad de Chile, Santiago, 2014.

TAIT, A.; RESNIK, J. \& CURTIS, D. Constructing courts: Architecture, the ideology of judging, and the public sphere. Law, culture and visual studies. Springer Netherlands, p. 515-545, 2014.

TAMAYO, V. Imágenes y Estudios Cuantitativos en la Construcción Social de «la Juventud» Chilena: Un acercamiento histórico (2003-1967). Ultima década, vol. 12, no 20, p. 71-94, 2004.

TAMAYO, T. Caso Bombas. La explosión en la Fiscalía Sur. Santiago: LOM, 2012. 
TARROW, S. Power in Movement: Social Movements and Contentious Politics. Cambridge University, 2011.

TAUSSIG, M. History as sorcery. Representations, 7, p. 87-109, 1984.

- Walter Benjamin's grave. University of Chicago Press, 2006.

- Defacement: Public secrecy and the labor of the negative. Stanford University Press, 1999.

- Iconoclasm Dictionary. TDR/The Drama Review, 56(1), p. 10-17, 2012.

THOMPSON, A.K. Black Bloc, White Riot: Anti-globalization and the genealogy of dissent. AK Press, 2010.

TIPLER, C. \& RUSCHER, J. Agency's role in dehumanization: Non-human metaphors of out-groups. Social and Personality Psychology Compass, 8.5, p. 214-228, 2014.

TORO, P. Malas relaciones: Prensa y movimiento estudiantil universitario en chile a fines de la dictadura e inicios de la transición democrática (c. 1988-c. 1998). História da Educação, 22.54, p. 135-153, 2018.

TRAUGOTT, M. The insurgent barricade. University of California Press, 2010.

TRICOT, T. Un sociólogo en el Frente Patriótico Manuel Rodríguez. Testimonios de un militante. Santiago: Ceibo, 2015

VELHO, G. Observando o familiar. IN: NUNES (Org.) A aventura sociológica: objetividade, paixão, improviso e método na pesquisa social. Rio de Janeiro: Zahar, 1978 .

VERDUGO, P. \& HERTZ, C. Operación Siglo XX: el atentado a Pinochet. Santiago de Chile: Catalonia, 2015.

VIDAURRÁZAGA, T. Victimización y heroísmo. Disputas de las memorias emblemáticas en dos fechas conmemorativas: aniversario del Golpe de Estado y Día del Joven Combatiente. Fronteras, 1.2: p. 63-8o, 2014.

VILLEGAS, M. El terrorismo en la Constitución chilena. Revista de derecho (Valdivia), 29(2), p. 295-319, 2016.

WACQUANT, L. A tempestade global da lei e ordem: sobre punição e neoliberalismo. Rev. Sociol. Polit. [online], vol.2O, n.41, 2012.

WEIBEL, M. Los niños de la rebelión. Santiago: Aguilar, 2017.

WEIZMAN, E. Forensic architecture: Violence at the threshold of detectability. MIT Press, 2017.

WIEVIORKA, M. Violence: A new approach. Sage, 2009. 
WILSON, R. Anthropological studies of national reconciliation processes. Anthropological Theory, 3(3), p. 367-387, 2003.

WINN, P. Tejedores de la revolución: los trabajadores de Yarur y la vía chilena al socialismo. Lom ediciones, 2004 .

ZAPATA, V. Cárcel de alta seguridad: inhumanidad, represión y rebeldía. Editorial Mare Nostrum, 2005.

\section{Documentos judiciais}

Condenação “Caso Bombas”, Tercer Tribunal Oral en lo Penal de Santiago, 2011.

Condenação "Caso Caixa Eletrónico" Cuarto Tribunal Oral en lo Penal de Santiago, 2012.

Condenação “Caso Metrô” Sexto Tribunal Oral en lo Penal de Santiago, 2018.

Condenação "Caso Kevin Garrido” Sexto Tribunal Oral en lo Penal de Santiago, 2018. 